\title{
Listening to the Voice of Pachamama
}

Assessing Food Sovereignty as a Local Strategy for Community

Well-Being in Ecuador

\section{Paola Cevallos Cazar}

A 120-Point Thesis in Partial Fulfilment of Requirements for the

Degree of

Master of Development Studies

School of Geography, Environment and Earth Sciences

Victoria University of Wellington 

Bendeciré al Señor en todo tiempo; Mis labios siempre lo alabarán (Salmo 34:1 - NVI)

I will always thank the Lord; I will never stop praising Him (Psalm 34:1 - GNT) 



\section{Table of Contents}

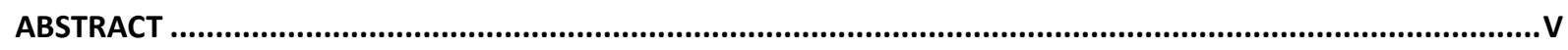

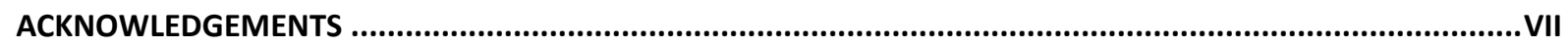

LIST OF FIGURES AND TABLES AND PLATES

GLOSSARY

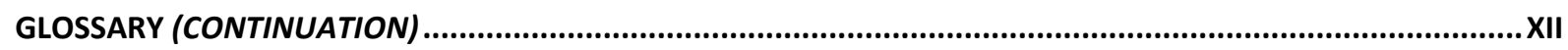

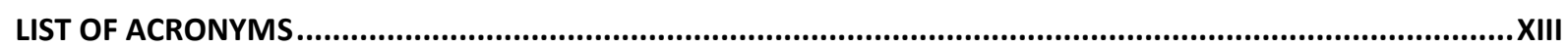

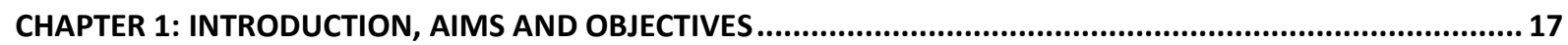

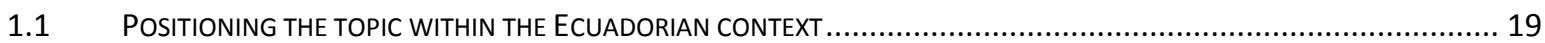

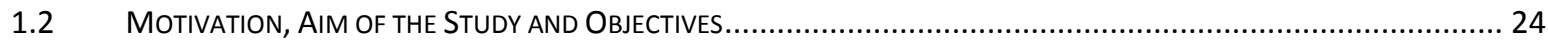

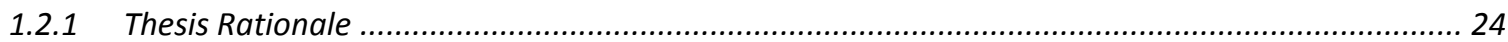

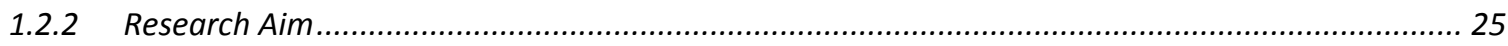

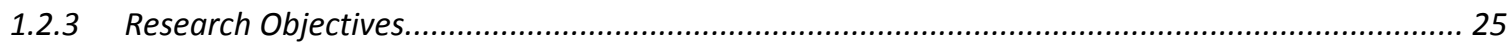

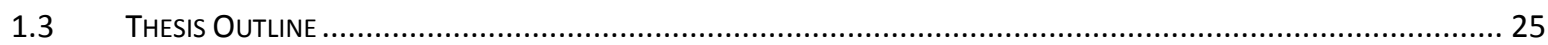

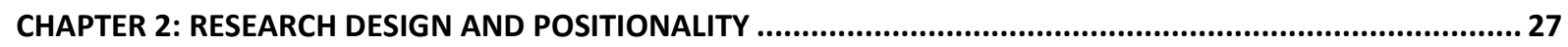

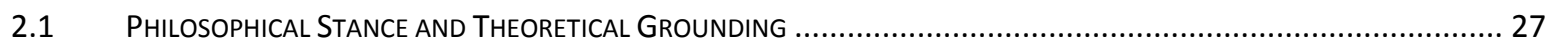

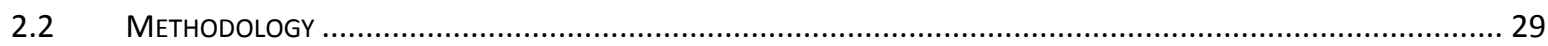

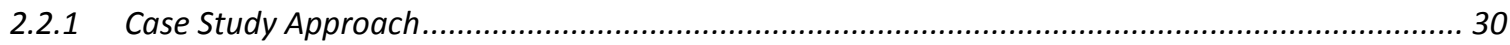

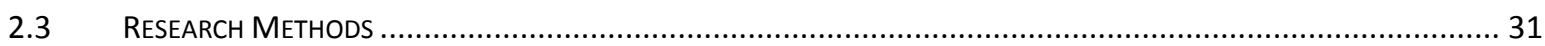

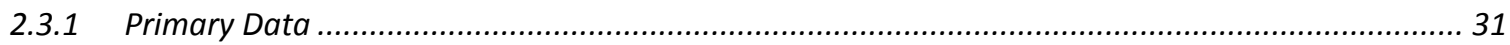

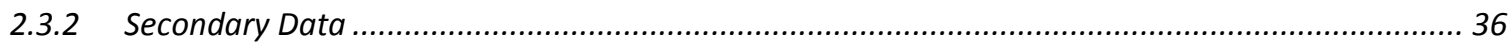

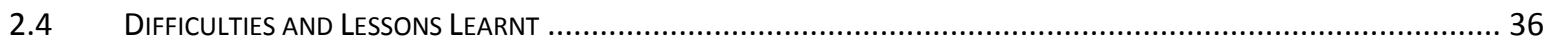

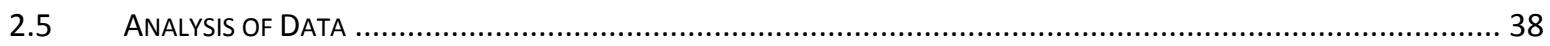

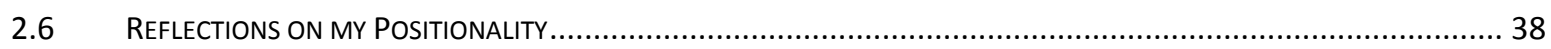

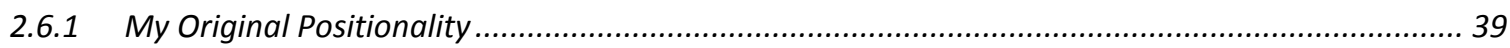

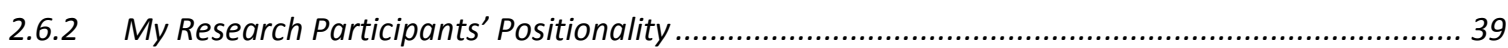

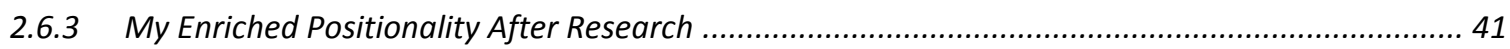

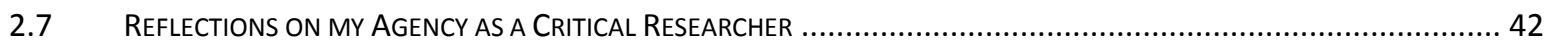

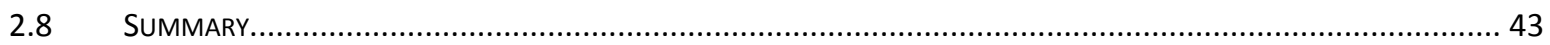

CHAPTER 3: FOOD SOVEREIGNTY AS A CONCEPT - THE CONVERGENCE OF THEORY AND PRACTICE ............... 45

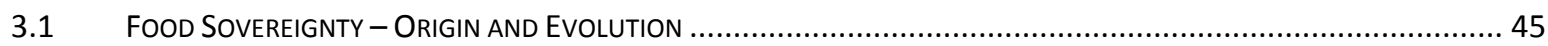

3.2 EXTRACTIVIST AGRICULTURE - IMPLICATIONS FOR COMMUNITIES AND THE ENVIRONMENT .................................. 46

3.3 ORGANIC FARMING - THE FIRST STEP FOR CHANGE

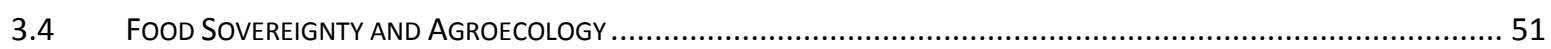

3.5 SOCIAL COHESION, POLITICAL ACTIVISM AND THE PRACTICE OF FOOD SOVEREIGNTY WORLDWIDE............................ 54

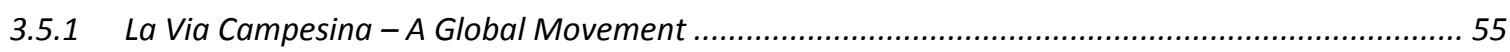

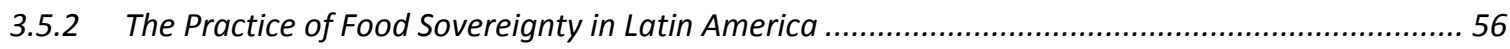

3.5.3 The Institutionalisation of Food Sovereignty in Latin America ........................................................59

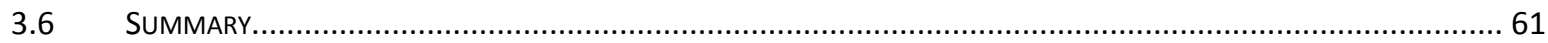




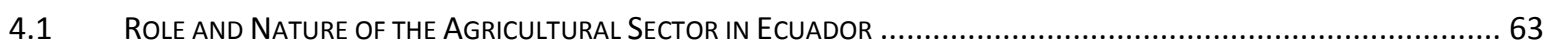

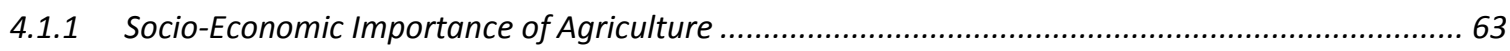

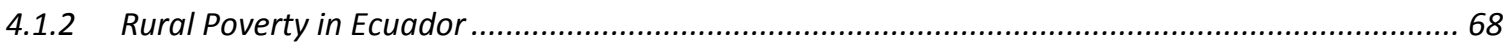

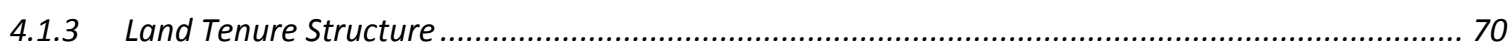

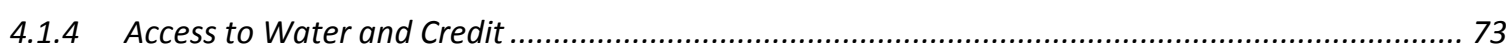

4.2 Evolution of the Peasant Struggle: Organisational Strengthening And Resilience ............................... 75

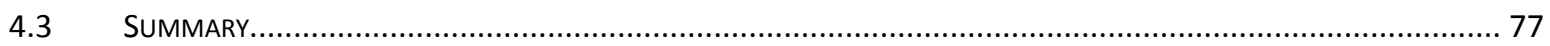

CHAPTER 5: THE GOVERNANCE OF FOOD SOVEREIGNTY IN ECUADOR ...................................................78

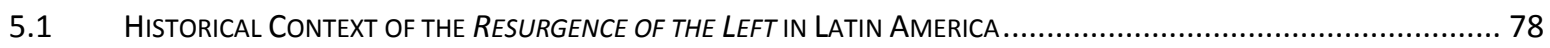

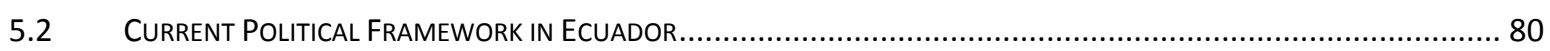

5.2.1 Political Constitution of 2008 - The Emergence of the Sumak Kawsay..........................................8 80

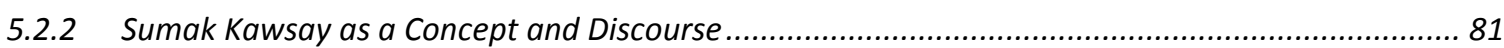

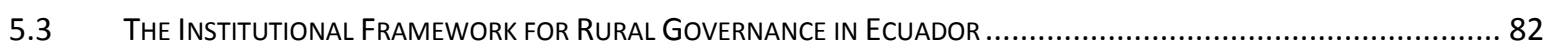

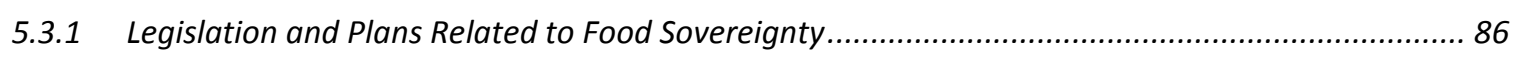

5.4 ASSESSMENT OF THE LEGAL AND INSTITUTIONAL FRAMEWORK IN ECUADOR WITH REFERENCE TO FOOd SOVEREIGNTY 89

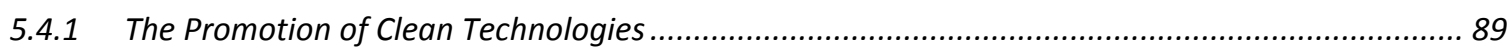

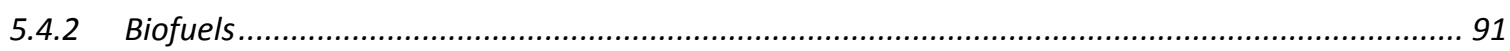

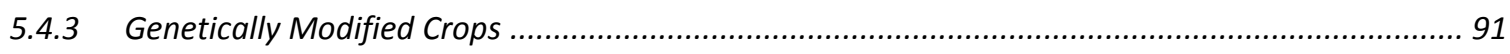

5.4.4 Policies on Availability of Productive Resources................................................................. 93

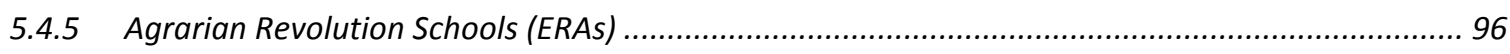

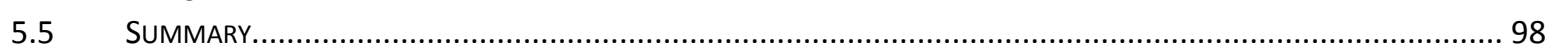

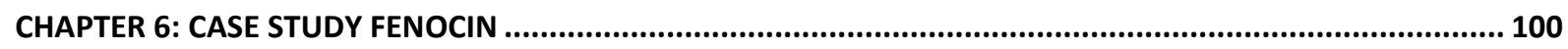

6.1 History of the Consolidation of Indigenous And PEASANt ORganisations In ECUAdor ............................... 100

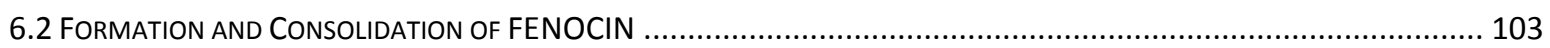

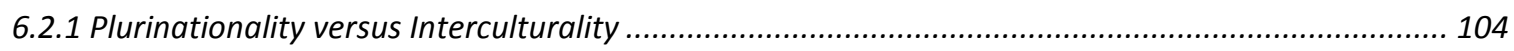

6.2.2 Structures of Representation of FENOCIN .............................................................................. 106

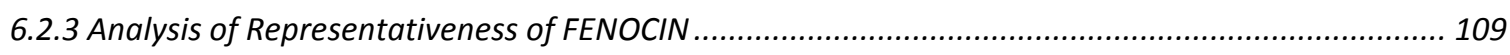

6.3 THE INSTITUTIONALISATION OF FOOD SOVEREIGNTY AND AGROECOLOGY WITHIN FENOCIN ..................................... 110

6.3.1 Conceptualisation of Food Sovereignty ........................................................................................ 110

6.3.2 Tools for the Implementation of Food Sovereignty in the Field .................................................. 111

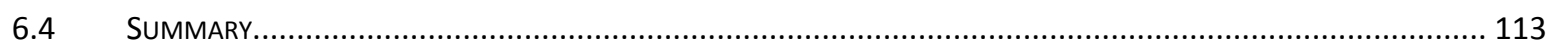

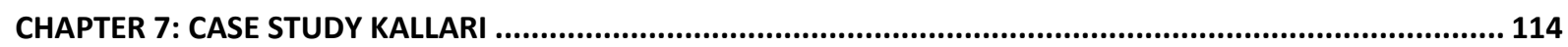

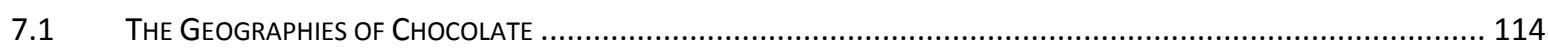

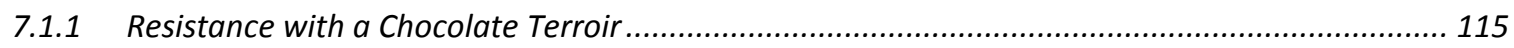

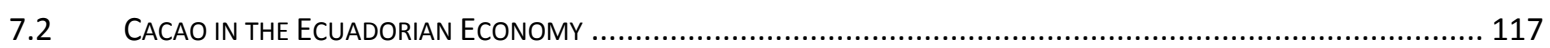

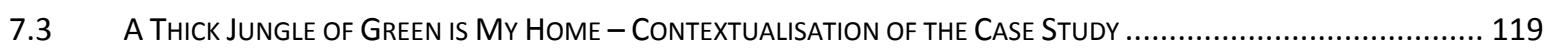

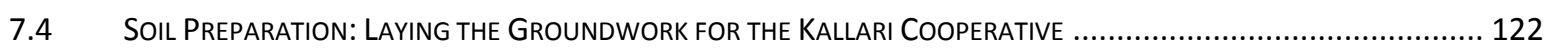

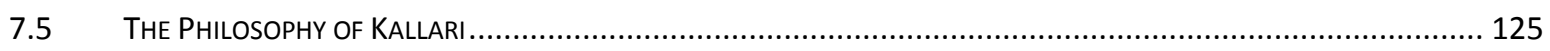

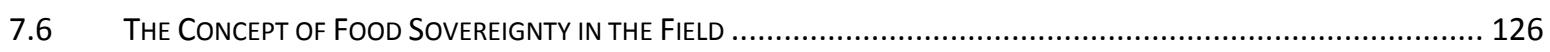

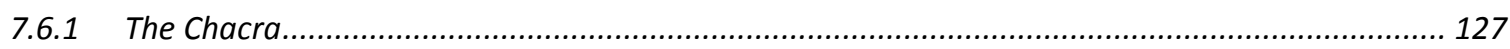

7.6.2 Agroecology in the Amazonian Rainforest Context .............................................................. 129

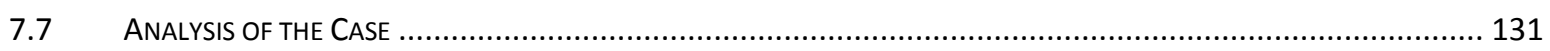

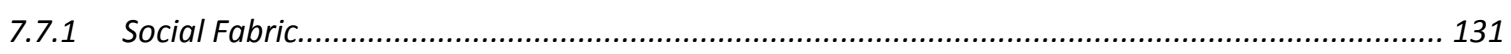

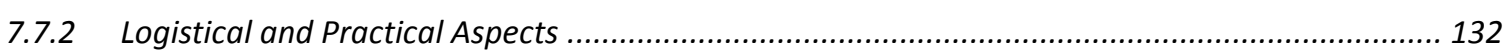

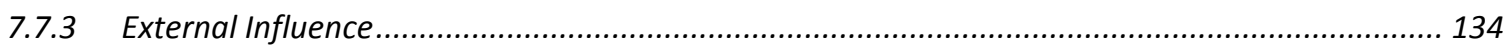




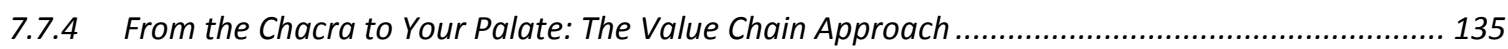

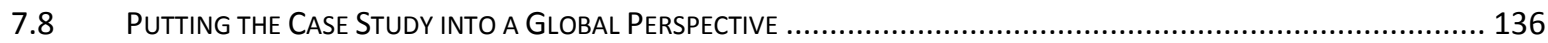

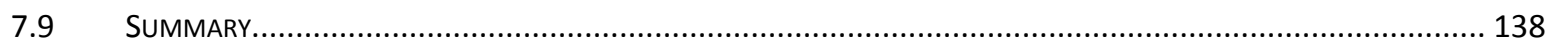

CHAPTER 8: FOOD SOVEREIGNTY, LIVELIHOODS AND GOVERNANCE - CONCLUSIONS.............................. 139

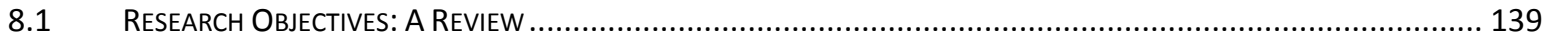

8.2 FOOD SOVEREIGNTY: TWO UNIFYING THEMES ........................................................................... 145

8.2.1 Relevance of the Practice of Food Sovereignty for the Improvement of Farming Communities'

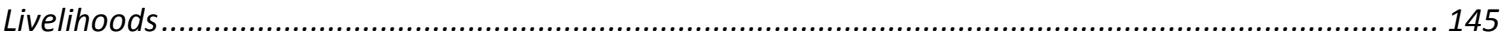

8.2.2 Resilience and Political Agency through the Practice of Food Sovereignty ................................ 151

8.3 Policy RECOMMENDATIONS FOR THE ACHIEVEMENT OF FOOD SOVEREIGNTY IN ECUAdOR................................ 156

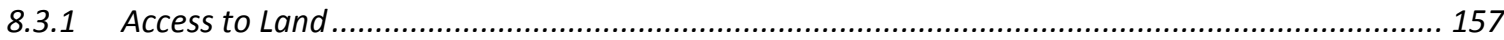

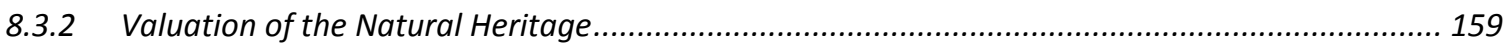

8.3.3 Permanent Platforms for Participation and Deliberation...................................................... 162

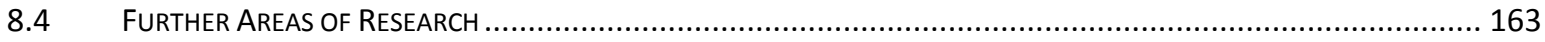

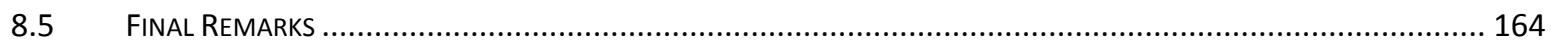

APPENDIX 1: DOCUMENTATION RELATED TO THE VICTORIA UNIVERSITY'S HUMAN ETHICS APPROVAL ..... 166

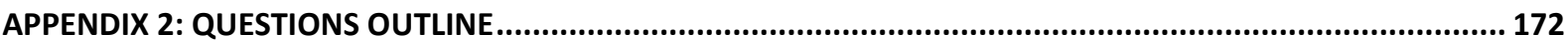

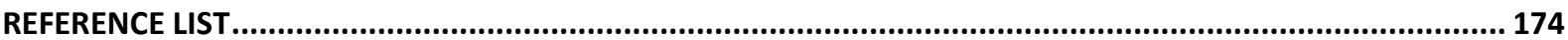




\begin{abstract}
This thesis explores how the concepts of food sovereignty and agroecology have been adopted in Ecuador, and evaluates their potential to contribute to farming communities' wellbeing. It draws on the perceptions of civil society and grassroots movements. Consequently, this study has adopted a multiple case study approach. The first case study analyses the formation and consolidation into a single movement of a federation of peasant movements that pursue food sovereignty as one of their main objectives. The way in which food sovereignty has been institutionalised within the movement is elucidated, in order to examine the strategies put into place by the social apparatus. The second case study carefully examines a community undertaking that has successfully applied the principles of food sovereignty, while improving the farmers' livelihoods. This case study elaborates on the specific characteristics inherent in the practice of food sovereignty and agroecology in the field, and intertwines this information with the culture and philosophy of the community involved. In order to identify the potentiality of replication, the community undertaking is put into global perspective through a comparative analysis that allows the identification of local and global influences that can make such an initiative successful. Acknowledging that food sovereignty is a holistic and complex concept, and that appropriate frameworks need to be established, this study has scrutinised the current governance framework in Ecuador, and consequently suggested policy recommendations that would support the widespread practice of food sovereignty and agroecology. Two aspects beyond the research objectives have emerged: firstly, the potential of the food sovereignty approach for the improvement of farmers' livelihoods; and secondly, the political significance of the concept, manifested through resistance and resilience at the grassroots level.
\end{abstract}

Key Words: Food sovereignty, food security, agroecology, extractivist agriculture, traditional ecological knowledge, holistic well-being, rural sustainable development, case study approach, community undertaking. 


\section{Acknowledgements}

To my research participants, thank you for your openness, cooperation and the time you have invested in this project. Every conversation, field visit and community gathering was invaluable for both my personal and academic experience.

To my supervisor, Warwick Murray, who had an amazing ability to discern the best way to harmonise all the information available, while not losing awareness of the big picture. You were also very insightful, supportive and encouraging.

To the NZAID programme, thank you so much for making it possible for me to undertake this Masters Programme. A very special thanks to my NZAID Scholarship coordinators, Julia Harrison and Linsell Richards, as well as to the whole team, who were always available and ready to help. You cannot imagine how precious your support and encouragement throughout the whole process was, and how important it is for foreign students to have the support network that you have beautifully put into place.

To my friends in New Zealand, Ecuador and elsewhere, who would always check on me, especially during periods when I was immersed in my thesis. Your friendship, every email sent and moment spent together were invaluable to me. Special thanks to my office and other Uni mates, Spanish-lunch friends, lifegroup friends, church friends, Tongariro-Alpine Crossing friends, and flatmates. Thanks so much to Carolyn, Cat, Amy, Lore, Kathryn, Pete and Beth Thomas for your encouragement and support. Special thanks to Andrew Rae for helping me out with the maps.

To my family, but particularly my mum. Thanks for being such a wonderful and supportive mother. After God, I owe all I am to you. Your dedication, love and strength have been an inspiration every day of my life. I have no words to express how much I love, respect and admire you. And to Scotty, my friend and my love, thanks for all your love, patience and support during this busy period of time. I love you so much and feel so blessed to have you in my life. 


\section{List of Figures and Tables and Plates}

\section{List of Figures}

Figure 1.1: Political Map of Ecuador

Figure 1.2: Land Tenure Structure, Percentage of Land Accounted for by Land Holding Size Categories (Land Holding Measured in APU) ........................................... 22

Figure 1.3: Child Malnutrition in Ecuador, by Ethnicity and Region (2008)................... 23

Figure 2.1: Political Map of Ecuador Showing Provinces Visited During Field Research ........ 32

Figure 4.1: Evolution in the Participation of Agriculture, Manufacturing and Mining in total GDP $(1950$ - 2007)....

Figure 4.2: Rural Poverty in Ecuador - Consumption, Unsatisfied Basic Needs (UBN) and Income Methods

Figure 4.3: Urban Versus Rural Poverty - Income Method................................. 70

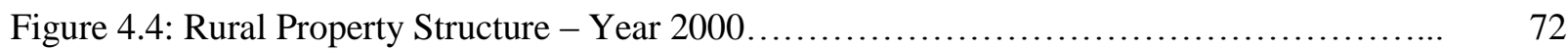

Figure 5.1: National and Sub-National Dynamics - Vertical Coordination...................... 83

Figure 5.2: The Executive Power at the National Level - Horizontal Coordination ............... 85

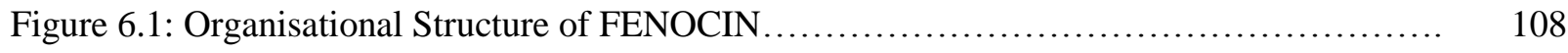

Figure 7.1: Political-Administrative Map of the Province of Napo............................ 120

\section{List of Tables}

Table 2.1 - Regions and Provinces Visited During Field Research.......................... 32

Table 2.2: Research Participants...................................................... 33

Table 3.1: Comparison of Extractivist Agriculture and the Food Sovereignty Approach........... 48

Table 4.1: Composition of Gross Domestic Product (GDP) at Market Prices ...................... 64

Table 4.2: Participation of Agriculture, Oil and Mining, Petroleum Refining and Manufacturing in Ecuador's GDP, According to the Central Bank of Ecuador $(2000-2011)$............................. 66

Table 4.3: Structure of Land Tenure in Rural Areas of Ecuador............................. 71

Table 4.4: Funding Structure for Farming Activities......................................... 74

Table 6.1: Historic Milestones in the Consolidation of Indigenous and Peasant Movements in

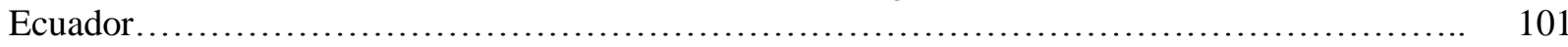

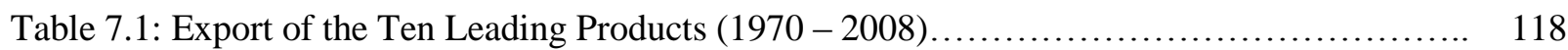

\section{List of Plates}

Plate 5.1: Babaco greenhouse nursery for monoculture plantation - Field visit ERA, Province of Loja, June, 2012.

Plate 6.1: Field visit chacra Association Alcaluna. Toacaso, Province of Cotopaxi

Plate 6.2: Field visit chacra Association Alcaluna. Toacaso, Province of Cotopaxi

Plate 7.1: Chacra in the Amazonian rainforest, at the beginning of the planting season.

Archidona, Province of Napo.

Plate 7.2: From left to right: Witch Broom; Monilia; Uncontaminated Cacao Fruit. Archidona, Province of Napo. 


\section{Glossary}

\section{Terms in English}

Monilia

Witch Broom

\section{Terms in Kichwa}

Alli Kawsay

Ayllu

Chacra

Chicha

Cuy

Huasipungo

Kallari

Kichwa

Pachamama

Sumak Kawsay
Cacao disease caused by a fungus

Cacao disease that causes a deformity in the plant
Good in Life

Ayllu refers to self-sustaining indigenous family networks that function through reciprocity and kinship, in commonly held lands

Swidden-based orchards

Indigenous andean beverage

Guinea pig

Huasipungo was a piece of land that mestizos or Spanish gave to indigenous people for their agricultural and pastoral work. It was the institutionalisation of oppression over indigenous ethnic groups from the Sierra.

Cooperative of Cacao-Chocolate Producers

Indigenous language or Nationality

Mother Nature *

Madre Tierra*

Good Living *

'Holistic Well-being' or 'Life in Fullness'

Buen Vivir (Spanish)

Suma Qamaña (Indigenous language Aymara)

* Refers to terms which have a different connotation in Spanish or English, and accordingly will be analysed in depth throughout this dissertation 


\section{Glossary (continuation)}

\section{Terms in Spanish}

Alianza País

Campesino

FARC

La Via

Campesina

Campesino

Montubio

Negro

Revolucion

Ciudadana

Sendero

Luminoso
Political movement of the current President of Ecuador. Can be translated to English as 'Partnership for the Country'

Peasant or traditional, mostly small-scale farmer

Peasant guerrilla with a political platform (Colombia)

The Peasants' Way

Peasant or traditional, mostly small-scale farmer

Peasants or campesinos from the Coastal region of Ecuador

People of African descent

Slogan of the 'Alianza País' political movement. Can be translated to English as 'The Citizens' Revolution'

Maoist guerrilla (Peru) 


\section{List of Acronyms}

\section{English}

APU

BAU

BCE

BNF

CAN

CBD

CEDOC

CEOLS

CEPALSTAT

CLOC

CONAIE

COOTAD

COPISA

CTE

EA

ECLAC

ECUARUNARI

ERAs
Agricultural Production Unit

Business As Usual

Central Bank of Ecuador

National Development Bank

Andean Community

Convention on Biological

Diversity

Ecuadorian Confederation of Catholic Workers

Ecuadorian Confederation of Free Unions

Data Base of ECLAC

Latin American Coordinator of Rural Organizations

The Confederation of Indigenous Nationalities of Ecuador

Organic Code of Territorial Organisation, Autonomy and Decentralisation

Plurinational and Intercultural Conference on Food Sovereignty

Ecuadorian Confederation of Workers

Extractivist Agriculture

Economic Commission for Latin America and the Caribbean

Kichwa Confederation of Ecuador

Agrarian Revolution Schools

\section{Spanish}

Unidad Productiva

Agropecuaria

Como de Costumbre/Igual que Siempre

Banco Central del Ecuador

Banco Nacional de Fomento

Comunidad Andina de

Naciones

Convenio sobre la

Diversidad Biológica

Confederación Ecuatoriana de Obreros Católicos

Confederación Ecuatoriana de Organizaciones Libres Sindicales

Base de Datos de la CEPAL

Coordinadora

Latinoamericana de Organizaciones del Campo

Confederación de

Nacionalidades Indígenas del Ecuador

Código Orgánico de

Organización Territorial, Autonomía y

Descentralización

Conferencia Plurinacional e Intercultural de Soberanía Alimentaria

Confederación de Trabajadores Ecuatorianos

Agricultura Extractivista

Comisión Económica para Latinoamérica y el Caribe (CEPAL)

Confederación Kichwa del Ecuador

Escuelas de la Revolución Agraria 


\section{List of Acronyms (continuation)}

\section{English}

FARC

FEI

FENOC

FENOC-I

FENOCIN

FETAP

FS

FUC

GDP

GM crops

GVA

HYV

IFOAM

INEC
Revolutionary Armed Forces

of Colombia

Federation of Agricultural

Centres and Coastal Rural

Organisations

Ecuadorian Federation of Indians

National Federation of Peasant Organisations

National Federation of

Peasant and Indigenous

Organisations

National Federation of

Peasant, Indigenous and

Black Organisations

Ecuadorian Federation of Agricultural Workers

Food Sovereignty

Classist Unity Front

Gross Domestic Product

Genetically Modified Crops

Gross Value Added

High-Yielding Variety

International Federation of

Organic Agriculture

Movements

National Institute of

Statistics and Censuses of

Ecuador

\section{Spanish}

Fuerzas Armadas

Revolucionarias de Colombia

Federación de Centros

Agrícolas y Organizaciones

Campesinas del Litoral

Federación Ecuatoriana de Indios

Federación Nacional de Organizaciones Campesinas

Federación Nacional de Organizaciones Campesinas

Confederación Nacional de Organizaciones Campesinas, Indígenas y Negras

Federación Ecuatoriana de Trabajadores Agropecuarios

Soberanía Alimentaria

Frente de Unidad Clasista

Producto Interno Bruto

Cultivos Transgénicos

Valor Añadido Bruto

Variedad de Alto

Rendimiento

Federación Internacional de Movimientos de Agricultura Orgánica

Instituto Nacional de

Estadisticas y Censos 


\section{List of Acronyms (continuation)}

\section{English}

\begin{tabular}{|c|c|}
\hline INIAP & $\begin{array}{l}\text { National Autonomous } \\
\text { Institute for Agricultural } \\
\text { Research }\end{array}$ \\
\hline ISEW & $\begin{array}{l}\text { Sustainable Economic } \\
\text { Welfare indicator(s) }\end{array}$ \\
\hline LORSA & $\begin{array}{l}\text { Organic Law of Food } \\
\text { Sovereignty }\end{array}$ \\
\hline MAELA & $\begin{array}{l}\text { Agroecology Movement for } \\
\text { Latin America and the } \\
\text { Caribbean }\end{array}$ \\
\hline MAGAP & $\begin{array}{l}\text { Ministry of Agriculture, } \\
\text { Livestock, Aquaculture and } \\
\text { Fisheries }\end{array}$ \\
\hline NGO & $\begin{array}{l}\text { Non-governmental } \\
\text { Organisation }\end{array}$ \\
\hline PAR & $\begin{array}{l}\text { Participatory Action } \\
\text { Research }\end{array}$ \\
\hline SA & $\begin{array}{l}\text { Structural Adjustment } \\
\text { Programmes }\end{array}$ \\
\hline
\end{tabular}

SENPLADES National Planning Secretariat

SISSAN Information System for Food and Nutrition

SOCLA

TEEB

UBN

UNESCO

MST
Latin American Scientific

Society of Agroecology

Economics of Ecosystems and Biodiversity

Unsatisfied Basic Needs

United Nations Educational, Scientific and Cultural

Organization

Movement of Landless Rural Workers

\section{Spanish}

Instituto Nacional Autónomo de Investigaciones

Agropecuarias

Indicador(es) de Bienestar

Económico Sostenible

Ley Orgánica del Régimen de Soberanía Alimentaria

Movimiento Agroecológico

para Latinoamérica y El

Caribe

Ministerio de Agricultura,

Ganadería, Acuacultura y

Pesca

Organización No-

Gubernamental

Investigación de Acción

Participativa

Programas de Ajuste

Estructural (PAE)

Secretaría Nacional de Planificación y Desarrollo

Sistema de Indicadores Sociales para la Nutrición, y Seguridad y Soberanía Alimentaria

Sociedad Científica Latinoamericana de Agroecología

Economía de los Ecosistemas y la Biodiversidad

Necesidades Básicas Insatisfechas

Organización de las Naciones Unidas para la Educación, la Ciencia y la Cultura

Movimento dos Trabalhadores Rurais Sem Terra (Portugese) 


\section{Chapter 1}

\section{Introduction, Aims and Objectives}

When I embarked upon this venture of pursuing a Masters degree in New Zealand, far away from Latin America, I was full of expectations relating to how my chosen study major, Development Studies, would be relevant to my home country, Ecuador. Like many other Latin developing countries, Ecuador, as beautiful and resourceful as it is, faces great inequality, land dispossession, poverty and all the interconnected matters that the former encompasses. I intended to study something that could contribute to a positive change. After reflecting on the various aspects of development, I found the sharp difference of conditions and opportunities between rural and urban areas very interesting. In this way, my wide and disperse interests started to lead me towards Ecuadorian rural dynamics. As a mestiza, ${ }^{1}$ middle-class woman, brought up in Quito - the capital city - I knew very little about the real challenges which communities in the rural areas face, and what exactly academia or the State could do for them.

Paradoxically, I felt close to them in my empathy with their situation, but considerably distant regarding a real understanding of their lives and needs. Economic reliance on mineral extraction and the agro-export industry narrowed down the prospects of study, as both topics are linked to the effects of the conventional path to 'development'. After surveying relevant information and becoming more acquainted with the agricultural sector in Ecuador, I was exposed to a new, fascinating and still largely unexplored concept: food sovereignty. I had heard about food security and momentarily thought that both concepts were similar, but I soon realised that the concept of food sovereignty differs greatly from food security. Fears of letting people starve triggered the formation of the concept of food security, which is concerned with satisfying minimum caloric needs. Whereas cultural awareness and self-

\footnotetext{
${ }^{1}$ The Mestizo ethnicity stems from the mixture of Spanish and Indigenous people from Latin America. After the Spanish colonisation, a new culture emerged: the Mestizos. But after more than 500 years of colonisation, mestizo is a culture and ethnicity in its own right. This means that I cannot identify myself as Spanish or Indigenous, but as Mestiza.
} 
determination, among others, were the preamble of food sovereignty, which goes beyond the simplistic conception of food as a biological need, and implies culturally-appropriate and sustainable food, taking into account the environmental, economic, political and sociocultural implications for communities. A short explanation of these implications in the various arenas follows (Cevallos Cazar, 2012b). ${ }^{2}$

The environmental arena involves consideration of the characteristics of the ecosystem in a given location, so that production practices preserve biodiversity and the ecological balance. This is achieved through the use of organic inputs, crop rotation and intercropping, agroforestry and the application of new technologies in conjunction with indigenous and traditional knowledge. With this approach pests are naturally controlled and the soil maintains and boosts its nutrients, allowing future generations to have access to clean and nutritious food, while preserving and respecting their habitat. The impacts on the environment of massive extractivist agriculture are much more problematic than what most of us are aware of: the poisoning of fresh water sources, abolition of a wide range of crop varieties in favour of monocultures, soil depletion, felling of forests, desertification and, in some cases, endangerment of native communities.

The economic arena implies a trading strategy based on local markets, fair prices and a direct relationship between consumer and producer, so as to allow the economic and financial resources to benefit the farming community.

The concept of food sovereignty involves a political arena, for it is not possible to achieve food sovereignty without challenging the current production structure. With the practice of food sovereignty on a small scale, a new form of empowerment arises, so as to pursue deep changes in the dominant structures that have maintained farming communities under the oppression and subordination to the middleman, supermarket chains and the extractivist agroexport approach.

\footnotetext{
${ }^{2}$ This section has been taken from a blog post that I wrote on the 17 September 2012, for the Social Justice Week blog, facilitated by the NGO Caritas New Zealand.
} 
Finally, the socio-cultural arena involves having access to culturally-appropriate food through the management of productive resources (water, land and credit), as well as the influence on land planning and policy formulation. This also relates to the ability of communities to maintain their traditional customs and to choose their own development path, which deeply considers their values and the way in which they relate to Pachamama (or Mother Nature). It is worthwhile noting that the connotation and implications of the term Pachamama, in Kichwa, go beyond the western conception of Mother Nature, in English, or Madre Tierra, in Spanish. Pachamama represents a deep connection of mainly indigenous communities and farmers, with the soil, flora and fauna, according to their particular worldview, which is imbued by a deep respect to nature. This is expressed through personifications of their surrounding environment. A more in depth exploration of this aspect, in the particular case of my research participants, is offered in Chapter 2. As the relation between farming and indigenous communities with the Pachamama is highly related to their specific values and worldviews, this dissertation will delve into the voices of the research participants, and through them, it will attempt to listen to the voice of Pachamama.

\subsection{Positioning the topic within the Ecuadorian context}

Ecuador is a country in South America, with a population of $14,483,499$ people (INEC, 2010), within an area of $283,560 \mathrm{~km}^{2}$. It is divided into four regions: the Galapagos Islands (Galapagos), the Sierra region (Sierra), the Coastal region (Coast) and the Amazonian region. Figure 1.1 presents a map of Ecuador, outlining the different provinces and regions. The Galapagos Islands are located in the Pacific Ocean at about 1,000 km from the Ecuadorian coast. There are 13 big islands, 5 small islands and about 105 islets, formed as a result of intensive volcanic activity. The Galapagos were among the first group of sites designated as World Heritage in 1978 by the United Nations Educational, Scientific and Cultural Organization (UNESCO), due to their unique biodiversity and importance to the conservation of endemic species of flora and fauna. The Coast is characterised by tropical warm weather. There are several beaches along the coastline, and a high diversity and biodiversity. The mass production of bananas takes place in this region. Indigenous groups are a minority on the Coast. 


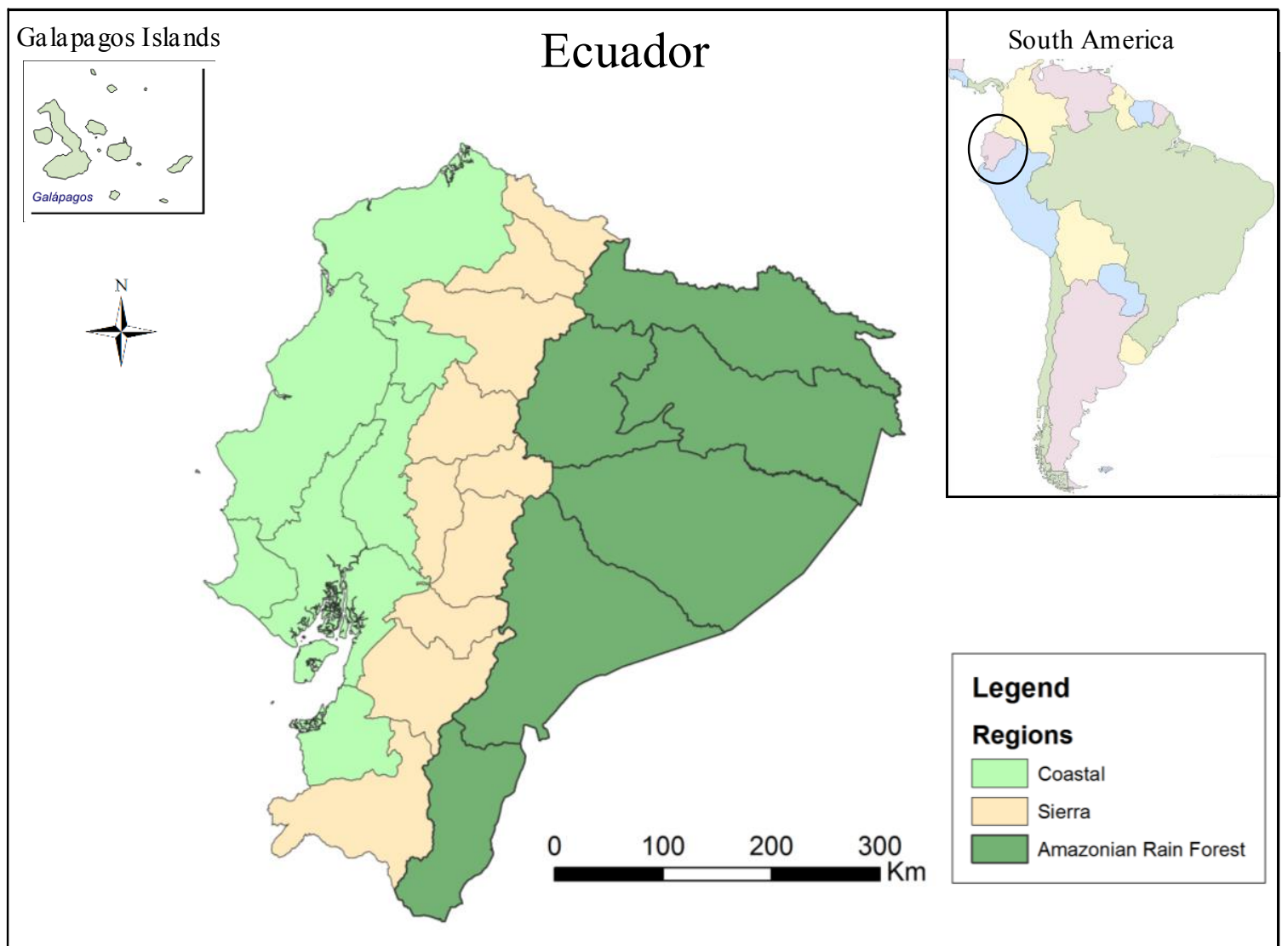

Elaboration: Andrew Rae and Author

Sources: D-maps (n.d.-a); D-maps (n.d.-b); and, Souris (n.d.)

The Sierra region consists of highlands and lowlands, therefore the climate in this region can be warm, mild or cold. The flora and fauna found in this region are rich and diverse, but also different from the Coastal, Amazonian or Insular regions. The dominant ethnic group, after the mestizos, are the Kichwa indigenous people. The Amazonian region has several protected areas, one of them, the Yasuní National Park has been identified as one of the "most biodiverse places on earth" (Bass et al., 2010, p. 1). There is a high diversity of ethnic groups in the Amazon, two of them, the Tagaeri and Taromenane, are the last indigenous communities that live in voluntary isolation (Yasuni-ITT, n.d.).

\section{Is there food sovereignty in Ecuador?}

There has been much discussion and writing about the difficult conditions of the rural areas in Ecuador (Araujo, 2006; Bravo, 2009; Larrea, et al., 2008; Larrea, 2010; Martínez, 2005). In fact, despite being one of the "twelve mega-diverse countries in the world, having 46 different 
types of ecosystems, and being ranked number one in the world as the country with the greatest number of vertebrates per unit area" (Coffey, et al., 2007, p. 15, author's translation), a large portion of this natural richness has been destroyed, or at least degraded, through extractive activities of renewable and non-renewable resource development. Much of the land that was previously owned by communities and indigenous peoples is currently being exploited by large agro-export companies, often under the ideology of the Green Revolution (Herrera, 2009). The inequality between the urban and rural areas has become more acute during the last 40 years, and the inequality within rural areas has followed the same trend (Carrión \& Herrera, 2012; Chiriboga \& Wallis, 2010). One of the most negative factors that accentuates these inequalities is the concentration of land. Figure 1.2 presents the land tenure structure in Ecuador, according to number and size of Agricultural Production Units (APU). The Ecuadorian Institute of Statistics defines an APU as a property of $500 \mathrm{~m}^{2}$ or more, where agricultural activities are conducted (with a total or partial use of the land). Properties under $500 \mathrm{~m}^{2}$ are also considered APUs if some of their production is commercialised. 
Figure 1.2: Land Tenure Structure, Percentage of Land Accounted for by Land Holding Size Categories (Land Holding Measured in APU)

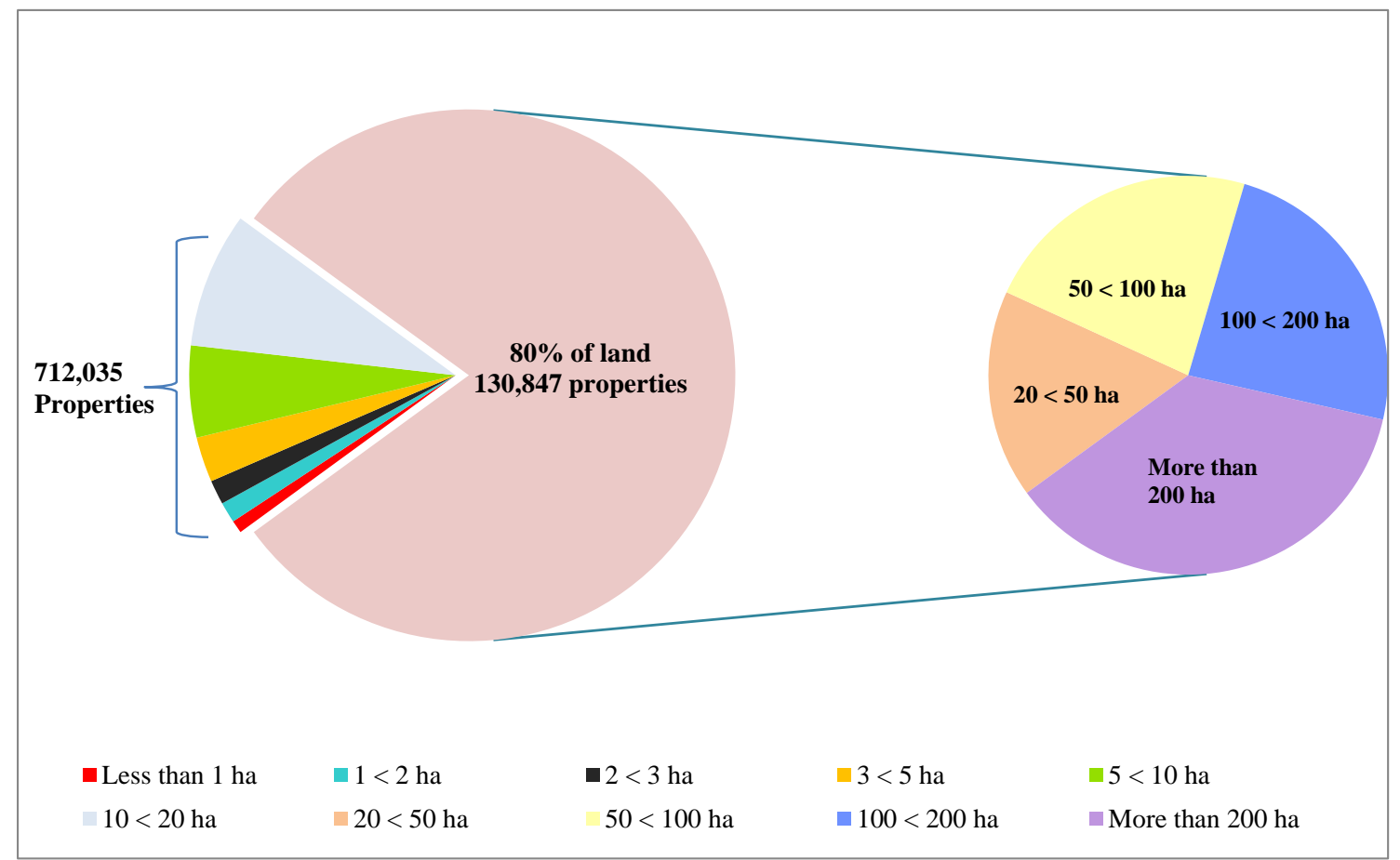

Elaboration: Author

Source: INEC (2000)

As it can be noted, there is a large concentration of rural properties: $80 \%$ of the total land is in the hands of only $16 \%$ of the owners (or 130,847 APUs). In contrast, $85 \%$ of all APUs (around 712,000 properties) produce on only 20\% of the land. This situation leaves thousands of peasant families with access to very small land slots, or no land access at all, condemning them to poverty and malnutrition. According to Chiriboga and Wallis (2010) the levels of poverty in year 2006, in terms of consumption, were more acute in the Amazonian region: around $60 \%$ of prevalence. In the same year, levels of poverty in the Coast and Sierra were $40 \%$ and $34 \%$ respectively. Figure 1.3 displays child malnutrition, by ethnicity and region. 
Figure 1.3: Child Malnutrition in Ecuador, by Ethnicity and Region (2008)

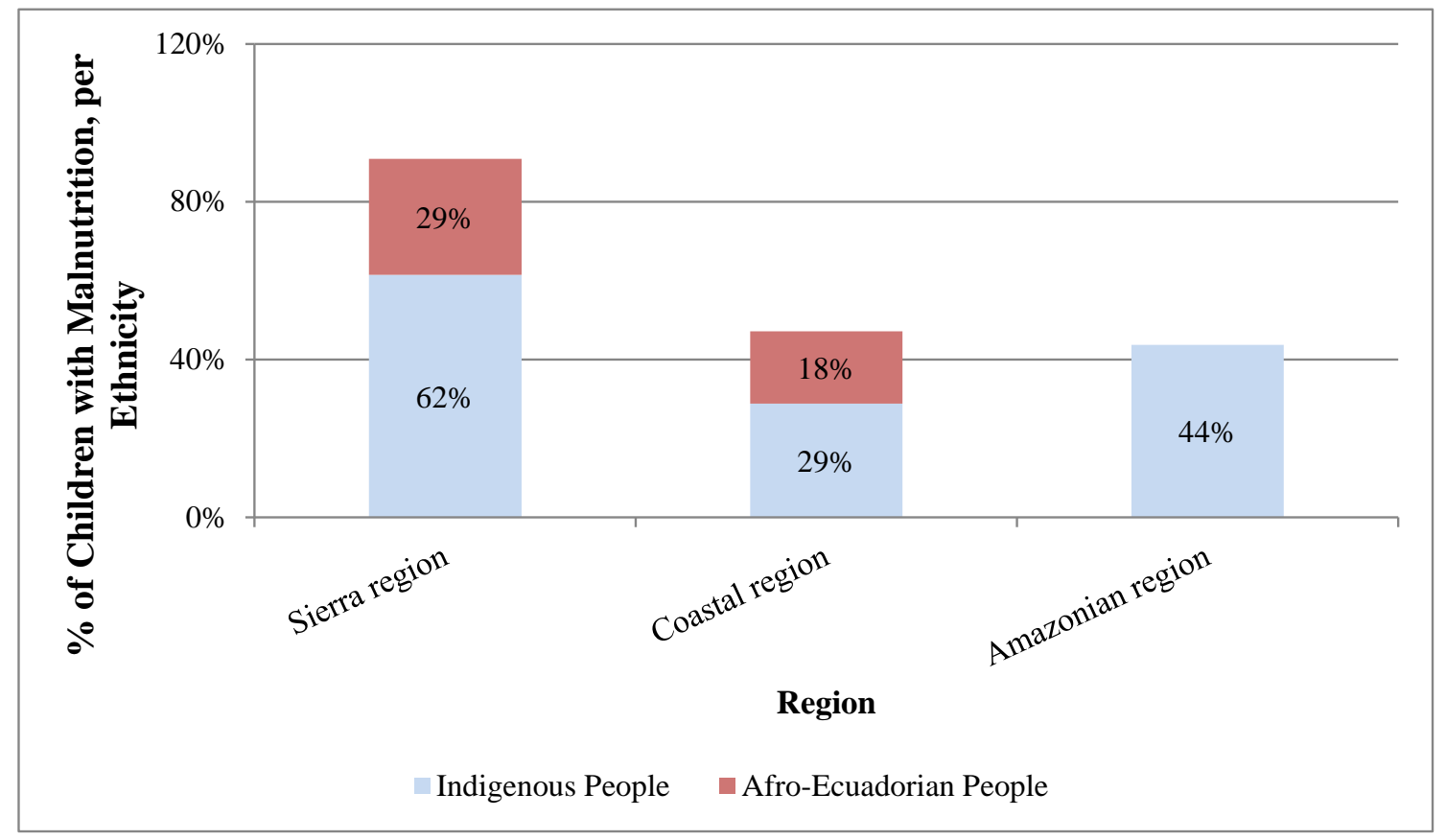

Elaboration: Author

Source: INEC (2008)

As seen above, incidence of child malnutrition and poverty among indigenous people is more acute in the Sierra: $62 \%$ of total malnourished children belong to the indigenous group. In 2001, the Sierra region had the highest indigenous population: around 580,000 people, which represents $78 \%$ of that ethnic group within the country (INEC, 2001, 2008). The level of child malnutrition for the indigenous ethnicity in the Amazonian region is also very high, at $44 \%$. In the case of Afro-Ecuadorians, it can be noted that the incidence of poverty in the Sierra region corresponds to $29 \%$ and in the Coastal region to $18 \%$. It follows that child malnutrition is more acute for the indigenous ethnicity overall. The unstable, detrimental and disadvantageous work conditions imposed mainly on indigenous people and farming communities have neglected their self-determination, perpetuating their poverty levels and worsening levels of poverty and malnutrition (Larrea, 2008). 


\subsection{Motivation, Aim of the Study and Objectives}

\subsubsection{Thesis Rationale}

My fondness for development studies, as an interdisciplinary field, was based on the possibility of being able to contribute, in a tangible way, to address the marked differences between classes and ethnic groups in my country. This dissertation seeks to contribute to a deeper understanding of the concept of food sovereignty and its implications for the wider community and farmers, within the particular context of Ecuador. This will be achieved through the exploration of the concept of food sovereignty in theory and practice, so as to understand the realities of family farming in the country. Preference will be given to the views of communities and social movements, through ample field research, so as to give them voice and, through their voice, identify challenges for the authorities, policymakers and society. Policy recommendations and the identification of further areas of study will be drawn from the analysis. This work, with the joint efforts of academia, social movements, diverse sectors of civil society, and government institutions could contribute to the identification of an agenda for change. The evidence shows that the practice of the principles of food sovereignty in Ecuador could not only address malnutrition problems, but could hopefully enable indigenous and traditional farming communities to pursue more holistic and sustainable rural development.

Disenchantment with the Structural Adjustment Programmes (SAP) implemented in the Latin American region during the 1970s, 1980s and 1990s and the neoliberal trend manifested through market-oriented policies led to the emergence of political leaders with a left wing discourse. Accordingly, a new political phenomenon can be observed in the region: Twentyfirst Century Socialism has been coined as a progressive, revolutionary approach that would challenge the structures in place, and pursue social equality. The Twenty-first Century Socialism and the Good Living approach are part of the current political discourse in Ecuador. Moreover, in the last four years, legislation has been approved in relation to food sovereignty. In light of the aforementioned, the political climate in Ecuador seems to be the most appropriate for exploring the civil society perspectives on food sovereignty. 


\subsubsection{Research Aim}

The aim of this study is to analyse how the concept of food sovereignty has been adopted in Ecuador. This will be achieved through assessing if food sovereignty is a valid way for farming communities to contribute to the improvement of their well-being.

\subsubsection{Research Objectives}

1. To understand how the concept of food sovereignty has been formed and has evolved over time, with a focus on Latin America and Ecuador.

2. To assess the policies and governance framework relevant to food sovereignty that the Ecuadorian government put in place between 2006 and mid-2012.

3. To analyse how civil society relates to food sovereignty and how grassroots movements have exerted agency as an answer to the conditions imposed on the agro-sector, through a case study.

4. To identify how the practise of food sovereignty is manifested in the field and evaluate its potentiality, through a case study.

\subsection{Thesis Outline}

This thesis will be structured as follows:

Chapter 2 presents the research framework and the chosen methodological approach. This leads to an explanation of how my epistemology was constructed, as well as an outline of the methods chosen as a means to address the research objectives. A reflection about my positionality before and after the research will be offered, as well as ethical considerations regarding the research. Chapter 3 explores the concept of food sovereignty and goes through its evolution and expression around the world. The connections between the concepts of food sovereignty and agroecology will be exposed and elucidated. Chapter 4 seeks to establish the particularities and specificities of the rural areas in Ecuador. The role and nature of the agricultural sector will be presented. The final section of the chapter introduces the reader to 
the evolution of the peasant struggle in Ecuador, within the conditions of poverty and lack of access to resources. Acknowledging the visible changes in the government structure, and the attention that the rural sector has been given in the official discourse, Chapter 5 examines the current governance framework, and how food sovereignty is addressed by the current government through its structure, public policies and programmes. Chapter 6 is the first of two case studies, which exposes how social movements' agency has institutionalised its resistance to denial and dispossession. It presents what food sovereignty means for the National Federation of Peasant, Indigenous and Black Organisations (FENOCIN) and what specific actions have been put into place, in order to pursue food sovereignty. Chapter 7 is the second case study. It looks at the successful story of Kallari, a community-owned enterprise, which combines the principles of food sovereignty and agroecology, while improving the livelihoods of its members. Chapter 8 addresses each of the research objectives, scrutinises the evidence presented with the aim of assessing the significance of food sovereignty for farmers and analyses the effects of its implementation. It then presents policy recommendations for the achievement of food sovereignty, in the particular conditions of Ecuador. The final section of this chapter identifies further areas of research and offers final remarks. 


\section{Chapter 2}

\section{Research Design and Positionality}

This chapter will present the underlying epistemology and theoretical grounding that shaped the research design, data analysis and the writing up of this dissertation. I will briefly present the methodology utilised, and address in detail the methods I undertook for gathering and processing the data. Through my philosophical stance, I will explore and reflect on my own positionality and agency as a researcher, and will unveil the transformation I underwent in the process. I will conclude the chapter by exposing the ethical and cultural considerations that I imbued in this research.

\subsection{Philosophical Stance and Theoretical Grounding}

This dissertation is grounded on a social constructivist worldview. I chose this approach, because social constructivism seeks to understand the complexities of how people see the world and how a specific concept is lived and experienced by communities (Creswell, 2009). According to the research objectives exposed in chapter one, particularly questions one, three and four, the objective of this study was to understand how the concept of food sovereignty has evolved, how food sovereignty and agroecology is manifested in the field, and analyse how social agency related to food sovereignty has been exercised. In order to be able to elaborate on these research objectives, I decided to adopt an approach that was strongly grounded in the participants' perspectives. Hence the need for a longer period of time in the field. In order to complement the qualitative primary data, I have endeavoured to contextualise and frame the socio-cultural characteristics of the communities and stakeholders involved in my thesis, and take that into account in the data analysis. The latter responds to a personal consideration of the people involved, but also to academic carefulness linked to the application of the social constructivist worldview, in which the "historical and cultural settings of the participants" are an essential part of the analysis and data process (Ibid, p. 8). In addition, I have thoroughly addressed my positionality as a researcher, because it significantly impacts on the data collection and writing-up phases, and therefore is a very important element of the social constructivist approach. 
Furthermore, the reliability and validity of the knowledge generated are socially constructed by the research participants, instead of defined by prevalent structures. The latter proved to be especially important because the topic of food sovereignty has not been widely explored from a grassroots perspective, through a multiple case study approach and giving as much voice to the people. Regarding the value-laden aspect inherent in qualitative methodologies, which is occasionally criticised by post-positivists, I built upon feminist theories, particularly the writings of Sandra Harding in order to answer those critics and strengthen my philosophical stance. Feminist approaches claim that what has been considered as "value-free research" is indeed affected by the mainstream scientific community's values, considering only the perspectives of "qualified researchers and critics" (Harding, 1993, p. 70, emphasis added). Harding further notes that social values have a positive effect on the results of research and asserts that because the mainstream conception of science has marginalised communities, it is necessary to hear their voice through "democracy-advancing projects for scientific and epistemological reasons as well as moral and political ones" (Harding, 1993, p. 69).

Studying food sovereignty with a bottom-up approach is emancipatory in itself, due to its political implications. Emancipatory research has a critical component that challenges current structures and re-invents them, so as to allow for the formation of more equal frameworks. It encourages and pursues positive change. Along the same lines, Heron and Reason (2001) state that research should not be based on the researcher's outlook, but on the outlook of the people affected by the issue. This is a consequence, they claim, of treating participants as "passive subjects rather than as active agents" (Ibid, p. 179). They encourage research done with rather than on people, and insist on the importance of moving beyond the theoretical realm and including a practical component. Cooperative Inquiry incorporates a transformational approach, which places the participants as co-researchers, and has the potential to lead to empowerment and action (Heron \& Reason, 2001). These theoretical perspectives impacted on my epistemological stance for the design of this dissertation research. 


\subsection{Methodology}

My research is not based on a common mixed methods approach. I will not deny the importance of using quantitative data, mainly related to the analysis of statistical secondary information, but for me, the strength of my research will be grounded on a qualitative methodology, [with the complement of] case studies (Research Journal, 7 May 2012).

Research does not only address a given problem, but it is liaised with "personal experiences of the researcher, and the audience(s) for whom the report will be written" (Creswell, 2003, p. 21). Accordingly, my experiences and my epistemology had a clear impact on the methodology adopted. As mentioned previously, I was inspired by the social constructivist approach with emancipatory and cooperative attributes. The latter has a qualitative essence, and so, adopting a strong qualitative methodology allowed me to dig deeper into the understandings and the practice of food sovereignty in the field. It would not have been possible to gather such a dimension of information through a purely quantitative, or a conventional mixed methods approach. My main objective was to understand what made farmers' lives meaningful and if there was a connection with food sovereignty and agroecology. In regards to this, Brockington and Sullivan emphasise the "powerful techniques" of a qualitative methodology to unveil "what makes our world meaningful for people" (2003, p. 72). Nevertheless, the failure to appreciate the benefits of quantitative methodologies would have meant a limitation, particularly for unveiling the context of the rural sector, and of the conditions in which family farming develop in Ecuador. Along these lines, Murray and Overton (2003) underline the complementarity of quantitative and qualitative methodologies.

Because it is not possible to dissociate our work from our interests and feelings, I decided that it was far more prudent to focus the effort for doing this study with the more vulnerable groups, by including diverse actors and perspectives, and by emphasising their voices (Heron \& Reason, 2001). Emancipatory research is value laden, and therefore challenges the objectivity and neutrality of rigorous academic research, appealing to the moral and political attributes of the researcher (Harding, 1993; Scheyvens, et al., 2003). Acknowledging this aspect helped me realise the underlying philosophy that guided my research: a research that leads to action through the generation of knowledge from the communities' perspectives. 
Additionally, raising awareness has the power of changing people's attitudes towards socioenvironmental issues, which can then lead to action and active resistance.

\subsubsection{Case Study Approach}

For me, the role of the case studies is to give voice to the people (Research Journal, 16 July 2012).

Throughout this work, I have given special attention to my interviewees' voices, and to their reflections and positionalities. Firstly, because food sovereignty has not been widely explored from a community's point of view through a case-study approach; secondly; because a case study approach gives prevalence to the communities' perspectives over academic evidence, already explored in the literature review; and thirdly, because case studies have the potentiality of unveiling dimensions not planned or foreseen at the initial stages by the researcher. Indeed, the analytical and reflective process, that followed the data collection, composed the case studies' structure and bestowed them with unique characteristics, according to its nature. Having chosen a case study approach, it was appropriate to construct knowledge form the civil society's perspective, while gaining knowledge of the particularities of the case study chosen, and at the same time, revealing the dynamics that can be further extended and applied to other contexts and realities (Stake, 2003).

\section{Community Undertaking - Kallari Cooperative}

The design of case studies normally respond either to an attempt to dig deeper into the particularities of a community or a given situation, or to an attempt to generalise the study's findings. For this study I have attempted to understand and learn how the practice of food sovereignty is expressed in the field and what the practical implications of its practice offer to farmer communities. In order to do this, I tried to discover the milestones of the Kallari Cooperative's journey, the exogenous or endogenous nature of their success, and the lessons learnt that emerged from their experience. I resorted to academic journal and newspaper articles to have an external viewpoint, as well as online research of similar community undertakings, so as to offer a comparative analysis. I also endeavoured to put their particular characteristics into a global perspective, by identifying common features, in spite of the 
different socio-cultural conditions and geographies, in which the other community initiatives develop.

\section{Social Movements and the Institutionalisation of Food Sovereignty - FENOCIN ${ }^{3}$}

Complementary to the case study on the community, it was deemed necessary to conduct a case study on a social movement that had pursued the principles of food sovereignty and agroecology as part of their main focus, and that had grassroots origins. Through the exploration of this case study I sought to identify the importance of food sovereignty and agroecology for the movement, as well as the traits of social agency at the local, regional and national levels. The latter led the understanding of how food sovereignty was institutionalised in a nationwide and ethnically-diverse social movement.

\subsection{Research Methods}

The research methods were based on a mixture of primary, secondary, quantitative and qualitative data. However, as explained above, the qualitative methods prevailed.

\subsubsection{Primary Data}

The methods used for gathering primary data were: in-depth interviews, focus groups and field observations. During my time in the field, I had the opportunity to visit eight provinces. Figure 2.1 shows the political map of Ecuador. The provinces where field visits and interviews took place are highlighted with dots; and the provinces where case studies were conducted, are highlighted with triangles. Plain triangles represent the two sites for the case study of FENOCIN, and the triangle with the circle around, represents the case study of Kallari. Additionally, Table 2.1 presents a list of the provinces visited, according to the regions, and Table 2.2 presents a summary of all the research participants interviewed ${ }^{4}$.

\footnotetext{
${ }^{3}$ FENOCIN stands for National Federation of Peasant, Indigenous and Black Organisations.

${ }^{4}$ Appendix 2 presents the questions outline for the interviews, in English and Spanish.
} 
Table 2.1 - Regions and Provinces Visited During Field Research

\begin{tabular}{|l|l|}
\hline \multicolumn{1}{|c|}{ Region } & \multicolumn{1}{c|}{ Provinces Visited } \\
\hline Coastal Region & Guayas \\
\hline Sierra Region & Pichincha, Cotopaxi, Azuay and Loja \\
\hline Amazonian Region & Napo, Morona Santiago and Zamora Chinchipe \\
\hline
\end{tabular}

Elaboration: Author

Note: Table 2.1 lists the regions visited in direction from west to east and the provinces visited within each region in direction from north to south.

Figure 2.1: Political Map of Ecuador Showing Provinces Visited During Field Research

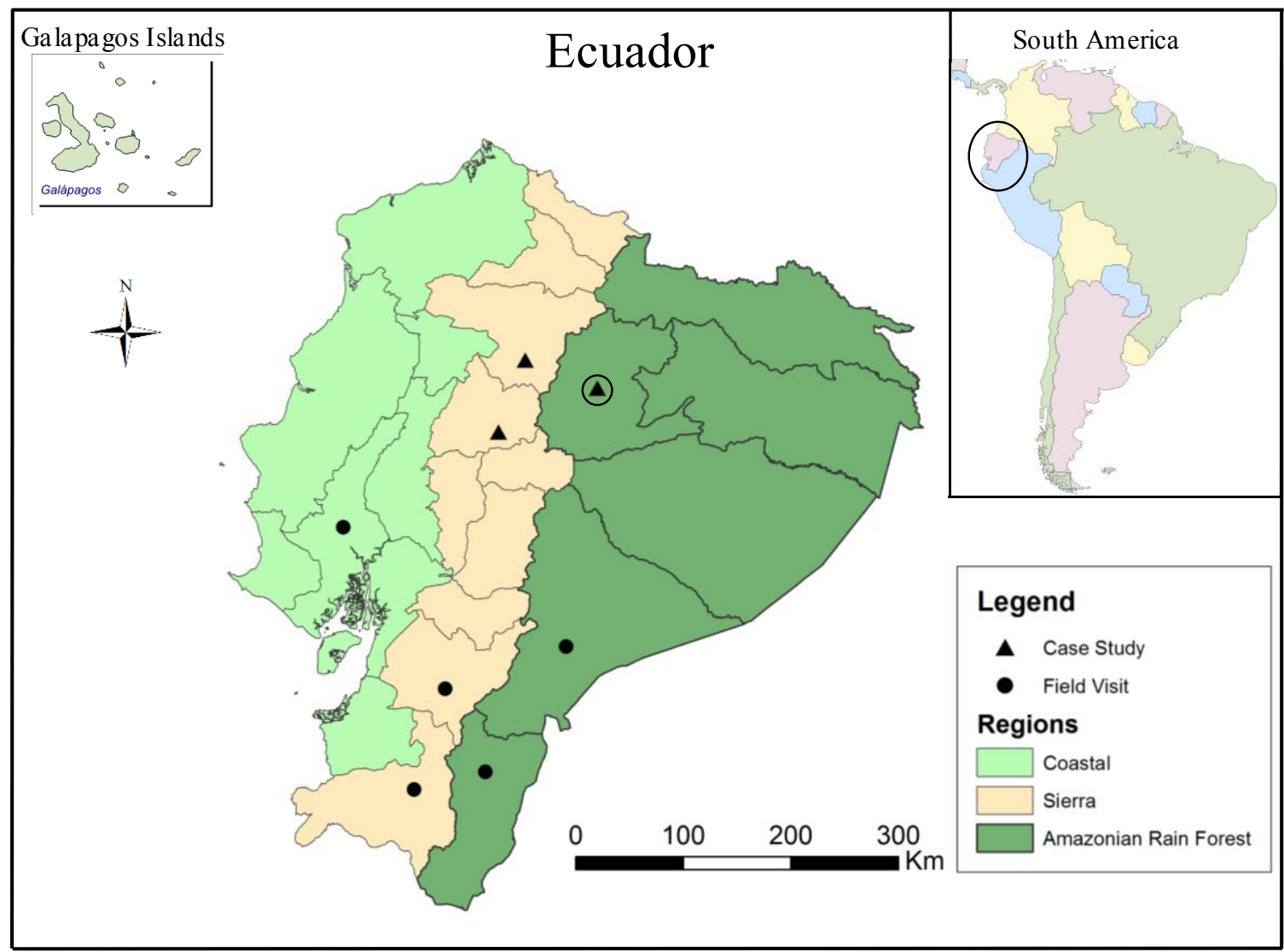

Elaboration: Andrew Rae and Author

Sources: D-maps (n.d.-a); D-maps (n.d.-b); and, Souris (n.d.) 
Table 2.2: Research Participants

\begin{tabular}{|l|c|c|}
\hline \multicolumn{1}{|c|}{ Description of Research Participants } & Code & $\begin{array}{c}\text { \# of } \\
\text { People }\end{array}$ \\
\hline \multicolumn{1}{|c|}{ INTERVIEWS } & MA & 6 \\
\hline Technical staff of the Ministry of Agriculture & PG & 3 \\
\hline Technical staff / political leaders of three provincial governments & MP & 3 \\
\hline Technical staff of one municipal government & AC & 1 \\
\hline Academic specialised in political economy, rural development and social movements. & NGO & 18 \\
\hline $\begin{array}{l}\text { Technical staff of NGOs working at grassroots level on topics such as sustainable rural } \\
\text { development and food sovereignty }\end{array}$ & OBS & 5 \\
\hline $\begin{array}{l}\text { Focus group with the Observatory of Socio-Environmental Conflicts - Universidad } \\
\text { Particular de Loja }\end{array}$ & FCF & 7 \\
\hline Focus group with Members of a Farmers' Community in the Province of Loja & CFS & 2 \\
\hline Plurinational and Intercultural Conference on Food Sovereignty (COPISA) & FA & 31 \\
\hline $\begin{array}{l}\text { Farmers and leaders of community associations and/or coordination platforms around } \\
\text { Ecuador }\end{array}$ & Subtotal & $\mathbf{7 6}$ \\
\hline & FASE STUDIES & KAL \\
\hline National Federation of Peasant, Indigenous and Black Organisations - FENOCIN & 6 \\
\hline Kallari Cooperative & Subtotal & $\mathbf{1 0}$ \\
\hline & $\mathbf{8 6}$ \\
\hline
\end{tabular}

Elaboration: Author

\section{In-depth Interviews}

In-depth interviews were the main source of information and data collection. I tried to let the interviewees talk freely about the aspects that were important for them, in relation to food sovereignty. As suggested by Creswell (2003) and Yin (2011), the process of collecting data and understanding the participant's point of view results in rich and exhaustive conversations. There were also several informal conversations with thought-provoking material that emerged from my field visits. Not all of them were recorded, but in most of the cases, notes were taken. As underlined by Brockington and Sullivan (2003), every conversation unveiled interesting aspects that merited attention and further analysis from an academic point of view. But more importantly, those conversations constituted a beautiful and invaluable learning experience at a personal level. 
During the research design phase and while in the field, I followed Yin's suggestions about interviewing skills, and always tried to create a space where people could express freely. For this to be achieved, I avoided influencing the responses (Yin, 2011). Accordingly, interviews resembled a conversation, rather than an interview, and hence questions were not "strictly scripted", but served as a mere guide to the dialogue maintained, and were adapted according to the context and setting of the interview (Ibid, p. 134).

\section{Focus Groups}

I designed guide questions and explored the literature about how to effectively conduct focus groups (Creswell, 2009; Yin, 2011). However, the dynamics in the field did not allow for the conduction of many focus groups. For instance, I could only conduct two focus groups, which impacted on the dissertation and enriched the analysis, particularly for cross-checking. Notwithstanding, the focus groups were not thoroughly analysed or transcribed. I learnt that, while it was important to be prepared with the knowledge of methods and the related ethical considerations, researchers need to be flexible and resourceful in order to adapt to the opportunities that emerge in the field.

\section{Field Observations}

Field observations were one of the main methods utilised for conducting the case studies and were also relevant for the analysis and assessment of the governance tool implemented by the Ecuadorian Government in relation to peasant farming in the rural areas of Ecuador: the Agrarian Revolution Schools (ERAs). The objective was to observe the content and scheme of the training programme, so as to identify to what extent the schools are led by the communities, whose interests are represented by the course structure, and if experimental learning and traditional knowledge were taken into account. 


\section{Stakeholder Analysis}

A comprehensive stakeholder analysis was undertaken, in order to identify the key actors who were contacted in the initial phase of the field research. The information for the construction of the stakeholders' matrix was drawn mainly from the secondary data analysis of diverse material, such as newspapers, academic literature, official media releases from governmental institutions, publications by NGOs and social movements, as well as information available in the websites of national and sub-national authorities. Through this analysis, I could identify three stakeholder groups: a) Group One: composed of national and local government officials; b) Group Two: composed of staff from grassroots NGOs or national/international NGOs that have a focus on agroecology, family farming, traditional ecological knowledge or rural sustainable development. This group allowed me to have access (gatekeepers) to communities for in-depth interviews and field visits; c) Group Three: composed of community leaders, leaders of farmers' organisations, indigenous and political leaders.

\section{Ethical Considerations}

The first step to avoid transgressing any ethical barrier was to gain Ethical Approval from Victoria University Review Board. In observance with Victoria University's Human Ethics Policy every participant was given an information sheet about the research and an informed consent form, that they signed, indicating if they wanted to be recorded, and how the wanted to be identified. ${ }^{5}$ Nevertheless, while in the field, it proved socially inappropriate to ask for a written document, particularly in contexts where agreements are made verbally. Insisting on having the forms signed, might have raised suspicions about the intention of the research, or damaged the rapport with the researcher.

Farmers and community leaders were willing to have an informal conversation about the topic with only verbal consent. I digitally recorded the interviewees consent, given that the interviewee accepted to be digitally recorded, or else I wrote down on my research journal how the participant wanted to be identified in the study. If so, they will be referred to as $R P$ Code-Number. RP stands for research participant; the code refers to the type of research participant, according to Table 2.2; and, the number given is a randomly allocated

\footnotetext{
${ }^{5}$ See Appendix 1 for the complete documentation related to the Victoria University's Human Ethics Approval.
} 
identification number to differentiate between participants. In order to guard my participants' safety, all of them will remain anonymous, except those who have requested to be identified. The ethical considerations that shaped my study include the need to give as much voice as possible to my research participants. I endeavoured to stay as truthful as possible to my research participants' views, while at the same time remaining truthful to myself as a researcher. Therefore after the submission of this dissertation, I will elaborate a document in Spanish with the most important aspects of the thesis, which I will hand over to all my research participants. I will also hand over a full translation of the case studies to the institutions and communities involved.

\subsubsection{Secondary Data}

I analysed secondary data, in the form of laws, policies, official and academic publications, news and political statements. The objective was to understand and assess the governance structure and identify mechanisms in which rural sustainable development can be promoted. Quantitative secondary data was utilised for understanding and presenting the context in the rural areas, as well as the agrarian change and challenges in Ecuador. For the case studies, it proved of paramount importance to resort to a mixture of primary and secondary data: indepth interviews and field observations were the main methods related to primary data, while secondary data complemented the information gained, delved into the knowledge of the case, and also offered a third party viewpoint. This approach enriched the knowledge generated through the case study and balanced the objective and subjective aspects of research. It further strengthened evidence, through the use of multiple sources (Robson, 2002).

\subsection{Difficulties and Lessons Learnt}

Before getting into the field I was not fully aware of the agency at the community level and the degree of implementation of food sovereignty and agroecology that I was going to find. I found several successful stories of community undertakings that brought them closer to the achievement of food sovereignty. I was delighted to find a community-owned vertically integrated undertaking that resembled the principles of food sovereignty and contributed to a remarkable improvement in the community's livelihoods. In my original plan, I was going to conduct a case study on a grassroots NGO, and how they apply the concepts of food 
sovereignty and agroecology in the field. But instead, I chose to conduct a case study on the community-owned project. This experience showed me that taking advantage of the opportunities presented in the field and consequently adapting the research design and the data analysis was far more prudent than adhering to the original plan.

My impetus and enthusiasm towards the learning experience that the field research would offer, as well as the possibility of experiencing my own country in a different way, led me to conduct a large amount of interviews. I did not waste any opportunity to talk to people or do a field visit. While this aspect made my learning experience rich, it also complicated the data analysis and required a longer time to classify and work through the information gathered. This taught me that it is more sensible to stop and examine how important the new visit or interview might be for my research and to what extent it will add value to the study. A good balance between the surprise element and adhering to the original plan would be excellent. Nevertheless, I refuse to see field research as a purely academic exercise, and accordingly, the personal experience with the extended field research balanced the impracticalities generated by the copious information gathered.

Finally, travelling on my own around the rural areas of my country was a matter of concern for my family and me. A young woman in the Ecuadorian context (and I would assume, in the Latin American context) is seen as easy prey for robbery or any type of assault with sexual and physical assault unfortunately a real threat. I was aware of those risks, and therefore took some precautionary measures: a) some provinces in the coastal region, as well as the provinces in the Sierra and Amazonian rainforest that are located in the border of Colombia, are known for being more dangerous than other zones. I deliberately chose not to conduct my research in those areas, and strongly focused on finding research participants and community undertakings in relatively safer regions of the country; b) I would go to a field visit with NGO staff, not on my own, and avoided doing field visits with only male staff. Most of the time I preferred to liaise with female staff, or with a mixture of both; and, c) before going to meet my interviewees in their offices, particularly if they were males, I would double check the address they gave me with the address of the NGO or institution that was found on the internet or in the phonebook. 


\subsection{Analysis of Data}

In alignment with the universal approach to analysing data, proposed by Kitchin and Tate (2000), I utilised a multiple stages approach that allowed me to categorise and identify connections within my research information. I resorted to recordings, field notes and my research journal, in an iterative way, which allowed for the description, classification and interconnection of data. The associations and interconnections found in the data from primary and secondary sources were matched and categorised, so as to identify links and common threads that contributed to the generation of knowledge around the themes explored. Due to the fact that qualitative data analysis is highly interpretative, I was careful not to deviate my interpretations from the evidence, and therefore utilised a two-fold approach: firstly, the thorough field research allowed me to cross-check the evidence found in my analysis. Accordingly, I did not draw conclusions without validating my findings with empirical evidence; and, secondly, I also corroborated, compared and scrutinised the information found in the academic literature with my findings.

\subsection{Reflections on my Positionality}

[T]he experience of research does not end with one's exit from the field: it overflows as the sensations produced by memories of place, people and events conjured up in the process of constructing a written story from the field notes and data brought home"(Brockington \& Sullivan, 2003, p. 68).

The overflow described in the above quote is the aspect that most enriched my experience as a researcher, and therefore the one that most impacted on my positionality. In the following paragraphs I will expose my positionality and how it has been transformed by the overflowing and reiterative memories from the field. For this purpose, I will firstly expose my positionality before going into the field; subsequently I will present some of my research participants' positionality, which were the main driving force for the shift in my perspective and the consolidation of a more holistic ideology; and finally, I will describe my positionality after the field research and writing up processes. This section is based on a paper entitled Sovereign 
Chicha: Reflections on Research Positionality that I presented at the New Zealand Geographical Society Conference, in December 2012 (Cevallos Cazar, 2012a). ${ }^{6}$

\subsubsection{My Original Positionality}

Despite my ignorance of the rural and peasant realities, my motivations and the rationale for conducting a study on food sovereignty were informed by the vast evidence of the environmental, social and cultural damage caused by conventional agriculture. While I had attempted to explore my positionality before going into the field, that exploration became stronger and more apparent throughout the research process and the interaction with my research participants. In connection to this, Creswell (2003) recognises the simultaneous duality and unity of the researcher and the personal-self. While there has been debate in the literature about the effect of the researcher's values on the research process, there has been less on how the study affects the researcher. In my experience, the latter was stronger and more powerful than the former, particularly in relation to my connection and understanding of nature. I am a mestiza, middle-class woman, who was born and raised in the capital city, in a very urban context, where services, benefits and power had been mostly centralised in the capital city, Quito. My relationship to Pachamama had not been consistently nurtured as in the case of people who live and breathe the mountains, lakes, sea or rainforest every day. This nurturing and enjoyment process was not a daily activity for me but was confined to my recreational time, occasionally during the weekends or on holidays. Additionally, being mestiza embeds a mixture of worldviews and perspectives, "because I am in all cultures at the same time" (Anzaldúa, 2007, p. 99). Therefore, my worldview and my ancestors' worldviews were diverse and varied, far from the consideration of non-human life forms in our everyday lives with the same intensity as in the case of rural communities.

\subsubsection{My Research Participants' Positionality}

My research participants' worldviews are imbued in the rich and diverse nature and ecosystem characteristics that surround them. Their leisure and well-being are connected to nature, their food supply comes from nature and their livelihoods, and the provision for all

\footnotetext{
${ }^{6}$ Information about the presentation and abstract of the paper can be accessed through e-mail request to paocevallos@gmail.com.
} 
other needs. Most of the communities I visited were located in areas far away from cities. Through our conversations, it became clear to me that for my research participants, particularly for farmers, community leaders and field technical staff, the socio-cultural dimension of food is always connected to food production, and this persistently connects them to the environment. The reflections of one of the research participants on the use of agrotoxics in food production depict his positionality towards Pachamama:

I used to say to [my fellow farmers] that they get the soil drunk with many chemicals. 'When you are drunk, what do you do? You say things that you wouldn't say if sober. You bring up all what you have inside. You even get brave! That is what we do to the soil when we use agro-toxics. But the next day you are hungover, feel terrible and do not know what to do. Well, that is exactly what happens to the soil (RP-FEN-1, 2012, author's translation)

Moreover, my interviewees' deep relationship with nature was expressed through personifications and even through a fellowship with the surrounding animals and plants:

I don't mind if the birds eat [my] fruits, because early in the morning, at 6.00 am or before 6.00 am birds sing. And there is one bird, [called] chirote, which makes noises: tac, tac, tac in the window. So I tell my children: 'See how it calls you?' It is so nice to see the birds! When they eat our crops, we cannot do anything. It is worse to be angry with them, because they make more damage. I rather talk to them and say: 'I saw that you already ate your part [of the crops]!' They poke their beaks into the large strawberries! I rather talk to them and say: 'you may eat', and this way they do not eat as much (RP-FA-1, 2012, author's translation)

As it can be inferred in the above quote, they express their relationship to Pachamama through personifications of the soil and the surrounding flora and fauna. The animals they breed are treated with much affection, similar to that offered to house pets. Additionally, it is important to note how they share part of their production with birds, which "come and try" their crops. In fact, farmers appreciate the variety and diversity of the fauna that their chacras have, ${ }^{7}$ as this proves that their production is good and natural, not to mention the increased pollination through the action of birds and insects. Birds try those crops because they have been produced naturally. In the cases of crops produced with chemicals, birds and insects are present in significantly smaller amounts (Losey \& Vaughan, 2006).

\footnotetext{
${ }^{7}$ Chacra is the Kichwa word for swidden-based orchard.
} 
Finally, the way of sharing food amongst farmer or indigenous communities also represented a different perspective of communal cohesion and interaction. For example, chicha, a traditional Andean beverage, is served in the same bowl for everyone. This way of sharing, places every guest at the same level and provides momentum for discussion, deliberation and comradeship, simulating the harmony between their chacras and the Pachamama. As a consequence, I started to realise that I wanted the same harmony to be evident in my thesis, a harmony between their story and this dissertation.

\subsubsection{My Enriched Positionality After Research}

[W] hat we like, what we eat, how we eat it and how we feel about it are phenomenologically interrelated matters; together they speak eloquently to the question of how we perceive ourselves in relation to others (Mintz in G. V. García, 2007, p. 38).

My experiences in the field, the time I shared with my interviewees and the community gatherings I participated in, confirmed what I had long believed; that food is much more than a physiological need. Indeed, it is a powerful expression of culture, through which we can learn more about customs, traditions, the produce of a place and even its environment and geography. It also creates a space for social interaction and debate. And yet, particularly in developing countries, food has been commodified and hoarded, so that communities have restricted access to healthy and culturally-appropriate food; they are not able to grow and enjoy their own food; complicating the preservation of their customs and traditions, and the associated knowledge.

After my time in the field, I became more aware of my own positionality and politics, as well as more conscious about the responsibilities towards my research participants. The possibility of having an 'agenda' raised the concern of the potential to privilege positions and views that could favour the concepts that this thesis seeks to assess. While sufficient evidence about the principles of food sovereignty and its benefits were easily found in the literature, I was apprehensive about the likelihood of romanticising the concept. And so, I was confronted with my positionality regarding the ethics of 'taking sides' for the communities, and how this could influence my understanding and interpretative capacity for this study. Feminist epistemologies cross-examine the ties and connections between the production of knowledge and ethics (Harding, 1993, p. 72). Considering this, it would have been unethical for me not to 
challenge the structures associated with mainstream agriculture and agro-industry, which I believed were perpetuating inequality. Hence, my empathy towards farming communities was no longer a threat to the validity of my research, as long as I would endeavour to give voice to actors with conflicting interests, and as long as I remained faithful to my own positionality and critical standpoint.

I further discovered that although our gender, ethnicity and class have an impact on our positionality, they do not define it, as our ideology does. And how that ideology makes us feel and think, determines our positionality, the way in which we learn, understand and interact with our world, and finally how we exercise our agency. It follows then, that the more I would open myself to this experience of visiting their world and being open to their worldview, the more my worldview was affected and enriched (Takacs, 2003). As a consequence I underwent changes in the way in which I relate to Pachamama, food and food production, and these changes were knitted through the interactions with the research allies. I wandered from loving food, to loving how it was produced and what was implied in its production. Likewise, my conception of 'development' was further challenged and accordingly shifted to a more holistic one, which would necessarily include a thorough participation of the community involved.

\subsection{Reflections on my Agency as a Critical Researcher}

Throughout the writing process of this dissertation, I went through different expressions of agency. In the research design process I felt passionate and energised, ready to discover and be surprised, and eager to learn. When I started writing, I was overwhelmed with the abundance of information gathered and unsure about where the processing and analysis of data was going to lead me. I started focusing more on finishing on time and complying with the formalities of time and structure, than on agency and action. On occasion I found myself loosing awareness of the bigger picture and leaving behind my passion for rural sustainable development. However, the reiterative process of going through my field notes and recordings brought me back on track and helped me focus on the important thing: giving voice to the people and genuinely representing their views, while imbuing sufficient academic scholarship in my work. This reminded me of my initial motivations and the agency component of this dissertation, beyond the academic achievement: I wanted to write a thesis that could 
contribute to practice and was based on the empirical experience of the field experts: the peasants who day after day work the soil, domesticate seeds and help keep alive traditional food and the associated customs and culture.

Looking back at the logistics of field research and periods of writing, I briefly thought that making my field research simpler and focused on the specific information needed for completing the degree would have been preferable. Having a reduced field research period would have saved much time, money and effort. Nevertheless I have also learnt that research designs are never accurate and that researchers need to be effectively prepared for the unexpected. Accordingly, flexibility and adaptability are crucial for a successful field experience. From a practical and ethical perspective, I would not have given up one single interview, field visit or community gathering. The experience I had in my field research was a great learning opportunity and had a great influence on my preparation as a development professional. What I understand under the term research with a purpose is a circular relation between practice and theory, in which both are interdependent and have the mission to contribute to each other. The main component of this mutual and bidirectional relationship is the practical realm, for it is there where theory proves to be valid and relevant.

\subsection{Summary}

This chapter has presented the epistemology and philosophical stance that shaped my study. Social Constructivism harmonised with my research objectives and allowed for the exploration of the community's worldviews and perspectives. Feminist theories and applications of emancipatory research influenced on my methodological approach. The research methodology was mainly qualitative, but was complemented with quantitative data analysis and a case study approach. Most of my research was done through in-depth interviews and field observations. My positionality was transformed as a result of the interaction with my research participants and the knowledge generated with the research process, particularly in relation to how I relate to nature, food and food production. My agency as a researcher has persistently been at the back of my mind, allowing me to be more critical towards academic research that does not lead to action, or that is not generated from a grassroots perspective. With the presentation of my philosophical stance, methodological 
approach and positionality, I have attempted to expose the foundations of the thesis and thus lay the ground for the upcoming chapters. Chapter 3 will present a thorough literature review on food sovereignty and agroecology, in an attempt to unveil its holistic nature. 


\section{Chapter 3}

\section{Food Sovereignty as a Concept - the Convergence of Theory and Practice}

This chapter will present a literature review on the concepts of food sovereignty and agroecology, and explain their interrelation. Special attention will be given to the concept of extractivist agriculture and its implications for farmers and consumers to provide a deeper foundation for understanding food sovereignty and its holistic meaning. This chapter will also present evidence about the political component of food sovereignty, and expose how it is practiced, first at a global level, and then focussing on Latin America and the Caribbean. The aim of this chapter is to afford the reader a clear understanding of the wider meaning of food sovereignty by presenting the current debates and discussions around this topic. In doing so, this chapter will address the first research objective.

\subsection{Food Sovereignty - Origin and Evolution}

The term food sovereignty has been defined and conceptualised in many different and sometimes inaccurate ways (Patel, 2009). These various definitions have created confusion, and as a result, the term food sovereignty has been associated with food security. Food security is concerned with satisfying the "steady expansion of food consumption, [...] through the availability of adequate food supplies [...] ensuring [...] physical and economic access [...] of all people at all times to enough food for an active, healthy life" (FAO, 2003, p. 27). ${ }^{8}$ In contrast, food sovereignty implies a culturally-appropriate and sustainable local production aimed at benefiting communities rather than markets and corporations (La Via Campesina, 2011). Although the term food security has evolved to a wider definition that incorporates concepts like nutritious food, food preferences and a healthy life (FAO, 2003, p. 28), the concept is still far from the holistic approach of food sovereignty. Moreover, it could be argued that the attempts to stop a global food crisis, especially during the 1960s and 1970s, led to the current worldwide lack of land and food sovereignty (Patel, 2009). It follows that food security and food sovereignty represent opposite ideologies, as food sovereignty has

\footnotetext{
${ }^{8}$ This definition has been taken from the official definitions of Food Security by FAO, in 1974, 1983 and 1986.
} 
wider implications for communities. The definition used by La Via Campesina movement in 2002 is even more precise about the conceptualisation of food sovereignty:

Food Sovereignty is the RIGHT of peoples, communities, and countries to define their own agricultural, labour, fishing, food and land policies which are ecologically, socially, economically and culturally appropriate to their unique circumstances. It includes the true right to food and to produce food, which means that all people have the right to safe, nutritious and culturally appropriate food and to food-producing resources and the ability to sustain themselves and their societies (Quoted in Blouin, et al., 2009, p. 2, original emphasis).

In order to gain a deeper understanding of how food sovereignty relates to the lives of millions of farmers and urban or rural consumers around the world, the next section will look at the implications of the conventional extractivist approach to agriculture.

\subsection{Extractivist Agriculture - Implications for Communities and the Environment}

For this particular study, extractivist agriculture refers to the intensive use of natural resources, seeking to produce beyond the natural limits of the soil and the ecosystem. Hence, extractivist agriculture resorts to strong agro-chemicals to artificially boost the soil nutrients and ecosystem services that have been eroded by intensive practices. The latter also destroys the natural protection against pests and other crop diseases, which is in turn compensated for by the use of more chemicals. Extractivist agriculture is based on the support of monocrop plantations, as opposed to multi-cropping and diversification. Additionally, it has strong links with the agro-industry and agro-export sectors and responds to the neo-liberal perspective of food and food production. Extractivist agriculture seeks to satisfy markets instead of people's demands, and thus commodifies food and jeopardises the socio-cultural and environmental aspects related to food production.

Extractivist agriculture, as we know it today, expanded in the mid-1960s, when the acceleration of crop productivity was seen as the solution for the ever-growing population and the fear of a global food crisis, particularly in Asia (IFPRI, 2002). This phenomenon was coined under the term Green Revolution, around 1968, and involved the use of high-yielding varieties (HYVs) of crops and hybrid seeds, as well as potent fertilisers and pesticides (Ibid). 
Subsequently, the intensive use of machinery was also part of this agricultural approach (Meehan, 2010). This practice started in India and expanded worldwide, especially in developing countries. Specialisation in the production of certain crops, such as rice, wheat, corn and soya, also took place. From 1960 to 1990, the total cultivated area for rice and wheat went from $30 \%$ to $70 \%$ (Ibid). Despite the economic gains seen in Asian countries with large extensions of land devoted to crops, the inequalities between urban and rural areas were accentuated. Moreover, the economic growth in small Latin American countries was limited and the inequalities between the peasant, bourgeoisie and elite classes increased (Kay, 1995).

In spite of the discussion around eliminating malnutrition through intensive agriculture, food prices have steadily increased, making access to appropriate levels of food more difficult for vulnerable communities. Holt-Giménez noted that "the World Bank reported [a rise in] global food prices of $83 \%$ over the last three years and the [Food and Agriculture Organisation of the United Nations - ]FAO cited a $45 \%$ increase in their world food price index in just nine months" (2009, p. 143). As the practice of extractivist agriculture has deep implications, and causes hindrances, to the achievement of food sovereignty, it is worthwhile looking at the core characteristics of extractivist agriculture. In Table 3.1 I will present a comparative analysis that summarises the implications of extractivist agriculture and the food sovereignty approach in relation to five aspects: a) climate change, b) intensive use of agro-toxics, c) widespread use of genetically modified (GM) crops, d) hindrances to the nutrition of farming communities, and e) economic, social and cultural implications. 


\section{Table 3.1: Comparison of Extractivist Agriculture and the Food Sovereignty Approach}

\begin{tabular}{|c|c|c|}
\hline $\begin{array}{l}\text { ASPECT OF } \\
\text { ANALYSIS }\end{array}$ & Extractivist Agriculture (EA) & Food Sovereignty (FS) \\
\hline $\begin{array}{l}\text { Climate } \\
\text { Change }\end{array}$ & $\begin{array}{l}\text { EA generates great amounts of green-house gasses (Casado \& Hernández, 2012). } \\
\text { EA does not offer farmers resilience to face the effects of climate change. } \\
\text { According to Nicholls and Altieri, "Resilience is defined as the tendency of a } \\
\text { system to maintain its organizational structure and productivity after } \\
\text { disturbance. This disturbance may be a frequent, cumulative or unpredictable } \\
\text { stress. [...] [R]esilience embodies two aspects: resistance to shock, and capacity } \\
\text { and speed of recovery after the shock" (2012, p. 33, author's translation). }\end{array}$ & $\begin{array}{l}\text { FS increases resilience to weather extreme events, through the use of local } \\
\text { seeds, which are tolerant to drought and flood (Altieri \& Toledo, 2011). } \\
\text { The use of agroforestry softens climatic fluctuations like frost and heatwaves } \\
\text { (Nicholls \& Altieri, 2012). } \\
\text { FS contributes to the sequestration of greenhouse gases, especially carbon } \\
\text { dioxide and nitrogen (Casado \& Hernández, 2012). }\end{array}$ \\
\hline $\begin{array}{l}\text { Intensive Use } \\
\text { of Agro-Toxics }\end{array}$ & $\begin{array}{l}\text { EA uses a great amount of chemical components that originate from fossil fuels, } \\
\text { which makes this practice energy inefficient (Casado \& Hernández, 2012). } \\
\text { The large use of chemicals breaches the ecosystem balance and generates a } \\
\text { vicious cycle, in which more and more synthetic compounds are needed } \\
\text { (Comunidad Andina, 2011). } \\
\text { The use of heavy chemicals pollutes the soil, springs and other water sources } \\
\text { (Altieri \& Toledo, 2011). } \\
\text { Intensive use of agro-toxics affects the farmers' health, as they take on all the } \\
\text { risks inherent to that activity. } \\
\text { Agro-toxics also contaminate the crop's fruit (Bustos \& Bustos, 2010), which } \\
\text { affects the end-consumer's health. }\end{array}$ & $\begin{array}{l}\text { FS resorts to organic material and agroecological techniques, which makes it } \\
\text { energy efficient (Casado \& Hernández, 2012). } \\
\text { Energy efficiency improves the soil quality and improves water management } \\
\text { (Ibid). }\end{array}$ \\
\hline $\begin{array}{l}\text { Genetically } \\
\text { Modified } \\
\text { (GM) Crops }\end{array}$ & $\begin{array}{l}\text { EA uses GM crops, which are resistant to pests and diseases, as well as to the } \\
\text { aggressive effects of pesticides (Larach, 2001). } \\
\text { There is no clarity about the effects of GM on humans' health and the } \\
\text { environment (Meehan, 2010). }\end{array}$ & $\begin{array}{l}\text { FS does not use any type of GM seed, but only local and traditional seeds. This } \\
\text { allows for: a) low-price, internally produced inputs; b) a greater diversity per } \\
\text { growth season; and, c) reduced harvest variability (Altieri \& Nicholls, 2000). }\end{array}$ \\
\hline
\end{tabular}




\section{Table 3.1: Comparison of Extractivist Agriculture and the Food Sovereignty Approach (continuation)}

\begin{tabular}{|c|c|c|}
\hline $\begin{array}{l}\text { ASPECT OF } \\
\text { ANALYSIS }\end{array}$ & Extractivist Agriculture (EA) & Food Sovereignty (FS) \\
\hline $\begin{array}{l}\text { Hindrances in } \\
\text { the Nutrition } \\
\text { of Farming } \\
\text { communities }\end{array}$ & $\begin{array}{l}\text { The extensive use of GM crops endangers the conservation of the biodiversity, } \\
\text { which sustains balance in nature and supports human nutrition (Comunidad } \\
\text { Andina, 2011). } \\
\text { The genetic variety of fruits and vegetables have been significantly diminished, } \\
\text { and most of the world's food supply comes from eight star crops (Meehan, 2010). }\end{array}$ & $\begin{array}{l}\text { Farmers traditionally cultivate a variety of crops, which allows them to: a) } \\
\text { provide their families with a holistic and culturally-appropriate nutrition; and, b) } \\
\text { maintain genetic variety through the domestication of seeds (Nicholls \& Altieri, } \\
\text { 2012). }\end{array}$ \\
\hline $\begin{array}{l}\text { Economic, } \\
\text { Social and } \\
\text { Cultural } \\
\text { Implications }\end{array}$ & $\begin{array}{l}\text { EA encourages the cultivation of cash-crops in the form of monocultures, } \\
\text { which: a) are sold for low prices that do not offer farmers a decent income and } \\
\text { leave all profits in the hands of the middleman and retailer (De Schutter, 2010, } \\
\text { 2011; Shiva, 2005a); and b) makes farmers dependent on fluctuating market } \\
\text { prices. } \\
\text { EA leads farmers into debt (for machinery and chemical inputs), but production } \\
\text { and credit payment cycles do not coincide, thus affecting the economy of small- } \\
\text { scale farmers (De Schutter, 2011). } \\
\text { Because farmers do not cultivate local seeds, they do not put into practice their } \\
\text { traditional knowledge. Losing traditional knowledge perpetuates the continual } \\
\text { loss of diversity and the emotional and cultural connections to nature (Bustos \& } \\
\text { Bustos, 2010; GIZ, 2011a). }\end{array}$ & $\begin{array}{l}\text { FS resorts to multi-cropping, as well as culturally and environmentally-friendly } \\
\text { techniques, which: a) assures the availability and access to food for the } \\
\text { following generations (Altieri, 2009); b) allows for the production of healthy and } \\
\text { affordable food for farming and non-farming communities (Bustos \& Bustos, } \\
\text { 2010); and c) allows farming communities to be able to address all their } \\
\text { families' nutritional requirements through their production, because they are not } \\
\text { producing cash crops. They first produce food for their families, and the excess } \\
\text { is sold to the non-farming population (Comunidad Andina, 2011). } \\
\text { FS allows for full-labour employment through the involvement of the whole } \\
\text { family (Casado \& Hernández, 2012). } \\
\text { The low-inputs dynamic, as well as the access to local markets, allows a } \\
\text { tangible increase in the return received by farmers (Holt-Giménez, 2009). }\end{array}$ \\
\hline
\end{tabular}


As can be seen in the above table, extractivist agriculture creates serious implications for farming and non-farming communities as well as the environment. In spite of this fact, academics, politicians and entrepreneurs who comply with and accept the neo-liberal and market-based approach, insist on the economic inefficiency of family farming. I argue that through food sovereignty, it is not only possible to have high yield levels, but also to generate an income that allows farmers to improve their livelihoods. At the same time, intergenerational equity can be exercised, through the consideration of the ability of future generations to have access to productive resources and fulfil all the needs of their families. This statement will be further analysed in Chapter 8, through an in-depth exploration of the economic component of food sovereignty, referencing the evidence presented throughout this study.

\subsection{Organic Farming - the First Step for Change}

In the mid-1920s, as a reaction to the harmful effects of extractivist agriculture and as a practical form of resistance to its methods and philosophy, the initiative of organic livestock farming was driven by the definition of general organic guidelines. Subsequently, the International Federation of Organic Agriculture Movements (IFOAM) further developed the concept's framework (Bonti-Ankomah \& Yiridoe, 2006). The principal concerns that motivated the expansion and widespread practice of organic farming were: a) disadvantageous conditions for farmers; b) lack of food safety; c) human health issues; d) absence of animal welfare considerations; and, e) environmental negative effects (Ibid).

Movements of peasants, indigenous communities, environmentalists and scientists motivated the expansion of organic agriculture, which had been substantially supported by consumers around the world, particularly from the 1960s onwards (Tamayo, 2009). However, while organic agriculture has greatly benefited from information campaigns and consequent consumer support, organic farming is a very broad concept that receives diverse interpretations. For example, the use of monocultures and some 'mild' chemicals are still accepted under the organic philosophy ( Altieri \& Toledo, 2011). Additionally, organic farming can become an expensive alternative, as the use of external inputs to control pests and to boost the soil fertility is still required. Furthermore, it requires a certain level of 
specialisation, which may deny farming communities the use of their existing knowledge and practices (Ibid). These considerations, together with the increased concern about the expansion of biofuel monocrops, and the realisation that organic farming is focused exclusively on biological and biodynamic interactions and not on social and cultural aspects (Wezel et al., 2009), encouraged the furthering of studies related to ecologically-based ways of production, resulting in the development of the agroecological sciences (Altieri, 2009).

\subsection{Food Sovereignty and Agroecology}

The resurgence of traditional epistemologies and the emergence of environment and community-focused post-development approaches (Pieterse, 1998), allowed for the consideration of values that surpassed the economic focus. Additionally, the indigenous worldview, associated with a "profound spirituality that upholds [the human] relationship with Mother Nature" (Cunningham, 2010, p. 91), and thus pursues a holistic well-being (Tauli-Corpuz, 2010), ${ }^{9}$ has been increasingly explored and adapted to classic rural development conceptions. The appreciation of traditional knowledge and alternative concepts has increased over time, as has the awareness of the importance of locally-based development models (Altieri, 2009; Bustos \& Bustos, 2010). Also, disbelief in organic agriculture, the increasing interest in and respect for traditional lines of thought, and the widespread practice of participatory and community-based activities, facilitated the emergence of agroecology.

While its origins date back to the late 1920s, agroecology gained importance in the academic and practical fields during the 1970s and 1980s, and was consolidated in the 1990s (Toledo, 2012; Wezel \& Soldat, 2009). The pioneer in coining the concept was the Russian agronomist B. M. Bensin in 1928 (Toledo, 2012). The agroecological approach combines scientific knowledge and the application of new technologies in conjunction with indigenous and traditional knowledge, and is closely linked to the habitat, as well as cultural, social and physical characteristics of the ecosystems (Altieri, 2009). There appears to be a consensus on the contribution of agroecology to the achievement of food sovereignty, and consequently in

\footnotetext{
${ }^{9}$ To this respect, Tauli-Corpuz further states that "[I]ndigenous concepts are re-emerging that are more comprehensive than development. The concept is called sumak kawsay among the Quichua, suma qamaña by the Aymara, laman laka for the Miskitu, gawis ay biag for the Kankana-ey Igorot, vivir buen/buen vivir in Spanish." (Tauli-Corpuz, 2010, p. xviii).
} 
combating poverty and fostering rural development (Coffey et al., 2007; Espinel, 2010; IshiiEiteman \& Patel, 2009; Nicholls \& Altieri, 2012; Patel, 2009; Toledo, 2012, among others).

United Nations rapporteur Olivier De Schutter (2010), alleges that agroecology emerges from the combination of ecology and agronomy, amalgamating scientific scholarship and practice, but also considers a more holistic worldview and the intrinsic connections between humans and nature. Agroecology seeks to mimic natural processes that occur in nature, so as to create sustainable and resilient production systems, supported by knowledge intensive dynamics (Altieri \& Toledo, 2011; De Schutter, 2010). This is achieved through the application of the following principles and practices: a) crop rotations; b) polycultures; c) integrated resource management; d) natural pest management and use of organic fertility boosters; e) agroforestry as part of the agricultural system; f) utilisation of local varieties of crops and livestock; and, g) improvement of the agrobiodiversity (Holt-Giménez, 2009; De Schutter, 2010; Altieri \& Toledo, 2011). In addition, agroecology involves the pursuit of energetic efficiency and processes that are locally relevant and adapted to each geography, and which need to be "developed on the farmers' knowledge and experimentation" (Altieri \& Toledo, 2011, p. 588). These principles are not only appropriate for protecting the environment, but constitute a form of insurance for farmers, as the development of biodiversity "minimi[zes] risk [...], stabilizes yield over the long term, promotes diet diversity and maximizes return even with low levels of technology and limited resources" (Ibid, p. 591). The Convention on Biological Diversity (CBD) defines diversity as:

the variability among living organisms from all sources including, inter alia, terrestrial, marine and other aquatic ecosystems and the ecological complexes of which they are part; this includes diversity within species, between species and of ecosystems (CBD, n.d., para. 2).

Unlike some of the quality assurance mechanisms of the organic approach, in which the quality certification process has been commodified, thereby benefitting large certification companies and restricting access to peasant communities, the agroecological approach ensures the quality of the products and the production process through Participatory Guarantee Systems. While the practice of these systems is currently embedded in grassroots organisations and requires a strong social fabric, their origins are not grounded in the peasantry, but on the environmental movements in Europe that took place in the 1970s. This framework was the precursor to the regulation of organic production in Europe, which was 
passed in 1991 (Torremocha, 2012). Subsequently, from the 1990s onwards, the quality assurance processes in developing countries, primarily in Latin America and Asia, adhered to the growth of the niche market for certified organic agriculture. This was in order to favour the expansion of the agro-export trend that was flourishing in the markets of Europe, the United States and Japan (Ibid). Unfortunately, this trend was far from benefitting small-scale farmers: for example, in a study conducted among Ecuadorian cacao producers by Melo (2010), it was evident that while the high certification costs were expected to be easily recovered, the lack of bargaining power, the unprivileged position in the cacao value chain, the market fluctuation and the unpredictability of production yields, proved to reduce the benefits to farmers. Some farmers even experienced a significant economic loss. According to Mejia, the evolution of the formal organic certifications, administered by international companies and particularly directed to complying with the demands of large markets, has become a European colonisation process that enriches wealthy nations and international certification companies, at the expense of peasants in developing countries (Torremocha, 2012).

The Participatory Guarantee Systems used in the framework of the agroecological movement are based on the social fabric of the farmers' organisation. Additionally, clear agroecological principles are defined and put into practice through participatory mechanisms in order to guarantee the origin and quality of their produce (RP-FA-1, 2012; RP-FA-2, 2012; RP-NGO1, 2012). Torremocha agrees with Capra's suggestion that this quality assurance process is a "living system" (2012, p. 92, author's translation). Torremocha further correlates the structure of the peasants' participatory guarantee systems with Elinor Ostrom's postulations on the management of social organisations, and suggests that small-scale organisations at the local level, devoted to guarantee their production's quality, concur with Ostrom's theories (Ibid).

However, much more than an environmentally-friendly practice, agroecology is a "social, cultural and political movement" (Toledo, 2012, p. 38, author's translation), that allows for a new agrarian revolution in Latin America and worldwide (Altieri \& Toledo, 2011). The political aspect of agroecology implies a more equitable access to resources, such as "land, seeds, water, credit and local markets", with emphasis on local production for local markets, on the enhancement of farmer-to-farmer cooperation, and on the construction and 
development of a closer relationship between farmers and final consumers (Altieri \& Toledo, 2011, p. 588; Andrango, 2012). This wider and more holistic dimension of agroecology turns it into a hybrid science, which besides its ecological and agronomic character, presents nuances of the principles of "political ecology, ecological economics, environmental history, and ethnoecology" (Toledo, 2012, p. 38, author's translation). Due to the fact that access to land and productive resources is highly political and provokes power struggles, social organisation and the facilitation of a strong social fabric is of the utmost importance (Altieri $\&$ Toledo, 2011).

As explored and presented in this section, agroecology is a science and a set of practices that combines modern and contemporary techniques with traditional practices and alternative epistemologies. It is reinforced by the everyday experience of farmers and represents the way in which communities can achieve food sovereignty. This approach has socio-cultural, economic, environmental and political components, expressed through the various peasant struggles around the world and especially in Latin America. As stated by Altieri and Toledo "[r]ural social movements embrace the concept of food sovereignty as an alternative to the neoliberal approach. [...] Agroecology provides the principles for rural communities to reach food sovereignty but also energy and technological sovereignty within a context of resiliency" (2011, p. 607). Similarly, the special rapporteur on the right to food of the United Nations, Olivier De Schutter, suggests that agroecology addresses not only the right to food, for its effectiveness and applicability is well above conventional agricultural practices, so as to allow for the conservation of the environment while "contribut[ing] to the broader economic development" (De Schutter, 2010, p. 1).

\subsection{Social Cohesion, Political Activism and the Practice of Food Sovereignty Worldwide}

The green revolution and the neoliberal trend have caused various social-environmental conflicts, especially between the urban and rural populations, but also between classes and ethnicities (Kay, 1995). These conflicts have been consolidated through a consensus between the economic and political elites, who have institutionalised the unequal distribution of productive resources and access to environmental services, ultimately leading to 
environmental injustice (González de Molina, 2012, p. 12). As a consequence, people are driven to poverty, while an "ecosystem pathology" is generated through the acceleration of deforestation and other forms of environmental degradation (Ibid, p. 12). Poverty and restricted access to resources leads to the misuse of nature. However, socio-environmental conflicts can also help challenge current institutions and lead to the construction of more sustainable and socially-equitable structures, emerging from the grassroots and social movements (Ibid).

It follows, then, that the production of agroecological goods, without an element of political ecology, is unable to help the quest for a more sustainable development, so restraining the achievement of food sovereignty on a permanent basis. Through the universalization of the farmer to farmer approach and the increased participation of NGOs and civil society movements, social networks have been strengthened, contributing to knowledge sharing and the formation of a powerful political force (Holt-Giménez, 2009). La Via Campesina is the greatest social movement worldwide that advocates for the institutionalisation of food sovereignty and supports peasant initiatives around the globe.

\subsubsection{La Via Campesina - A Global Movement ${ }^{10}$}

La Via Campesina comprises about 150 local and national organizations, [... it] represents about 200 million farmers. It is an autonomous, pluralist and multicultural movement, independent from any political, economic or other type of affiliation (La Via Campesina, 2011, para. 2).

The advocacy institution formed in 1993 by small-scale farmers and farmworkers worldwide, La Via Campesina, was created as a result of a conference led by an international, large-scale farmers association and a Dutch NGO (Holt-Giménez, 2009). ${ }^{11}$ This meeting encouraged dialogue and knowledge sharing between peasants in 70 countries from the African, Asian, American and European continents constituting an international movement that "defends small-scale sustainable agriculture as a way to promote social justice and dignity" (La Via Campesina, 2011). La Via Campesina has become a reference point for other peasant

\footnotetext{
${ }^{10}$ La Via Campesina is a name in Spanish that can be translated to English as "The Peasants' Way" (author's translation).

${ }^{11}$ This large-scale farmers' association was the International Federation of Agricultural Producers (IFAP).
} 
movements worldwide, particularly after launching the concept of food sovereignty at the UN Food World Summit, in 1996 (McMichael, 2008). The works of Rosset (2003), Windfuhr and Jonsén (2005), McMichael (2008, 2009), Patel (2009) and Ishii-Eiteman and Patel (2009), present the different perspectives and motivations that have shaped the conceptualisation of food sovereignty. Despite the contrasting positionalities and discourses around the definition of the concept within the La Via Campesina movement, as discussed by Patel (2009), it seems that there is general agreement about the most important components of the concept: biodiversity, cultural uniqueness, self-determined and holistic development and access to land, water and productive resources.

\subsubsection{The Practice of Food Sovereignty in Latin America}

With the implementation of import substitution industrialisation policies in Latin America, especially during the 1950s and 1960s, the development of the agricultural sector was largely neglected. Due to the allocation of resources to other industries, the consequential limited investment affected the competitiveness and profitability of agricultural activities (Baer, 1972). Additionally, overvalued exchange rates influenced the industrial sector with reduced prices of primary goods, thus directly impacting on farmers' incomes (Ibid). Latin American economies were characterised by high industrial growth, and yet at the same time by a high dependence on primary goods exports, especially during the 1950s and 1960s (Baer, 1972).

Several agrarian reforms were conducted throughout the region as a response to the economic stagnation and income inequalities that were evident in the 1960s (Germani, 1969). The economic liberalisation that followed the 1970s and 1980s, along with the processes of globalisation, modernisation and democratisation led to the appearance of a new social structure, through the emergence of a privileged minority that had access to land and financial resources, in contrast to the weakening of small producers (de David, et al., 2001). The development of the agricultural sector and the pursuit of ever-increasing productivity levels along the Latin American region put additional pressure on small-scale peasant agriculture, threatening the survival of peasant families and their livelihoods, and deepening the levels of poverty in the rural areas (Comunidad Andina, 2011; Grinspun, 2008). In spite of the overwhelming support from governments that industrialised agriculture has received, smallscale agriculture in Latin America continues to be the main source of the region's food supply. This is primarily due to the fact that large-scale agriculture is devoted to the agro- 
export sector to developed countries, altering the agro foods landscape and complicating the availability of locally-produced food for farmers and urban consumers (Watson, 2008; Wittman, 2009). According to a publication of the Andean Region Community (CAN), the small-scale agricultural sector in Latin America contributes around $40 \%$ of the agricultural GDP and more than $60 \%$ of the total rural employment (Comunidad Andina, 2011, p. 8). The latter represents around 120 million people, which is around $20 \%$ of the total Latin American population (World Bank, 2011).

Latin America has become a model of the organisation and agency potential of farmer movements. The region has gone through a unique process enriched by the convergence of different cultures, ethnicities and geographies, as there are around "40-55 million indigenous people speaking about 725 languages" (Altieri \& Toledo, 2011, p. 594). One of the aspects for which the region is well-known is "campesino a campesino movement", 12 which revolutionised the methodologies and conceptions of knowledge sharing and in situ-based research (Holt-Giménez, 2009). In the following paragraphs, the experiences of Central America, Brazil and the Andes will be discussed, providing a comprehensive overview of the main approaches in the region.

\section{Central America and the Caribbean: The Origin of the 'Campesino a Campesino Movement'}

The story begins in the highlands of Guatemala where Kaqchikel farmers visited Mexican farmers in Tlaxcala (Vicente Guerrero), where they had created a school of soil and water conservation. The Guatemalan farmers used parables, stories, and humor to present agricultural improvements to their Mexican compadres [...] [T] hey saw themselves as students, respecting the Mexicans' deep, lifelong knowledge of their own particular land and climate [and both parties] share[d] their new knowledge (Altieri \& Toledo, 2011, p. 601) ${ }^{13}$

The campesino a campesino movement is currently known and practiced worldwide, after starting in 1980 and spreading throughout the Central American region, particularly in Guatemala, Mexico, Nicaragua and Honduras (Altieri \& Toledo, 2011). This methodology relies on the horizontal sharing of knowledge and participatory experimentation lead by a campesino, who promotes the process among his peers (Ibid).

\footnotetext{
12 The word campesino is translated as 'peasant' in English. It is the word used for traditional farmers. Smallscale farming movements in Latin America proudly identify themselves as campesinos.

${ }^{13}$ According to my interpretation, the word compadre in this context shows a respectful and friendly, but at the same time, informal sense of comradeship between farmers in Guatemala and Mexico.
} 
This methodology has proven to be effective also in the Caribbean, particularly in Cuba, where the campesino a campesino movement experienced an interesting development: the economic embargo and the collapse of the Soviet Union forced Cuba to find alternatives to oppression and the consequent menace to its food security and self-reliance (Altieri \& Toledo, 2011). Through the application of sustainable and environmentally-friendly technologies, as well as the implementation of traditional rural agriculture and urban gardens, Cuba could keep moving forward without experiencing a widespread famine (Ibid). Today, the Cuban peasant movement "produce[s] over 65 percent of the country's food, on only 25 percent of the land" (Ibid, p. 600). This proves that sustainable agriculture is an applicable option, even under extreme socio-economic conditions.

\section{Brazil: The MST Movement and the Ecological Management of Soils}

According to Altieri and Toledo (2011), the food sovereignty movement in Brazil is characterised by three aspects: a) the training of farmers, activists and researchers in agroecology; b) the promotion of agroecology as the preferred practice of farmer families; and, c) the facilitation of spaces for debate, political participation and generation of governance alternatives compatible with the philosophy of food sovereignty. The Movimento dos Trabalhadores Rurais Sem Terra (MST) was established in the early 1980s with the aim of promoting rural rights based on access to land and other productive resources (HoltGiménez, 2009). ${ }^{14}$ After failing to address the farmers' needs through the encouragement of the adoption of the industrial agricultural model, the movement changed its strategy to the adoption and promotion of agroecology, achieving wide success and improving the food security and food sovereignty of their members (Ibid). At the same time, Brazil was the birthplace of great exponents of the agroecological sciences: for example Ana Primavesi is known worldwide for her contributions to the research and development of theories related to the "ecological management of soils" (Altieri \& Toledo, 2011, p. 598).

\footnotetext{
${ }^{14}$ The translation from Portugese to English of MST is the 'Movement of Landless Rural Workers' (author's translation).
} 


\section{The Andean Region: Political Activism and Indigenous Organisation}

Social uprisings due to the discontent over economic policies infused with the neoliberal philosophy, especially during the 1990s and 2000s, facilitated and encouraged the social organisation through the construction of community-based networks, with a national outreach (Altieri \& Toledo, 2011). This phenomenon has allowed for the access of community leaders and social activists to holding political office, particularly in Bolivia and Ecuador (Petras, 2008; Postero \& Zamosc, 2004; Yashar, 2005). The assorted geographic and climatic characteristics of the Andes have permitted the development of different but locally adapted agroecological techniques, that have been shared among peasant and indigenous communities (de David et al., 2001).

In this region, the concepts of Peasant Family Farming and more recently the concept of Agroecological Family Farming were born, developed and consolidated (Comunidad Andina, 2011). Due to the conditions in the highlands of the Andean region, that is, limited access to capital and other productive resources, as well as lack of access to other employment sources, peasant communities have maintained the household labour model in which all the members of the family share a great diversity of duties, such as tilling, taking care of the cattle and other small animals, collecting and doing any other household duties (Ibid). Nevertheless, Agroecological Family Farming has a much greater potential than the sole subsistence of the family, as it can be dynamised and strengthened, so as to generate a surplus for sale at a marginal level, in the initial phase, and then as a microbusiness entrepreneurship, in a more advanced phase (Bustos \& Bustos, 2010; Comunidad Andina, 2011).

\subsubsection{The Institutionalisation of Food Sovereignty in Latin America}

The social mobilisation that started to activate during the 1970s and 1980s allowed for the creation of networks of academics and peasants related to food sovereignty and agroecology (Grinspun, 2008). In the 1990s these networks became more solid and complex organisational structures, which then transformed into regional platforms for sharing knowledge and experiences, prompting the dialogue between peasant communities throughout Latin America and the Caribbean. In the following paragraphs, a brief overview of three Latin American 
organisations will be presented, so as to make clear how the institutionalisation of the peasant movements in the region has taken place.

\section{Movimiento Agroecológico para Latinoamérica y El Caribe (MAELA) ${ }^{15}$}

The MAELA movement was formally established in 1992, through the uniting of peasant organisations, small-scale farmers, indigenous groups, rural women's and youth groups, landless movements, advocacy organisations, as well as universities and consumer groups, with the aim of creating proposals for projects related to the consolidation of food sovereignty. This consolidation is aimed to be achieved through the strengthening of the agroecological movement in Latin America and the Caribbean (MAELA, n.d.). According to their website, MAELA has 210 member organisations, representing more than 1,000,000 people, who are working to extend the knowledge and application of agroecological principles (Ibid). The activities of MAELA comprise the organisation of forums and training sessions through the generation of a knowledge dialogue. In 2012 they started a programme of political education in agroecology, to emphasize its link with political ecology and to discuss and reflect on the global governance of agrifood systems (Ibid).

\section{Coordinadora Latinoamericana de Organizaciones del Campo $(C L O C)^{16}$}

The CLOC is the Latin American coordination branch of the global movement La Via Campesina. It was created in 1994, as a result of the awakening of social movements in Latin America, particularly in Bolivia, Brazil, Ecuador, Guatemala, Mexico and Paraguay (CLOC, n.d.). Today, CLOC consists of 84 organisations from 18 countries in Latin America and the Caribbean. This organisation is focused on advocacy and political incidence, raising its voice against government policies that affect the principles of respect to nature and fair treatment of peasants, as well as taking part in social mobilisations in several countries across the region (Ibid). According to their website, the topics that CLOC works on, and advocates for, are: agrarian reform; food sovereignty and [fair] trade; human rights; biodiversity and natural

\footnotetext{
${ }^{15}$ MAELA stands for 'Agroecology Movement for Latin America and the Caribbean' (author's translation).

${ }^{16}$ CLOC stands for 'Latin American Coordinator of Rural Organizations' (author's translation).
} 
resources; sustainable agriculture; gender and youth; migration and labour issues; and, the Cocaleros movement and their rights. ${ }^{17}$

\section{Sociedad Científica Latinoamericana de Agroecología (SOCLA) $)^{18}$}

SOCLA is the scientific arm of the agroecological movement in Latin America, which seeks to support, with scientific evidence, the first-hand experience of peasants in the region. In the same way, SOCLA is committed to receiving feedback and learning from the practical evidence in the field, thereby creating a two-way communication channel between theory and practice (SOCLA, n.d.). SOCLA works with social movements, NGOs and other regional organisations like MAELA and CLOC, offering training programmes about the environmental impact of GM crops and biofuels; climate change and its impacts on smallscale agriculture; and, implications of extractivist agriculture and alternatives to it, among others. The theory and practice approach is manifested through various cooperation agreements with MAELA, other social and advocacy organisations, as well as universities (Ibid).

\subsection{Summary}

This chapter has examined the concept of food sovereignty and agroecology through a comprehensive exploration of the literature. The analysis was not restricted to academic material, but also referred to evidence on the practice and social institutionalisation of food sovereignty, first globally, through the La Via Campesina Movement, and then, in Latin America and the Caribbean. I have elucidated the implications of the conventional extractivist approach to agriculture, focusing on five aspects of analysis: a) climate change; b) intensive use of agro-toxics; c) GM crops; d) hindrances to the nutrition of farming communities; and, e) economic, social and cultural implications for farmers. The greater understanding of food sovereignty has revealed its holistic meaning and its four components: the socio-cultural, economic, environmental and political components, which will be further scrutinised in the

\footnotetext{
${ }^{17}$ For more about the Cocaleros movement, please refer to Domingo (2005), Andersson (2008) and Barrientos (2010).

${ }^{18}$ SOCLA stands for 'Latin American Scientific Society of Agroecology'.
} 
remainder of this dissertation, drawing upon the communities' perspectives. In order to delineate the specificities of food sovereignty in Ecuador, its understandings and ways of practice, the following chapter will contextualise the dynamics in the rural areas, as well as the conditions in which family farming develops. 


\section{Chapter 4}

\section{Agrarian Change and Challenges in Ecuador}

The objective of this chapter is to reveal the characteristics of the rural areas of Ecuador through the analysis of statistical data. The development of the agricultural sector will be addressed by examining its participation in the Gross Domestic Product (GDP). Subsequently, aspects connected with rural social welfare, such as poverty, land tenure structure, and access to water and credit will be reviewed, and will define the framework through which the concept of food sovereignty is currently being explored. By doing so, the reader will be able to identify the challenges that the implementation of food sovereignty signifies for farmers and grassroots movements. The last section of this chapter will introduce the reader to the evolution of the peasants' struggle in Ecuador, and how their resilience has allowed them to maintain and pursue food sovereignty, even amidst the adverse conditions in which family farming develops.

\subsection{Role and Nature of the Agricultural Sector in Ecuador}

In the following paragraphs, the conditions of the rural areas in Ecuador will be exposed through statistical analysis, intertwined with evidence found in recent studies and publications.

\subsubsection{Socio-Economic Importance of Agriculture}

The agricultural sector is an important component of Ecuador's economy. During the 1950s, 1960s and 1970s this sector represented most of Ecuador's GDP. This changed considerably from the mid-1970s onwards due to the oil-boom that left Ecuador immersed in another primary product dependency: crude oil exports. Today, oil extraction and refining activities represent the main income source for Ecuador. Table 4.1 exhibits the percentage share of economic activities in the GDP with decennial information from 1950 to 2007. To access a time-series analysis, the data was taken from the statistical database of the Economic Commission for Latin America and the Caribbean (ECLAC). 
Table 4.1: Composition of Gross Domestic Product (GDP) at Market Prices *

\begin{tabular}{|c|c|c|c|c|c|c|c|}
\hline Economic Activity & 1950 & 1960 & 1970 & 1980 & 1990 & 2000 & 2007 \\
\hline Agriculture, hunting, forestry and fishing & $31 \%$ & $29 \%$ & $24 \%$ & $12 \%$ & $13 \%$ & $11 \%$ & $7 \%$ \\
\hline Mining and quarrying ** & $1 \%$ & $1 \%$ & $0 \%$ & $21 \%$ & $15 \%$ & $22 \%$ & $23 \%$ \\
\hline Manufacturing *** & $17 \%$ & $17 \%$ & $20 \%$ & $9 \%$ & $19 \%$ & $5 \%$ & $2 \%$ \\
\hline Electricity, gas and water & $0 \%$ & $1 \%$ & $1 \%$ & $1 \%$ & $0 \%$ & $1 \%$ & $1 \%$ \\
\hline Construction & $1 \%$ & $2 \%$ & $4 \%$ & $7 \%$ & $4 \%$ & $7 \%$ & $9 \%$ \\
\hline Wholesale and retail trade, restaurants and hotels & $14 \%$ & $16 \%$ & $15 \%$ & $15 \%$ & $21 \%$ & $17 \%$ & $13 \%$ \\
\hline Transport, storage and communications & $5 \%$ & $5 \%$ & $7 \%$ & $8 \%$ & $9 \%$ & $11 \%$ & $10 \%$ \\
\hline Finance, insurance, real estate and business services & $13 \%$ & $13 \%$ & $11 \%$ & $12 \%$ & $6 \%$ & $8 \%$ & $14 \%$ \\
\hline Community, social and personal services & $14 \%$ & $13 \%$ & $16 \%$ & $15 \%$ & $9 \%$ & $11 \%$ & $16 \%$ \\
\hline Subtotal & $97 \%$ & $96 \%$ & $96 \%$ & $99 \%$ & $96 \%$ & $92 \%$ & $95 \%$ \\
\hline Less: financial intermediation services indirectly measured & $1 \%$ & $1 \%$ & $2 \%$ & $3 \%$ & $2 \%$ & $2 \%$ & $3 \%$ \\
\hline Plus: taxes and duties on imports excluding VAT & $4 \%$ & $5 \%$ & $5 \%$ & $4 \%$ & $5 \%$ & $10 \%$ & $7 \%$ \\
\hline PIB Total: Gross Domestic Product & 7,229 & 14,071 & 35,019 & 293,337 & $8,204,2$ & 15,933, & 45,789 , \\
\hline
\end{tabular}

Elaboration: Author

Source: ECLAC (n.d.-a)

* The information used for this analysis is at current prices. For 1950-1993, figures are expressed in millions of sucres. From 1993 onwards the figures are expressed in thousands of dollars.

** For 1950-1970, includes petroleum refining. The Central Bank of Ecuador classifies this activity under the heading Crude petroleum and natural gas, which comes under Major Division Mining and Quarrying of ISIC, Rev.2. From 1970 onwards, in the interests of comparability between countries, ECLAC has incorporated refining within Major Division Manufacturing.

*** For 1950-1970, petroleum refining is included under mining and quarrying. 
As seen above, the most significant variations in the participation in the GDP occur in the areas of agriculture, mining and manufacturing. The participation of agriculture has dropped considerably, going from $31 \%$ in 1950 to only $7 \%$ in 2007. In contrast, mining has gone from having participation of only $1 \%$ to $23 \%$ during the same period. Manufacturing also shows a significant change, with a reduction in the participation in GDP of 15 percentage points over the last six decades. To look further at the variations of these three economic activities, Figure 4.1 displays the graphical representation of their evolution, over a period of 57 years.

Figure 4.1: Evolution in the Participation of Agriculture, Manufacturing and Mining in total GDP (1950 - 2007)

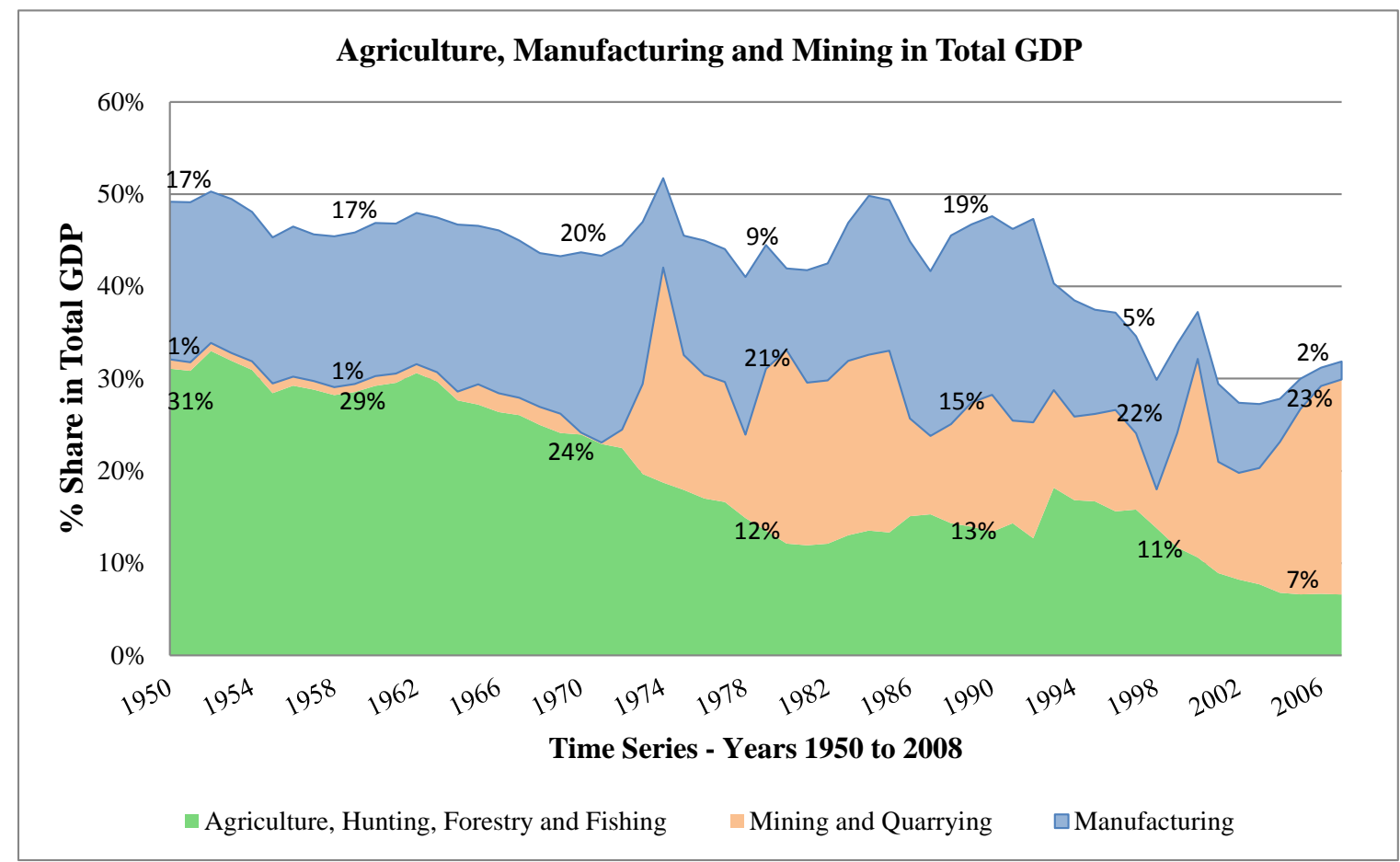

Elaboration: Author

Source: ECLAC (n.d.-a)

The graph above shows that the participation of agriculture in the Ecuadorian economy began to drop substantially from 1970 onwards, due to the onset of oil exploitation in the country. Manufacturing activities conversely, have had a more volatile and less consistent behaviour, fluctuating between $17 \%$ and $19 \%$ until the early 1990 s, and subsequently dropping to $2 \%$ of participation in the GDP. 
The economic information presented in 2011 by the Central Bank of Ecuador (BCE), differs greatly from that presented by ECLAC and only provides data from the last decade. I was interested in looking at the drastic variations in the behaviour of agriculture at the macrolevel, as well as the changes that the venture in crude oil exploitation signified to the other sectors of the economy. . In order to maintain consistency in the data analyses, I chose to refer only to the ECLAC database. Nevertheless, for completion, Table 4.2 presents official information on the participation of four sectors of the economy in the GDP, from 2000 to 2011: agriculture, hunting and forestry; oil and mining; petroleum refining; and manufacturing.

Table 4.2: Participation of Agriculture, Oil and Mining, Petroleum Refining and Manufacturing in Ecuador's GDP, According to the Central Bank of Ecuador (2000 2011)

\begin{tabular}{|c|c|c|c|c|c|}
\hline Year & $\begin{array}{c}\text { Agriculture, } \\
\text { Hunting and } \\
\text { Forestry }\end{array}$ & Oil and Mining & $\begin{array}{c}\text { Petroleum } \\
\text { Refining }\end{array}$ & $\begin{array}{c}\text { Manufacturing } \\
\text { (except oil } \\
\text { refining) }\end{array}$ & $\begin{array}{c}\text { TOTAL } \\
\text { GDP } \\
\text { (USD) }\end{array}$ \\
\hline 2000 & $13 \%$ & $5 \%$ & $4 \%$ & $18 \%$ & 18.318 .601 \\
\hline 2001 & $11 \%$ & $3 \%$ & $3 \%$ & $16 \%$ & 24.468 .324 \\
\hline 2002 & $10 \%$ & $3 \%$ & $3 \%$ & $15 \%$ & 28.548 .945 \\
\hline 2003 & $10 \%$ & $4 \%$ & $3 \%$ & $13 \%$ & 32.432 .859 \\
\hline 2004 & $9 \%$ & $6 \%$ & $2 \%$ & $13 \%$ & 36.591 .661 \\
\hline 2005 & $8 \%$ & $9 \%$ & $2 \%$ & $12 \%$ & 41.507 .085 \\
\hline 2006 & $8 \%$ & $11 \%$ & $1 \%$ & $12 \%$ & 46.802 .044 \\
\hline 2007 & $8 \%$ & $12 \%$ & $2 \%$ & $12 \%$ & 51.007 .777 \\
\hline 2008 & $8 \%$ & $14 \%$ & $2 \%$ & $12 \%$ & 61.762 .635 \\
\hline 2009 & $8 \%$ & $9 \%$ & $2 \%$ & $12 \%$ & 61.550 .427 \\
\hline 2010 & $8 \%$ & $12 \%$ & $1 \%$ & $12 \%$ & 67.856 .493 \\
\hline 2011 & $8 \%$ & $13 \%$ & $1 \%$ & $12 \%$ & 78.188 .929 \\
\hline
\end{tabular}

Elaboration: Author

Source: BCE (2012a)

According to the BCE information, the Agricultural sector currently represents $8 \%$ of the GDP. The greatest divergence between the data from ECLAC and the BCE is seen in Mining and Quarrying, which according to ECLAC, represent 23\% of the GDP for year 2006, versus $12 \%$ according to the BCE. Likewise, according to ECLAC, the category of Manufacturing is only $2 \%$ of the GDP in 2006, while the BCE presents a figure of $12 \%$ for the same year. Both the ECLAC and BCE data show a decreasing rate for agriculture, but Carrion and Herrera 
(2012) note that if the Gross Value Added (GVA) of agriculture is considered at a constant 2000 US dollars, ${ }^{19}$ the relative weight of the agricultural sector and its growth rate have increased since the $1980 \mathrm{~s}$. The latter shows that the levels of production of the agricultural sector have indeed increased, but the related financial benefits have nurtured the intermediary sector. Moreover, the increased value of the intermediate consumption could have resulted in inflated prices of farming products for the final consumer.

Beyond the relevance of agriculture for the macro economy, small-scale agriculture is of the utmost importance for Ecuadorian households. Between $51 \%$ and $75 \%$ of the total provision of food for families comes mainly from small-scale farming. In addition, Agricultural Production Units (APUs) between one and two hectares (ha) represent $43 \%$ of the total number of APUs,${ }^{20}$ and control only $6 \%$ of the land (Comunidad Andina, 2011; INEC, 2000). However, the sector that has grown the most in recent years is the agricultural segment assigned to the agroindustry and agro exports, putting small-scale peasant agriculture aside and jeopardising its maintenance (Carrión \& Herrera, 2012; Comunidad Andina, 2011). Ecuador's agricultural trade balance is positive, mainly because of the high surplus of some star agricultural products for export (for example, bananas, cacao, coffee and flowers). Despite this, there is a shortage of a number of products for internal consumption such as cereals, particularly wheat, barley and oats; fruits, particularly apples; as well as oils, meat, milk and dairy products (Carrión \& Herrera, 2012).

Additionally, small-scale agriculture also faces disadvantageous conditions in the market, as " $40 \%$ of the retail market (household consumption) is managed by large supermarkets, [...] which obtain their products from few suppliers", leaving peasant farmers aside and giving preference to intermediaries, (Comunidad Andina, 2011, p. 38, author's translation). It is estimated that around " $70 \%$ of [Ecuadorian] families [...] buy [their groceries] in one of the largest supermarket chains" (Ibid, p. 38, author's translation). As noted by Burgos (in Carrión \& Herrera, 2012), the inequitable intermediary system has its roots in the colonial and

\footnotetext{
${ }^{19}$ According to the OECD Glossary of Statistical Terms, "gross value added is the value of output less the value of intermediate consumption; it is a measure of the contribution to GDP made by an individual producer, industry or sector; gross value added is the source from which the primary incomes of the SNA are generated and is therefore carried forward into the primary distribution of income account." (OECD, 2001).

${ }^{20}$ Refer to page 22
} 
republican periods, where mestizo groups would remove by force the produce of the indigenous farmers, preventing them from relating directly with consumers. These groups also accumulated profits at the intermediary level, affecting not only the peasant economy but also raising the prices to consumers. As seen in the previous analysis, the main function of commercial brokerage for farming products, which should "bring products closer to consumers [and] optimize costs", is not currently being fulfilled (Ibid, p. 103, author's translation).

\subsubsection{Rural Poverty in Ecuador}

Levels of poverty in Ecuador are considerably higher in rural than in urban areas. According to the National Institute of Statistics and Censuses of Ecuador (INEC), the poverty line for the year to December 2006 was estimated at a monthly income of US\$57.29; and at US\$31.92 for extreme poverty. While methods for calculating poverty and their outcomes vary substantially, the three methodologies utilised by INEC will be part of the following analysis. The information disclosed by INEC refers to the methods of income, consumption and unsatisfied basic needs (UBN). For the period between 1995 and 2006, the information was generated by the consumption and UBN methods, whereas from 2006 onwards, the method utilised was based on income. This inconsistency with methods did not allow for the analysis of the evolution of poverty between 1995 and 2011. However, combining the three methods, Figure 4.2 allows observation of the variations in the levels of poverty in the period mentioned. 
Figure 4.2: Rural Poverty in Ecuador - Consumption, Unsatisfied Basic Needs (UBN) and Income Methods

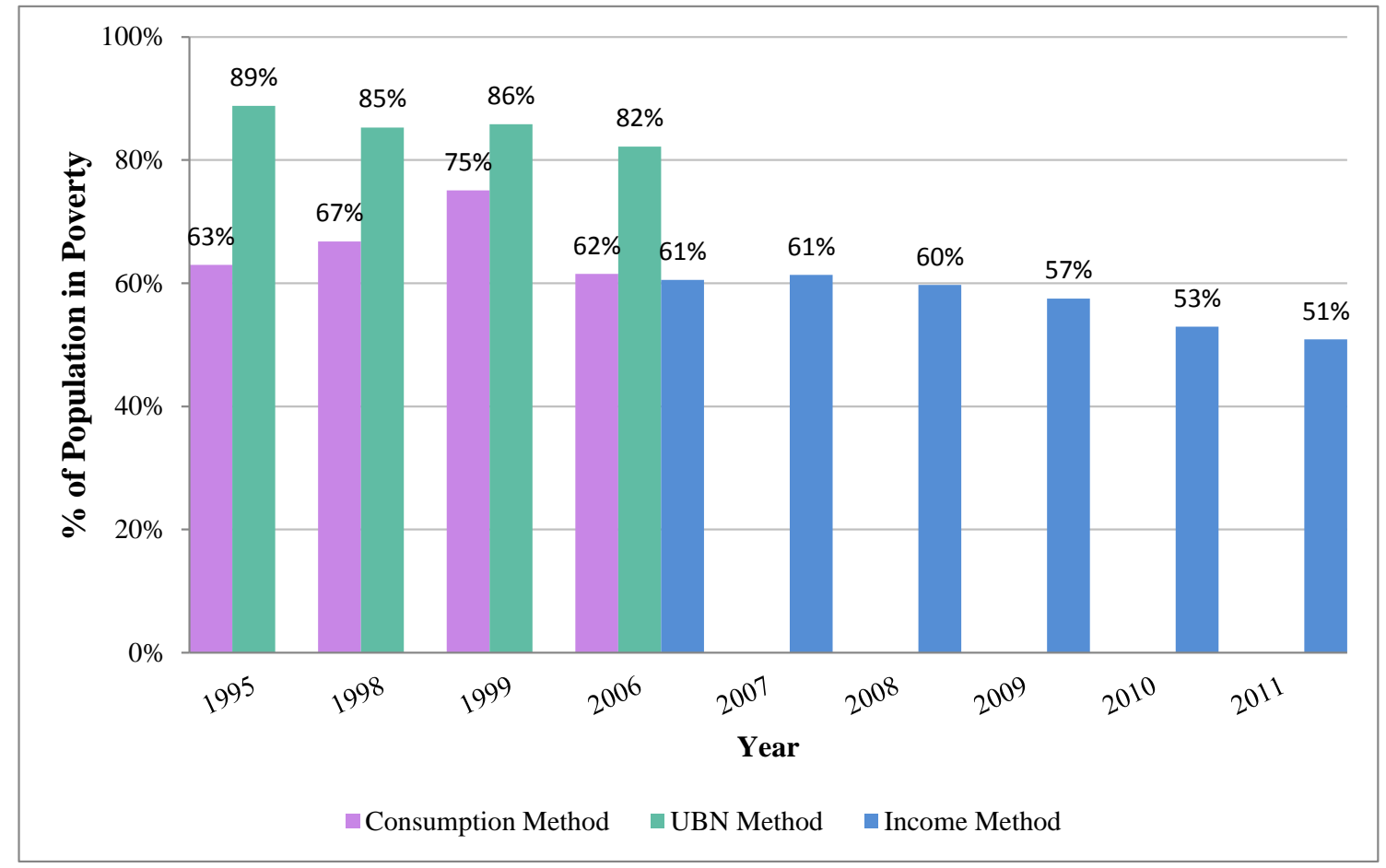

Elaboration: Author

Source: INEC (n.d.)

As seen in Figure 4.2, the results between the consumption and UBN approaches differ significantly, namely between 11-26 percentage points. It is not my intention to rehearse at the effectiveness and applicability of these three methods, as several authors have explored this matter (Lipton \& Ravallion, 1995; Streeten \& Burki, 1978; Thurow, 1967; Townsend, 1971, 1993). However, it is worthwhile noting that most criticism is directed to the income approach, regarding its lack of representation of the real needs of households, their consumption power, and access to resources (ECLAC, 2009; Ortiz Davidson, et al., 2004). Additionally, the information supplied solely by income methods does not provide evidence that can identify the causes of poverty (ECLAC, 2009). UBN and other multidimensional poverty methods are regarded as a more appropriate alternative to identifying levels of poverty, their inherent causes, and its effects on the population (ECLAC, 2009; Ortiz Davidson, et al., 2004). In order to depict the poverty differences in the urban and rural areas, Figure 4.3 displays this information according to the income method. 
Figure 4.3: Urban Versus Rural Poverty - Income Method

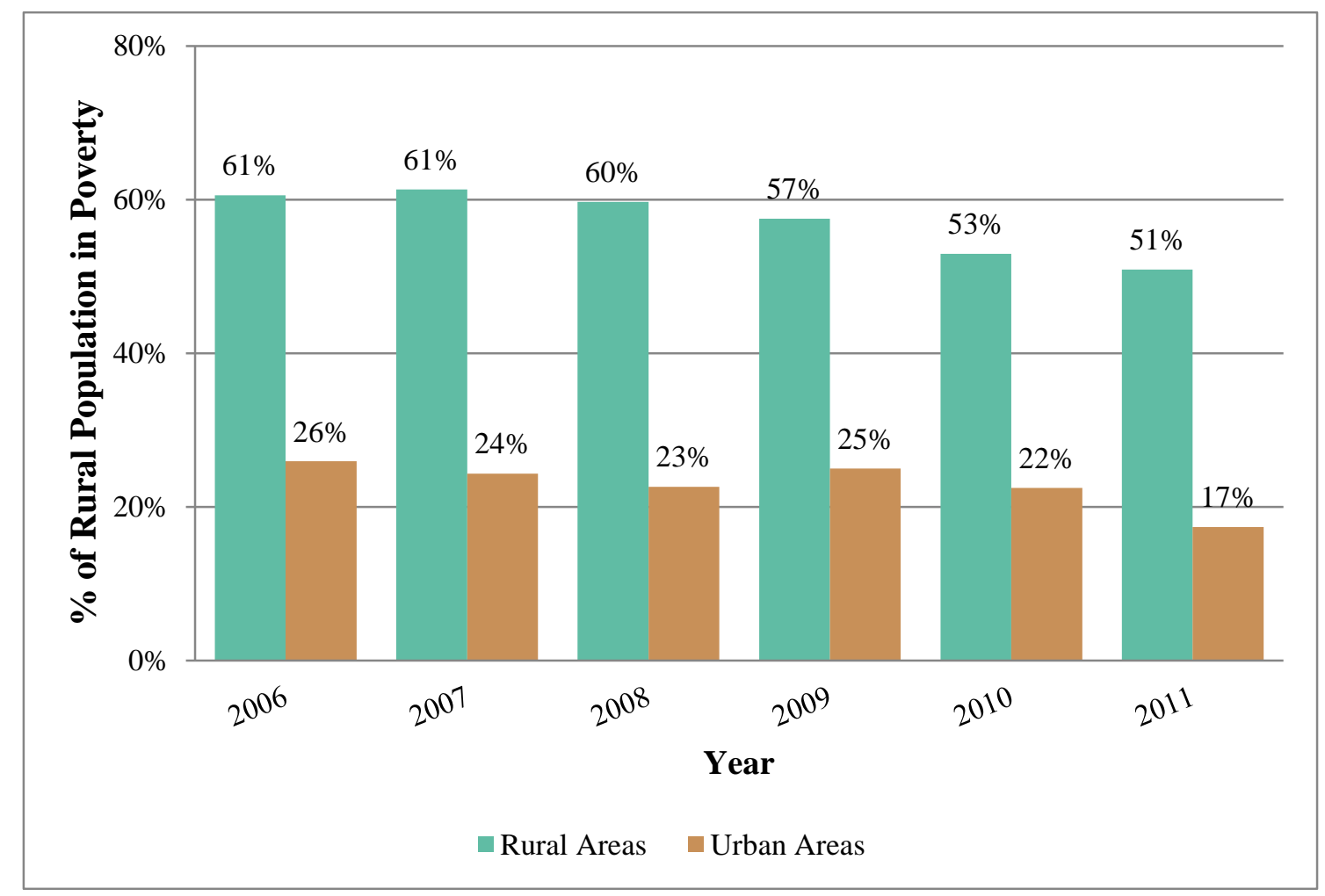

Elaboration: Author

Source: INEC (n.d.)

Figure 4.3 shows that in both a relative and absolute sense, poverty in rural areas is significantly higher than in urban areas, with a difference of over $35 \%$ in every year between 2006 and 2011. Considering that approximately $37 \%$ of the population live in the countryside, the rural poor represented almost 3,000,000 in 2011, compared with less than 1,000,000 in the cities. The hardships of the rural areas have motivated a massive emigration to the cities. According to a study conducted by the Andean Community Secretariat (Comunidad Andina, 2011), within a period of 10 years (between 1990 and 2001), at least 6\% of the rural population migrated to the cities.

\subsubsection{Land Tenure Structure}

According to the last National Agricultural Census held in 2000, there are 842,882 Agricultural Production Units (APUs) throughout the country, which represent 12,355,830 hectares (ha). The agricultural frontier has augmented dramatically over the last 50 years; in 1954, the area employed for farming activities was 5,999,700 ha and according to the data 
from 2000, that area had more than doubled (Carrión \& Herrera, 2012; INEC, 2000; Larrea, 2008). As forest cover is minimal compared to 1938 levels, and more than $41 \%$ of protected areas have suffered some type of intervention; this phenomenon has not only affected the environment, but has also perpetuated land dispossession of indigenous and peasant communities (Larrea, 2008). Table 4.3 permits examination of the structure of land tenure in Ecuador, according to the number of APUs and the total hectares of land available for each APU.

Table 4.3: Structure of Land Tenure in Rural Areas of Ecuador

\begin{tabular}{|l|c|c|c|}
\hline \multicolumn{1}{|c|}{$\begin{array}{c}\text { Size of the } \\
\text { APU }\end{array}$} & $\begin{array}{c}\text { Number of } \\
\text { APUs }\end{array}$ & $\begin{array}{c}\text { Total } \\
\text { Hectares }\end{array}$ & $\begin{array}{c}\text { Hectares per } \\
\text { Type of APU }\end{array}$ \\
\hline Less than 1 ha & 248,398 & $1 \%$ & 95,834 \\
\hline $1<2$ ha & 117,660 & $1 \%$ & 156,016 \\
\hline $2<3$ ha & 78,850 & $1 \%$ & 183,354 \\
\hline $3<5$ ha & 90,401 & $3 \%$ & 339,021 \\
\hline $5<10$ ha & 101,066 & $6 \%$ & 688,987 \\
\hline $10<20$ ha & 75,660 & $8 \%$ & $1,017,807$ \\
\hline $20<50$ ha & 12,941 & $13 \%$ & $2,372,027$ \\
\hline $50<100$ ha & 34,498 & $18 \%$ & $2,242,409$ \\
\hline $100<200$ ha & 76,792 & $19 \%$ & $1,666,879$ \\
\hline More than 200 & 6,616 & $29 \%$ & $3,593,496$ \\
\hline TOTAL & $\mathbf{8 4 2 , 8 8 2}$ & $\mathbf{1 0 0 \%}$ & $\mathbf{1 2 , 3 5 5 , 8 3 0}$ \\
\hline
\end{tabular}

Elaboration: Author

Source: INEC (2000)

Table 4.3 shows the inequalities in land tenure structure: 248,398 APUs (which represent almost $30 \%$ of the total number of APUs) have access to only $1 \%$ of the total hectares assigned to farming activities, while only 6,616 APUs (about $0.7 \%$ of the total number of APUs) have access to $29 \%$ of the land. Moreover, $16 \%$ of the properties, which are 20 ha large or more, occupy $80 \%$ of the land. The remaining $84 \%$ of properties, which represent 712,035 APUs are left with only $20 \%$ of the land. Figure 4.4 displays a comparison between the number of APUs and the correspondent land size, through a graphical representation of the unequal conditions related to rural properties. 
Figure 4.4: Rural Property Structure - Year 2000

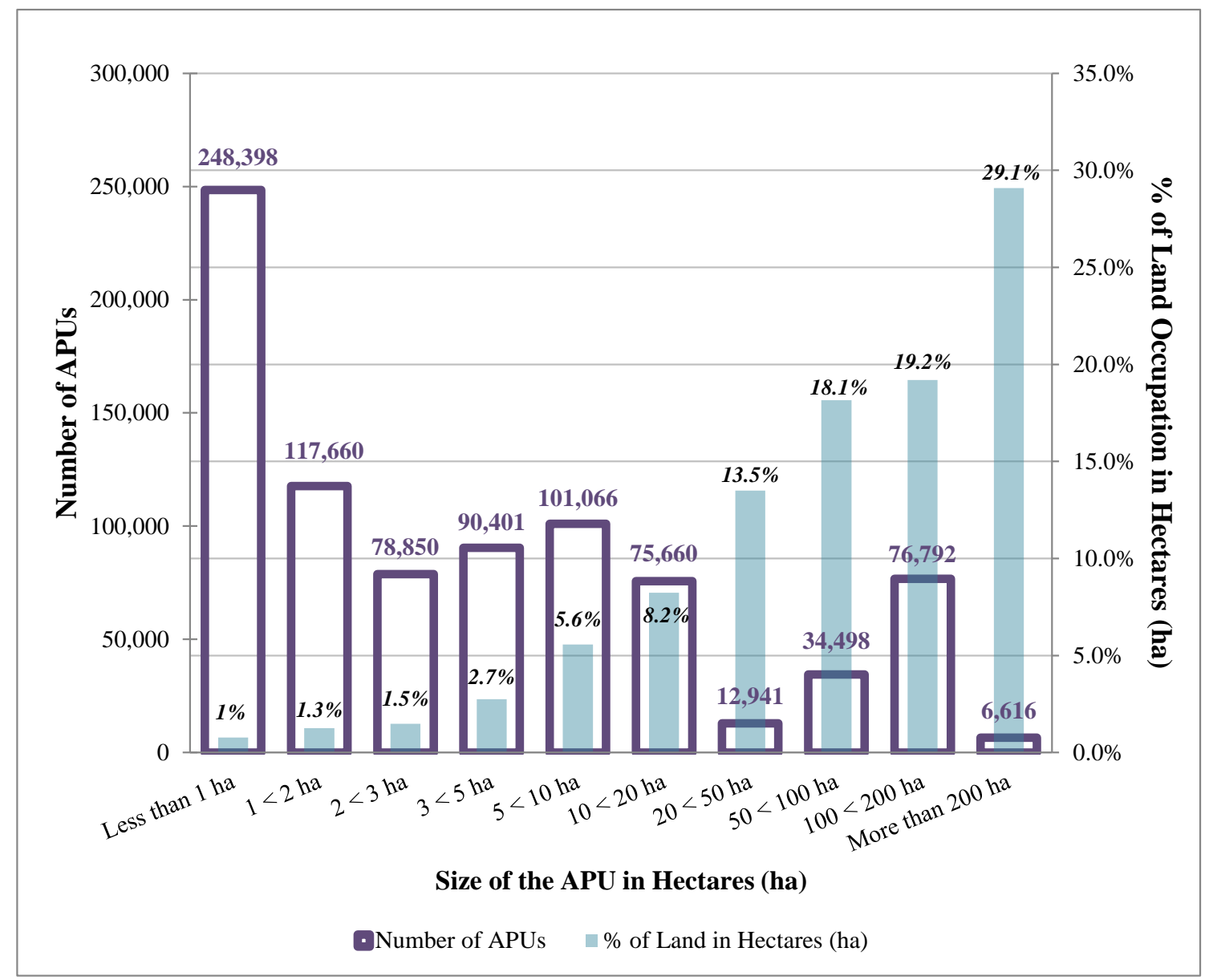

Elaboration: Author

Source: INEC (2000)

The Gini Index for land distribution in Ecuador is around 0,8 and has varied little over the last 50 years (Carrión \& Herrera, 2012). ${ }^{21}$ According to Larrea (2008) Ecuador is one of the countries in Latin America with the most inequalities related to land distribution. There have been two formal agrarian reforms and various attempts to colonise the Ecuadorian Amazon rainforest in order to grant land access to small farmers (from the Sierra and Coastal regions). However, rural tenure structures remain inaccessible to farming communities (Ibid).

\footnotetext{
${ }^{21}$ According to the OECD glossary of statistical terms, Gini index "measures the extent to which [...] distribution $[\ldots]$ among individuals [...] within an economy deviates from a perfectly equal distribution. [...] A Gini index of zero represents perfect equality and 100 [or 1], perfect inequality" (OECD, 2006).
} 
As stated by Valenzuela, inequality is perpetuated by the pattern of economic accumulation, currently in force, and is intensified by the socio-historical particularities of Latin American societies (Carrión \& Herrera, 2012). In the case of Ecuador, the aftermath of the colonisation process and the power structures established in the republican period, have generated a pattern of race and class discrimination, neglect of peasants and indigenous rights, and extractive exploitation of natural resources. As a consequence, production relations are developed at the expense of human, social, environmental and cultural capital. Trade dynamics are also continually transferring economic benefits from the weakest sectors of the society to the most powerful ones, thus perpetuating class and power relations (Ibid). This phenomenon is evident particularly in the field of production and marketing of farming goods. Furthermore, the structure of the informal market system until the late 1980s was unfair and offensive to farmers, particularly if they were indigenous. The mestizo population dominated the bargaining process: they sought to reduce product prices as much as possible, putting the money offered inside the farmers' pockets, and thereby forcing them to accept whatever little money was offered in exchange for their products (Ibid). After the indigenous mobilisations of the early 1990s, "that [behaviour was] socially condemned and so, there [was some] social pressure for it to disappear" (Carrión \& Herrera, 2012, p. 100, author's translation).

\subsubsection{Access to Water and Credit}

According to Carrión and Herrera (2012), small-scale farmers, whose APUs are smaller than 10 ha of land, have access limited water and are able to irrigate only $26 \%$ of the total area on their properties. Conversely, APUs that are 50 ha or larger represent $6 \%$ of the total APUs, occupy $60 \%$ of the land and have access to irrigation for $51 \%$ of their properties (Ibid). Additionally, the cost of irrigation differs greatly between small and large producers. Vara argued that "a banana company pays between US $\$ 0.05$ and US $\$ 0.4$ for irrigation, for every US $\$ 100$ that it earns, whereas peasant farmers spend between US\$1.2 and US\$30 for every US\$ 100 of earning” (Ibid, p. 94, author's translation). In terms of access to credit, peasant economies have a small saving capacity and unfortunately very limited access to credit in the formal banking sector. Table 4.4 offers a detailed view of funding structures currently available for farmers. 
Table 4.4: Funding Structure for Farming Activities

\begin{tabular}{|c|c|c|c|c|c|c|}
\hline $\begin{array}{c}\text { Main Source of } \\
\text { Credit }\end{array}$ & $0<10$ ha & $\begin{array}{c}10<20 \\
\text { ha }\end{array}$ & $\begin{array}{c}20<100 \\
\text { ha }\end{array}$ & $\begin{array}{c}100<200 \\
\text { ha }\end{array}$ & $>200$ ha & TOTAL \\
\hline \multirow{2}{*}{ Private Banking } & 2,562 & 736 & 1,547 & 429 & 374 & 5,647 \\
\hline & $6 \%$ & $10 \%$ & $16 \%$ & $28 \%$ & $41 \%$ & \\
\hline \multirow{2}{*}{$\begin{array}{c}\text { National } \\
\text { Development Bank }\end{array}$} & 3,423 & 1,656 & 3,680 & 693 & 315 & 9,766 \\
\hline & $8 \%$ & $22 \%$ & $37 \%$ & $45 \%$ & $35 \%$ & \\
\hline \multirow{2}{*}{ Credit Union } & 8,134 & 925 & 1,036 & 97 & 36 & 10,227 \\
\hline & $19 \%$ & $13 \%$ & $11 \%$ & $6 \%$ & $4 \%$ & \\
\hline \multirow{2}{*}{$\begin{array}{l}\text { Inputs Provider } \\
\text { (Grace Period) }\end{array}$} & 711 & 259 & 374 & 45 & 37 & 1,426 \\
\hline & $2 \%$ & $4 \%$ & $4 \%$ & $3 \%$ & $4 \%$ & \\
\hline \multirow{2}{*}{ Industrial Company } & 2,013 & 283 & 302 & 35 & 18 & 2,651 \\
\hline & $5 \%$ & $4 \%$ & $3 \%$ & $2 \%$ & $2 \%$ & \\
\hline \multirow{2}{*}{ Money Lenders } & 12,328 & 1,899 & 1,215 & 67 & 16 & 15,525 \\
\hline & $29 \%$ & $26 \%$ & $12 \%$ & $4 \%$ & $2 \%$ & \\
\hline \multirow{2}{*}{ Intermediary } & 2,878 & 617 & 474 & 27 & 19 & 4,016 \\
\hline & $7 \%$ & $8 \%$ & $5 \%$ & $2 \%$ & $2 \%$ & \\
\hline \multirow{2}{*}{ Relatives } & 4,957 & 508 & 423 & 23 & 10 & 5,922 \\
\hline & $12 \%$ & $7 \%$ & $4 \%$ & $1 \%$ & $1 \%$ & \\
\hline \multirow{2}{*}{$\begin{array}{c}\text { Foundations or } \\
\text { NGOs }\end{array}$} & 2,918 & 297 & 389 & 36 & 51 & 3,692 \\
\hline & $7 \%$ & $4 \%$ & $4 \%$ & $2 \%$ & $6 \%$ & \\
\hline \multirow{2}{*}{ Other Sources } & 2,476 & 192 & 389 & 91 & 34 & 3,181 \\
\hline & $6 \%$ & $3 \%$ & $4 \%$ & $6 \%$ & $4 \%$ & \\
\hline TOTAL & 42,400 & 7,372 & 9,829 & 1,543 & 910 & 62,053 \\
\hline
\end{tabular}

Elaboration: Author

Source: INEC (2000)

As it can be noted, the main sources of credit for farmers owning APUs that are 20 ha or more are the private banking and the National Development Bank (BNF). In contrast, farmers owing an APU between 10 and 20 ha resort mainly to the BNF and to money lenders. Finally, in the case of small-scale farmers who own an APU of less than 10 ha, the sources of credit, which they recur to, are money lenders, credit unions and relatives. The funding structure is clearly designed to benefit medium and large-scale farmers, pushing small farming communities to the informal banking sector. 


\subsection{Evolution of the Peasant Struggle: Organisational Strengthening and Resilience}

Over time, the institutionalisation of inequality against peasant livelihoods encouraged deeper levels of organisation among indigenous communities of the Sierra, which historically had been characterised by high levels of social cohesion, especially through the Ayllu system (Andolina, et al., 2005; Beitcher, 2012). ${ }^{22}$ The absence of the State in rural areas motivated the proliferation of NGOs in the countryside, which again reinforced the importance of the social and institutional strengthening of farming communities (Martínez, 2008). This proliferation occurred mainly during the 1980s, as a result of the application of Structural Adjustment Programmes in Ecuador (Solo de Zaldívar, 2008a). Indeed, NGOs and unions replaced the role of the State for the development of the rural sector, known as the practice of Another Development (AD), characterised by a grassroots, highly participatory dynamic (J. Petras \& Veltmeyer, 2001, p. 86). Unfortunately the increased number of NGOs resulted in a myriad of approaches, many of which were opposed to each other (Martínez, 2008; Solo de Zaldívar, 2008) The main approach during the 1980s and 1990s was focused on organisational strengthening. However, the globalisation and trade liberalisation approaches influenced not only public policies in Ecuador, but also the orientation of NGO's. Accordingly, NGOs adjusted their programmes to fit into the market-oriented trend of the 2000s (Ibid). In spite of this shift in their approach, the work done during the previous decades had an influence on social fabric formation that, combined with the agency of indigenous leaders, led to the mobilisation of peasants' organisations. One of the centres of formation of first and second level communitarian organisations was the province of Chimborazo, in the Sierra region (Solo de Zaldívar, 2008a). This and other representations of communitarian organisation favoured cohesion in the rural sector, which became widespread throughout the different regions of Ecuador.

This process of social fabric formation, as well as the expression of the farmers' and indigenous communities' complaints, was relatively peaceful and set a precedent in the region

\footnotetext{
${ }^{22}$ The Ayllu system refers to "Andean indigenous communities of extended families, cargo-based leadership patterns, and occupation of specific territorial spaces" (Andolina, et al., 2005, p. 679). The characteristics of Ayllus entail "self-sustaining family networks that function through reciprocity and shared collectives on commonly held lands" (Beitcher, 2012, p. 20)
} 
(North, et al., 2008). Unlike the situation in the neighbouring countries of Peru and Colombia, where armed conflicts with Sendero Luminoso and the Revolutionary Armed Forces of Colombia (FARC) broke out, the Ecuadorian situation was characterised by the achievement of results through negotiation, and "seemed an island of peace amid the turmoil in the region" (Ibid, p. 147, author's translation). Nevertheless, severe human rights abuse took place during the 1980s and 1990s, during the administrations of Presidents León Febres Cordero, Rodrigo Borja and Sixto Durán Ballén (Ibid). In fact, the peasant struggle had great opposition from landowners and the government. Between 1985 and 1998, the Ecumenical Human Rights Commission (CEDHU) registered "389 deaths at the hands of police, military force and gangs of armed thugs hired [by private parties]" (Ibid, p 147, author's translation). In addition, the Land Conflicts Council identified 317 land disputes from 1990 to 2001 (Ibid). As stated by Kay, this repression was "aimed at preventing the empowerment of the subaltern classes" (in North et al., 2008, p. 149, author's translation). Despite this, the struggle continued, and the organisational efforts succeeded in influencing the political situation, pushing for the implementation of agrarian policies and consolidating the farmers and indigenous organisation throughout the country.

Under these conditions of neglect, dispossession and oppression, small-scale agriculture could only survive through the social organisation and the application of techniques that allowed them to preserve the limited resources to which peasants had access to. These included limited land tenure, land with marginal productivity, lack of irrigation and limited access to credit. There are no national statistics about the number of farmers who cultivate their lands with the agroecological approach, but a comprehensive study conducted by the Andean Community Secretariat (CAN), found many small-scale farmers in Ecuador, who still practice traditional techniques, avoid the utilisation of agro-toxics, and have converted their practices to the agroecological approach (Comunidad Andina, 2011). All of the agroecological farms studied by the CAN have put into practice diverse methods for the management and conservation of the soil, through physical and biological techniques. The study found that agroecological farms in the Sierra region have a higher level of sustainability than farms in the Coastal region, probably due to the social cohesion of families in the Sierra, as well as the surrounding conditions; agroecological farms on the Coast are adjacent or close to monocultures, which are highly dependent on external inputs (Ibid). 
Finally, it is worthwhile mentioning that there is a large potential for the development of the agroecological market in Ecuador, as, according to the CAN study (2011), 59\% of households showed interest in consuming agroecological or organic products in the future. The study also found that only $7 \%$ of the population knows what an agroecological product is, and $5.2 \%$ of the total population claims to consume agroecological or organic products. Twenty-three percent of the total of households that consume organic products mentioned that the principal reason for this behaviour is, they believe organic products are healthier, and $44 \%$ claimed that while they are keen to consume such products, their availability in the retail market is very limited (Comunidad Andina, 2011).

\subsection{Summary}

This chapter has examined the conditions that frame agricultural activities in Ecuador. Firstly, we have seen that the participation of agriculture in the GDP has fallen considerably in the last six decades. Notwithstanding this decline at the macro-economic level, in microeconomic terms, family farming is the main source of income for millions of farmers and provides most of the food basket items to Ecuadorian families. Rural communities face difficulties accessing productive land, which is exacerbated by the high levels of poverty, and lack of access to other productive resources, such as water and credit. In spite of these adverse conditions, communitarian leadership and the strengthening of social mobilisation have allowed farmers to maintain their traditional practices and implement agroecological techniques. This wide contextualisation will form the basis for the deepening in the Ecuadorian case, through the elucidation of the governance framework of food sovereignty in Chapter 5. 


\section{Chapter 5 \\ The Governance of Food Sovereignty in Ecuador}

This chapter will present a comprehensive perspective of the current challenges for the governance of food sovereignty in Ecuador. Firstly, it will briefly lead the reader through a historical exploration of the events that led to the so-called turn to the left in the Latin American region. Subsequently, it will present the current political perspective in Ecuador, after the emergence of the Sumak Kawsay and its adoption into the government's political discourse and intervention rationale. The third section of the chapter will characterise the structure for rural governance in Ecuador, drawing on the analysis of laws and other formal documents that have emerged in recent years. The final section will assess the governance framework related to food sovereignty, focusing on five aspects that have a significant impact on the achievement of food sovereignty. By doing so, this chapter will address the second research objective.

\subsection{Historical Context of the Resurgence of the Left in Latin America}

One of the most influencing events that has impacted the current socio-cultural and political situation in Latin America was the Cold War. The 40 years of political, economic and technological rivalry between the United States and the Soviet Union was marked by an intense involvement in political and military conflicts in developing countries, which in turn prompted the radicalisation of ideological stances within Latin America and other parts of the world (Murray, 2006). Most of Latin America was considered an area of influence of the United States' power (Carbone, 2006). However, the United States' foreign policy had not only ideological motivations, but also economic implications. The North American strategy included the provision of financial, political and logistical support to countries that had liberal democratic policies, or where communist opposition existed, forging the establishment of a counter power in the region (Ibid).

The Alliance for Progress in Latin America, implemented during the 1960s conveyed an increase in the financial support from the United States to democratic governments in Latin 
America, under the condition of encouraging the flow of foreign investments and protecting democracy (Murray, 2009). Subsequently, the United States' foreign policy was centred on the implementation of Structural Adjustment Programmes (SAP), particularly during the 1970s, 1980s and 1990s (Murray, 2009). According to Castañeda, "free-market policies, wide-open trade and investment approaches, and total reliance on the private sector came to be seen as a foolproof recipe for economic success in Latin America" (1990, p. 480). While SAPs had positive impacts on the export agro-industry, they had a devastating effect on small-scale farming, principally due to land hoarding (Murray, 2008).

After the collapse of the Soviet Union, the remaining communist regimes around the world lost strength and influence, and in turn Washington's foreign strategy focused on the ideological consolidation of democracy and neo-liberal globalisation through increasing trade agreements, foreign investment campaigns and economic sanctions to leftist governments (Murray, 2006). However, the terrorist attacks of September of 2001 transformed the political and diplomatic milieu, turning the focus on security and the War on Terror, which were materialised through the American interventions in Iraq (Ibid). Concurrently, social concern regarding increased poverty, social inequality and political-economic instability throughout the region consolidated the formation of the Anti-Globalisation and the Global Justice movements, from the 1990s onwards (Murray, 2006; Waterman, 2007). The latter generated the conditions for the appearance of a left-infused current in Latin America.

Twenty-first Century Socialism emerged in the aforementioned climate, with characteristics that resemble more of a neo-structural, than a purely left-wing approach. The term was initially introduced by the academic Heinz Dietrich in year 2000, and subsequently coined and consolidated by the late Venezuelan President, Hugo Chavez. According to Dietrich, "the actual economic policies of [governments that have embedded Twenty-First Century Socialism into their political discourse] stuck essentially to nationalistic Keynesian strategies of development and import substitution within their existing market economies" (Dietrich, 2009, p. 171). It is in this context, in which the Ecuadorian President, Rafael Correa, took office in early 2007, with a leftist and anti-imperialist discourse. 


\subsection{Current Political Framework in Ecuador}

The current political framework in Ecuador developed in the aforementioned socio-political environment, which created the perfect broth for the emergence of a left-wing political leadership, with a discourse that was antagonistic to the sorely eroded neo-liberal approach. The following lines will briefly explore the creation of the Political Constitution in 2008, in order to understand the emergence of the term Sumak Kawsay. The remainder of this section will look at the government's use of Sumak Kawsay in the political discourse.

\subsubsection{Political Constitution of 2008 - The Emergence of the Sumak Kawsay}

The current Ecuadorian President, Rafael Correa, started his political career in 2005 as Minister of Economy and Finance. Soon after his appointment, Correa showed his dissatisfaction with the Neoliberal approach that had reigned in the Latin American region, and called for an alternative economic viewpoint. In 2006, he was elected President, through the political party Alianza País, ${ }^{23}$ under the slogan The Citizens' Revolution. The formulation of a new Constitution was Correa's main electoral platform, which he claimed would allow for more sensitive and inclusive public policies (CIDOB, 2013; Diario El Universo, 2006). This aspect generated enthusiasm in the society due to the historic political instability of the country. In fact, in 180 years of the Republic's history, Ecuador has had 19 Constitutions, which have lasted between 1 and 25 years (Paz y Miño \& Pazmiño, 2008). Most of the governance frameworks created by previous Constitutions contributed to the perpetuation of privileges for the groups already in power, as well as the segregation of indigenous groups and other minorities. The wide participation that followed the process of creation of a new Constitution allowed for the introduction of various innovative concepts, such as the Rights of Nature ${ }^{24}$ the principles of Sumak Kawsay; and, the importance of food sovereignty. The following section will address the conceptualisation and political use of Sumak Kawsay.

\footnotetext{
${ }^{23}$ Alianza País can be translated to English as "Partnership for the Country". This is not a literal translation (author's translation).

${ }^{24}$ The Rights of Nature are recognised in Articles 71 to 74 in the Political Constitution. Article 71 establishes that "Mother Nature or Pachamama [is where] life is produced and reproduced, [and therefore ...] has the right to be fully respected [...] [I]ts vital cycles, structure, function and evolutionary processes need to be maintained and restored" ("Political Constitution," 2008, Art. 71-74, author's translation).
} 


\subsubsection{Sumak Kawsay as a Concept and Discourse}

The Kichwa concept of Sumak Kawsay had been widely used by indigenous social movements before it was embedded in the current Constitution. The Confederation of Indigenous Nationalities of Ecuador (CONAIE) presented the concept of Sumak Kawsay to the Constitutional Assembly in 2007, framed in a plurinational and inclusive proposal (Cortez, 2009). After the approval of the Constitution through referendum, the government has used the term Sumak Kawsay extensively, translating it to Buen Vivir, in Spanish, and Good Living in English. The Ecuadorian government has claimed the term as the aim that the current governance framework is directed to, and consequently, the National Planning Secretariat (SENPLADES) has prepared the National Plan of Good Living. ${ }^{25}$

It has been suggested that beyond its real meaning, the term Sumak Kawsay could be used as a political umbrella that includes any policy of the current government (Escobar, 2010). In this regard, Escobar (2010) highlights that the discourses of the Ecuadorian and Bolivian Presidents have been highly contradictory to the principle of harmony with nature inherent in Sumak Kawsay and Suma Qamaña, respectively. In the case of Ecuador, the latest mining policies, as well as the "contemplation of the expansion of the oil frontier [...], five mega mining projects [...], the vertical integration of peasant families to agribusiness companies $[\ldots]$ and the expansion of agrofuel plantations", show a gap between the discourse and actual priorities of the government (Accion Ecologica, n.d., para. 23, author's translation). Along the same lines, Luis Macas, Ecuadorian politician and indigenous leader, states that translating Sumak Kawsay as Good Living is a mistake as it limits the deep and ancestral meaning of the concept, which, according to him, could be better translated as Life in Fullness, which is "the result of the interaction of the human and natural existence, $[\ldots$ it $]$ is the state of fullness of all the vital community" (Macas, 2011, para. 9, author's translation). He further argues that Good Living is known in Kichwa as Alli Kawsay, which in turn refers solely to the Good in Life. In contrast, Sumak Kawsay involves a harmonic communitarian living and a relationship with nature, which is well beyond the western perception of well-being (Ibid).

\footnotetext{
${ }^{25}$ SENPLADES has elucidated that Good Living is a call for social justice, "through the recognition, evaluation and dialogue between peoples and cultures, ways of knowledge and life" (SENPLADES, n.d., author's translation)
} 
On the other hand, some academics question the legitimacy of the use of Sumak Kawsay, even by indigenous politicians, as there is no anthropological evidence, they claim, of the grassroots origin of the term (RP-AC-1, 2012). In relation to this, Mrs. María, one of the interviewees, and indigenous woman of the Province of Chimborazo, explained that she had never heard the term Sumak Kawsay: "I have just heard of Alli Kawsay, which means 'to live a happy life"' (2012). Evidently, Sumak Kawsay has resulted in understandings and usages that vary greatly from the elites to the grassroots, and among different groups of interest. However, beyond its origins and legitimate meaning, it is argued that the extended usage of the term and its inclusion in the legal framework allows for the amalgamation of concepts that were formerly divorced, as it is the case of nature and culture (Escobar, 2010). Accordingly, onthological struggles emerge, challenging the dominant dualist ontologies through which westernised societies had created racial, classist, social and cultural dualisms; separating the elites in power from the oppressed, the colonisers from the colonised, and the human from the non-human (Ibid).

The Sumak Kawsay has been embedded in the mid-term government plan, which has influenced the governance dynamics within the country. Therefore, the next section will address the institutional structure for rural governance.

\subsection{The Institutional Framework for Rural Governance in Ecuador}

The approval of the new Political Constitution encouraged greater financial and administrative autonomy to subnational governments. ${ }^{26}$ Accordingly, the Organic Code of Territorial Organisation, Autonomy and Decentralisation (COOTAD) was approved, with the aim of allowing a better coordination between the national and sub-national levels. Figure 5.1 presents a scheme of the national and sub-national dynamics, after the approval of the COOTAD. It is noteworthy that prior to the law, the coordination structures between the different levels of government were not clearly established, which resulted in dramatic welfare differences between urban and rural areas (Guerrero, 2008). Provincial governments were essentially called to do road work in the areas not covered by the municipality and had a

\footnotetext{
${ }^{26}$ Subnational governments in Ecuador are: provincial governments, local governments and parishes, in order of its geographical span and size.
} 
very high reliance on funding from the central government. Additionally, there was no support for self-management in rural areas (Ibid).

\section{Figure 5.1: National and Sub-National Dynamics - Vertical Coordination}

\section{National Executive Power}

- Horizontal Coordination (Ministries and Secretariats)

\section{Sub-National Executive Power}

\begin{tabular}{|c|l|}
\hline $\begin{array}{c}\text { Decentralized } \\
\text { Autonomous Regional } \\
\text { Government }\end{array}$ & $\begin{array}{l}\text { - Regional Council } \\
\text { - Regional Governor }\end{array}$ \\
\hline $\begin{array}{c}\text { Autonomous Provincial } \\
\text { Government }\end{array}$ & $\begin{array}{l}\text { - Provincial Council } \\
\text { - Prefect }\end{array}$ \\
\hline $\begin{array}{c}\text { Autonomous Municipal } \\
\text { Government }\end{array}$ & $\begin{array}{l}\text { - Municipal Council } \\
\text { - Mayor }\end{array}$ \\
\hline $\begin{array}{c}\text { Autonomous } \\
\text { Decentralized Rural } \\
\text { Parish }\end{array}$ & $\begin{array}{l}\text { - Rural Parish Board } \\
\text { - Chairman of the Parish Board }\end{array}$ \\
\hline
\end{tabular}

Elaboration: Author

Source: “COOTAD,” 2010

The COOTAD established clearer roles with the provision of resources for sub-national governments, particularly rural parishes, which were significantly empowered with additional resources and responsibilities. ${ }^{27}$ Likewise, the COOTAD determined coordination mechanisms between the development plans of all the levels of government: rural parish plans need to be aligned to the corresponding municipal government plan; municipal government plans need to be aligned to the correspondent provincial government plan; and provincial government plans need to be aligned to the National Plan of Good Living ("COOTAD," 2010). However, the latter has suddenly created new responsibilities that some rural parishes have not been able to fulfil due to their low institutional capacity (RP-PG-1, 2012). The fact

\footnotetext{
${ }^{27}$ It is worthwhile mentioning that the Ecuadorian Constitution of 1998 already recognised the Rural Parishes as a form of sub-national government. Nevertheless their role and responsibilities, planning capacity and financial resources have been strengthened through the Political constitution of 2008, and the consequent approval of the COOTAD.
} 
that there are 1,500 rural parishes in 221 municipalities and 23 provincial governments in a country with an area of $283,560 \mathrm{~km}^{2}$ and 14,483,499 million people (INEC, 2010), indicates a complex political structure. ${ }^{28}$ In order to clarify the sectoral coordination, also known as the horizontal coordination within the national government, Figure 5.2 presents the institutional apparatus of ministries and secretariats.

${ }^{28}$ The Province of Galapagos is under a Special Regime Governing Council due to its importance to the conservation of its natural world's heritage ("COOTAD," 2010, Art. 28). 


\section{Figure 5.2: The Executive Power at the National Level - Horizontal Coordination}

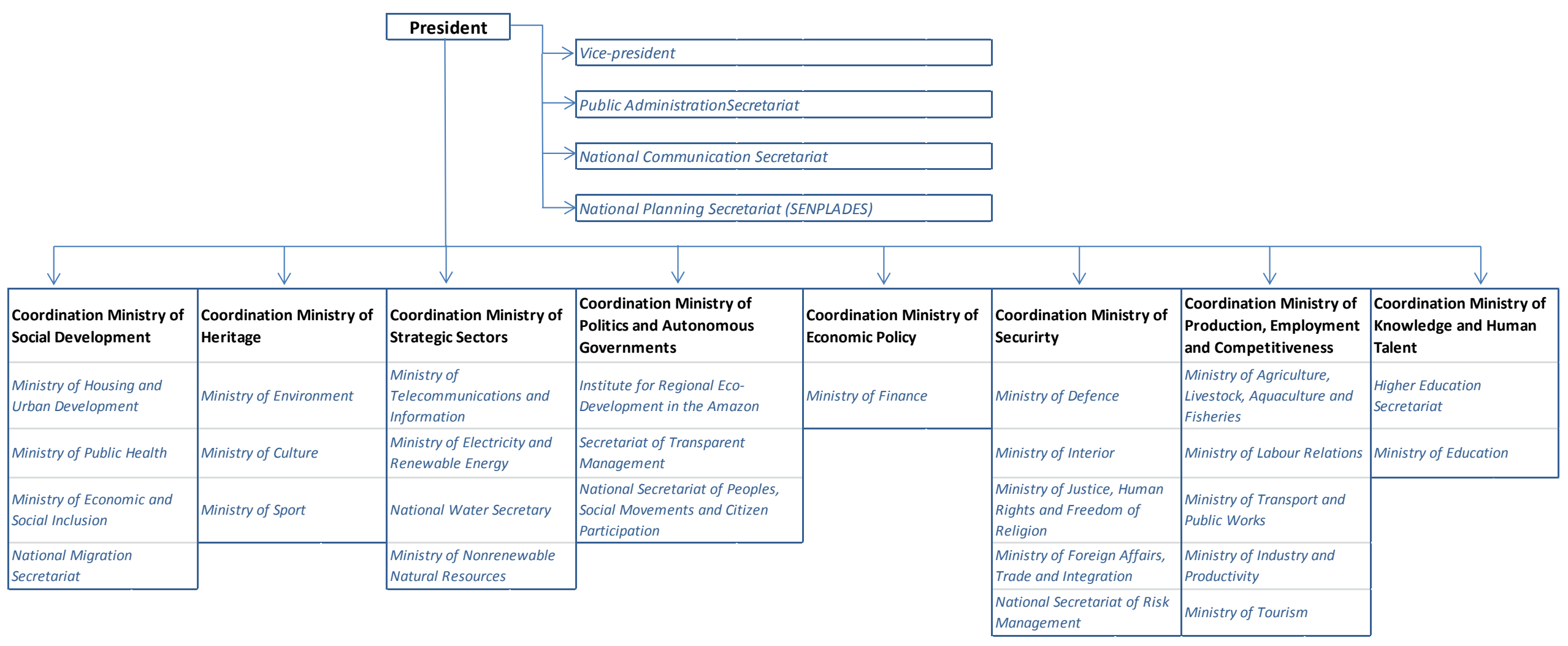

Elaborated: Author

Source: Adapted from Gabinete de la Revolución Ciudadana (n.d.) 
The governance framework for food sovereignty will be thoroughly addressed in Section 5.4 of this chapter. Notwithstanding, as displayed in Figure 5.2, the Ministries of Economic and Social Inclusion; Environment; Agriculture, Livestock, Aquaculture and Fisheries; as well as the national Water Secretariat, all belong to different Coordination Ministries, which could suggest a complex governance framework at the national level.

\subsubsection{Legislation and Plans Related to Food Sovereignty}

The following paragraphs will present an analysis of the legal framework relevant to food sovereignty, featuring the most important facts of each legal body, and the implications for the implementation and practice of food sovereignty.

\section{Political Constitution}

It establishes the character of the society and its government, and the principles that regulates the political, legal and social aspects of the country. It was approved in 2008, after a highly participatory process that allowed for the introduction of innovative topics like food sovereignty and the Rights of Nature. In relation to food sovereignty, it determines the responsibility of the State for its promotion, and recognises the importance of biodiversity and natural and genetic heritage. It also established the need for the creation of the Law of Food Sovereignty.

\section{Organic Law of Food Sovereignty (LORSA)}

The final version was approved in 2009 and its latest amendment was passed in 2010. It establishes the importance of food sovereignty, and outlines the components, which need to be taken into account for its achievement. It determines the creation of eight complementary laws which address the following areas: a) land and water management; b) agro-biodiversity and seeds; c) community management; d) commercialisation of farming produce; e) access to credit; f) food safety and animal health; g) agro-industry; and, h) fisheries. Unfortunately, until February 2013 only the bills that address the three first topics have been submitted to the 
National Assembly, and none of them have passed to the second debate. Without the approval of the eight complementary laws, the LORSA is unenforceable.

\section{Law of Production, Trade and Investments}

It was approved in 2010. It seeks to regulate the production and exchange of goods and services, and fosters the improvement of productivity. It also determines a new tax on the rural property, which could affect small-scale farmers. There is a small section on ecoefficiency and sustainability through an economic incentive for clean production. In general, this law does not seem to represent the interests of farmers and needs in rural areas. It does not mention the need for local markets for farmers, and does not consider the need to build management skills in rural areas.

\section{Law for Tax Equity}

It was reformed in 2007, but became effective in 2010. It determines changes in the tax system, with regard to the possession of rural land of less than 25 hectares (ha). This tax negatively affects most small-scale farmers and communities. It foresees a mechanism for the exoneration of taxes, but this requires farmers to undertake an additional procedure to not have this tax applied. This might not be easily fulfilled as they live in remote areas, far away from the cities.

\section{National Plan of Good Living}

It is the mid-term government plan for the period between 2009 and 2013. It determines 12 development objectives, its strategies and plans of action. Nevertheless, it is highly focused on the competitiveness of agroindustry. The consideration of all the components and a holistic meaning of food sovereignty are not evident. 
Agenda for Rural Good Living

It recognises the importance of peasant farming. Its content is positive in that it prioritises the provision of basic services in rural areas. However, in practice it does not seem to have a clear link with the National Plan for Good Living. In addition, there is no clear information about the state of progress of the agenda, or the actions taken by the corresponding Intersectoral Committee.

Information System for Food Security, Food Sovereignty and Nutrition (SISSAN)

It was created through the LORSA and is part of a wider social indicators system. The terms of food security and food sovereignty are often used interchangeably in some documents, in spite of the great differences in the meaning and connotation of both terms. The information presented is very limited at the moment, and uses conventional statistics that do not represent the needs of the communities in relation to food sovereignty.

After having explored the legal framework relevant to food sovereignty, the next section will assess the policies and strategies implemented by the Ecuadorian government according to five aspects that are particularly important for food sovereignty. 


\subsection{Assessment of the Legal and Institutional Framework in Ecuador with Reference to Food Sovereignty}

Food Sovereignty is a strategic objective and an obligation of the State in order to ensure that individuals, communities, peoples and nationalities achieve food self-sufficiency and have permanent access to culturally-appropriate food ("Political Constitution," 2008, Art. 281, para. 1 , author's translation). ${ }^{29}$

The topic of food sovereignty has been given a chapter in the current Ecuadorian Constitution. In the two articles that relate to food sovereignty (Articles 281 and 282), there are 14 responsibilities of the State, which cover areas such as: boosting small-scale production; promoting the use of agroecological technologies; implementing redistributive and inclusive policies; protecting and recovering the agro-biodiversity; and, promoting the association of small producers, among others. It is also stated that the concentration of landownership is prohibited, and that the State will facilitate the processes for the distribution of productive resources. Nevertheless, in spite of the legal framework that supports the development of food sovereignty, there are several aspects that need a deeper analysis: a) promotion of green technologies; b) bio fuels; c) genetically modified (GM) crops; d) access to productive resources; and, e) the Agrarian Revolution Schools (ERAs).

\subsubsection{The Promotion of Clean Technologies}

Article 15 of the Political Constitution establishes that "it is the State's responsibility to promote the use of clean technologies", and that "internationally banned agro chemicals cannot be produced and distributed in the country" ("Political Constitution," 2008, Art. 15, para. 1-2, author's translation). The latter is of the utmost importance for small-scale farming. Unfortunately, there is evidence that some of the policies and programmes in the rural sector are opposite to these fundamental principles. Firstly, the delivery of highly subsidized urea has become one of the flagship programmes of the Ministry of Agriculture. Hundreds of thousands of tons of urea, in the form of $50 \mathrm{~kg}$ sacks, have been delivered by the government to farmers, from 2007 to the time of writing, with the intention of improving their

\footnotetext{
${ }^{29}$ In this context, nationalities refer to "indigenous nationalities". There are 14 indigenous nationalities in Ecuador. A nationality is an indigenous community that speaks the same language. There are several peoples within a nationality that distinguish from each other through their specific customs.
} 
productivity (MAGAP Ecuador, 2012). However, the delivery of urea is incompatible with the principles of agroecological farming:

If you take an earthworm and put [a grain] of urea, it dies immediately. So if you put urea to the soil, you are killing earthworms [and other microorganisms], which provide the soil with oxygen and protein. When the soil dies, you need to put more and more urea. Consequently the [input] costs are not [economically] viable any more (RP-FEN-1, 2012, author's translation).

In spite of the negative effects of urea, in January 2013 the current government launched a project for the construction of an industrial plant for urea in order to substitute imports from Venezuela (Diario El Comercio, 2012; MAGAP Ecuador, 2013). The agricultural sector in Ecuador demands around 500,000 tons of urea every year, and the government is providing farmers with this input at a price two or three times cheaper than the market price (MAGAP Ecuador, 2012). According to the spokesman of the Ecuadorian Pre-Investment Institute, the government is considering two options for the planning and construction of the urea processing plant: the utilisations of biomass waste, or the use of petroleum residues (Diario El Hoy, 2013). Article 313 of the Constitution affirms that "the biodiversity and genetic heritage" are considered "strategic sectors" ("Political Constitution," 2008, Art. 313, para. 3, author's translation). However, the soil seems to not be seen as part of Ecuador's natural heritage.

Secondly, even though the Constitution was approved in 2008, until August 2012 red label agro-chemicals were still freely commercialised in the country. Technical staff from the Ministry of Agriculture asserted that the Ecuadorian Agency for Agro Quality Assurance (AGROCALIDAD) is responsible for the regulation of the production and distribution of agricultural inputs. They alleged that the trade of these highly toxic chemicals are affordable for small farmers, and that green label agro-chemicals would cost significantly more (RPMA-1, 2012). The lack of leadership at the Ministry in regard to this topic shows a dissonance between some government policies and basic principles of food sovereignty and agroecology. 


\subsubsection{Biofuels}

Article 15 of the Political Constitution establishes that energy sovereignty will not be achieved at the expense of food sovereignty. This aspect is crucial if we consider the enlargement of the agricultural frontier over the last 50 years (See Chapter 4). In fact, first generation agro fuels require processing edible crops, resulting in high social and environmental impacts (Castro, 2011). The government has openly stated its interest in the production of agro fuels and the diversification of the energy matrix, which is currently highly dependent on oil. Notwithstanding, if the option supported by the government results in the usage of palm or sugarcane, rivers, streams and portions of the tropical rainforest could be affected (Ibid, p. 95). Moreover, the energy policy would require the coordination of at least the Ministries of Environment, Agriculture, Electricity and Renewable Resources, and Industry and Productivity. As shown in Figure 5.2, most of them are associated with different Coordination Ministries. This could suggest a gap in the horizontal coordination at the national level. While this assertion could be presumptuous, at least the natural and obvious coordination channels are not clearly denoted in the governance scheme (refer to Figure 5.2).

It is, however, important to mention that the government's effort in transforming the current energy matrix and consideration of avant-garde technologies is a meritorious step. There is evidence that the government is considering the production of second and third generation biofuels, which have positive environmental and social impacts (CEDA, 2012; de Alonzo, 2012).

\subsubsection{Genetically Modified Crops}

Genetically Modified (GM) crops are known to be detrimental to the environment, as GM seeds need to be cultivated as a monoculture with a very high utilisation of agro toxics to control pests (J. E. García, 2007; Gonzalez, 2012; Lu et al., 2010). The latter puts the farmers' and consumers' health at risk due to the potential of contamination of the fruit (Vicente et al., 2004). Additionally, as pointed out in Chapter 3, there is no clarity about the effects of the combination of genes of different species on the health of humans (Meehan, 2010). The Ecuadorian Constitution has an ambiguous position around this topic: Article 401 declares "Ecuador free from GM crops and seeds" but subsequently states that "only when there were 
reasons of national interest, properly informed by the President of the Republic and approved by the National Assembly, genetically modified seeds and crops can be introduced in the country" ("Political Constitution," 2008, Art. 401, author's translation).

The lack of definition of this aspect has been criticised by various NGOs, social activists, academics and farmers, due to the fact that the political discourse and the economic needs can modify the government's priorities, leaving the topic of GM crops as an unresolved issue that ultimately depends on political will (RP-AC-1, 2012; RP-NGO-2, 2012; RP-PG-2, 2012). One of the eight complementary laws to the LORSA, which addresses seeds and limits the introduction of GM crops, has not yet been approved, in spite of it having been submitted to the National Assembly in March 2012. A second major objective of this bill is to support and encourage the use and conservation of native seeds. In this respect, the National Autonomous Institute for Agricultural Research (INIAP), which is ascribed to the Ministry of Agriculture, has openly shown its opposition to the bill. Farmers and agroecologists maintain that native seeds have undergone a millennial process of continual improvement, regarding both yield and pest resistance. The latter happens through the domestication of seeds. Along these lines, the president of National Federation of Peasant, Indigenous and Black Organisations (FENOCIN) states that:

Research centres believe that peasant seeds are static, and that is not true. Peasant seeds have an ongoing and autonomous process of improvement, which is specific to each community (Andrango, 2012, author's translation).

In contrast, INIAP specialises in the development of hybrid seeds in a laboratory, with the aim of finding varieties that can be productive while resistant to plagues. One of the technical staff of the Ministry of Agriculture explained the seed development process as:

[...] a process of hybridisation, genetic breeding. The crossing of two specimens of the same species, in order to have better characteristics than their parents. For example, a high-yield variety that is susceptible to a certain disease is crossed with a variety that is resistant to that disease. One of the 'children' turns out to be productive as the 'mother' and resistant as the 'father (RP-MA-2, 2012, author's translation).

However, hybrid seeds are infertile after the first harvest. After the plantation of hybrid seeds, farmers have to buy seeds for each subsequent harvest, increasing their input costs and 
making them totally dependent on those seeds. A process that is alien to nature, and like hybridisation, requires the continual use of pesticides and fertilisers. In fact, hybrid seeds cannot be cultivated in association with other crops (RP-PG-2, 2012). According to the 2011 Annual Report of the Programme of Agricultural Innovation, the Ministry of Agriculture has delivered great amounts of certified seeds to farmers: $9,000 \mathrm{~kg}$ of wheat seeds, $73,879 \mathrm{~kg}$ of rice seeds, 196,000 seedlings of banana, 49,000 of corn seeds, and 525,389 potato seeds (MAGAP, 2012, p. 10). Additionally, the processes in which INIAP staff select the best seeds have not always been culturally sensitive. One of the interviewees, who asked to remain anonymous, commented:

In one of the territories where we were working, we saw that the INIAP invented a contest for selecting the best [...] seeds. Staff from INIAP took genetic material of the best plants throughout the whole country, in order to breed them [...]. They did not explain to farmers and communities what they were planning to do with the plants. They are more focused on commercial agriculture, but not so much on food (RP-NGO-3, 2012, author's translation).

This evidence shows that authorities and policy makers still need to comprehend the importance of defending locally domesticated seeds for the achievement of food sovereignty.

\subsubsection{Policies on Availability of Productive Resources}

This section of the chapter seeks to analyse the extent to which farming communities have access to productive resources, and the public policies that have been implemented in order to address this issue. Such analysis will be centred on three main areas: Land, Water and Credit.

\section{Land Access}

Access to land is a significant issue that generates greater socio-environmental conflicts. Lack of land distribution would turn the achievement of food sovereignty into a chimera (RP-NGO4, 2012). Article 282 of the Constitution establishes the creation of a Land Fund for the distribution of land among farmers. According to the government, from 2010 to the end of 2012, around 20,000 ha had been distributed to farmer families (Diario El Telegrafo, 2012). Likewise, around 4,000 ha of ancestral lands have been legalised under the management of indigenous communities, especially in the Amazonian rainforest (Ibid). However, the current 
structures of private land tenure have not being challenged. Ospina and Mena suggest that the declarations of the government between 2009 and 2011 forecasted a decrease in the GINI index of land tenure of around 20 points (in Carrión \& Herrera, 2012). According to these scholars, one and a half years after these declarations, only $0.30 \%$ of the land owned by the State had been distributed (Ibid). Accordingly, while there is some progress regarding the distribution of land owned by the government, the private land tenure structures still need to be challenged (see Chapter 4).

\section{Water Access}

The Political Constitution positions water as a fundamental right and a strategic asset of the country ("Political Constitution," 2008, Art. 12). Furthermore, in Articles 15, 32, 66 and 264 water management is associated with access to food, health and a sound environment. Article 281 of the Constitution states that redistributive policies need to be implemented in order to guarantee water access to farmers (León, 2008). Nevertheless, Mrs María, one of the interviewees from the Province of Chimborazo, explained that her community went to the capital city to address their lack of access to water (2012). A large property nearby, owned by a private family, had requested the concession of irrigation water. Unfortunately they did so ahead of the community. The community leaders were not properly informed about the regulations, even though they had been using that stream for several years. Yet, because access to that stream had been legally granted to the owners of the large property, the whole community (of more than 100 families) was struggling to access water for their production. According to Mrs María, the community had varied production practices, and while some had enough surplus for the market, most of the families were mainly dedicated to subsistence agriculture (2012). Moreover, a high percentage of the land owned by the community was cultivated solely by women, who also had to fulfil their roles as mothers and wives, placing a great responsibility on them for both the household and the farm (Mrs María, 2012). This case evidences that the government needs to take additional measures in order to grant equal access to water and other productive resources to communities. 


\section{Financial and Economic Access}

The government has opted for the establishment of the Popular and Solidarity Economy. The Good Living concept implies a re-definition of the economy that would position humans and the environment in the centre (León, 2008). In order to offer the agricultural sector greater access to credit, the current government has provided the National Development Bank with substantial resources designated for this sector of the economy (Carrión \& Herrera, 2012). Notwithstanding, doubts exist about whether the credits are being delivered to small-scale agriculture (Ibid). Lack of access to credit was one of the main concerns of the interviewees. One of them claimed that:

Today, no one gives me credit for planting sweet potatoes. There is [credit] only for monocultures of [common] potatoes. There is no funding for cabbage, beans, etc. (RP-FEN-1, 2012 author's translation).

Furthermore, the problem with access to credit is that it is not suitable for farming systems, as the credits are adapted to the commercial payment periods and not to the production cycles (Andrango, 2012). This aspect was confirmed by one of my interviewees, who is a farmer and community leader. He mentioned that, when his fellow farmers asked for funding, the creditors would not care if the harvest was good or if they lost all the production; the payment deadlines were inflexible (RP-FEN-1, 2012). In contrast, his experience as a board member of a community bank was significantly different:

We started with four credit branches: we gave them credits for pigs, chickens, corn and rice. When they lost their crops, we would renew the credit, with the same interest rate, but we would also advise them that they should plant a bit more so that they could pay both credits. We would always start with a very small credit [...] We would tailor a payment plan. We have always recovered the credits, but sometimes with longer payment times (RP-FEN-1, 2012, author's translation).

There is evidence that the current government is making changes regarding the conceptualisation of economy with a wider meaning: for example, the Law for Popular and Solidarity Economy introduces the concept of Care Economy in which people who devote themselves to activities of reproduction and life support are considered part of the economic system. This recognition has allowed housewives to have access to the social health system for the first time in their lives. Notwithstanding these innovations, more grassroots-based research regarding popular economy needs to be done, as there seems to be a lack of 
understanding about the economic role and importance of the peasant economy. Carrion and Herrera (2012) suggest that, while there has been an important increase in the allocation of resources for agriculture, these resources have nurtured mainly agro-industry and exportagriculture. The resources for peasant agriculture have been designated to social assistance programmes, denoting that the government does not regard peasant agriculture as a productive activity (Ibid).

\subsubsection{Agrarian Revolution Schools (ERAs)}

The agrarian Revolution Schools are one of the flagship programmes of the current government in the rural areas of Ecuador. Its planning process started in 2010 and its implementation began year 2011 (MAGAP, 2012). By May 2012, the ERAs project had 337 facilitators with training in agronomy, agro-industry and veterinary science (RP-MA-2, 2012). The project had around 1,400 ERAs and involved more than 34,000 farmers throughout the country. According to the Ministry of Agriculture, the objective of the ERAs is to "contribute to food sovereignty based on the increased productivity of major crops through knowledge dialogue between [facilitators] and small and medium farmers [...]" (MAGAP, 2012, p. 9 author's translation). Staff from the Ministry of Agriculture described the project as "highly participatory and focused on the needs of farmers" (RP-MA-2, 2012, author's translation). They further suggested that the programme's aim is to learn by doing, through the use of an experimental plot, in which first-hand experimentation takes place (Ibid). Part of my field research consisted of several interviews with staff from the Ministry of Agriculture, as well as field visits to three ERAs in the southern part of the Sierra region. Out of that experience, a reflection regarding the possible widespread practice inherent to extractivist agriculture is offered.

\section{Extractivist Approach}

Social organisations are concerned about the possibility of perpetuating the extractivist approach to agriculture through the widespread use of the ERAs (RP-CFS-1, 2012; RP-FA-2, 2012; RP-PG-2, 2012). In fact, the methodology of the ERAs establishes the selection of one or two crops per year, and accordingly the course curriculum is adapted to those particular crops. This contradicts the integral vision of food sovereignty, in which the concept of 
biodiversity is evident (see Chapter 7). Additionally, in several interviews it was noted that the support offered by the ERAs depends on the vocation of the land.

This means that if farmers (many colonised by the agroindustrial approach) had been producing monocultures and thus giving preference to cash crops, the facilitators do not challenge this approach, and instead offer conventional ways for making the extractivist agriculture more productive. In the 2011 Annual Report, it could be noted that the majority of

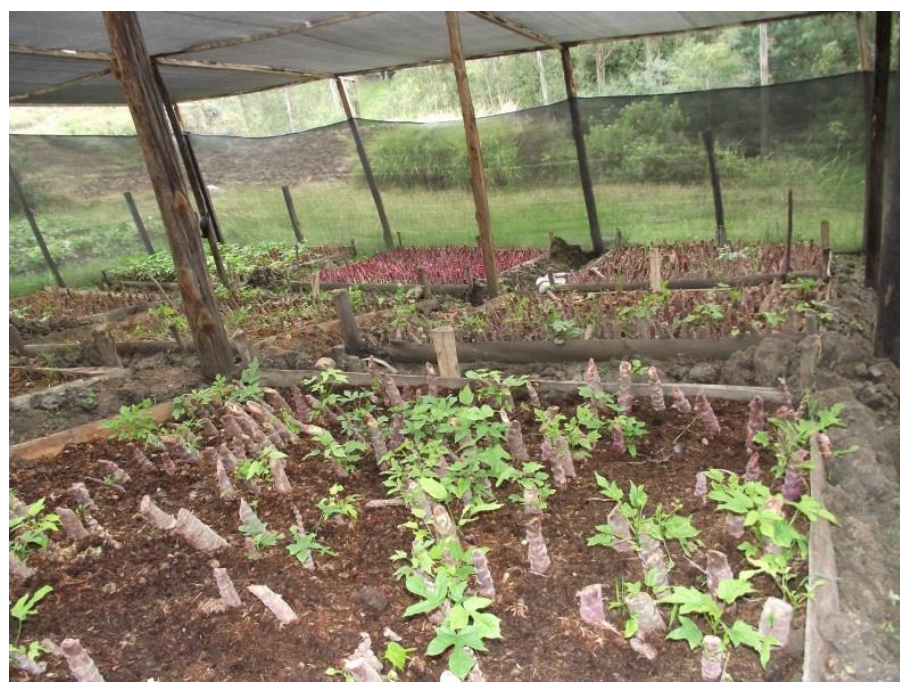

Plate 5.1: Babaco greenhouse nursery for monoculture plantation - Field visit ERA, Province of Loja, June, 2012 schools were working with a mixed approach: while facilitators would teach farmers to make bio-fertilisers, they would also utilise chemicals, and would not consider the wholeness of the sowing field and the local seed varieties. In one of the visits to the ERAs, I could see how one crop - babaco - was planted as a monocrop (Plate 5.1). Moreover, some of the facilitators of the ERAs mentioned how peasant families, who were producing tomato and other vegetables as cash products, would not include vegetables in their daily diet, because of the high level of chemicals that those products had been treated with. They would either have a separated land slot for the cultivation of their vegetables, or would eat solely cuy and carbohydrates (RPMA-3, 2012). ${ }^{30}$

In spite of these remarks, there was evidence that facilitators were sensitised in relation to the use of chemicals, due to their own previous experiences. I could see that schools were certainly participatory, and that facilitators helped communities not only with agricultural issues, but with requirements for the formalisation of their organisations. They even exerted

\footnotetext{
${ }^{30}$ Cuy means guinea pig. It is a traditional Andean dish.
} 
an advocacy role with local governments and authorities. While most of the facilitators had been trained with the conventional extractivist approach to agriculture, they seemed to be immersed in a learning process, in which some of their previous conceptions had been challenged. In contrast, I also interviewed several leaders who said that the ERAs facilitators had a very strong position towards the use of agro-chemicals, and therefore the organisation had to stand firm and not accept the intervention of the Ministry staff.

In conclusion, the ERAs programme as a governance tool has positive aspects, especially if considering the proximity of the technical assistance to farmers and their reality. However, the proposal of the ERAs methodology is to work with between 25-30 farmers per school, and there is one school per community, but farming communities normally encompass more than 30 members. This could break the existent social structures in the community. In consequence, I suggest that the ERAs methodology should consider the organic structures of communities, as well as their relationship with nature and their ancestral knowledge.

\subsection{Summary}

This chapter has contributed to the understanding of the legal and institutional dynamics that frame the governance and practice of food sovereignty in Ecuador. The first two sections of the chapter presented a historic compendium of the most relevant events that led to the turn to the left in Latin America and illustrated the current socio-political environment in Ecuador, as well as the government's approach to Sumak Kawsay. After exploring the institutional framework for the rural areas, section four of this chapter assessed the governance approach inherent to food sovereignty in five aspects that are of particular importance. It is evident that the delivery of urea; the lack of a ban on highly toxic chemicals; the ambiguity in relation to the introduction of GM crops; and the potential of promoting the extractivist approach to agriculture through the ERAs, are aspects that work against the achievement of food sovereignty, and which the government should pay special attention to. This chapter has set the institutional context of food sovereignty, so as to allow for the deepening into the Ecuadorian case through two case studies. Chapter 6 will present a case study on the institutionalisation of food sovereignty in a national social movement of peasants and ethnic 
groups, in spite of the obstacles outlined in Chapter 4, and the legal-institutional barriers presented in this chapter. 


\section{Chapter 6}

\section{Case Study FENOCIN}

This chapter will present a case study on the National Federation of Peasant, Indigenous and Black Organisations (FENOCIN). The analysis will focus on how the association of several social organisations facilitated the institutionalisation of food sovereignty and agroecology at local and regional levels. This chapter is divided into three main parts. In the first part, I will focus on the characterisation of FENOCIN and the milestones towards its consolidation. The second part of the chapter will analyse the federation's structures of representation, and the final section will present the federation's understanding of food sovereignty and agroecology, and how those understandings have been implemented in the field. The information and analysis presented in this chapter will address the third research objective.

\subsection{History of the Consolidation of Indigenous and Peasant Organisations in Ecuador}

As referred to in previous chapters, indigenous groups and mestizo peasants have suffered the worst consequences of the Spanish colonisation and of the development approach adopted in the region. As a result, these groups have reacted and taken various initiatives, motivated by the struggle for land and resources in the rural areas. Embryonic organisational efforts took place between 1919 and 1934. Table 6.1 displays the milestones that contributed to the consolidation of indigenous and peasant movements in Ecuador. One of the most important events in the development of the indigenous movements was the passing of the Law of Communes in 1937, due to the opposite reactions that it generated. On one hand, academic mestizos regarded it as a positive step towards the formal recognition of the organic indigenous organisation (Sánchez Parga, 2007). On the other hand, indigenous leaders felt that the spirit of the traditional organisational structure of indigenous communities was not represented in the law, which motivated the formation of a front to resist it (CONAIE, 2010). 


\section{Table 6.1: Historic Milestones in the Consolidation of Indigenous and Peasant Movements in Ecuador}

\begin{tabular}{|c|c|}
\hline Year & Milestone \\
\hline 1919 & $\begin{array}{l}\text { The shift in the relationship between peasants and landowners starts with an indigenous } \\
\text { uprising (CONAIE, 2010). }\end{array}$ \\
\hline 1920 & $\begin{array}{l}\text { Indigenous communities start to organise and build synergies in the Sierra region of } \\
\text { Ecuador, in order to "put an end to the extreme abuses which the indigenous peoples } \\
\text { [were] subject to, in the large-scale farming" (CONAIE, 2010). }\end{array}$ \\
\hline 1934 & $\begin{array}{l}\text { A meeting of indigenous leaders takes place, in order to build regional ways of } \\
\text { organisation. }\end{array}$ \\
\hline 1937 & $\begin{array}{l}\text { The Law of Communes is passed. Academics, such as José Sánchez Parga (2007), regard } \\
\text { the passing of the law as a "slow but steady process of indigenous organisation", which } \\
\text { would correspond to the beginnings of the actual, consolidated indigenous movement in } \\
\text { Ecuador (Ibid, p. 23). However, indigenous movements see the law as "unfortunate" and } \\
\text { as an obstacle to the traditional organisational structure of indigenous people (CONAIE, } \\
2010) \text {. }\end{array}$ \\
\hline 1938 & $\begin{array}{l}\text { The Ecuadorian Confederation of Catholic Workers (CEDOC) is founded, with a strong } \\
\text { Catholic focus and with a right-wing inclination. The main purpose of the organisation } \\
\text { was to consolidate the workers union with an ecclesiastical and religious approach } \\
\text { (FENOCIN, 1999). }\end{array}$ \\
\hline 1944 & $\begin{array}{l}\text { The Ecuadorian Federation of Indians, (FEI) is established, with support of the } \\
\text { Communist Party and the Ecuadorian Confederation of Workers (CTE). }\end{array}$ \\
\hline 1964 & The Law for Agrarian Reform and Colonisation is issued. \\
\hline 1965 & $\begin{array}{l}\text { CEDOC goes from a religious to a workers' union rationale. Accordingly, it promotes the } \\
\text { creation of the Ecuadorian Federation of Agricultural Workers (FETAP). This } \\
\text { organisation was mainly concerned with the abolition of the Huasipungos, }{ }^{31} \text { and had a } \\
\text { strong focus on improving the situation of waged rural workers (FENOCIN, 1999). }\end{array}$ \\
\hline
\end{tabular}

\footnotetext{
${ }^{31}$ The Huasipungo system was established after the Spanish colonisation. Huasipungo was a piece of land that mestizos or Spanish, in the position of masters gave to indigenous people for their agricultural and pastoral work. It was the institutionalisation of oppression over indigenous ethnic groups from the Sierra, as the indigenous workers were considered part of the land property, and the land given to them for landwork was sterile and marginal. The Huasipungo system started to be challenged in Ecuador in the 1940's and 1950's (Korovkin, 2008) and was abolished with the Law for Agrarian Reform and Colonisation, in 1964. Nevertheless, a semifeudal system remained for several years.
} 
Table 6.1: Historic Milestones in the Consolidation of Indigenous and Peasant Movements in Ecuador (continuation)

\begin{tabular}{|c|c|}
\hline Year & Milestone \\
\hline 1968 & $\begin{array}{l}\text { The members of FETAP transform their focus to a more critical one, and hence their } \\
\text { organisation becomes the National Federation of Peasant Organisations (FENOC). They } \\
\text { start to demand modifications to the Law for Agrarian Reform, as well as clear } \\
\text { mechanisms for its implementation (FENOCIN, 1999). }\end{array}$ \\
\hline 1972 & $\begin{array}{l}\text { An organisation created for and by the indigenous peoples of the highlands is } \\
\text { constituted. It receives the name of ECUARUNARI (ECUARUNARI, n.d.). }\end{array}$ \\
\hline 1973 & The amendment to the Law of Agrarian Reform and Colonisation is passed. \\
\hline 1973 - 1974 & FENOC grows in number and undergoes a process of consolidation (FENOCIN, 1999). \\
\hline 1975 & $\begin{array}{l}\text { The Classist Unity Front (FUC) is created through the joint venture of the CTE, } \\
\text { CEDOC, Ecuadorian Confederation of Free Unions (CEOLS) and FENOC (FENOCIN, } \\
\text { 1999). }\end{array}$ \\
\hline 1986 & $\begin{array}{l}\text { The Confederation of Indigenous Nationalities of Ecuador (CONAIE) is created as an } \\
\text { umbrella organisation that would bring together the organisational expressions of } \\
\text { indigenous communities throughout the country (CONAIE, 2010). }\end{array}$ \\
\hline $1986-1995$ & $\begin{array}{l}\text { This period is regarded by FENOC leaders as a phase of crisis and stagnation } \\
\text { (FENOCIN, 1999). However, even during this period of stagnation, the grassroots } \\
\text { associations from the Sierra region underwent an internal strengthening (FENOCIN, } \\
\text { 1999). }\end{array}$ \\
\hline 1988 & $\begin{array}{l}\text { The participation of indigenous peoples within FENOC was recognised, and so, the } \\
\text { federation's name changed to FENOC-I. The acknowledgment of the indigenous } \\
\text { participation enhanced the convening power of the federation (FENOCIN, 1999). }\end{array}$ \\
\hline 1997 & $\begin{array}{l}\text { The Afro-Ecuadorian peoples appealed to the recognition of their ethnicity as part of } \\
\text { FENOC-I. This allowed the federation to be "the unique national social institution which } \\
\text { recognises the different identities and interculturality [... contributing to] tolerance [and] } \\
\text { coexistence"(FENOCIN, 1999, p. 59, author's translation). This is represented in the } \\
\text { final change of the name of the organisation: FENOCIN for its incorporation of negros } \\
\text { (black people) as an integral part of the organisation. This is how FENOCIN constitutes } \\
\text { the largest Ecuadorian social institution that has grouped people from different cultural } \\
\text { and ethnic backgrounds (FENOCIN, 1999). }\end{array}$ \\
\hline
\end{tabular}

Elaboration: Author

Note: Blue coloured cells in Table 6.1 highlight the milestones related to the process of formation and consolidation of FENOCIN.

In order to amplify the information presented in the above table, and clarify the origin of FENOCIN, the following section will expand on that information. 


\subsection{Formation and Consolidation of FENOCIN}

While FENOCIN was formally created in 1968, under the name FENOC, its origins date back to the late 1930s when the Ecuadorian Confederation of Catholic Workers (CEDOC) was established. CEDOC was supported by the Ecuadorian Conservative Party, and was influenced by the Catholic Church (FENOCIN, 1999). The issue of the Law of Agrarian Reform in 1964, and the expansion of the progressive current of the Catholic Church worldwide, allowed for a revision in the approach of CEDOC, ultimately changing its focus to a workers' union. While the Law of Agrarian Reform had a progressive approach, particularly due to the abolition of the Huasipungos, ${ }^{32}$ it did not consider the real needs of peasants, and regarded them solely as rural workers instead of independent and autonomous farmers. CEDOC promoted the creation of the Ecuadorian Federation of Agricultural Workers (FETAP) with an objective that was limited to complying with the law. However, the landworkers' ambitions surpassed FETAP's original objectives, and consequently in 1968 transformed FETAP into the National Federation of Peasant Organisations (FENOC). This event gave the organisation an autonomous character and recognised its members' backgrounds.

The increased political pressures from the private sector and large landowners regarding the amendment to the Law of Agrarian Reform in 1973, urged the formation of a counterbalance from the grassroots, which ultimately led to the strengthening of FENOC. In 1975, FENOC and other social movements created the Classist Union Front (FUC) as a way to group the opposition against the power exerted by the private sector. The latter led to the reconsideration of the organisational structure of FENOC. Accordingly, the organisation's model, which had urban roots, became rural and relied on the local and regional community governments, already established in the territories. In fact, the organisational structure currently in force in FENOCIN has maintained this approach (FENOCIN, 1999). Finally, two meaningful milestones that contributed to the diverse and intercultural focus that the federation has today were: a) the formal recognition of the participation of indigenous peoples in 1988, and b) the inclusion of black people and other minorities into the organisation in 1997 (see Table 6.1). For instance, openness towards groups with different ethnic and cultural

\footnotetext{
${ }^{32}$ See footnote 31
} 
backgrounds turned into the strength of FENOCIN, which capitalised on "unity within diversity" (FENOCIN, 2008a, para. 7) Consequently, the organisation spread nationally, and its understanding of rural issues was nurtured by the convergence of common interests and needs from different communities (FENOCIN, 1999, 2010).

\subsubsection{Plurinationality versus Interculturality}

In terms of indigenous mobilisation and convening power, CONAIE is the most significant organisation in Ecuador, and thus its structure and development have drawn the attention of academics and analysts from around the world (Albó, 2008; Escobar, 2010; Larrea Maldonado, 2008; Petras \& Veltmeyer, 2001; Solo de Zaldívar, 2008b, among others). However, in spite of the undeniable influence that CONAIE has exerted on issues related to indigenous rights, its narrow focus on plurinationality and indigenous vindication has restricted its political incidence and capacity to represent a wider sector of the population. The indigenous rural people are the most affected by poverty and dispossession, and the unequal relations between indigenous people and mestizos have been institutionalised through the education system, the legal framework and geographic displacement (Ávalos, 2012; LópezCevallos \& Chi, 2010; Sánchez, 2006). However, focusing solely on indigenous vindication in an ethnically diverse country, like Ecuador, restrained the potentiality of the actions of CONAIE. The following paragraphs will introduce the reader to the concepts of plurinationality and interculturality.

\section{Plurinationality - An Ethnic Dimension}

[Plurinationality is] a model of political organization for the decolonization of our nations and peoples. It does not only recognize the contribution of indigenous peoples and nationalities to the Ecuadorian heritage, in relation to the cultural [and] political [aspects], but it seeks to overcome the impoverishment and discrimination that indigenous communities have faced throughout the centuries. [...] [It implies] a change in the State structure and in the economic model, [emphasising] the community self-government model and the stewardship and protection of the natural resources (CONAIE, 2007, p. 6, author's translation)

Regarding the critics of the narrow, ethnic focus of the plurinational approach, CONAIE's leaders asserted that their ideological stance is not to design a programme made by indigenous 
people for indigenous people, but for the whole country (CONAIE, 2007). However, their exclusive approach was shown in a situation recorded by Xavier Albó:

I once was in a meeting with the CONAIE [staff], and remember one black person entering [the room] and saying 'I am part of the CONAIE, I am also Indian'. But CONAIE did not understand [...] that black people also felt part of the indigenous community, and they did not accept them in the organisation. The black peoples were finally incorporated into the National Federation of Peasant, Indigenous and Black Organisations (FENOCIN). (Albó, 2008, p. 31, author's translation).

As it can be inferred, in spite of the declarations of CONAIE's leaders about the inclusiveness of their political stance, the intentions of other sectors of society in joining forces for achieving a common purpose have been evidently blocked.

\section{Interculturality - A Classist Dimension}

[Interculturality involves] the recognition of diversity, in order to build unity from within [...] It is not about indigenous vindication [over] the White (Andrango, 2012, author's translation).

Instead of focusing on the ethnicity of its members, FENOCIN focuses on common needs, such as poverty, marginalisation and exploitation, and identifies itself as the "only organisation which recognises different identities and [the inherent] interculturality at the same time" (FENOCIN, 1999, p. 59, author's translation). As stated by Manuela Cobacango, former FENOCIN president:

Interculturality aims to capture the diversity that exists in the country into concrete actions, in order to overcome the historic marginalisation and exclusion, in which [we], the exploited peoples, have lived (FENOCIN, 2008b, para. 6 author's translation)

FENOCIN is pragmatic in that it considers excluded minority groups, like indigenous, AfroEcuadorian and mestizo people; peasants, women, elder and young people (FENOCIN, 1999). Luis Andrango, current President of FENOCIN, acknowledges that there are debates about interculturality and plurinationality between the members of the federation, but notes that while interculturality is a very important topic, it is not a structural and strategic topic like the struggle for land. He further explains that the organisation is positioned towards the agrarian struggle, including topics such as land, food sovereignty, agroecology and the agrarian 
revolution. FENOCIN encourages an "equitable, transparent and continued dialog", where different interests and worldviews need to be debated and negotiated (FENOCIN, 2010, p. 135, author's translation). As it can be noted, FENOCIN's intercultural and pragmatic approaches make it relevant for the study of the institutionalisation of food sovereignty and agroecology within social movements.

\subsubsection{Structures of Representation of FENOCIN}

As pinpointed in Table 6.1, the period between 1986 and 1995 is regarded as a period of stagnation and crisis. This time span is characterised by a lack of rotation of power inside the organisation's leadership, as well as a lack of participation and even disaffiliation of half of its members: the federation's size went from 21 unions to 10 unions within 9 years (FENOCIN, 1999). Paradoxically, while the majority of its members had an indigenous background, FENOCIN was not being run according to the indigenous organisational rationale. In fact, the leadership style of indigenous communities is framed in communitarian democracy, in which the community "controls the leadership, [... and] the leaders are spokesmen of the decisions taken by the majority" (FENOCIN, 1999, p. 84, author's translation). The discussions around this topic became more relevant to members of the federation in the mid-1990s, when a participatory planning process was carried out, with support of the Paulo Freire Foundation (now the Agriterra foundation). While today, the management structures of the federation are deliberative, the vertical approach, inherited from the labour unions, restricts the participation of first-level organisations in the decisions taken at the federation level (Andrango, 2012). Notwithstanding, Luis Andrango highlights the deliberative nature of indigenous, montubio and Afro-Ecuadorian social organisations at the grassroots level. ${ }^{33}$

The indigenous social organisation, born out of kinship and derived from the Pre-Columbian Ayllu, ${ }^{34}$ required a high level of loyalty from its members (Korovkin, 2002). This aspect in turn influenced the dynamics of participation within the organisation and provided a high level of identity. Additionally, in a study conducted in Bolivia by Blair, the type of

\footnotetext{
${ }^{33}$ In Ecuador, the word montubio is used to refer to peasants or campesinos from the Coastal region of Ecuador.

${ }^{34}$ Refer to footnote 22
} 
organisation in the communities can be compared, to some extent, to a local government, in which the responsibilities of the leadership include service delivery and planning, but where there is no clear separation between the government level and civil society (in Korovkin, 2002). This is recognised as the community government model (Ibid). Fernando Prada (2005) also refers to the deliberative nature of indigenous local governance models in Bolivia, and differentiates this form of participation from the "mono-ethnic Nation-State", suggesting that the indigenous peoples have maintained the deliberative nature of the community government models throughout the years (Ibid, p. 180). Along these lines, Luis Andrango notes that,

in the countryside there is level of consciousness, which demands that if a responsibility is delegated [to a leader], this delegation has limits. This is framed by accountability and [interchange] of information. I would say that people who hold public office, and have come from a community leadership context, are more likely to stay close to the sector they represent [...] This [participatory approach] can be different in the urban context (2012, author's translation).

FENOCIN is present in 18 of the 24 provinces of Ecuador. It comprises 52 unions, which in turn group 1,300 second-level and community organisations. This structure represents around 200,000 families (FENOCIN, n.d.). FENOCIN constitutes the forth-level organisation, which gathers second and third-level organisations. As it will become clear shortly, the first-level organisations (community associations) are not represented directly within FENOCIN. Figure 6.1 displays the organisational structure of FENOCIN: 


\section{FENOCIN}

(Fourth-level

Organisation)

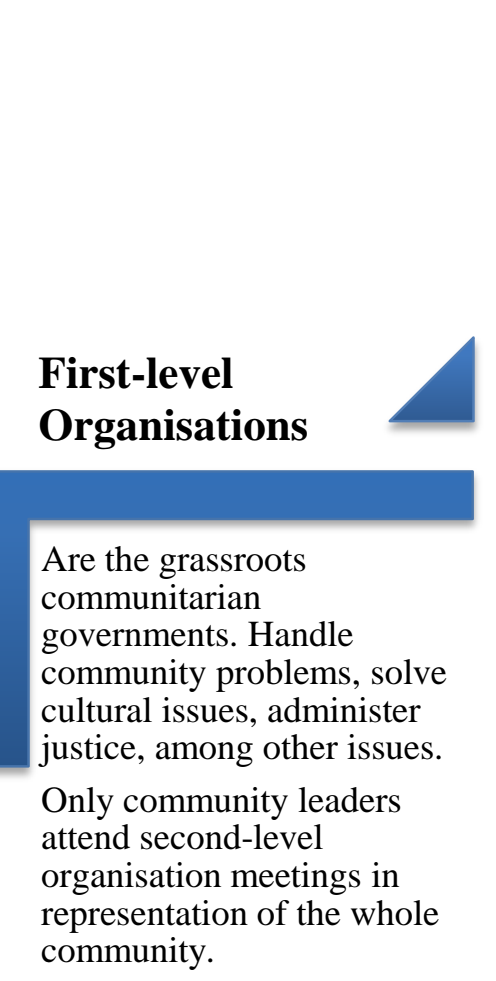

Are formed through the

grouping of between 6 and 15

communities. There are 1 or

maximum 2 second-level

organisations per municipal

jurisdiction. Their purpose is to

discuss productive, social and

economic problems at the

cantonal level. Leaders of

second-level organisations

attend third-level organisation

meetings, as well as to the

Federation's General Assembly

meetings.
Groups second- and third-

level organisations, which

have the same participation

right. First-level

organisations do not have

Also known as Federations,
are comprised of six second-

level organisations. The

board meets every month

with the purpose of handling

issues at the provincial

level. Leaders of third-level

organisations socialise with

leaders of second-level

organisations, but allegedly

not with leaders of first level

organisations. Third-level

organisations attend the

Federation's General

Assembly meetings. direct access to the 


\subsubsection{Analysis of Representativeness of FENOCIN}

There are some criticisms within FENOCIN regarding the participatory level and credibility of the third-level organisations. During casual conversations with FENOCIN's members, it was mentioned that these organisations used to have significant convening power, but lack of communication with the grassroots has negatively affected the credibility and thus, the financial support from the communities. It was stated that the representatives of first-level organisations socialise with the communities. However, decisions taken in the second-level organisation meetings, are not reciprocated by second and third-level organisations in a topdown fashion (RP-FEN-2, 2012). This phenomenon affects the quality of representativeness in FENOCIN, and consequently, some of the decisions taken do not necessarily represent the position of the grassroots. It follows then that this participatory rationale exercised in indigenous, montubio and black communities is not permeating the vertical organisational structures appropriately.

When confronted with the analysis of the participatory dynamics in the Federation, Luis Andrango, president of FENOCIN, recognised that there is some inefficiency within the structure, and underlined the necessity of facilitating communication channels in both directions, putting forward the vision and needs of communities (Andrango, 2012). He further showed commitment to the communities' perspectives and recognised the importance of incorporating their views into the decision-making process within the Federation. He also mentioned that a proposal related to the participatory structures was being constructed, which would be submitted for the consideration of the General Assembly. This proposal would consider a more horizontal management structure, and would include more people in the decision-making process.

Notwithstanding the shortcomings in the formal structures of participation, there are other communication mechanisms that allow for vertical participation and deliberation, as well as the identification of needs from the grassroots. The involvement of the technical staff of FENOCIN with the communities allows for the creation of a direct channel that can instil the organisation with the perceptions of the grassroots. Angel Cojitambo, leader of the department of Land, Territory and Environment, explains that the technical team has 
permanent communication with the community leaders, to coordinate the diverse activities carried out in the field, in the framework of community development and promotion of agroecology. The national leaders hold activities in the communities every two weeks. Additionally, publications related to best practices, systematisations of the projects and training material are released every three or six months (Cojitambo, 2012).

\subsection{The Institutionalisation of Food Sovereignty and Agroecology within FENOCIN}

The institutionalisation of food sovereignty and agroecology within the Federation has been achieved through: a) the inclusion of wider sectors of the society that have similar interests and needs, in spite of their diverse ethnic background; b) the refocus to the rural organisations and the capitalisation of community governments; c) the liaison with international NGOs that contributed with resources and facilitated the knowledge management of the lessons learnt in the field; and d) the holistic training approach adopted by FENOCIN. The following sections will present the Federation's conceptualisation of agroecology and food sovereignty, and the tools that have been implemented in order to strengthen its applicability.

\subsubsection{Conceptualisation of Food Sovereignty}

According to Luis Andrango, food sovereignty is

the right of all peoples and nations to define the land and agricultural policies, recognising peasant farming practices, defending the agroecological approach, [...], respecting the nature and providing healthy and culturally-appropriate food that was locally produced. [Under the concept of] food sovereignty, the rights of farmworkers need to be respected. [Finally, food sovereignty foresees] a commercialisation dynamic [with principles of] solidarity (2012, author's translation).

For FENOCIN, agroecology

is a [group of] principles that social organisations have formulated, which criticise monoculture production, agro-business and [extractivist] agriculture. Agroecology pursues a [...] diversified production that respects the environment and the natural life cycles. Its main purpose is to provide food for the communities, while avoiding the use of agrochemicals and defending the ancestral knowledge. [The latter] is expressed through the seeds and [the way of production utilised] by peasants. Agroecology is a form of production that gives families a life with dignity and that prevents the degradation of the soil fertility (Andrango, 2012, author's translation). 

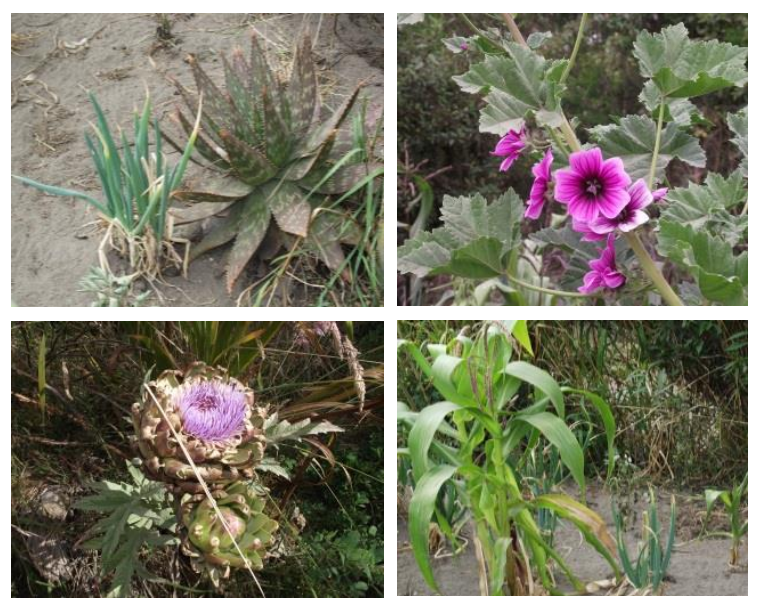

Plate 6.1: Crops and plants produced by the agroecological Chacra - Alcaluna

Association. Time of drought in the Province of Cotopaxi.

As underlined above, the ideology and political agenda of FENOCIN is centred on the agrarian struggle, as a response to the knowledge colonisation that was imposed on medium-scale farmers through the adoption of extractivist agriculture. Therefore, communities who had access to smaller portions of land survived to the influence of extractivist practices, capitalising on their ancestral knowledge. In spite of the diversity within the Federation, the unifying interests of farmers allowed for the emergence and consolidation of the concept of Dynamised Traditional Agriculture, which is FENOCIN's understanding and application of agroecology in the territories (Salgado, 2012).

\subsubsection{Tools for the Implementation of Food Sovereignty in the Field}

In 2000, with the support of the Interchurch Organization for Development Cooperation (ICCO), a project on political advocacy and peasants' rights was implemented. This project constituted the preamble for the identification of mechanisms for a cleaner, more equitable way of production that could improve the livelihoods of the rural communities. Since 2004, the Federation has actively and systematically pursued the implementation of agroecology as the way to achieve food sovereignty (RP-FEN-3, 2012). The organization Bread for the World organization is a key actor, which supported FENOCIN in this process. Since then, several activities have been put into place, according to the approaches of the CLOC and $\mathrm{La}$ Via Campesina (Ibid). As a result of the implementation of this programme,

70\% of farms belonging to FENOCIN members have adopted the agroecological approach, including agroforestry systems. [The remaining] 30\% are in transition process (RP-FEN-3, 2012). 
In fact, when asked about the constraints for the adoption of agroecology, FENOCIN technicians identified the transition process as the main concern. Luis Andrango, notes that,

we have a study which states that if a farmer wants to move away from the extractivist agriculture, his production levels will drop considerably during two or three years, which corresponds to the transition process. The [million dollar] question is who will accompany him during the transition process. After this period, through integrated management, the fertility [of the soil] is recovered, and the production levels tend to balance. But the transition period jeopardizes the survival of the peasant family" (2012, author's translation).

FENOCIN has resorted to campesino a campesino methodologies and encouraged in-situ experimentation. This has allowed for the widespread use of the practice of Dynamised Traditional Agriculture at the grassroots level. The lessons learnt generated from these experiences have been capitalised on through systematisations and other strategies for knowledge management. The Federation's approach is holistic, in which it encompasses cultural decolonisation, awareness raising, critical thinking and political education. The latter has allowed for the permeation of grassroots-born aims and discourses into local, regional and national politics. In fact the Plurinational and Intercultural Conference on Food Sovereignty (COPISA) is composed of leaders that have emerged from the grassroots and have been formed and developed in FENOCIN. COPISA is

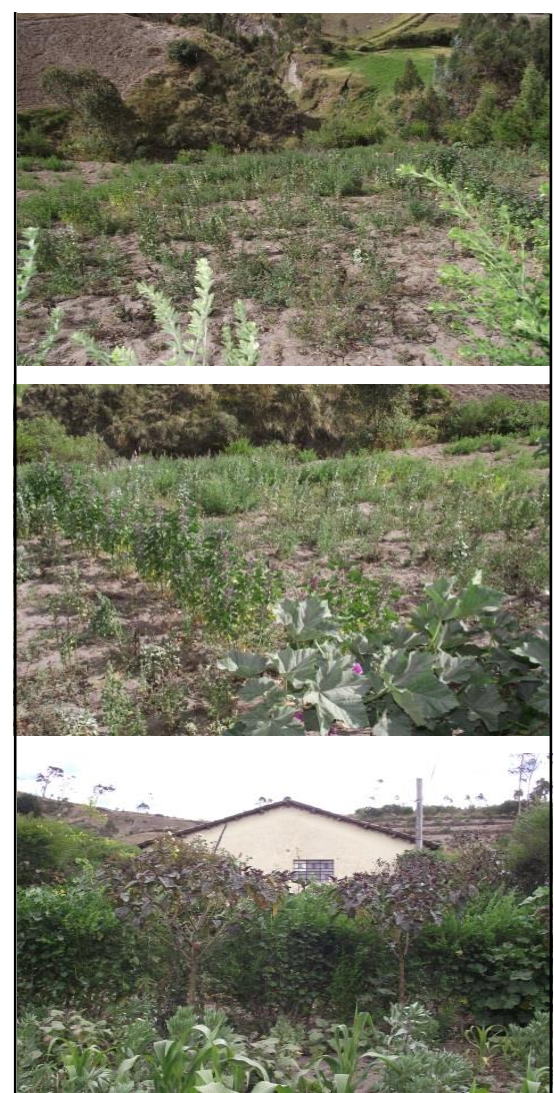

Plate 6.2: Field visit chacra Association Alcaluna. Toacaso, Province of Cotopaxi the representative body of the civil society that was in charge of leading a participatory and consensual process for the creation of the proposals for the eight complementary laws to the Law of Food Sovereignty (see Chapter 5). This aspect shows the commitment of FENOCIN to the topics of food sovereignty and agroecology, as well as its political outreach. 


\subsection{Summary}

This chapter has looked at the history of the consolidation of social movements in Ecuador, with a particular emphasis on peasant and indigenous organisations. The particular approach of FENOCIN has been delineated, so as to understand the differences between the plurinational and intercultural approaches, as well as the relation of the latter to the pursuit of food sovereignty. This chapter has also contributed to the understanding of the structures of representation of FENOCIN and its strengths and shortcomings. Finally, the aspects that have contributed to the institutionalisation of food sovereignty and agroecology within FENOCIN and the tools for the achievement of food sovereignty in the field have been elucidated. Chapter 7 will look at a case study on the implementation of food sovereignty at the grassroots level, through the analysis of a community undertaking in the Amazonian rainforest. It will complement the institutional analysis presented in this chapter. 


\section{Chapter 7}

\section{Case Study Kallari}

This chapter will present a case study on a successful initiative undertaken by a community in the northern part of the Ecuadorian Amazon rainforest. It will offer a practical example of the applicability of the concept of food sovereignty, and will be constructed through interviews with leaders, technical staff and members of Kallari. Kallari is a group of cacao producers who undertook a business initiative for the production and commercialisation of their own chocolate bar. This chapter will explore the community's journey and unveil the process in which they were able to improve their livelihoods, while at the same time maintaining their traditional practices and conserving the Amazonian rainforest. This case study will contribute to the identification and further understanding of the practice of food sovereignty in the field, and by doing so, it will address the fourth research objective.

\subsection{The Geographies of Chocolate}

Delicious chocolate bars, chocolate mousse or molten chocolate cakes do not bring to mind the citric taste of the cacao fruit, nor do these sweet treats evoke the tropical weather in which it is cultivated, the conditions in which farming communities live and cultural characteristics embedded in the cultivation process. Chocolate reminds us of everything but its origin: it elicits childhood memories, romantic occasions and special events. When our culture and geographical knowledge are strained, we associate chocolate with certain countries: Spanish style hot chocolate, Swiss smooth textured chocolate bars or Belgian liquid-centred chocolate bonbons. In the same way, cacao farmers may not be familiar with the sweet and smooth taste of chocolate. This geographical disconnection is evident not only regarding cacao and chocolate, but it is a common issue in the geographies of agro-foods (Goodman \& Goodman, 2009; Grimes, 2009; Winter, 2004). Cidell and Alberts (2006) have described the lack of mutual awareness between the actors in the two extreme points of the cacao-chocolate value chain as a double disconnect: consumers of chocolate may have never seen a cacao fruit or the tree it stems from, and farmers may have never tried a European chocolate bar. Moreover, without the connection between a product and its place of origin, the quality enjoyed in most of the chocolate products depends solely on the manufacturing process (Grimes, 2009), 
leaving aside an essential aspect: the characteristics of the farming process, the environment and the place.

The connection between the food and its place of origin has a much wider meaning because food and food production are intrinsically linked to the social and cultural values of those who grew, harvested and made it available for consumption. Through acknowledging the origin of food we are connecting it to its environment, geography and communities involved in the process. Globalisation and trade liberalisation have provided consumers around the world with the tastes, flavours and textures of distant places and geographies, satisfying the most demanding palates, or even generating new appetites for goods previously unknown. Yet, food has been commodified and hoarded, affecting its cultural symbolism and its role in social fellowship. The latter creates a cavalier relationship with food, limiting its enjoyment and cultural experience. This double disconnect is not ignored by the farmers of Kallari. When talking about chocolate producers, farmer leaders stated that:

"they lived all their lives making chocolate, but they never met the producers; they knew the dry grain, but did not know where it came from (Pozo, 2012, author's translation).

The realisation of this divide brought about a positive change for the Kallari cooperative and notable international chocolatiers, through a type of exchange between these two worlds: Kallari members attended international cacao-chocolate fairs, became aware of the operation of the chocolate business and were exposed to all the links of the chocolate value chain. On the other hand, through an internship in Kallari's headquarters, chocolatiers could visit the plantations, understand and experience first-hand the cultural and social characteristics embedded in the production of chocolate and associate the cacao fruit, the environment and the geography, with the production of chocolate and its taste.

\subsubsection{Resistance with a Chocolate Terroir}

The term terroir has been widely used to describe the specific characteristics that a geographical region offers to the cultivation and processing of wine (Vaudour, 2002). It considers the attributes that the soil, the environment, the surrounding diversity and the climate provide to the grapes, and how these particular aspects influence the taste and quality 
of the end-product. Provenance and quality are the key aspects that determine the appreciation of fine wine (Nesto, 2010). In Discovering Terroir in the World of Chocolate, Bill Nesto (2010) explored the appropriateness of the application of the concept of terroir to chocolate. He firstly examined the genetic implications of terroir in wine, and secondly scrutinised the place, location and human interaction embedded in the term.

Cross-pollination of the cacao trees result in high genetic diversity, which is expressed in pods of seeds with a different form, size and colour, as well as different genetic information (Ibid). This aspect contrasts with the genetic stability of single-varietal grapes that link wine to a particular seed and region. While this level of identification and uniqueness cannot be applied to cacao, the dimensions of location and human interaction can be compatible to those of wine, given that the origin of the cacao is known, and that the process of chocolate making has been controlled and managed from the seed to the consumers' palate. These aspects give greater importance to the farming practices, placing the farmer communities in an equally important position in the cacao-chocolate value chain. In relation to this, Nesto remarks that "[a]s in wine production, man's interaction with the raw material, in this case cacao, also shapes the final product: through the choice of when to harvest, the selection of the best cacao pods and seeds, the controlled fermentation of the sweet mucilage surrounding the seeds, and conching until the chocolate's aroma and texture reach the desired point" (Ibid, p. 135). But beyond the superior quality, the ethics behind the identification of the product's origin relate to responsible consumer practices (Grimes, 2009). More than fair trade practices consider not only the conditions during the manufacturing process, but also the impacts on the environment and on the livelihoods of the associated communities (Pozo, 2012). The Kallari chocolate is defined by their producers as "[c]hocolate that is four times as fair as 'Fair Trade",, stressing the quality of the product and the socio-economic impacts on the community (Kallari, n.d.-a).

As will become clear at the end of this chapter, the Kallari approach is compatible with the terroir concept of location and appropriation of the farming and manufacturing processes. Their particular experience has unveiled a new dimension of terroir: the resistance dimension. Resistance is understood as a dynamic and creative process that would oppose the negative effects that globalisation and the neoliberal approach have exerted on farmers of developing 
countries. Instead of contributing to an equal distribution of wealth and improving the peasants' economy, neoliberalisation has left them in oblivion, associating them with folklore and raw material production only, but not with their right to enjoy their culture, and their environment, or the right to have a prosperous rural life (Ávalos, 2012; Sánchez, 2006).

\subsection{Cacao in the Ecuadorian Economy}

The commercialisation of cacao beans and gourmet chocolate bars are the main source of income of families who are members of the Kallari cooperative (Pozo, 2012). This commodity is also an important source of income for families in the Coastal and Amazonian regions. Cacao beans - or the "golden seed", as it has been named for its relevance in the Ecuadorian economy - has been one of the most important commodities since before even the Spanish colonisation (Anecacao Ecuador, n.d.). From the mid-sixteenth century, the profitability of the cacao trade to Spain and the rest of Europe propelled the expansion of plantations along the Ecuadorian coastal region, as well as in other countries of the Americas (Anecacao Ecuador, n.d.; Grimes, 2009). By the end of the nineteenth century, Ecuador ranked as the first producer of cacao worldwide. This bonanza did not last long, due to the breakout of two cacao diseases in the 1920s: witch broom and monilia, which reduced the production rates by more than 60\% (Bentley et al., 2004; Grimes, 2009). This event marked the shift of Ecuador's economy to diversification through increased production of coffee and subsequently bananas (Vera, 2003). Table 7.1 presents the percentage share of exports of the ten leading products in Ecuador since 1970. 
Table 7.1: Export of the Ten Leading Products (1970 - 2008)

\begin{tabular}{|c|c|c|c|c|c|}
\hline Product & 1970 & 1980 & 1990 & 2000 & 2008 \\
\hline Crude petroleum & & $55 \%$ & $46 \%$ & $44 \%$ & $58 \%$ \\
\hline Bananas & $44 \%$ & $8 \%$ & $17 \%$ & $17 \%$ & $9 \%$ \\
\hline Petroleum products & & $8 \%$ & $6 \%$ & $5 \%$ & $5 \%$ \\
\hline Prepared or preserved fish & & $3 \%$ & $1 \%$ & $5 \%$ & $4 \%$ \\
\hline Crustace a and molluscs & $1 \%$ & $3 \%$ & $13 \%$ & $6 \%$ & $4 \%$ \\
\hline Cut flowers and buds for ornamental purposes & & & & $4 \%$ & $3 \%$ \\
\hline $\begin{array}{l}\text { Lorries and trucks (including ambulances, etc), } \\
\text { whether or not assembled }\end{array}$ & & & & & $1 \%$ \\
\hline Cacao beans, raw or roasted & $12 \%$ & & $3 \%$ & $1 \%$ & $1 \%$ \\
\hline Palm oil & & & & & $1 \%$ \\
\hline Fish: fresh, chilled or frozen & $1 \%$ & & $2 \%$ & $2 \%$ & $1 \%$ \\
\hline Bovine cattle (including buffaloes) & $1 \%$ & & & & \\
\hline Sugar: raw, beet and cane (not including syrups) & $4 \%$ & $2 \%$ & & & \\
\hline $\begin{array}{l}\text { Coffee, green or roasted, and coffee substitutes } \\
\text { containing coffee }\end{array}$ & $26 \%$ & $5 \%$ & $4 \%$ & & \\
\hline Cocoa paste & & $6 \%$ & $1 \%$ & & \\
\hline Cocoa butter (fat or oil) & $1 \%$ & $1 \%$ & $1 \%$ & & \\
\hline $\begin{array}{l}\text { Meat meal (including tankage), and fish meal, unfit } \\
\text { for human consumption }\end{array}$ & & $1 \%$ & & & \\
\hline Castor oil seed (excluding flour and meal) & $1 \%$ & & & & \\
\hline $\begin{array}{l}\text { Sawlogs and veneer logs, roughly squared non- } \\
\text { conifer }\end{array}$ & $2 \%$ & & & & \\
\hline $\begin{array}{l}\text { Oils and other products of the distillation of a coal } \\
\text { tar }\end{array}$ & & & & $1 \%$ & \\
\hline $\begin{array}{l}\text { Passenger motor cars (other than buses or special } \\
\text { vehicles), whether or not assembled }\end{array}$ & & & & $1 \%$ & \\
\hline Average share of leading products (\%) & $93 \%$ & $92 \%$ & $94 \%$ & $86 \%$ & $87 \%$ \\
\hline
\end{tabular}

Elaboration: Author

Source: ECLAC (n.d.-b)

As seen above, primary product exports, including oil, have played an important role in Ecuador's economy, and continue to be the most important source of income and foreign exchange. From the 1970s onwards, primary products exports have made up almost the total percentage share of exports (ECLAC, n.d.-b). Around $70 \%$ of the production of bulk cacao beans worldwide is provided by the Ivory Coast, Ghana and Indonesia. However, these countries provide less than $3 \%$ of the high quality aroma cacao. Only $5.2 \%$ of the cacao bean production worldwide corresponds to fine quality aroma cacao, and Ecuador supplies 58\% of it (Chacón et al., 2012). 
At present, cacao is still one of the top five primary-product exports, but its contribution to total exports is marginal. At the end of 2011, it represented $2.7 \%$ of primary exports, and at the end of 2012 that figure was only 1.9\% (BCE, 2012b, 2013). This might seem irrelevant from a macro-economic perspective, but from a micro-economic perspective, the gold seed is the main or only source of income of thousands of small-scale farmers. In fact, $95 \%$ of worldwide cacao production is delivered by small farms, with a size ranging between one and three hectares (Chacón et al., 2012). In Ecuador, it is estimated that around 600,000 people benefit directly from this activity that occupies 16 out of the 24 provinces of Ecuador. Kallari is one of the few associations that have taken advantage of the cacao-chocolate value chain, anchoring the cultural and environmental values of their communities, and successfully taking part in the globalised economy.

\subsection{A Thick Jungle of Green is My Home - Contextualisation of the Case Study}

\section{The Place}

The Amazonian rainforest of Ecuador is subdivided into six provinces. From North to South, the provinces are: i) Sucumbíos, ii) Napo, iii) Orellana, iv) Pastaza, v) Morona Santiago, and vi) Zamora Chinchipe. ${ }^{35}$ This case study takes place in the Province of Napo, in the northern part of the rainforest. The population of the province is 103,697 people (INEC, 2010); its surface area is $12,504 \mathrm{~km} 2$ (Calles, 2008). The weather conditions are those of a tropical humid forest, with an average temperature of $25^{\circ} \mathrm{C}$, and $90 \%$ relative humidity. This region has great biodiversity and plenty of natural resources, which range from native timber, fruit, vegetable, ornamental and medicinal species, to minerals (such as gold) and water resources. Its lush vegetation and surrounding streams and wetlands give life to a great assortment of birds, reptiles, fish and mammals, which contribute to the diversification of the food supply for the communities living in the region (Gobierno Autónomo Descentralizado Provincial de Napo, 2012).

\footnotetext{
${ }^{35}$ Refer to Figure 1.1: Political Map of Ecuador, page 20.
} 
The geography, climate and specific characteristics of the northern Ecuadorian rainforest create a peculiar, unique and vulnerable ecosystem, which is subject to threats derived from oil and timber exploitation, as well as from unsustainable cattle farming practices. The Napo province is divided into five districts or cantons, which are displayed in Figure 7.1: El Chaco, Quijos, Archidona, Tena, Cjat. This case study is conducted in the districts of Tena and part of Archidona.

\section{Figure 7.1: Political-Administrative Map of the Province of Napo}

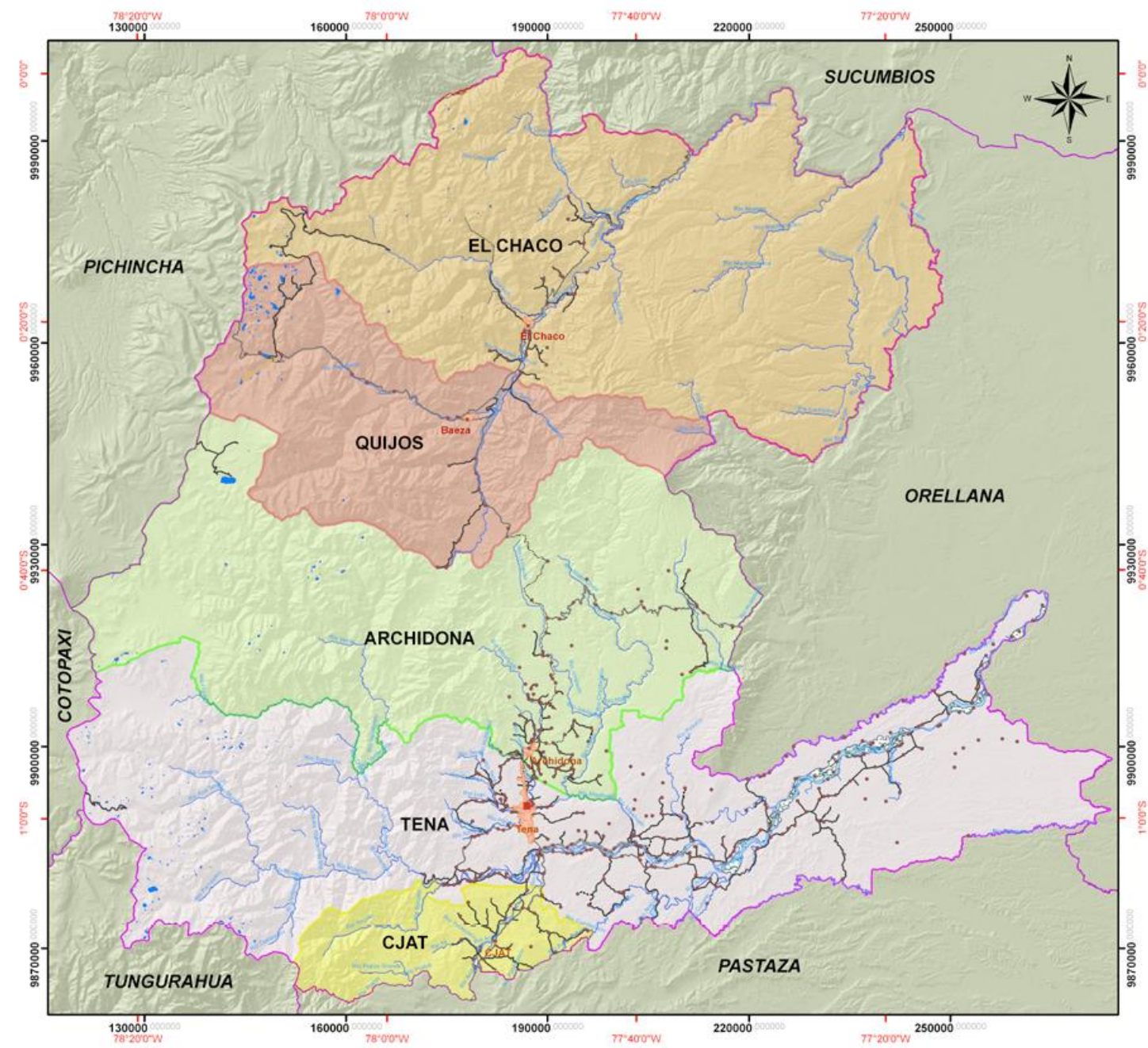

Source: Gobierno Autónomo Descentralizado Provincial de Napo (n.d.). 


\section{The People}

The Ecuadorian Amazon rainforest is inhabited by 12 indigenous nationalities, as well as the mestizo population. The indigenous nationalities are: Achuar, Andoa, Cofán, Huaorani, Kichwa, Secoya, Shiwiar, Shuar, Siona and Záparas. Additionally, the Tagaeri and Taromenane are the two last indigenous communities in Ecuador that still live in voluntary isolation (Larrea, n.d.) and derive from the Huaorani nationality. The Kichwa nationality is the largest indigenous group throughout the country, particularly in the Sierra region, but it is also the dominant ethnic group in the rainforest. Kichwa communities are to be found in the provinces of Napo, Orellana, Sucumbíos and Pastaza(CONAIE, 2011).

Tha Kichwa community of the rainforest is also called Kichwa of the lowlands and stems from ancient cultures: the Umawas and the Huitotos. Their mother language is Kichwa, even though that was not their ancestors' language. In the sixteenth century, the Spanish settlers and Catholic missionaries imposed the Kichwa language in the Amazonian region, as a mechanism to subdue some of the communities living in the northern part of the rainforest, and as a result of the use of Kichwa slaves from the highlands (Valarezo, 2002). However, the cultural differences between the diverse Kichwa groups throughout the country, and particularly between the Kichwa communities of the Sierra and the rainforest, are expressed not only in their customs and traditional rites, but also in variations of the language, as the lowland Kichwa dialect differs slightly from the Sierra Kichwa (RP-NGO-5, 2012).

The livelihood activities of the Napo Kichwa community have traditionally been hunting, fishing and the cultivation of swidden-based orchards (or chacras). Nonetheless, the colonisation pressure of the 1960s and the oil boom of the 1970s generated changes in their livelihoods, as well as their traditions and subsistence activities. With the increased influence from western cultures and the mingling with Ecuadorian mestizo and foreigners, Kichwa communities have found it necessary to divert their original livelihood to the timber industry, work outside the rural areas, cattle farming or to the cultivation of monocultural cash crops (such as naranjilla, coffee and cacao). ${ }^{36}$ As a consequence, they have withdrawn from

\footnotetext{
${ }^{36}$ Cattle is not appropriate to the characteristics of the tropical rainforest because it destroys the soil (Veiga, et al., 2003; Vera, 2003)
} 
traditional activities, like the cultivation of the chacra. However, the abandonment of the chacra has not only affected the food security of the families involved in these activities, but has also endangered the preservation of their customs, traditional knowledge, and the maintenance of the diversity of edible species and the associated flora and fauna.

Capitalising on the economic component of the chacras is fundamental, as the needs of the communities are blatant. Thomas Perrault (2005) suggests through a case study in the Mondayacu community in the Province of Napo that if communities have greater market integration it is more likely that they preserve the chacra biodiversity, as well as the knowledge and culture linked with them. Perrault does not base his analysis on the lens of food sovereignty and agroecology, and so suggests monoculture and cattle farming to help maintain the chacras, but the realisation that market integration is needed in order to meet the economic needs of Amazonian Kichwa farmers is crucial. This would not only benefit the families, but also the conservation of the environment. The present case study will tackle the uneconomic aspect of food sovereignty and will show that integration with the market does not jeopardise food sovereignty, if its principles and underlying components are maintained.

\subsection{Soil Preparation: Laying the Groundwork for the Kallari Cooperative}

Kallari is a cooperative formed by small producers who farm cacao beans, process them and commercialise gourmet chocolate bars, sold nationally and internationally. Due to the "neglect of the authorities, abuse by the middle man and poor technical support from NGOs, in the area of agriculture" (Pozo, 2012, author's translation), some Kichwa families in the Province of Tena decided to come together and form a cooperative. Around 50 families were part of the cooperative in its early stage. The first economic activity was the commercialisation of cacao beans, and their objective was to find a way in which they could access the market directly, avoiding the middleman, and so improving their livelihoods. However, avoiding the middleman did not solve the economic situation of farmers, for in most commodity products farmers are price takers not price makers (Grimes, 2009, p. 23). 
The pre-organisation phase was characterised by a poor coordination of activities: there was no stable medium-term commitment, and they did not have access to funding. As a consequence, the communities felt compelled to give in to the pressure of the timber industry and consequently cut down their hardwood trees. Eventually, in 1997, with the help of the foundation "Jatun Sacha", the organisation underwent a process of social strengthening and awareness of biodiversity in their region, over a period of three years (Pozo, 2012). Subsequently, Judy Longback, a NGO volunteer, supported them to distribute their cacao beans in Guayaquil, avoiding the middleman. By 2000, the internal commercialisation process, inherent to the direct selling of cacao in Guayaquil, was consolidated (Ibid).

With the help of the Ecuadorian Canadian Fund the organisation was supported in the consolidation of their organisational structure as an enterprise. This process lasted three years and in year 2003, the organisation was finally legally-established and registered with the Ministry of Industry and Productivity. During that time the farmers were trained in the management of their chacras, as well as in the fermentation process of the cacao beans, going from an uncontrolled and rudimentary fermentation, to a controlled process using fermentation boxes and controlling the temperature (Santopietro, 2008). Offering wellfermented cacao beans was an important step forward for the organisation, as it is "a process that brings out fruit and floral flavours and reduces astringency" (Ibid).

Their progress in the fermentation process would also open doors for exporting their beans and attending international cacao and chocolate fairs. They started to dream big and contacted "big league chocolate makers" (Santopietro, 2008, para. 18). In 2004 Dr Steinberg, founder of Scharffen Berger Chocolate, made the first chocolate bar with Kallari's beans and helped them to present their unique cacao beans in the "Madre Terra Conference of the Slow Group in Turin, Italy" (Ibid, para. 20). Kallari was honoured with the prestigious Presidium Award, in recognition of the quality of the cacao beans. But the dream would not stop there. The production of their own chocolate bar was the next dream. 
This project faced new obstacles. One of my interviewees recalls:

when we presented our project to produce [chocolate], everyone told us we were crazy, and that we should devote ourselves to do what we had [experience in], which was to farm. They told us that we did not have a chocolate bar recipe and that we didn't know how to market. They told us we should leave that to the big companies, which knew how to produce and market, because we did not have the capital to compete with the multinationals (RP-KAL-1, 2012, author's translation).

Through its international exposure, connections with chocolatiers around the world were made, and which resulted in the first chocolate recipe being given to Kallari members. In 2005, after travelling 12 hours by bus, they reached a community in the Sierra, called Salinas de Guaranda, where they could produce their own chocolate (Pozo, 2012; Santopietro, 2008). In the same year, Nora McDonnell, a 13-year-old North American girl, visited the Napo region as an exchange student, and told her parents, Jill and Stephen, about the Kallari community (Santopietro, 2008). Nora's family became interested in their situation and decided to support them.

The McDonnell's engagement with the Napo communities is recorded in Meg Cadoux Hirshberg's viewpoint essay The Romance of Good Deeds, where she explains how serving a higher purpose or having a philanthropic motivation while running a family business can create additional bonds within a married couple. ${ }^{37}$ Jill's enthusiasm for helping the Kallari members was transmitted to her husband, who set up a business in the United States in order to sell the Kallari chocolate. Jill, at the same time put at Kallari's disposal her skills for designing the chocolate bar packaging (Hirshberg, 2010). The couple also lent the Kallari cooperative US\$250,000 and helped them establish the Kallari Chocolate Company in New Jersey, with the aim of passing control over to them, when their leadership was ready (Santopietro, 2008). The McDonnell's support constitutes a milestone event in Kallari's history, through which the cooperative was able to hire a bigger, more suitable chocolate factory in Quito, as well as a consultant in order to learn and master the techniques of Swiss chocolate making (Ibid).

\footnotetext{
${ }^{37}$ Jil and Stephen McDonnell were running Applegate Farms, a company that is currently working with nearly 1,000 farmers who produce natural and organic meat (McDonell, n.d.)
} 
Furthermore, through specialisation and integrated management the quality of the cacao has continued to improve, to the extent that in 2007 it received the "Ark of Taste Award" by the Slow Food Group, in recognition of "its significance to the world's agricultural biodiversity and global gastronomic traditions" (Grimes, 2009, p. 28). Nowadays, Kallari's chocolate bar has consolidated its position in the North American market, and the cooperative has strengthened its foreign trade skills in order to access new markets. The income generated by this enterprise represents the main source of income of the families who have engaged into the initiative (Pozo, 2012). After considering, the early stages of the organisation, and the journey they have undergone, Carlos Pozo, General Coordinator of Kallari, noted that with hard work and cohesion, community-owned projects could be successful. He further remarked that:

they should know that it is possible! Because people still do not believe in what can be done. In us, for example, they never believed (2012, author's translation).

\subsection{The Philosophy of Kallari}

[The name] Kallari also reflects our hopes for the future: the survival of our culture and the conservation of our rainforest (Kallari, n.d.-b).

During conversations conducted with Kallari members, it became clear that they endeavour to maintain the natural resources of the area, as well as to enhance and restore degraded areas. They are aware that taking care of the rainforest impacts positively on the fight against global warming. They have also expressed the importance of maintaining tradition, culture and customs, which have been imbued in their products, giving them a unique characteristic and an added value. Due to the chacra way of production, the chocolate bar represents not only the outstanding quality of the beans, but also the variety of natural products that surround the community. Kallari's philosophy and focus on biodiversity has turned into their business strategy, as they seek to:

potentiate all the products on [our] chacras, and manage the value chain of other [products], so as to generate additional income. [In this way] families will not depend solely on cacao, because if so, [there is the risk of] it turning into a monoculture. But through a monoculture, there is no possibility of having food security with the products available in our chacras, and we would have to sell the cacao beans and with that try to buy all the food we need and which [paradoxically] could have been obtained from our chakra (Pozo, 2012, author's translation). 
The Kichwa communities are aware of the damage to the environment through the conventional approach to agriculture. When asked about the association's position towards it, it was immediately underlined that it would have been a big mistake to have farmed a monoculture in the rainforest, due to the fragility of the soil in that region. Also, Kallari has a strong ecological approach, which includes a clear position about intergenerational equity, in that:

we have realised that our natural resources, flora and fauna are dwindling, but we cannot be selfish with the next generations. They should have the opportunity to see and experience what we have seen and experienced. This awareness needs to be taught to children, so that from an early age they value the way in which we produce and identify themselves with our products (Pozo, 2012, author's translation).

In fact, Kallari's mission does not stop at building critical consciousness within their community. They have actively promoted awareness on sustainable ways of production in schools and universities: "people need to appreciate not only the product, but how it was produced, and what this production implied" (Pozo, 2012, author's translation).

\subsection{The Concept of Food Sovereignty in the Field}

Although the terms food sovereignty and agroecology were not widely used during the interviews and field observations with members of Kallari; the concepts, principles and practices used, proved to be highly compatible with those of food sovereignty, as will become evident in the ensuing paragraphs. 


\subsubsection{The Chacra}

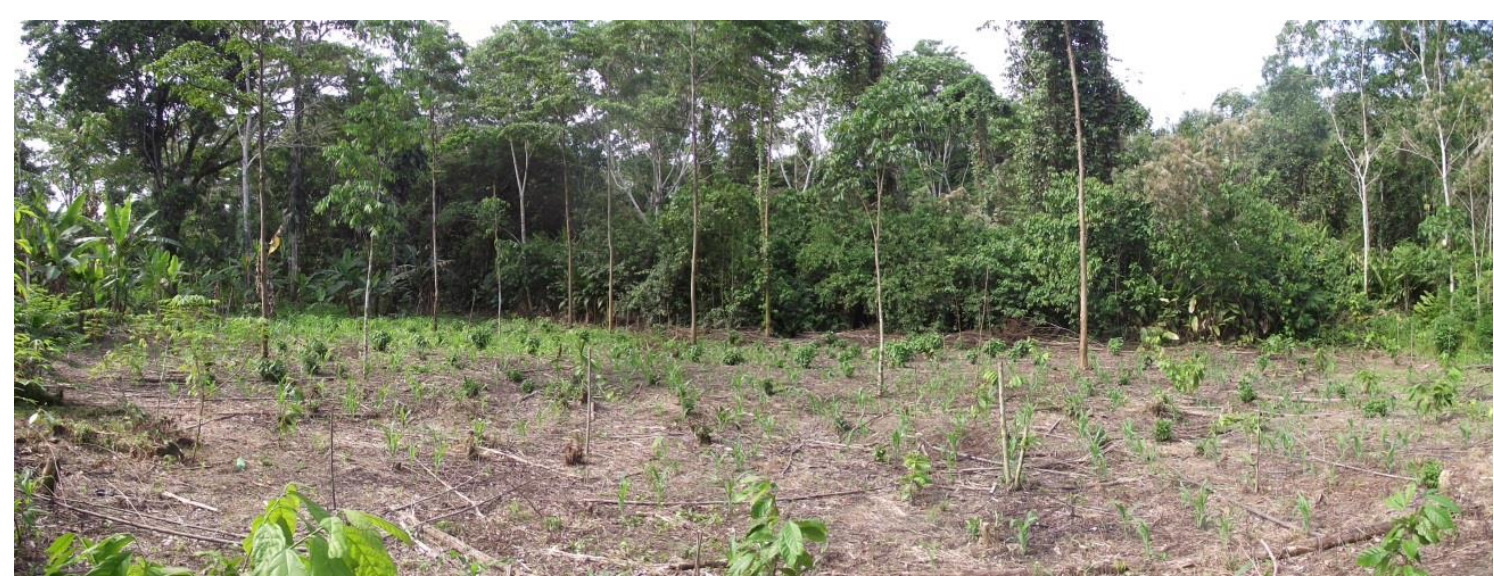

Plate 7.1: Chacra in the Amazonian rainforest, at the beginning of the planting season. Archidona, Province of Napo.

As established above, in the Kichwa culture chacra means traditional or swidden-based orchard. This traditional orchard has different characteristics, depending on the geography surrounding the area, as well as cultural specificities. In this sense, chacras in the Amazonian region look different, are taken care of differently, have a different dimension and different products than in Kichwa chacras of the Sierra. The difficult conditions for accessing the rainforest, the wild nature of the environment and the brave character of the Amazonian communities, complicated the occupation of the Amazonian region firstly by Spanish colonisers and secondly by mestizos. In spite of these facts, a great portion of the Amazonian region has suffered a process of internal colonisation by Ecuadorian mestizos.

It is worthwhile noting that the conditions surrounding the communities, as well as their worldview and the intensity of their ecological approach, vary from nationality to nationality and from peoples to peoples. With regards to the variation amongst peoples, the reader should be reminded that in the Amazonian region of Ecuador, there are 10 indigenous nationalities, not to mention recent settlements of mestizos and indigenous peoples from the Sierra. This landscape makes it inappropriate to generalise the analysis of the chacras and the nature of the associative undertakings in the whole Amazonian region. Therefore, the following paragraphs present the understanding of the chacra and how this is experienced daily by Amazonian Kichwa communities. 
The chacra puts into practice a traditional, ancestral system. This system is not only related to food sovereignty, for us it also is food security. The idea is that within the chacra all the products that help feed the family are to be found. Additionally, we can also find medicinal plants for people and animals, or plants, which serve to combat diseases and pests in certain crops, such as cacao (Pozo, 2012, author's translation).

There is a great genetic diversity in cacao beans, allowed by the self-incompatibility characteristic of their plants, for which "the pollen of a given flower cannot fertilize the stamen flower" (Nesto, 2010, p. 133). This aspect places the cacao nacional variety, which is "indigenous to Ecuador" and produced in Kallari's farms, in an eminent position, for it "has lower tannin levels and is less astringent" (Grimes, 2009, pp. 26-27). However, beyond the outstanding genetic uniqueness of the nacional variety, the chacra system is the prerequisite for the exceptional quality of the cacao. The Kallari cooperative has grasped this understanding and accordingly adjusted their practices in order to assure a first-class quality.

The type of cacao is a national [and local] attribute, but the quality is given by the management the chacras, by the [harvest] and post-harvest handling, for example the fermentation and drying process, as well as the separation of the clean cacao from the cacao contaminated with monilia and witch broom (Pozo, 2012, author's translation).
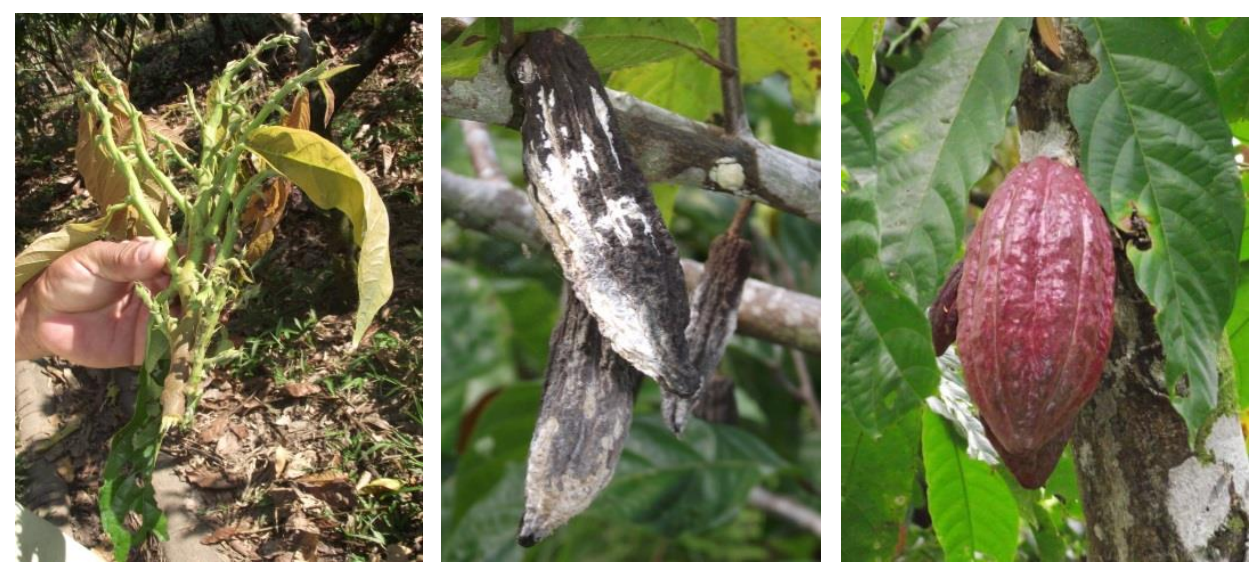

Plate 7.2: From left to right: Witch Broom; Monilia; Uncontaminated Cacao Fruit. Archidona, Province of Napo

Additionally, the chacra system allows for a high biodiversity. According to my observations in the field, different layers or strata were to be found in each chacra, comprising edible, medicinal and ornamental species, as well as timber. Kallari staff mentioned between at least 20 and 30 well-defined varieties per chacra. However, the internationally recognised high diversity of the Ecuadorian rainforests may be able to support a much higher assortment of 
flora and fauna in each chacra (Coffey et al., 2007). This again impacts on the taste and essence of the cacao offered by Kallari.

The cacao plants available in our chacras have a high genetic diversity and are also surrounded by [a natural] environment [...] This allows cacao beans to absorb flavours, both during the production and post-harvest [phases]. Cacao beans catch [surrounding] flavours. Therefore this cacao is unique and cannot be compared with [the one produced in] monocultures (Pozo, 2012, author's translation).

Notwithstanding the advantages of this system, there are some limitations that directly impact on the farmers' livelihoods, and that have not gone unnoticed by the Kichwa families. In fact, they recognise the fact that in a chacra system it is not possible to have the same productivity, measured by the number of tons, per hectare, per year.

But the chacra has many perks, and if we were to value its economic benefits, the results would be reasonably high. Therefore this [type of production] has no comparison with the conventional [production]. Besides, this approach guarantees the food provision for the family (Pozo, 2012, author's translation).

Through a monoculture-based production in the coastal area of Ecuador, the average yield is at least 1.5 tons per hectare per year, whereas in the Kallari chacra system, the number of tons produced will reach between 800 and $900 \mathrm{~kg}$ per hectare, per year, at the most (Pozo, 2012). Nevertheless, this circumstance does not discourage the communities who work in this project, because "the Kichwa farmer has in its chacra the grocery store, the pharmacy, raw materials for making crafts, etc." (RP-KAL-2, 2012), and so, the understanding of productivity has different nuances.

\subsubsection{Agroecology in the Amazonian Rainforest Context}

According to the information presented in the previous section, it is reasonable to assert that the chacra system is aligned with the principles of agroecology. This is especially manifested in the high biodiversity purposely maintained in the chacra, which results in natural pest control. In fact, the lack of these conditions can result in major disease outbreaks. This was experienced in the 1920s when the outbreak of cacao diseases [...] decimated the cacao nacional plantations along the Ecuadorian coast" (Grimes, 2009, p. 27), where the dominant agricultural system consists of large extensions of cacao monocultures, with a vast use of 
agro-toxics. It is noteworthy that even with the intense use of chemicals, the plagues could not be controlled and the top quality variety cacao nacional was almost lost in the country.

The isolation of the rainforest and the remote location of the communities avoided the transmission of the diseases from the coastal cacao monocultures to the wild grown cacao in the Amazonian region. Through this practical evidence it can be inferred that the principles of agroecology, traditionally practiced by the Kichwa communities of Napo, are effective in controlling plagues and enhancing the quality of the crops, plants and timber species, not to mention the potential for preserving the biodiversity of flora and fauna. However, in spite of the fact that a bio-diverse farm offers a natural safeguard to diseases, the Kallari cacao is occasionally attacked by plagues. The vast foliage that cacao trees have facilitates the creation of a microclimate, which is ideal for the reproduction of pests (RP-KAL-2, 2012). The diseases, which affect the cacao plants in this region are: monilia and witch broom. They are controlled manually. High biodiversity also provides the soil with high levels of nutrition, which in turn magnifies the nutritional quality of the cacao fruit.

This practice not only yields good results to the present generation, but also helps maintain the characteristics of the soil, making this activity sustainable in the long term. This reinforces the assertion that this enterprise supports and is based on an intergenerational approach.

We combine different types of trees in the chacra, so as to provide organic material to the soil. For example, the guaba tree is a leguminous plant which serves as food for its fruit, but which also contributes to the soil. [...] This traditional knowledge has been very helpful, through [the combination of] ancestral knowledge and technical knowledge. The technicians are local people who have been trained, so that they interlink and engage with [the farmers], and so, share and exchange knowledge (Pozo, 2012, author's translation).

Finally, another core aspect of agroecology is the provision of various nutritional sources to farming communities. In this regard, the maintenance of a multi-crop farm, as opposed to monoculture plantations, provides families with healthy, fresh and clean products, which have been produced locally and are made available directly to producers, allowing for a selfsustaining food supply. This aspect of agroecology is not limited by the variety of crops, but extends beyond vegetable and fruit species, to animal species, completing the ecological scenario. 
We like to eat chicken at least once a week, naturally produced chicken. With this experience we are showing that it is possible [to have a natural life style], not only with words, but with facts. [...] Some [farmers] have fish [...and] very few [farmers] have cattle or pigs [...] because the soil is not suitable for that (Pozo, 2012, author's translation).

It is evident that agroeocology supports the traditional production approach and way of life of the Kichwa communities associated in Kallari, especially with regard to natural pest control, maintenance of soil quality, and variety of nutritional sources.

\subsection{Analysis of the Case}

After exploring the Kallari initiative, the cultural, social and economic implications for its members, and the benefits for the conservation of a fragile and exuberant environment, this section of the chapter focuses on the identification of the aspects that contributed to Kallari's success. In order to facilitate the analysis, this section will be subdivided into four topics that have been drawn from the interaction with Kallari members and from my exposure to their environment and lifestyle: a) social fabric; b) logistical and practical aspects; c) external support; and, d) the value chain approach.

\subsubsection{Social Fabric}

The importance of social fabric, or social capital, as coined by Putnam in 1993, goes beyond the "individual benefits and microscale social relations" (Perreault, 2003, p. 329). This understanding of social capital emphasizes the importance of social agency when a higher objective requires the participation of various tiers of the society. Drawing on the work of Bourdieu (1977, 1984) and Fernández Kelly (1994), Perreault implies that cultural capital emerges from the synergies created within social capital (Perreault, 2003). The Kallari unique cultural capital, embedded in their traditions, environment and space strengthened the cohesion within their organisation, and proved to be a key aspect for their success. This was evident when Kallari faced opposition from other interest groups in the early stages of their organisation. When Kallari started avoiding the middleman for the commercialisation of cacao beans, threats from intermediaries were swift. Nevertheless "in the first years Kallari was so united that the intermediaries realized they could not break through this union" (Pozo, 
2012 author's translation). Accordingly, without a strong social fabric amongst communities, external threat can truncate even the most formidable impetus.

\subsubsection{Logistical and Practical Aspects}

One of the biggest criticisms of the agroecological approach is its alleged lack of profitability and low productivity. Accordingly, one of the key questions of the fieldwork was to find out how the logistics of the raw material supply were handled. In response to the question of whether it is possible to produce a sufficient quantity to cover the demand of the national and international market, Kallari's General Coordinator explained that the crux of the matter is having enough volume, which would stem from the association of a number of families, besides a strategic inclusion of traditional communities, who are not direct members of Kallari, but who farm under the same principles of agroecology.

We are formed of 850 families, who are direct members of the cooperative, but in addition to this, Kallari works with 1,200 families. It follows then that we have a large volume available. Within Kallari, the average of land dedicated to cacao production per family is 1.5 hectares. [...] Many people say that it is not profitable and that [this activity] cannot be the main source of the family income, but we have seen that [this activity] does guarantee [enough family income]. We have seen that if a family of six has [an appropriate extension of land] they can have enough income for its sustenance, without relying on additional support other than [the commercialisation of] cacao and the cultivation of the chacra (Pozo, 2012, author's translation).

Another aspect that was clearly essential, is the aforementioned elimination of the middleman through a high level of organisation and strong social cohesion. This factor is especially beneficial for the Kallari cooperative considering that they can set the price at which the cacao will be bought from its members. This provides for a fair price that considers the specialisation of the work, the needs of the families and the quality of the product. The quality standards imposed on the farmers are much higher, but at the same time the price paid for the cacao bought by the Kallari cooperative to its members is considerably higher than that offered in the market for raw cacao.

In regard to this point, Kallari leaders note that "when the price of the cacao or coffee beans falls, the price of the chocolate bar does not fall" (Pozo, 2012, author's translation). For this reason the cooperative can guarantee the purchase of the farmers' production at fair prices 
that allow them to provide for their families. Together with assuming the duties of the middleman, the cooperative had to consider all the logistics of transport. This matter might not be a straightforward step to take, considering the remote location of the farms and the access conditions in the rainforest, and as simple and obvious as it may sound, this is precisely one of the points that is forgotten when planning community undertakings (RP-FA3, 2012). Kallari plans the internal commercialization at least four months before the process starts, according to the market demand for the year (Pozo, 2012).

The cooperative's structure is also a key point. While most community-based organisations have a structure that represents a political leadership, and is inspired by the social and cultural dynamics of the group, Kallari's cooperative was constituted with a corporate structure from its early stage. Accordingly, their structure consists of a General Coordinator and three Directors for the fields of finance, production, and marketing and commercialisation. This is the governing body, which is elected at a general meeting and lasts three years. After that time, it can be re-elected or removed. The requirement for being a member of the directory is to be a farmer and to have cacao planted in at least half a hectare.

Kallari employees are farmers, who are also members of the cooperative. They receive a monthly salary and all the benefits by law [...] The annual profits are not distributed, because it is a seed fund, so that the cooperative is strengthened (Pozo, 2012, author's translation). ${ }^{38}$

Along with the corporate structure, the Kallari cooperative underwent a process of institutional strengthening, and thus training in areas such as leadership, administration, finance and marketing was of the utmost importance. Since the early stages of the organisation Kallari defined its vision and what it wanted to achieve, which ultimately paved the way to its success.

\footnotetext{
${ }^{38}$ According to the Ecuadorian Labour Law, employers ought to distribute $15 \%$ of the annual profits to their employees.
} 


\subsubsection{External Influence}

The external support was essential, we will not deny it (Pozo, 2012, author's translation).

While the social fabric and organisation in the Kichwa communities of the Napo region who are members of Kallari have clearly been a determining condition for their success, it is also important to acknowledge the external influence and the role that this has played during their consolidation and growth. The community leaders realised that they needed to contact farmers in other regions who were already producing on a large scale. This experience, combined with their own knowledge and adapted to the realities of their own culture and environment, constituted one of the steps undertaken during the embryonic organisation phase. In the same way, various community-based organisations from Ecuador and other countries (Perú, Costa Rica, Guatemala and Bolivia) have been welcomed by Kallari to learn from their experience (Pozo, 2012). This aspect has provided a space for exchange and dialogue, and has made it possible to maintain an open window to external influence into the organisation.

Another important aspect concerns the access to international fairs. This is precisely the way in which Kallari has been able to gain understanding about the international dynamics of the commercialisation of cacao beans and has also helped breach the double disconnect phenomena, referred to in the first section of this chapter. This international exposure broadened their perspective, expanding their dreams and objectives. However, the external support would not have been enough if there were not a strong young leadership within the organisation. Some of the Kallari members, during informal conversations and visits to their chacras mentioned that the elders did not support the initiative of moving forward to another link in the vertical integration chain: "they thought we were crazy [...]" recalls one of Kallari members (RP-KAL-1, 2012, author's translation). The young leadership was key in this process of industrialisation and opening up to external support. Their long-term vision is highly appreciated by their members at present, particularly the leaders' commitment to the future of the organisation. Finally, the support received by NGOs, consultants and families, moved by philanthropy, as elucidated in section 7.4, has clearly been key to Kallari's development and success. 


\section{Cacao Coordination Roundtable}

The Cacao Coordination Roundtable is an example of the external influence that supports coordination with local and national actors with the aim of combining similar agendas and interests. In this way, the dialogue and cooperation amongst civil society, representatives of the private and public sectors, as well as local NGOs and international actors is facilitated. It is also a space where different cultures and ethnicities come together (Chacón et al., 2012). This mechanism is a key step towards the conservation of protected areas, as it enables the consideration of diverse perspectives and the identification of common courses of action. The objective of the Cacao Coordination Roundtable is:

to innovate the governance framework for the management of the value chain of fine, aroma cacao, as well as chocolate, integrating the social, public and private sectors, respecting the Pachamama, valuing the Kichwa, Waorani and Mestizo peoples, and boosting the solidarity economy around the Sumaco Biosphere Reserve (Chacón et al., 2012, p. 7, author's translation).

This initiative for the coordination between the different links of the cacao-chocolate value chain started in 2003, with the Kallari cooperative as its main supporter. The principles under which the Roundtable is managed are consistent with the agro-biodiversity conservation, traditional production practices, promotion of intercultural cooperation, economic revitalisation, and promotion of socio-cultural synergies (Chacón et al., 2012). The roundtable is an excellent governance tool for vertical and horizontal coordination of the cacao value chain.

\subsubsection{From the Chacra to Your Palate: The Value Chain Approach}

This approach encompasses the organisation and coordination between the different actors of the cacao value chain, so as to take advantage of the processes of "production, transformation, trade and marketing [...] of agricultural products" (Springer-Heinze, n.d.). This mechanism is also a powerful tool for identifying power relations that oligopolies or other organised groups impose on less-organised segments of the chain. Depending on the economic, social and organisational conditions associated with a product, the value chain approach can take different nuances. It can take the form of a coordination board or roundtable, involving the liaison, alignment and planning between a range of actors and sectors (the Cacao 
Coordination Roundtable is a good example of this), but it can also take the form of a vertical integration, undergone by a company, in order to control and potentiate all the sub-processes or links of the chain, and better ensure the quality of the final product. In this approach, the first and most important step to take is the replacement of the middleman. For Kallari members, the underlying rationale that led them to advance towards a total vertical integration was the quest for improvement of their livelihoods, the conservation of their products and their cultural heritage (informal conversations with Kallari members). It ultimately allowed them to stop felling the forest and thereby constructing a sustainable, profitable and sociallyresponsible economic activity.

\subsection{Putting the Case Study into a Global Perspective}

Besides Kallari, there are a number of community-owned and fair trade initiatives that capitalise on high quality cacao and the niche market of high quality chocolate. Here, it is necessary to differentiate between fair trade and community-owned initiatives: fair trade normally refers to endeavours that are not fully owned by communities, but which have received, and continue receiving, external support (Lyon, 2006; Renard, 2005). In those cases, the community does not control all of the phases of the production chain, but receives a fairer price for its products. When communities in a fair trade initiative only produce primary goods, the processing and commercialisation are controlled by external actors in the fair trade chain. On the other hand, if communities offer processed goods, they generally do not control the commercialisation process, which often has an international focus (Low \& Davenport, 2005). In contrast, I call community-owned initiatives those in which all the value chain phases and production processes are stewarded by the community, relying on, and strengthening, the local labour force.

Other cacao-chocolate vertical integration initiatives found through online research are: a) Grenada Chocolate, in Grenada (http://grenadachocolate.com/index.html); b) Divine Chocolate, in Ghana (http://www.divinechocolate.com/uk/); ${ }^{39}$ c) AMMA Chocolate, in Brazil (http://www.ammachocolate.com.br/); and, d) Madécasse, in Madagascar

\footnotetext{
${ }^{39}$ Formerly Day Chocolate Company
} 
(http://madecasse.com/). All those experiences show how livelihood improvement through vertical integration is possible, even in different geographies and under different circumstances. All of them consider the environmental capacity, the communities' cultures and their organisation rationale. It has not been my intention to develop a case study on each of these initiatives, but reviewing the information available, through online research, was helpful to observe the different approaches put into practice. In the cases of Grenada, Divine and AMMA, community members supply the raw material and co-own the enterprise or are part of the governing board. Contrastingly, the case of Madécasse clearly suggests a fair trade, but not community-owned initiative.

Kallari, being the full expression of a community-owned initiative, contrasts with Madécasse: while in the case of Kallari, all the workers are part of the cooperative, all of them are cacao farmers, and all of them co-own the cooperative and take part in the general assembly; in the case of Madécasse, the CEO and the chocolatier are international experts, who offer their skills and knowledge to the service of the association. The latter has been positive for the business initiative, and according to their website, the community has been able to improve their quality of life through the generation of jobs inside the company or through complementary business branches (for example packaging). Nevertheless, it does not empower the existing leadership and hierarchical structures, so as to assimilate them into the company. Moreover, the sustainability of the whole Madécasse project could be compromised if the knowledge and empowerment of the French chocolatier and the American founders were not transferred to the community, should they not be available at any stage. In a community-owned alternative, as in the case of Kallari, the strong connection of their livelihoods with their culture, environment and customs, beyond the economic profit, is more evident. In this respect, Carlos Pozo affirmed that:

Kallari's philosophy is to maintain all the natural resources of the area, enhance and restore degraded areas, contribute to the fight against global warming, as well as maintain our tradition, culture and customs, which [ultimately has] helped us imbue value-added to our products (Pozo, 2012, author's translation).

Finally, it is Kallari's main interest to train and boost the skills of young leaders, so that the knowledge generated remains within the cooperative and enriches their future performance. 


\subsection{Summary}

This chapter has exposed how a community initiative that embeds all the components of food sovereignty can effectively improve the community's livelihoods, while conserving the fragile Amazonian rainforest ecosystem; valuing their traditional culture and knowledge; and, respecting intergenerational rights. We have explored the double disconnect between cacao producers and chocolatiers, created by the geographical and cultural divide between both groups. Additionally, the analysis of a chocolate terroir has unveiled its potentiality to oppose and resist globalisation and neo-liberalisation. Through the scrutiny of the Kallari case, we have seen that the philosophy of Kallari has been superimposed at all times by their leaders, which has allowed them to remain faithful to their social and cultural heritage. Finally, this chapter has examined the aspects that most influenced Kallari's success, and has put the Kallari case into global perspective, drawing on the evidence found in online research about similar cacao-chocolate initiatives around the world. The following chapter will draw on the analysis presented throughout this dissertation and will discuss the findings, so as to answer each of the research objectives and offer policy recommendations, according to the governance structure in Ecuador. 


\section{Chapter 8}

\section{Food Sovereignty, Livelihoods and Governance - Conclusions}

This chapter will address the most important findings of this dissertation. The first section will review each of the four research objectives that have been answered in previous chapters. This revision will lead us to the identification of two unifying themes that have arisen: the importance of food sovereignty for the livelihood improvement of farming communities, and the way in which communities can be resilient and exert their political agency through the practice of food sovereignty. In addition, three policy recommendations will be offered, derived from the analysis of the current governance framework in Ecuador and from the exploration of civil society's views. The chapter will conclude with my personal reflection on the study and the identification of further areas of research.

\subsection{Research Objectives: A Review}

In the following paragraphs, a review of the most important finding related to the research objectives will be presented. In order to do this, the research questions are reproduced for the sake of clarity.

\section{To understand how the concept of food sovereignty has been formed and has evolved over time, with a focus on Latin America and Ecuador.}

The concept of food sovereignty was launched internationally by the La Via Campesina Movement in 1996, in the World Food Summit held in Rome, Italy. This acknowledged the spread of the concept and its exploration and understanding worldwide. While this was the first time that food sovereignty was part of an international debate, farmer practices and grassroots NGOs activities had already been linked to the topic well before the 1990s. In the academic literature, for example, the term agroecology was coined by B.M. Bensin in 1928, gaining importance during the 1970s and 1980s, and achieving a greater significance in the 1990s. Through the literature survey presented in Chapter 3, the general misconception that situates food sovereignty and food security as similar terms was addressed. While food security is primarily concerned with contributing to a specific level of nutrients and calories 
for people, disregarding the wider implications of the production of food and its consumption, food sovereignty embeds socio-cultural, economic, environmental and political aspects. This thesis has also explored the damage that conventional extractivist agriculture exerts on communities and the environment. The latter was evidenced in: a) the barriers for appropriate nutrition for farmer families; b) the economic, social and cultural limitations that emerge with monoculture plantations; c) the impact on climate change, d) the effects of intensive use of agro-toxics; and, c) the widespread use of genetically modified (GM) crops.

In order to deepen the understanding of food sovereignty, I analysed the evolution of the organic movement and highlighted its similarities to the industrial extractivist approach to agriculture. Subsequently, due to its importance to the implementation of food sovereignty worldwide, section 3.4 elucidated how agroecology builds the path for the achievement of food sovereignty, through its integration of conventional science and traditional knowledge. The political component of food sovereignty at the international level was presented through a brief exploration of La Via Campesina Movement. Special emphasis was given to the practice of food sovereignty in Latin America, firstly through the exposition of three different approaches throughout the region: the campesino a campesino movement in Guatemala; the MST movement in Brazil; and the Andean region experiences; and secondly, illustrating the institutionalisation of food sovereignty through advocacy and scientific organisations, such as CLOC, MAELA and SOCLA. In order to understand the particularities of the context that frames the adoption of food sovereignty in Ecuador, Chapter 4 explored the role and nature of the agricultural sector, drawing on the areas of rural poverty, and farmers' access to productive resources, such as land, water and credit.

2. To assess the policies and governance framework relevant to food sovereignty that the Ecuadorian government put in place between 2006 and mid-2012.

In order to assess the political and governance approach of the current government in Ecuador, Chapter 5 firstly addressed the regional and historical context of the so-called turn to the left in Latin America that led to the adoption of the $21^{\text {st }}$ Century Socialism. Additionally, the concept of Sumak Kawsay, which has shaped the Ecuadorian official discourse, was elucidated to present a clear understanding of the national context that 
influenced the government's policies. This exploration led to the assessment of the legal and institutional framework for the governance of food sovereignty, with special attention to: the promotion of clean technologies; biofuels; genetically modified (GM) crops; and policies on the availability of productive resources. This analysis highlighted a number of issues:

a) Legislation: While food sovereignty, the importance of biodiversity and the genetic heritage, and the Rights of Nature are recognised in the Ecuadorian Political Constitution, the governance framework lacks the institutionalisation of participatory mechanisms in the rural areas. Likewise, the promotion of the Popular and Solidarity Economy encourages the formalisation of sectors of the economy that were primarily excluded, but does little to approach the particular necessities of farmer communities who live in remote places and have restrained access to local markets to sell their products. The Popular and Solidarity Economy should primarily address the need to commercialise the farmers' produce locally.

b) Institutional and Planning Framework: With the approval of the Organic Code of Territorial Organisation, Autonomy and Decentralisation (COOTAD), the planning framework at the national and subnational levels has improved significantly. This law has provided transparency and predictability for the process of allocating funds to subnational governments. Nevertheless, the law itself does not fully address the needs of small-scale farmers and peasant families, as it has created a generic planning framework focused on strengthening the local governments' autonomy, but with little attention to the rural areas and their need to connect to the cities.

c) Political Climate and Priority Setting: The benefits for rural development and for the institutionalisation of food sovereignty that the Organic Law of Food Sovereignty (LORSA) could help establish are unachievable if its eight complementary laws are not approved. After a deeply participatory process, led by COPISA, three bills have been presented to the legislative assembly but two issues have restrained their approval: ${ }^{40}$ i)

\footnotetext{
${ }^{40}$ Until February 2013.
} 
agro-industrial sectors with opposite interests to small-scale farmers have presented other bills to the legislative assembly addressing the same topics as the ones promoted from the grassroots; and ii) the current government does not seem to regard the approval of these laws as urgent. Thirty-four bills have been passed after the last amendment of the LORSA, but none of them have been related to the LORSA's complementary laws.

d) Agrarian Revolution Schools (ERAs): The ERAs are regarded as a revolutionary governance tool, due to their proximity to rural communities and their hands-on approach. However, while these aspects could potentially address farmers' needs, the ERAs lack of a holistic, bottom-up perspective. For instance, some ERAs are still driven by the agro industrial and extractivist rationale, which could compromise their sustainability. Additionally, a number of commentators have argued that the ERAs methodology tends to disrupt the traditional peasant organisation.

Overall, there is evidence of gaps between the discourse and action of the current government, particularly in the areas of i) promotion of clean technologies, ii) the ban of GM crops, iii) treatment of hybrid seeds, and iv) management of agro biodiversity. In these particular areas, the institutional framework and the policies adopted seem to have been designed without consideration of the wider implications for the adoption of food sovereignty or the need of self-reliance for farmer-communities. Along the same lines, the active support of megamining developments and the expansion of the oil frontier, as well as incentives to produce according to the industrial extractivist approach to agriculture, have cast doubt on the government's interest and/or understanding of the importance of food sovereignty.

3. To analyse how civil society relates to food sovereignty and how grassroots movements have exerted agency as an answer to the conditions imposed on the agro-sector, through a case study.

In order to address this objective, a case study was used to understand how social movements have confronted the conditions imposed on family farming. The case study presented in Chapter 6 addressed the formation and consolidation of the largest social movement in 
Ecuador that has institutionalised the topic of food sovereignty: the National Federation of Peasant, Indigenous and Black Organisations (FENOCIN). The Federation's wide representativeness has allowed for the capitalisation of the concept of interculturality. Its ethnic, social and cultural diversity has turned into the institution's main strength. Their vision is to fight against poverty, marginalisation and exploitation, through the agrarian struggle, which embeds areas such as land, food sovereignty, agroecology and agrarian reform (Andrango, 2012). The exploration of their structures of representation has allowed for the understanding of its significance at the local, regional and national levels in Ecuador. The connections built between the federation and the La Via Campesina's coordination body for Latin America - CLOC - has helped FENOCIN build synergies in the region and gain a deeper understanding of the peasant struggle in the international arena.

The second part of Chapter 6 addressed the way in which FENOCIN exerted agency towards the pursuit of food sovereignty. It was evident that the specific actions put in place by FENOCIN included the design and implementation of medium-term projects in the areas of political advocacy, farmers' rights, agroecological management of orchards and farms, environmental conservation, and organisational strengthening. Additionally, together with other grassroots organisations, social movements and NGOs, FENOCIN's advocacy role has exerted influence on the inclusion of food sovereignty in the Political Constitution, the approval of the LORSA and the promotion of the LORSA's eight complementary laws. Moreover, the formation of young grassroots leaders has prepared them for holding office in political and administrative public positions. Such is the case of the leaders and technical staff of the Plurinational and Intercultural Conference for Food Sovereignty (COPISA), which is leading the grassroots participatory process for the formulation of the bills of the eight complementary laws to the LORSA.

\section{To identify how the practise of food sovereignty is manifested in the field and evaluate its potentiality, through a case study.}

The practice of food sovereignty in the field was thoroughly presented in Chapter 7 through a case study that presented all the components of food sovereignty in one community initiative. The Kallari case study is an exploration of the social consolidation of a farmers' community 
in the northern Amazonian rainforest of Ecuador, and the process of resistance that led the community to undertake an innovative community-owned business model. As shown through the case study, the community improved their livelihoods considerably, and reinforced their social and cultural values; their connection to nature and their determination and agency.

I firstly presented an analysis of the geographies of chocolate, pinpointing the geographical and social double disconnect that exists between cacao farmers, chocolatiers, and chocolate consumers around the globe. A reflection about the application of the concept of chocolate terroir as a way of resistance to globalisation and the neoliberal approach was offered in the first section of Chapter 7. In order to be able to dig deeper into this case study, Kallari's growth and consolidation process was presented. From their experience it can be derived that it is possible to undertake a successful business initiative under the principles of sustainability, while responsibly utilising the rainforest and improving the community's incomes. Furthermore, their philosophy is clearly expressed throughout all the production and commercialisation phases. The survival of their culture and the conservation of their rainforest is sustained in a deep respect for tradition, culture and customs, as well as the recognition and appreciation of their uniqueness. This uniqueness has been capitalised on, so as to imbue the chocolate bar with the best characteristics of the locality, and subsequently access to and benefit from the globalised economy.

For Kallari, the particular approach to agroecology in the rainforest was implemented as an overarching principle and was materialised through the cultivation of chacras. The chacras represent biodiversity, intergenerational equity and cultural and ancestral legacy. In terms of the aspects that made the Kallari's case successful, the findings and analysis of their case show that access to land and the strong social fabric are critical conditions for a community undertaking to be sustainable, and is therefore transferable to other communities and environments. Additionally, a strong social organisation seemed to have significant importance in the ability to resolve logistical and practical aspects related to business success, such as material supply, quality control, production planning, and distribution, among others. At the same time, external support has been beneficial for the evolution of the Kallari undertaking. 


\subsection{Food Sovereignty: Two Unifying Themes}

This section will look at the aspects that were not foreseen in the research design, but that have come out through this study. The first part will look at the applicability of food sovereignty for the improvement of farmers' livelihoods, and the second part will elucidate the different forms of resistance that could be discerned through the analysis and reflection on the field data.

\subsubsection{Relevance of the Practice of Food Sovereignty for the Improvement of Farming Communities' Livelihoods}

As reviewed previously, the implementation of urban-centred and market-oriented policies during the 1970s, 1980s and 1990s resulted in the deterioration of the living conditions for rural communities, increased migration from the countryside to the cities, and worsened land hoarding (Cerrutti \& Bertoncello, 2003; Welch, 2012; Wiener Bravo, 2011). The effect of these policies continue to affect millions of people in Latin America and the Caribbean, where the rural population, in 2010 was around 125 million people $-21 \%$ of the total population in the region (ECLAC, n.d.-c). According to the Economic Commission for Latin America (ECLAC), poverty in Latin America represents $30 \%$ of the total population, and this is concentrated primarily in the rural areas, where half the population are poor and around $30 \%$ live in conditions of indigence. Ecuador is highly dependent on primary product exports, agricultural goods being one of the main components and faces a poverty level of $51 \%$ in the rural areas (INEC, 2012). Additionally, in Latin America, poverty has a strong relation to ethnicity, where indigenous people, who represent at least $40 \%$ of the population, have become the most vulnerable (World Bank, 1994). Most of them live in the rural areas (IWGIA, n.d.).

The GDP and other macroeconomic indicators, as well as a top-down approach to analysing the connection between poverty and the economy, are of little help when trying to unveil (in)equality and wealth distribution because they do not represent the conditions at the microlevel. Consequently, the improvement or worsening in the farmers' livelihoods cannot be interpreted through macro-economic data. The consideration of the dynamics at the microlevel, and with a bottom-up approach, can allow for the identification of aspects that can give 
insight into their livelihoods and quality of life. Consequently, this chapter will attempt to address the applicability and relevance of food sovereignty to improve farmer communities' livelihoods, with a bottom-up perspective. As we have seen throughout this dissertation, food sovereignty is not solely focused on potential economic benefits. Nevertheless, this aspect is of particular importance, due to the context of the rural areas of Ecuador, as presented in Chapter 4. Farmers' needs and the lack of an adequate support framework make the quest for livelihood improvement a legitimate concern in itself, which in turn is part of a holistic perspective of well-being.

The first positive impact of food sovereignty is in securing the family's nutritional requirements through natural, healthy, environmentally-friendly and culturally-appropriate food. Once farmer families are self-reliant from their food production, the income from their produce can be allocated to cover other expenses, contributing to the alleviation of poverty and malnutrition and effectively improving their livelihoods. In section 3.2 of this thesis, I argued that food sovereignty could produce adequate yield levels in order to contribute to the improvement of economic welfare while considering intergenerational equity and respecting the farmers' culture and environment. In this section I will elaborate on that assertion, drawing on all the information and evidence provided in this study. In order to do this, I will centre my analysis on two aspects that have a close relation to the economic aspect of food sovereignty: the value chain approach, and access to the market.

\section{The Value Chain Approach}

The Value Chain Approach can be regarded from two different perspectives: a coordination roundtable and business vertical integration. This section will refer to business vertical integration, which addresses the improvement of farmers' livelihoods in a direct way.

The business vertical integration approach was thoroughly presented in the case study of Kallari. As we could see, this approach not only allows communities to capitalise on all the phases of the production and commercialisation processes, so as to provide them with increased profits, but also helps to break the double disconnect that was referred to in Chapter 
7, in which chocolatiers and cacao bean producers are not familiar with each other's realities (Grimes, 2009). This contributes to better quality, single origin chocolate, under the concept of traceability. ${ }^{41}$ The first step was to replace the middleman and access the market directly, in order to sell their cacao bean produce. This action proved to be insufficient to meet their economic expectations in full, for farmers do not have bargaining power and must take any price offered by wholesalers. This is when the value chain approach comes into perspective: administering all the phases of the value chain results in more profits to the actors involved. The specialisation and industrialisation of the cooperative allowed for the assurance of the demand of the whole harvest of fine aroma cacao.

The comparative analysis of Kallari and the four other vertical integration initiatives, presented in section 7.8 emulate an "alternative glocalised version" of niche production, as opposed to neoliberal infused initiatives (Jones, 2012, p. 44). A glocalised initiative can be defined as entrepreneurship that stems from and capitalises on the local specificities of the geography, environment and culture, but which takes advantage of a globalised economy and successfully takes part in the global market (Knapp \& Herlihy, 2002). Some initiatives resort to product specialisation or geographic differentiation, which in turn requires a niche market: a distinctive clientele who would appreciate the quality and unique characteristics of the product and would therefore pay a higher price (Overton, 2010). For instance, a glocalised initiative could enable a small-scale enterprise of a "peripheral and marginalised" sector to take advantage of globalisation (Murray, 2010, p. 1). However, further research and empirical evidence have suggested some caveats to the benefits of glocalisation: fictive places have been created in the popular imagination, following business strategies that try to capitalise on the differentiation factor of glocalisation (Murray, 2006). Additionally, some top-down differentiation ventures have had negative socio-economic and environmental effects, such as the case of Fiji Water, in the Pacific (Jones, 2012).

\footnotetext{
${ }^{41}$ According to the FAO, traceability refers to "the ability to follow the movement of a food through specified stage(s) of production, processing, and distribution [...] - can be used to track products up and down the value chain. Traceability has become an integral element of national and regional food laws across the globe and is a fundamental component of the EU Rapid Alert System for Food and Feed." (Raymond, 2012, p. 220)
} 
In contrast, bottom-up initiatives, which respect, protect and at the same time capitalise on those unique features, can overcome the neoliberal, large scale approach, and have positive social, cultural, economic and environmental impacts on communities and territories. Positive environmental impacts are normally manifested in nature conservation, diversification of species and recovery of ecosystems and their components. In this way, the economic improvement of their livelihoods, through the Value Chain Approach, becomes sustainable and intergenerational, and amalgamates, rather than destroys, other components of communities' well-being.

\section{Access to the Market}

In this section, I will draw upon the experience of the farmers' association Federation of Agricultural Centres and Coastal Rural Organisations (FECAOL), which highlights the importance and meaning of having access to the market. As we will see, access to the market is not only of the highest importance for the improvement of communities' livelihoods, but for the strengthening of cultural and social values, the farmer-consumer relationship and the emotional connections that are woven between Nature, the land work and the final consumer.

Besides the double disconnect between cacao producers and chocolatiers referred to in section 7.1, Geographies of Chocolate, there seems to also be a double disconnect between urban and rural dynamics. This is evident through the lack of connection between farmers and final consumers, through the lack of awareness and sensitivity to each other's realities and limited knowledge of the effects of extractivist agriculture. During the field research, I could visit several city markets in the Provinces of Loja, Pichincha and Cotopaxi, in the Sierra region; Guayas in the Coastal region; and Zamora and Napo, in the Amazonian region. Most of the market stalls were taken by fruit and vegetable retailers. Some local governments have challenged this, especially the ones administered by indigenous leaders. However, there is still limited availability of market stalls for farmers, allowing only retail merchants to access city markets. This aspect has its roots in the cultural and social structures of racism, oppression and domination that governed the relations between indigenous people, peasants and mestizos, and which originated in the colonial and republican periods (Carrión \& Herrera, 2012). Furthermore, theories of internal colonialism, explored by Burgos Guevara (1970) in 
the case of Ecuador and Van den Berghe (1992) in Peru, among others, suggest that the ethnic domination of indigenous and peasants groups is still a latent issue (World Bank, 1994, p. 56).

FECAOL is an organisation of agroecological farmers from the Guayas province, in the Coastal region, which came together in 2003 in order to join forces to find an alternative to the extractivist approach. In spite of the constraints imposed on them by the local government, ${ }^{42}$ FECOAL conceived a way to get directly to final consumers and offer agroecological products. In association with several small farmers, and the help of NGOs, they set up two agricultural fairs: one in the most depressed and poor area of Guayaquil, and the other in one of the richest areas, which was supported by the foundation In Terris (Fundacion Interris-Balandra Cruz del Sur, 2009). The result of the fairs was so successful that farmers from the Sierra region joined, as in the case of the association of agroecological farmers Chuya Mikuna. ${ }^{43}$ This joint venture contributed to securing a steady and regular food supply to Guayaquil, with a high variety, quantity and quality of produce. In a video interview, Richard Intriago, former FECAOL President, explained that the fairs are spaces of rich and varied social interaction. He further asserted:

we want to have a relationship with the society through the sale of our food [...] food has a meaning, a culture, a peasant family behind. [...] That is why the atmosphere at the fair is festive. People talk to farmers and plenty of food is shared. Farmers also give away [some] food. [We] dance [and] laugh, like in a party. For us food sovereignty is a party, not just the sale of products (Intriago, n.d.).

As can be inferred from the above quote, livelihood improvement is only one of the farmers' concerns: the correlated benefits of the consolidation of their association and the connections built with consumers go far beyond the economic aspect. During one of the interviews, FECOAL leaders revealed that the organisation was opening a retail shop in Guayaquil in order to offer agroecological products to consumers who they had already developed a personal relationship with. These personal relationships not only made the fair more personal and entertaining, but also allowed them to undertake this initiative, knowing that they had

\footnotetext{
${ }^{42}$ Small-scale farmers could not access the local markets because they had to sell everything through a storage and distribution centre (Intriago, n.d.)

${ }^{43}$ As in the case of the association Chuya Mikuna, farmers from the Province of Cañar travel from the Sierra to the Coast to take part in the monthly fairs
} 
loyal clients who would purchase their products. Loyal clients endorse the wider significance of peasant agriculture, for "there is a peasant family behind every product" (Intriago, n.d.). Finally, FECAOL has also started to diversify their production and business branches, so as to offer processed products, such as jams, chocolate, traditional sweets, and sausages, among others (RP-FA-4, 2012).

Building up a relationship with consumers, constructing an emotional connection, and gaining their loyalty is critical to a differentiated, community-owned approach. This requires capitalisation of the initiative's uniqueness that results in consumer loyalty. Kallari's and FECAOL's initiatives considerably improved the farmers' income. In the case of FECAOL, the coming together of farmers and consumers, through the disengagement of the middleman and the understanding of each other's worlds was developed and so was the personal farmerconsumer relationship. Several interviewees agreed that building a friendly relationship was of the outmost importance and also contributed to a sustained revenue (RP-FA-4, 2012). Farmers also emphasised the fact that they felt responsible for providing fresh and healthy products to provide better nutrition to non-farming communities (RP-FA-1, 2012). This cognizance complemented the economic benefits of having broken the barriers between consumers and producers. Additionally, both, the FECAOL and Kallari experiences proved that with an appropriate coordination framework, social cohesion and community synergies, enough and steady yield levels can be achieved, allowing for constant additional income for farmers, as well as a steady food supply for final consumers. This aspect supports the assertion referred to previously that the production of adequate yield levels improves farmers' economic welfare, provided that a) the production, distribution and commercialisation processes are done in alliance with their community or association, and b) that the commercialisation process is founded on diversity and quality of the produce.

In the case of Kallari and the four other cacao-chocolate initiatives, the consumers' loyalty is based not only on the uniqueness of the product, but on the process itself and the related social impacts. It follows that the well-informed, socially-sensitive consumer is pursuing a connection that goes beyond the product. In consequence, in this type of niche market, consumers recognise a face behind the product, while also demanding high quality and uniqueness. Fair trade and similar fair initiatives go beyond raising awareness, as consumers 
feel engaged with the brand. Therefore an emotional connection to the cacao producers, the place, the realities and the culture is created. This aspect has been explored in the academic literature under the term Spatial Dynamics of Care (Goodman \& Goodman, 2009), in which labels and other communication strategies are put into place in order to "invoke an affective response" (Ibid, p. 208). As opposed to the mainstream approach of mass production and distribution, where placeless and faceless goods are commercialised in large market chains, alternative food networks are based on moral geographies linked to more distant places through ethical consumption and social justice (Ibid).

To finalise this section, it is worthwhile highlighting the relevance of food sovereignty to the improvement of farmers' livelihoods. As elucidated through the cases studies presented in this dissertation, food sovereignty goes beyond fair trade and alternative food networks, because it prompts bottom-up, community-empowered initiatives which are founded in cultural and social values of a particular context, which are revolutionary and challenge the mainstream market approach. Several elements need to be considered in order to facilitate the generation and improvement of profits for farmer communities in the countryside. We have looked in detail at the two that have come up in this thesis as the most relevant: (i) the value chain approach; and (ii) access to market. The next section will look at aspects that can help challenge the neo-liberal, market-based structures: resilience and political agency.

\subsubsection{Resilience and Political Agency through the Practice of Food Sovereignty}

Battling for food sovereignty is not only about questioning the model of commercial production, but also about recovering and valuing local knowledge and [the] family farming culture (Jalil, 2009, p. 17).

For this dissertation, I have conceptualised resistance as the group of actions that seek to avoid the effects of social, productive and commercial practices that threaten the maintenance and dispersion of small-scale agriculture, or any of its elements. These elements include the appreciation of socio-cultural values, ancestral knowledge, environmental stewardship, use of traditional seeds, among others. Additionally, resistance also refers to actions that seek to improve communities' access and control over productive resources, increase their decisionmaking power over their own territories and have influence on policy formulation. There is 
debate on the scope and dimension of resistance, and some scholars have suggested that there might be certain ambiguity or similarity with the terms compliance and ambivalence (Cupples, 2009, p. 374). Others, such as James Scott, acknowledge subtle ways of resistance. According to Scott, the hidden dimension of resistance, also called infrapolitics, can take the form of "foot dragging, petty sabotage, and feigned ignorance" (Cupples, 2009, p. 371). This suggests that resistance can take different forms, according to the culture, conditions of oppression, level of agency, actors involved and mechanisms utilised. Nevertheless, the character of the peasant struggle and social mobilisation in Ecuador is not as subtle and ambiguous as the findings of Scott in Malaysia. According to one of my interviewees, social mobilisation and resistance in Ecuador is expressed through:

ancestral knowledge [...], community governments and [through] the socio-economic relations that operate in the territories [...].Communitarian fabric persists despite all the attacks that have occurred around the world through policies [... and] market dominance (RP-NGO-2, 2012, author's translation).

As stated by a number of authors, particularly by Garrido (2012) and Altieri and Toledo (2011), political agency is part of the food sovereignty and agroecological approach. Political agency allows family farming to go beyond the production and commercialisation of quality goods for an exclusive and informed market segment, because it pursues sustainability and challenges inequality structures (Garrido Peña, 2012). Furthermore, political agency and active resistance are aspects that have repeatedly come out through this dissertation, making this topic a legitimate point of discussion and analysis. With the aim of offering clarity and keeping the analysis consistent with the findings of this study, the remainder of this section will focus on three dimensions of resistance: agroecological production; local markets and agroecological fairs; and consumer awareness.

\section{Agroecological Production}

Last week we went to Latacunga for a seed exchange [fair] and [we could] see how on one side there were peasants with little land and water, and on the other [side] large businesses with [plenty of] land fully [dedicated to] monoculture (broccoli). [They] fumigate a lot and [farm workers] get wet with those chemicals. [The large producers] do have water (RP-FA-1, 2012, author's translation). 
The first mechanism of resistance to extractivist agriculture and to the commodification of food and seeds is the maintenance of small-scale family farming through the implementation of agroecology. This has been defined by the FENOCIN as dynamised ancestral agriculture. As it has been evidenced, the cultivation of diverse crops involves the practice and further dispersal of the knowledge related to its production and harvest, as well as its traditional preparation for consumption. Here, it is again relevant to mention that food production and the act of eating are intimately connected to each other, building the perfect environment for social interaction and knowledge sharing. The action of maintaining the agroecological gardens is an example of active resistance because it allows these practices to persist throughout time, not to mention the improvement of resilience to climate change through the practice of agroecology (De Schutter, 2011).

Additionally, the maintenance of the agroecological production is also an active way to confront the socio-environmental conflicts caused by extractivist agriculture. This could also lead to the appearance of new conflicts between farmers, private corporations and the government, but as indicated by González de Molina, "environmental conflict[s] can help increase levels of sustainability of an agroecosystem or of the entire agricultural metabolism [...]" (González de Molina, 2012, p. 14, author's translation).

Finally, the on-going practice and in-situ experimentation inherent to small-scale family farming is also linked to another very important aspect related to political agency. Research and technological innovation should be part of the policy agenda for rural development; not through a top-down, but through a bottom-up approach. As recognised by Altieri and Toledo (2011), the day to day practice in the rural areas and the campesino a campesino movement offer an effective way to link research development to empirical practice (Altieri \& Toledo, 2011). 


\section{Local Markets and Agroecological Fairs}

Pressure from consumers is required (RP-FA-5, 2012, author's translation)

For agroecological family farming to survive and continue its expansion there needs to be demand from the non-farming community through the facilitation of local markets. Notwithstanding, farming communities continue to struggle with this. An agroecological community on the outskirts of the city of Cayambe, in the Sierra region, struggled to access the local market for around seven years, before they could actually have a dedicated space to offer their produce. They organised several demonstrations and created a commission to communicate their situation to the local authorities. Once the authorities accepted their requests, the farmer community faced opposition and oppression from the retail sellers who organised counterdemonstrations, and even tried to take the products from the agroecological farmers by force. One of my interviewees declared that all the effort was worthwhile because the community is already buying more land area in order to increase their production and further improve their quality of life (RP-FA-5, 2012). Nevertheless, they are aware that increased consumer awareness is needed. In order to facilitate this, the small-farmers organised a programme of visits for consumers, in the form of an "open house of the agroecological farms" (RP-FA-5, 2012, author's translation), so that consumers have the option of learning first-hand the way in which the farmers produce and what their deep connection to the environment means.

Similarly, the agroecological fair organised by FECAOL with the participation of the association Chuya Mikuna (as discussed in the previous section) has proved to be successful and beneficial for consumers and producers. Richard Intriago, one of FECAOL's leaders, states:

The impact that the fair has had is beautiful! We feel proud of our organisation. We have realised that we are creating an atmosphere of solidarity, mutual respect and admiration towards the peasant community. Other unmeasured impacts are the improvement of the children's nutrition [and] the quality of life of farmers [...] (Intriago, n.d.).

As we saw in the previous section, FECAOL decided to open the agroecological fair firstly in the poor village, because, for them, an agroecological fair is more than the commercialisation 
of products. It is about a relationship that is weaved and nurtured with the society, and about the contribution to the nutrition of poor children (Intriago, n.d.). Unlike the organic approach, which is market focused and seeks to generate "willingness to pay a price premium" (BontiAnkomah \& Yiridoe, 2006, p. 17, emphasis added), the agroecological approach is focused on "suit[ing] the needs of small-scale producers and the low-income non-farming population and oppose corporate control over production and consumption" (Altieri \& Toledo, 2011, p. 609, emphasis added).

Finally, according to the Agricultural Metabolism Theory local markets are essential to resist unsustainable agrifood systems, due to the fact that they significantly reduce the consumption of energy (Petersen, 2012). ${ }^{44}$ A study conducted in Spain shows that agriculture represents only one third of the total energy required to produce the food necessary for feeding the population, and, "[t]he remaining two thirds are used in the transportation, processing, storage and cooking required by a food chain in which there are huge distances between producers and consumers" (Manuel González de Molina in Petersen, 2012, p. 23). The latter shows that local markets and a direct farmer-consumer relationship are vital for the environmental sustainability of any food distribution system.

\section{Consumer Awareness}

As outlined previously, consumer awareness is of the utmost importance for the maintenance and consolidation of the food sovereignty approach. While consumer awareness impacts directly on the quantity of products purchased, it can also exert political pressure on authorities in order to facilitate the availability of agroecological products in fresh produce markets. Similarly, Von der Weid states that in order to achieve a change of paradigm in the agro-food systems, "appropriate national and international policies" need to be implemented (in Eggens, 2012, p. 15). For this to become effective there needs to be "very strong pressure from public opinion and social movements" (Ibid, p. 16). Along the same lines, González de Molina (2012) suggest that a more sustainable agricultural metabolism can only be achieved

\footnotetext{
${ }^{44}$ For a more in depth information about the Agricultural Metabolism Theory please refer to (Guzmán \& González de Molina, 2006)
} 
through the change of patterns at the micro-level, through the consumption of the local and seasonal produce, and the consideration of the social and cultural impacts at the time of purchase.

Small-scale farmers are not oblivious to this, and accordingly, have put into place several mechanisms to ensure they reach the consumers' attention and understanding. The Kallari cooperative has been raising awareness about environmental stewardship and the importance of appreciating the local produce in schools around their community. They are convinced that if such values are imbued in the children's hearts, they will be able to maintain those values in their adulthood (Pozo, 2012). On the other hand, FECAOL has undertaken an innovative initiative: they produce a television programme that is shown once a week, on Sunday morning at $8.00 \mathrm{am}$. The TV programme is composed of reports from several agroecological farmers, artisan producers and small-scale entrepreneurs. It also offers interviews with experts from NGOs or academia, addressing topics such as agroecological production, food sovereignty and family farming, among others.

\subsection{Policy Recommendations for the Achievement of Food Sovereignty in Ecuador}

The special rapporteur on the right to food of the United Nations, Oliver De Shutter, identified two dimensions of action related to the support of agroecological family farming: the horizontal and vertical dimensions (De Schutter, 2010). While the horizontal dimension corresponds to the widespread practice of agroecology, mainly through community work, the vertical dimension addresses the need to build a framework that supports and leads to the widespread practice of agroecology. It is in the vertical dimension of action that the government can have an active and effective role through policy formulation and the building of a structure that enables the expansion of food sovereignty. In any policy formulation the transition times and costs need to be considered, and every policy implementation should be tested and re-evaluated with the active involvement of the beneficiary group (Ibid). According to the findings of this dissertation, I will elaborate three policy recommendations: a) access to land; b) valuation of the natural heritage; and, 3) permanent platforms for participation and deliberation. 


\subsubsection{Access to Land}

Food sovereignty is related to institutional aspects, such as land distribution. Food sovereignty cannot be achieved if people, especially indigenous people and the poor, do not have access to land. The same applies to water distribution and irrigation policy (RP-NGO-4, 2012, author's translation).

As we have seen throughout the study, access to land, water and credit proved to be critical for a peasant initiative to be successful under the principles of food sovereignty. The experience of Kallari supports this assertion. In the case of Kallari, the preservation and stewardship of the productive resources of the rainforest was closely linked to their culture, traditions, their farming practices and the principles that would govern their entrepreneurship. Lack of access to resources would have resulted in lack of freedom to control and benefit from their community undertaking. Furthermore, allowing communities to steward natural resources, provides them with the framework to develop their social and cultural values, to adopt environmentally-safe practices and to address intergenerational equity, even when they have limited access to funds, technological machinery and other productive resources. This aspect was persistently emphasized by different authors, such as Altieri and Toledo (2011), Toledo (2012), Holt-Giménez (2009), Shiva (2004, 2005b), Patel (2009) and De Schutter (2011), among others. Furthermore, the local experts interviewed through the field research, such as farmers and community leaders, strengthened this assertion (Andrango, 2012; Pozo, 2012; RP-FA-5, 2012; RP-PG-2, 2012; Salgado, 2012). The analysis offered in Chapter 4 drew attention to the land tenure structure and access to credit and water in Ecuador. The land tenure structure is highly concentrated in the hands of large landowners: $16 \%$ of APUs occupy $80 \%$ of the land, and the remaining $84 \%$ of APUs access only $20 \%$ of the land (INEC, 2000).

In order to address this, the government should implement a group of policies that directly tackles the land tenure structures in the rural areas of Ecuador. While this could be controversial and generate social conflict and opposition, particularly from the socioeconomic elites, a feasible alternative would be to define limits on land ownership through a consensual process. One of the eight LORSA's complementary laws regulates the access to land, as well as its tenure and utilisation. However, the bill elaborated by civil society and facilitated by COPISA was presented to the assembly in March 2012, and as at 1 March 2013 
it had only gone through one out the five approval phases. Moreover, at the time of the presentation of the community-driven bill, four other initiatives, led by the interests of particular opposing groups, have been presented to the National Assembly.

While access to land is recognised as an indispensable condition to pursue food sovereignty, it is also widely acknowledged that such an endeavour of distributing land hoarded by large landowners and corporations is likely to generate intense social conflicts. The expected socioenvironmental conflicts that would follow land distribution efforts have been regarded as a huge hindrance for land distribution policies. One of my interviewees offered in that respect, that:

in the Latin American countries land remains a symbol of power, so it is very difficult to move the process forward. [The] political costs [are] too high for the society (RP-NGO-4, 2012, author's translation).

On the other hand, land distribution can help reduce social conflicts in the long term, while providing more freedom for poor people and social peace, through increased equality (Lipton, 2009). In regards to this, Lipton (2009) warns that "land reform that is too little, too late, [and] diverted to non-poor beneficiaries, [...] can make [social conflicts] worse [...]" (p. 60). Accordingly, it is important to consider that land distribution policies need to be transparently motivated by the fight against social inequality, and to provide compensation for land losers. Land distribution prompted by ethnic vindication has proved to arouse civil conflict (Ibid). It is important to consider that land conflicts are inherent not only in rivalry between different ethnic and social groups, but also within indigenous and farmer communities. Luis Andrango, FENOCIN president, alleged that:

one of the biggest talking points in the construction of the Land Tenure Bill is a land management model. We have realised that there is conflict in community management of land, even amongst indigenous peasant communities (2012, author's translation).

As a consequence, the government needs to engage in a process of land distribution through the establishment of limits of land ownership. However, every land re-distribution effort needs to include a consensual process that defines an appropriate land management model for each community. 


\subsubsection{Valuation of the Natural Heritage}

The political discourse has been abundant around a change of paradigm in the conceptualisation of the Ecuadorian economy, particularly after the passing of the Law for Popular and Solidarity Economy. However, little effort has been made to recognise the value of our natural heritage in the national accounts. Sustainable Economic Welfare indicators (ISEW), as well as the Sustainable GDP, offer an applicable alternative to the inclusion of nature into the assessment of the economy performance:

Sustainable Economic Welfare: This indicator seeks to assess well-being through modifications in the way GDP is calculated. The ISEW take into account the impact of past and present benefits and costs of economic activities on the environment (Lawn, 2003). Likewise, it quantifies social and environmental factors, and thus requires an additional effort in the calculation and valuation of environmental assets. However, while the ISEW considers distribution inequality and the "cost of lost natural capital services" (Lawn, 2003, p. 114), it does not calculate if "a nation's stock of natural capital has declined" (Ibid, p. 114). ${ }^{45}$ Additionally, the current calculation method assumes that consumption in general contributes to well-being, whilst in reality there are goods and consumption patterns that negatively impact on well-being. These and other criticisms on lack of theoretical foundation and the valuation methods used, have been tackled thorough analyses of theoretical and empirical applications of the ISEW in a number of countries (Lawn, 2003). The results show that while GDP indexes continually grow, the ISEW decreases, reaching values similar to those of the GDP in the 1950s or 1970s for a given country (Ibid). This index has a strong sustainability approach.

Sustainable GDP: ${ }^{46}$ this indicator is solely focused on environmental externalities and natural capital assessment. This approach advocates for the identification of a Sustainable Income that is defined "as the maximum amount of income (or consumption) in one period without depleting capital or without harming the capacity to generate the same or higher level of

\footnotetext{
${ }^{45}$ That is also the case of other indexes, such as the Genuine Progress Indicator - GPI and the Sustainable Net Benefit Index - SNBI.

${ }^{46}$ Also known as Green GDP
} 
income in future periods" (Van den Bergh, 2009, p. 133). The difficulties of this methodology in the appreciation of environmental assets have resulted in rare empirical applications, the Dutch SNI being the most famous example. ${ }^{47}$ While this index does not consider social aspects of welfare, it has a strong environmental focus, and if given an appropriate application, it has great potential to influence the adoption of a powerful sustainability policy (Ibid).

Due to the fact that the stewardship of natural resources is a cross-border issue, a level of coordination within the international community is vital (Underdal, 2010). In order to implement sustainable policies at the national level, and for these policies to be extended globally, the appropriate statistical information and welfare indexes must be used. It is crucial that policymakers are aware of the limitations of the information traditionally used for decision making and identify indexes that suit the social and environmental necessities of every country. The Ecological Footprint (Stiglitz, et al., 2009), which presents information about the resources available for production for a given population, is a useful tool that can be used in conjunction with other welfare indicators.

GDP should not be the main parameter that guides investment, debt and policy decisions. Hence, the parameters that guide decision making in public policy should be modified. In line with this, the ISEW seems to be the most appropriate alternative, due to its strong sustainability approach, its consideration of a variety of factors that affect social welfare, and its relatively simple application. Independently of the tools and indexes used for assessing income growth, ever-increasing production and consumption patterns can lead to major catastrophes in the medium and long term (IPCC, 2007; Stern, 2006). Therefore, it is deemed necessary to distinguish between current well-being and future sustainability. ${ }^{48}$ The use of suitable information is just one of the conditions for policy making to succeed. Political determination and effective horizontal and vertical coordination of sectoral policies are required. The Ecuadorian government should invest in adapting these indicators'

\footnotetext{
${ }^{47}$ SNI stands for Sustainable National Income. This Sustainable GDP application was undertaken in the Netherlands.

${ }^{48}$ Future sustainability is directly involved in the maintenance of natural, physical and human capital over time (Stiglitz, et al., 2009), and this cannot be achieved if human activities are not appropriately aligned with a sustainable development approach
} 
methodologies to the realities of the country, so that a real change of paradigm in the conceptualisation of the economy may occur. Complementary to this, raising popular awareness on sustainability and gaining cooperation of the community and key opinion leaders and institutions is critical for building a good governance framework for food sovereignty in Ecuador.

\section{The Economics of Ecosystems and Biodiversity (TEEB)}

As we have seen, one of the most important aspects that make food sovereignty possible, and which is pursued and explored through agroecology, is the maintenance of biodiversity. The Economics of Ecosystems and Biodiversity (TEEB) approach offers a range of tools to make nature's values visible. The inclusion of the valuation of nature and ecosystem services in the national economic accounts is an important step towards a more sustainable governance framework. However, the valuation methods proposed in previous paragraphs are only an example of the approaches that have extended academic and empirical scholarship. Thus, it is suggested that further exploration and development be undertaken by the Ecuadorian government. However, besides the valuation of the natural heritage of a country, it is deemed necessary to value the effects of natural resources management, so that appropriate policies may be applied. Only practical actions can help curb environmental degradation exerted by Business As Usual (BAU) activity. The TEEB approach is focused on practical actions through public policy that seek to lead to a change in the behaviour of the society. The TEEB approach is based on three steps: 1) identify and assess the ecosystem services affected;2) estimate and demonstrate the value of the ecosystem services; and 3) put into practice economically-informed policy instruments in order to target the issues identified in the first step.

The TEEB methodology seeks to assess the "changes resulting from alternative management options, rather than [...] estimate the total value of ecosystems" (TEBB, 2010, p. 11). Thus, it is important to recognise that every management option applied has limitations, and accordingly, policies and initiatives need to be re-evaluated and re-designed, through the full engagement of several actors, particularly the community primarily affected by an extractivist activity. The TEEB approach also goes beyond the valuation of the natural patrimony in the 
national accounts, in that it considers the effects of ecosystem services. For example, pollination in tropical rainforests has a significant and direct impact on the production of coffee (among other crops). Pollination services in the Indonesian Sulawesi rainforest have been valued at US\$46 per hectare. Additionally, it has been established that reduced pollination will decrease coffee yields by $18 \%$ and its revenues by $14 \%$ within two decades (TEBB, 2010, p. 16). Nevertheless, it is important to consider that the valuation and appreciation of ecosystem services, and of the natural heritage, go beyond the economic aspect. Access to environmental services has a significant impact on the socio-cultural development of a community, as well as on their self-determination and reliance. Therefore, it is necessary that the Ecuadorian government adopts the TEEB approach in public policy formulation, for the achievement of food sovereignty.

\subsubsection{Permanent Platforms for Participation and Deliberation}

Public participation processes are important for building good governance. Hence, the extent to which public opinion is taken into account in the final decisions establishes the degree in which participatory democracy is being performed. Participatory democracy differs from representative democracy in that "participatory democracy is intended to improve society by helping to redistribute power" (Durning, 1993).

There are a myriad of public participation and consultation methods that can be applied for identifying the citizens' needs. Some allow stakeholders to govern themselves and take a fully democratic decision, while others allow them to provide information and inputs that will be later considered (or not) by the authority (Durning, 1993). Participatory democracy supporters recognise deliberative processes as the best way to engage citizens (Gregory, et al., 2008). Abelson, et al (2001) have suggested several methods that offer different levels of participation and deliberation. Planning Cells is the most deliberative method proposed by Abelson et al, in which participants are directly engaged in a project or policy initiative. Other methods include focus groups, surveys and public hearings. In the following paragraphs, the governance tool known as Coordination Roundtables will be further explored, as it presents similarities to the Planning Cells approach. 
As pinpointed in the case of the Cacao Coordination Roundtable (Cacao Roundtable) reviewed in Chapter 7, this coordination mechanism can be helpful for the identification of power structures and processes that could be improved. It also facilitates dialogue, reflection, associative work and building of synergies, as well as offering advantages through empowering the community to confront and actively resist unequal power relations. In the case of the Cacao Roundtable, in the Sumaco Biosphere Reserve the rationale behind the creation of this coordination mechanism was threefold: a) the creation of synergies among actors of the value chain, through a communication channel between the private and public sector; b) fostering the sustainable production of cacao at a regional level; and c) prompting for the conservation of the Biosphere Reserve, in coordination with the different stakeholders (GIZ, 2011b)

This practical example of an inter-sectorial roundtable reflects the importance of the amalgamation of different coordination and planning levels. The private and public sector, as well as NGOs and international cooperation, need to build synergies in order to offer a focused and more effective intervention in the territories affected. Through coordination roundtables, small-scale farmers and other marginalised actors can have access to a more equalitarian framework for the development of their livelihoods. Moreover, roundtables offer a transparent perspective of all the links of the value chain to all the actors involved. While the Cacao Roundtable was initially promoted by private actors, coordination roundtables can be powerful participation and coordination mechanisms. If put into place by the Ecuadorian government, such coordination roundtables could result in a legitimate pathway and powerful tool for the formulation of public policy on food sovereignty through a highly participatory process.

\subsection{Further Areas of Research}

This study has attempted to elucidate the understandings and effects of food sovereignty, particularly on farmer communities, hence the case study approach and prioritisation of interviewees' voices and points of view. Nevertheless, little research has been done regarding international governance and its effects on food sovereignty at the national and local levels. In this respect, the policy on international trade agreements of agriculturally intensive countries 
should be reviewed and analysed through comprehensive research that includes local, national and international actors. This can be achieved through a research model founded on the Global Commodity Chain or the Global Value Chain approaches, through the lens of food sovereignty.

Additionally, while part of this dissertation has sought to identify applicable policies for the support of food sovereignty and agroecology, there is the need to further explore public policy formulation from the community perspective through the implementation of Participatory Action Research (PAR) approaches. PAR approaches enable the beneficiary group to exert their own agency and find feasible and sustainable ways to address their needs. PAR is research done by communities for communities, and has a strong political agency component. Public policy in Latin America has a top-down style and makes little effort to support and empower territories to find their own action path. However, if the government's style of authority is not participative, the findings of this study call for the urgent engagement of the scientific community in participatory research that leads to action.

\subsection{Final Remarks}

Throughout this dissertation we have explored the literature regarding the importance of food sovereignty for both the farming and non-farming communities, as well as its effects on the environment. We have also elucidated the economic, cultural, and socio-political implications of food sovereignty in the lives of small-scale farmers and civil society. The empirical component of this dissertation has deepened the understanding of how the social, cultural and political aspects of food sovereignty are expressed in the field, and it has shed light on civil society's understanding of food sovereignty. This has made it possible to analyse how the concept of food sovereignty has been adopted in Ecuador and to assess if food sovereignty is a valid concept for communities.

The findings of this study show that food sovereignty can improve the quality of life for millions of farmers, and that it is in fact applicable in rural territories. For this initiative to be successful, an appropriate governance framework needs to be established in order to challenge 
the dominant structures under which family farming has developed. There is huge opposition to this approach by a powerful minority that can only be tackled by increased citizens' awareness and by the strengthening of the social fabric among communities. Additionally, the double disconnect between the urban and the rural areas needs to be overcome through the creation of structures that allow a closer relation between local producers and consumers, such as markets of locally-produced goods.

It has become clear that the local needs have to be considered, because food sovereignty originates in the local arena. Only after satisfying the demands of the locality can it expand to regional or international levels. It is of the utmost importance to understand that there is no one size fits all approach in public policy. Agroecology and food sovereignty principles can be applied in other geographies and circumstances, but only if the actions implemented are tailored to the particularities of each community. "Agroecology is knowledge intensive" (De Schutter, 2010, p. 17), and therefore in-situ research needs to be implemented in the territories and the knowledge generated further shared through campesino a campesino movements.

My experience as a researcher has been very rewarding on a personal and professional level. My positionality has been drastically changed through conducting field research for nearly four months. This positionality shift was expressed through an increased awareness about the practical effects of market- and urban-focussed policies, as well as about the harmful effects of extractivist agriculture. This study also helped me appreciate development models that are highly respectful of cultural and environmental characteristics, and which are focused on and led by the beneficiary group. It has become clear to me that sustainability and effectiveness in policy making can only be achieved if the points of view and social agency of communities are considered. 


\title{
Appendix 1: Documentation Related to the Victoria University's Human Ethics Approval
}

\author{
VICTORIA UNIVERSITY OF WELLINGTON \\ Te Whare Wānanga o te Ūpoko o te Ika a Māui

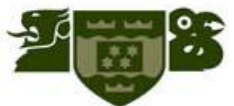

\section{PARTICIPANT INFORMATION SHEET}

\author{
Researcher: Paola Cevallos \\ Title of Project: Food Sovereignty in Ecuador - Government Policies and Governance Arrangements from \\ the perspective of the Civil Society
}

I am a Masters student in Development Studies at Victoria University of Wellington, New Zealand. As part of this degree I am undertaking a research project leading to a thesis. The project I am undertaking seeks to explore ways in which the concept of Food Sovereignty can contribute to the sustainable development of rural areas in Ecuador, through policy recommendations, but taking into account the civil society's perspective. The Human Ethics Committee of the University has approved this project.

I welcome all people who are over 18 years of age who are familiar with the topics of Food Sovereignty, Traditional Ecological Knowledge, Agro-ecology or Sustainable Rural Development. Participants will be asked to have an interview with myself discussing various questions about their perspective on rural sustainable development in Ecuador. These interviews will ask participants to discuss the status of Food Sovereignty in Ecuador and the issues related to rural sustainable development. There will be a special emphasis on the identification of the civil society's perspective and its position towards how to promote sustainable and egalitarian rural development.

The interviews are all voluntary. Participants have total power over the interview process therefore, can end the interview at any time and refuse to answer questions. I would like to record interviews so that I can use it for reference while proceeding with this study. However, I will not record the interview if you do not agree with this. Should any participants feel the need to withdraw from the interview or any information after the interview has been conducted, they may do so without question at any time before the data is analysed on the 10th August 2012. Just let me know at the time or, if later on, over email/phone.

These interviews will form the basis of my research project and will be put into a written report on a confidential basis, unless I am given permission to use your name/title. It will not be possible for you to be identified personally if you chose to not attach your name or title to your opinions. All material collected will be kept confidential. No other person besides me and my supervisor, Dr Warwick Murray, will see the results of the interviews.

All material gained from interviews will also be safeguarded at Victoria University of Wellington during the data analysis process. The thesis will be submitted for marking to the School of Geography, Environment and Earth Sciences and deposited in the University Library. It is intended that one or more articles may be submitted for publication in scholarly journals. Recordings and notes from interviews will be kept in a secure and confidential place, and only the researcher or the supervisor will have access to it.

If you have any questions or would like to receive further information about the project, please contact me at cevallpaol@myvuw.ac.nz or my supervisor, Dr Warwick Murray, at the School of Geography, Environment and Earth Sciences at Victoria University, P O Box 600, Wellington or warwick.murray@vuw.ac.nz. 


\section{VICTORIA UNIVERSITY OF WELLINGTON \\ Te Whare Wānanga o te Ūpoko o te Ika a Mãui}

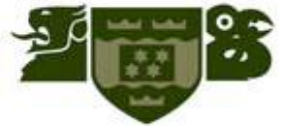

\section{HOJA DE INFORMACIÓN DEL PARTICIPANTE}

Investigadora: Paola Cevallos

Título del proyecto: Soberanía Alimentaria en Ecuador - Políticas gubernamentales y mecanismos de gobernanza, desde la perspectiva de la Sociedad Civil

Soy estudiante de la maestría en Estudios para el Desarrollo, en la Universidad Victoria de Wellington, Nueva Zelanda. Como parte de mis estudios estoy llevando a cabo un proyecto de investigación que culminará en una tesis. El objetivo de este estudio es explorar las formas en que el concepto de Soberanía Alimentaria puede contribuir al desarrollo sostenible de las zonas rurales de Ecuador, a través de recomendaciones de políticas públicas, pero teniendo en cuenta la perspectiva de la sociedad civil. El Comité de Ética de la Universidad ha aprobado este proyecto de investigación.

Doy la bienvenida a todas las personas que tengan más de 18 años de edad, y que estén familiarizados con los temas de soberanía alimentaria, el conocimiento ecológico tradicional (CET), la agroecología o el desarrollo rural sostenible. Los participantes tendrán una entrevista conmigo con el fin de discutir su perspectiva acerca del desarrollo rural sostenible en el Ecuador. En estas entrevistas se pedirá a los participantes discutir el estado de la Soberanía Alimentaria en el Ecuador y las dificultades relacionadas con el desarrollo rural sostenible. Se hará un especial énfasis en la identificación de la perspectiva de la sociedad civil y su posición con respecto a cómo se puede promover el desarrollo rural sostenible e igualitario.

Las entrevistas son voluntarias. Los participantes tienen un total dominio sobre el proceso de la entrevista, y por lo tanto pueden poner fin a la entrevista en cualquier momento y no responder a las preguntas. Me gustaría grabar las entrevistas para usarlo como referencia para la realización de este estudio. Sin embargo, no voy a grabar la entrevista si no está de acuerdo con esto. En caso de que alguno de los participantes sientan la necesidad de retirarse de la entrevista o cualquier información vertida en ésta, lo pueden hacer sin ningún cuestionamiento antes de que los datos sean analizados, esto es antes del 10 de agosto de 2012. Usted puede avisarme sobre este particular en cualquier momento durante la entrevista o posteriormente por correo electrónico o teléfono.

Estas entrevistas constituyen la base de mi proyecto de investigación y formarán parte de un informe escrito, que guardará confidencialidad, a menos que se me haya dado permiso para usar su nombre y/o título. Usted no será identificado personalmente si opta por no colocar su nombre o título en sus opiniones.

Todo el material recogido se mantendrá bajo confidencialidad. Ninguna otra persona aparte de mí y de mi supervisor, el Dr. Warwick Murray, tendrán acceso a los resultados de las entrevistas. Todo el material obtenido se mantendrá de manera segura en la Universidad Victoria de Wellington durante el proceso de análisis de la información. La tesis será entregada a la Escuela de Geografía, Medio Ambiente y Ciencias de la Tierra para su calificación y será depositada en la Biblioteca de la Universidad. Se prevé la publicación de uno o más artículos en revistas académicas. Las grabaciones y las notas de las entrevistas se mantendrán en un lugar seguro y confidencial, y sólo la investigadora o su supervisor tendrán acceso a ella.

Si tiene cualquier pregunta o quiere recibir información adicional sobre el proyecto, por favor comuníquese conmigo a cevallpaol@myvuw.ac.nz o con mi supervisor, el Dr. Warwick Murray, en la Escuela de Geografía, Medio Ambiente y Ciencias de la Tierra en la Universidad Victoria, PO Box 600, Wellington o a la dirección de correo electrónico warwick.murray@vuw.ac.nz. 


\section{VICTORIA UNIVERSITY OF WELLINGTON \\ Te Whare Wānanga o te Ūpoko o te Ika a Mãui}

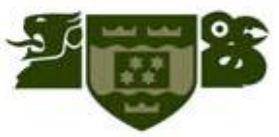

\section{CONSENT FORM - Interviews}

Food Sovereignty in Ecuador - Government Policies and Governance Arrangements from the perspective of the Civil Society

You have been asked to take part in a research study by Paola Cevallos from the School of Geography, Environment and Earth Sciences at Victoria University of Wellington (VUW), New Zealand. This study will explore ways in which the concept of Food Sovereignty can contribute to the sustainable development of rural areas in Ecuador. The results of this study will be included in Paola Cevallos' Master's thesis. It is also anticipated that the findings of the study will be written up for publication.

Please read the Participation Information Sheet, and ask questions about anything you do not understand, before deciding whether or not to take part.

\section{PERSONAL DECLARATION:}

I have been given and have understood an explanation of this research project. I understand that I may withdraw myself (or any information I have provided) from this project (before data collection and analysis is complete on the 10th August 2012) without having to give reasons or without penalty. My questions have been answered to my satisfaction, and I agree to participate in this study. I am also 18 years of age or over.

I understand that any information I provide will be kept confidential to the researcher and the supervisor and the published results will not use my name, and that no opinions will be attributed to me in any way that will identify me, unless I give permission to do so. I understand that the recording of interviews will be kept in a secure and confidential place, and only the researcher or the supervisor will have access to it. I also understand that I have the opportunity to obtain feedback when the project is complete, in the form of a summary in Spanish of the most important findings, after finishing the study, which will originally be written in English.

Please tick the appropriate boxes:

I give permission for this interview to be recorded.

$\square$ I give permission for my opinions to be recognized by:

My name $\square$ My title (i.e. Employee, Manager) $\square$ I want to be listed just as 'a participant'

I would like to be sent feedback once the project is completed.

Name and/or Title of Participant:

Signature of Participant: Date:

Please contact Paola Cevallos at cevallpaol@myvuw.ac.nz.com with any questions or my supervisor, Dr Warwick Murray, at the School of Geography, Environment and Earth Sciences at Victoria University, P O Box 600, Wellington or warwick.murray@ vuw.ac.nz. 


\section{VICTORIA UNIVERSITY OF WELLINGTON \\ Te Whare Wānanga o te Ūpoko o te Ika a Māui}

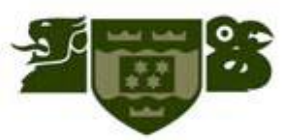

\section{HOJA DE AUTORIZACION - Entrevistas}

Soberanía Alimentaria en Ecuador - Políticas gubernamentales y mecanismos de gobernanza, desde la perspectiva de la Sociedad Civil.

A usted se le ha solicitado participar en un estudio de investigación llevado a cabo por Paola Cevallos, de la Escuela de Geografía, Medio Ambiente y Ciencias de la Tierra en la Universidad Victoria de Wellington (VUW), Nueva Zelanda. El objetivo de este estudio es explorar las formas en que el concepto de Soberanía Alimentaria puede contribuir al desarrollo sostenible de las zonas rurales de Ecuador. Los resultados de este estudio serán incluidos en la tesis de Maestría de Paola Cevallos. También se prevé que los resultados del estudio sean utilizados para publicaciones académicas. Por favor, lea la Hoja de Información y haga las preguntas necesarias sobre cualquier cosa que no entienda, antes de decidir si desea o no participar.

\section{DECLARACIÓN:}

Comprendo las explicaciones que me han sido dadas, con respecto a este proyecto de investigación. Mis preguntas han sido contestadas a mi satisfacción, y estoy de acuerdo en participar en este estudio. Entiendo que puedo retirar mi participación en este proyecto (o cualquier información que haya proporcionado) antes de la finalización de la recolección y análisis de datos (10 de agosto de 2012) sin tener que dar razones, y sin ninguna clase de penalización. Mis preguntas han sido contestadas a mi satisfacción, y estoy de acuerdo en participar en este estudio. Además declaro que soy mayor de 18 años de edad.

Entiendo que cualquier información proporcionada para el estudio de caso será confidencial entre la investigadora y su supervisor, y los resultados publicados no van a usar mi nombre. Las opiniones vertidas no se me atribuirán a mí, y la información presentada en el estudio no permitirá que se me identifique, a menos que de mi permiso para esto. Entiendo que la grabación de las entrevistas se mantendrá en un lugar seguro y confidencial, y que sólo la investigadora o su supervisor tendrán acceso a ella. También entiendo que tengo oportunidad de obtener información cuando el proyecto esté terminado, a manera de un resumen en español de los hallazgos más importantes. El estudio se escribirá originalmente en idioma inglés.

Por favor, marque las casillas correspondientes:

Doy permiso para que esta entrevista sea grabada.

Doy permiso para que mis opiniones sean identificadas con:

Mi nombre $\square$ Mi título o posición en la organización (por ejemplo, empleado/a, gerente)

Quiero aparecer como 'un participante'

Me gustaría recibir información sobre el estudio, una vez que éste sea concluido

Nombre y / o Título del participante:

Firma del participante:

Fecha:

Por favor, si tiene alguna pregunta póngase en contacto con Paola Cevallos a la dirección de correo electrónico cevallpaol@myvuw.ac.nz o con mi supervisor, el Dr. Warwick Murray, de la Escuela de Geografía, Medio Ambiente y Ciencias de la Tierra en la Universidad Victoria, PO Box 600, Wellington o warwick.murray VUW @. ac.nz. 


\section{VICTORIA UNIVERSITY OF WELLINGTON \\ Te Whare Wānanga o te Ūpoko o te Ika a Mãui}

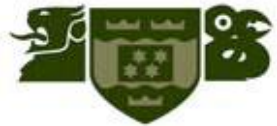

CONSENT FORM - Case Study

Food Sovereignty in Ecuador - Government Policies and Governance Arrangements from the perspective of the Civil Society

You have been asked to take part in a research study by Paola Cevallos from the School of Geography, Environment and Earth Sciences at Victoria University of Wellington (VUW), New Zealand. Through this consent form I am asking your permission to conduct a case study in the organisation you represent, in order to gain understanding of its structure and the representation rationale of people and communities involved in this organisation. For this case study I will use mainly methods as field observations, focus groups and in-depth interviews with different members of your organisation. The aim of this study is to explore ways in which the concept of Food Sovereignty can contribute to the sustainable development of rural areas in Ecuador. The results of this study will be included in Paola Cevallos' Master's thesis. It is also anticipated that the findings of the study will be written up for publication.

Please read the Participation Information Sheet, and ask questions about anything you do not understand, before deciding whether or not to take part.

\section{DECLARATION:}

I, as representative of Organisation

have been given and have understood an explanation of this research project. I understand that I may withdraw myself (or any information I have provided) from this project (before data collection and analysis is complete on the 10th August 2012) without having to give reasons or without penalty. My questions have been answered to my satisfaction, and I agree that my organisation will participate in this study. I am also 18 years of age or over.

I understand that any information provided for the case study will be kept confidential to the researcher and the supervisor and the published results will not use my name, and that no opinions will be attributed to me or any members of the organisation I represent in any way that will identify us, unless the person interviewed gives permission to do so. I understand that the recording of interviews will be kept in a secure and confidential place, and only the researcher or the supervisor will have access to it. I also understand that I have the opportunity to obtain feedback when the project is complete, in the form of a summary in Spanish of the most important findings, after finishing the study, which will originally be written in English.

Please tick the appropriate boxes:

I give permission for this interview to be recorded.

$\square$ I give permission for my opinions to be recognized by:

$\square$ My name $\square$ My title (i.e. Employee, Manager) $\quad \square$ I want to be listed just as 'a participant'

$\square$ I would like to be sent feedback once the project is completed.

Name and/or Title of Participant:

Signature of Participant:

Date:

Please contact Paola Cevallos at cevallpaol@myvuw.ac.nz with any questions or my supervisor, Dr Warwick Murray, at the School of Geography, Environment and Earth Sciences at Victoria University, P O Box 600, Wellington or warwick.murray@vuw.ac.nz. 


\section{VICTORIA UNIVERSITY OF WELLINGTON \\ Te Whare Wänanga o te Ūpoko o te Ika a Mãui

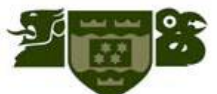

\section{HOJA DE AUTORIZACION - Estudio de caso}

Soberanía Alimentaria en Ecuador - Políticas gubernamentales y mecanismos de gobernanza, desde la perspectiva de la Sociedad Civil

A usted se le ha solicitado participar en un estudio de investigación llevado a cabo por Paola Cevallos, de la Escuela de Geografía, Medio Ambiente y Ciencias de la Tierra en la Universidad Victoria de Wellington (VUW), Nueva Zelanda. A través de esta Hoja de Autorización, pido su permiso para llevar a cabo un estudio de caso en la organización que usted representa, con el fin de comprender su estructura y lógica de representación de las personas y comunidades que son parte de esta organización. Para esto, voy a utilizar principalmente métodos como observaciones de campo, grupos focales y entrevistas a profundidad con los diferentes miembros de su organización. El objetivo de este estudio es explorar las formas en que el concepto de Soberanía Alimentaria puede contribuir al desarrollo sostenible de las zonas rurales de Ecuador. Los resultados de este estudio serán incluidos en la tesis de Maestría de Paola Cevallos. También se prevé que los resultados del estudio sean utilizados para publicaciones académicas.

Por favor, lea la Hoja de Información y haga las preguntas necesarias sobre cualquier cosa que no entienda, antes de decidir si desea o no participar.

\section{DECLARACIÓN:}

Yo, como representante de la Organización comprendo las explicaciones que me han sido dadas, con respecto a este proyecto de investigación. Entiendo que puedo retirar mi participación en este proyecto (o cualquier información que haya proporcionado) antes de la finalización de la recolección y análisis de datos (10 de agosto de 2012) sin tener que dar razones, y sin ninguna clase de penalización. Mis preguntas han sido contestadas a mi satisfacción, y estoy de acuerdo con que mi organización participe en este estudio. Además declaro que soy mayor de 18 años de edad.

Entiendo que cualquier información proporcionada para el estudio de caso será confidencial entre la investigadora y su supervisor, y los resultados publicados no van a usar mi nombre. Las opiniones vertidas no se me atribuirán a mí o a ningún miembro de la organización que represento, y la información presentada en el estudio no permitirá que se nos identifique, a menos que la persona entrevistada de su permiso para esto. Entiendo que la grabación de las entrevistas se mantendrá en un lugar seguro y confidencial, y que sólo la investigadora o su supervisor tendrán acceso a ella. También entiendo que tengo oportunidad de obtener información cuando el proyecto esté terminado, a manera de un resumen en español de los hallazgos más importantes. El estudio se escribirá originalmente en idioma inglés.

Por favor, marque las casillas correspondientes:

Doy permiso para que esta entrevista sea grabada.

Doy permiso para que mis opiniones sean identificadas con:

Mi nombre $\square$ Mi título o posición en la organización (por ejemplo, empleado/a, gerente)

Quiero aparecer como 'un participante'

Me gustaría recibir información sobre el estudio, una vez que éste sea concluido

Nombre y / o Título del participante:

Firma del participante:

Fecha:

Por favor, si tiene alguna pregunta póngase en contacto con Paola Cevallos a la dirección de correo electrónico cevallpaol@myvuw.ac.nz o con mi supervisor, el Dr. Warwick Murray, de la Escuela de Geografía, Medio Ambiente y Ciencias de la Tierra en la Universidad Victoria, PO Box 600, Wellington o warwick.murray@vuw.ac.nz. 


\section{Appendix 2: Questions Outline}

\section{Questions Outline Interviews - English}

- Are you familiar with the term of Food Sovereignty? How would you describe it?

- What are for you the main components of the term of 'Food sovereignty'?

- What is rural sustainable development for you?

- What is the ideal form of development that you would like to see in the rural area where you live? What are the main components?

- What things do you think need to change in order to pursue the way of development that you have just described?

- What do you think are the main aspects that hinder the realization of the way of development you are interested in?

- What is your perception about the current policies and governance framework in relation to rural sustainable development?

- Are there actors or institutions that you know are working to improve the development of the rural areas in Ecuador? How do they do it?

- What practical ways of improving the development of your community have been identified, and what type of support, from the national or local government do you need?

- What other aspects (laws, institutions, etc) have your community identified as critical for pursuing the development of the community you represent?

- What is your perception about the current policies and governance framework in relation to rural sustainable development? Are the current policies and structures appropriate or are they restricting a sound and equitable form of rural development?

- How should policies and structures change in order to represent the interests of your community, in relation to a more holistic, sustainable and equitable rural development?

- What mechanisms are necessary for representing the interests of your community and for enabling it to influence on policy, relating to Food Sovereignty and rural sustainable development? 


\section{Esquema de Preguntas- Español}

- Está usted familiarizado con el término de la Soberanía Alimentaria? ¿Cómo lo describiría?

- ¿Cuáles son para usted los principales componentes del término "Soberanía Alimentaria"?

- ¿Qué es el desarrollo rural sostenible para usted?

- ¿Cuál es la forma ideal de desarrollo que le gustaría ver en el área rural donde usted vive? ¿Cuáles son los principales componentes?

- ¿Qué cosas cree usted que se necesita cambiar para llegar al tipo desarrollo que usted acaba de describir?

- ¿Cuáles cree usted que son los principales aspectos que dificultan el tipo de desarrollo en el que usted está interesado?

- ¿Cuál es su percepción acerca de las actuales políticas y el marco de la gobernanza en relación con el desarrollo rural sostenible?

- ¿Existen actores o instituciones que usted sabe que están trabajando para mejorar el desarrollo de las zonas rurales en el Ecuador? ¿Cómo lo hacen?

- ¿Qué formas prácticas de mejorar el desarrollo de su comunidad han sido identificados, y qué tipo de apoyo, por parte del gobierno nacional o local, se necesita?

- ¿Qué otros aspectos (leyes, instituciones, etc) tienen su comunidad identificadas como críticas para la búsqueda del desarrollo de la comunidad que usted representa?

- ¿Cuál es su percepción acerca de las actuales políticas y el marco de la gobernanza en relación con el desarrollo rural sostenible? ¿Son las actuales políticas y de estructuras adecuadas o están restringiendo una forma racional y equitativa del desarrollo rural?

- ¿Cómo debe cambiar de políticas y estructuras con el fin de representar los intereses de su comunidad, en relación con un enfoque más holístico y sostenible y el desarrollo rural equitativo?

- ¿Qué mecanismos son necesarios para representar los intereses de su comunidad y por lo que le permite influir en la política, en relación con la soberanía alimentaria y el desarrollo rural sostenible? 


\section{Reference List}

Abelson, J., Forest, P.-G., Eyles, J., Smith, P., Martin, E., \& Gauvin, F.-P. (2001). A Review of Public Participation and Consultation Methods. Research Working Paper 01-04 (pp. 01-04). McMaster University Centre for Health Economics and Policy Analysis.

Accion Ecologica. (n.d.). ECUADOR: CRIMINALIZACIÓN DE LA PROTESTA SOCIAL EN TIEMPOS DE “REVOLUCIÓN CIUDADANA.” Accion Ecologica. Retrieved January 12, 2013, from http://www.accionecologica.org/criminalizados/articulos/1487-ecuadorcriminalizacion-de-la-protesta-social-en-tiempos-de-revolucion-ciudadana

Albó, X. (2008). Poder Indígena en Bolivia, Ecuador y Perú. In Seminario Regional Andino Democracia, Interculturalidad, Plurinacionalidad y Desafíos para la Integración Andina. Presented at the Estado Plurinacional y Construcción de una Democracia Intercultural, La Paz, Bolivia: CEBEM. Retrieved from http://www.cebem.org/cmsfiles/publicaciones/Memorias_del_seminario.pdf

Altieri, M. (2009). Agroecology, small farms, and food sovereignty. Monthly Review, 61(3), $102-113$.

Altieri, M., \& Nicholls, C. I. (2000). Teoría y práctica para una agricultura sustentable. Serie Textos Básicos para la Formación Ambiental. PNUMA. Red de Formación Ambiental para América Latina y el Caribe. México, 235. Retrieved from http://www.agro.unc.edu.ar/ biblio/AGROECOLOGIA2[1].pdf

Altieri, M., \& Toledo, V. (2011). The agroecological revolution in Latin America: rescuing nature, ensuring food sovereignty and empowering peasants. Journal of Peasant Studies, 38(3), 587-612. doi:10.1080/03066150.2011.582947

Andersson, V. (2008). Social Movements and Political Strategies. Cocaleros in Bolivia. Social Movements and/in Post-Colonial Dispossession, Development and Resistance in the Global South. Retrieved from http://www.nottingham.ac.uk/shared/shared_cssgj/Documents/smp_papers/anderson.p df

Andolina, R., Radcliffe, S., \& Laurie, N. (2005). Development and culture: Transnational identity making in Bolivia. Political Geography, 24(6), 678-702.

Andrango, L. (2012, July). Personal Communication. 
Anecacao Ecuador. (n.d.). Historia. Anecacao Ecuador - Asociacion Nacional de Exportadores de Cacao. Retrieved November 1, 2012, from http://www.anecacao.com/index.php/es/cacao-en-ecuador/historia-del-cacao.html

Anzaldúa, G. (2007). Borderlands: the New Mestiza = La Frontera (3rd ed.). San Francisco: Aunt Lute Books.

Araujo, C. (2006). The 1990 and 2001 Ecuador Poverty Maps. Excerpt of the Ecuador. Retrieved from http://siteresources.worldbank.org/INTPOVERTY/Resources/3356421300737688987/7811325-1300816522546/10412-08_p153-176.pdf

Ávalos, S. (2012). The Indigenous Quest for Power Sharing in Post-Colonial Ecuador. Intercultural Communication Studies, XXI(1), 140.

Baer, W. (1972). Import Substitution and Industrialization in Latin America: Experiences and Interpretations. Latin American Research Review, 7(1), 95-122. doi:10.2307/2502457

Barrientos Garrido, M. R. (2010). De las calles a las urnas: discurso político y estrategias identitarias del movimiento cocalero y su "instrumento político", MAS-IPSP. Retrieved from http://gredos.usal.es/jspui/handle/10366/82546

Bass, M. S., Finer, M., Jenkins, C. N., Kreft, H., Cisneros-Heredia, D. F., McCracken, S. F., ... Villa, G. (2010). Global conservation significance of Ecuador's yasuní national park. PloS one, 5(1), e8767.

BCE. (2012a). Información Estadística Mensual No. 1930 Diciembre 2012 (No. 1930). Quito, Ecuador: Banco Central del Ecuador (BCE). Retrieved from http://www.bce.fin.ec/docs.php?path=/documentos/PublicacionesNotas/Catalogo/IEM ensual/Indices/m1930122012.htm

BCE. (2012b). Cifras Económicas del Ecuador (No. Enero 2012). Quito, Ecuador: Banco Central del Ecuador (BCE). Retrieved from http://www.bce.fin.ec/documentos/Estadisticas/SectorReal/Previsiones/IndCoyuntura/ CifrasEconomicas/cie201201.pdf

BCE. (2013). Cifras Económicas del Ecuador (No. Enero 2013). Quito, Ecuador: Banco Central del Ecuador (BCE). Retrieved from http://www.bce.fin.ec/documentos/Estadisticas/SectorReal/Previsiones/IndCoyuntura/ CifrasEconomicas/cie201301.pdf

Beitcher, A. (2012). Ni La Tierra, Ni Las Mujeres Somos Territorio de La Conquista. Retrieved from http://scholarship.claremont.edu/scripps_theses/79/ 
Bentley J.W., Boa E., \& Stonehouse J. (2004). Neighbor Trees: Shade, Intercropping, and Cacao in Ecuador. Human Ecology, 32(2), 241-270. doi:10.1023/B:HUEC.0000019759.46526.4d

Blouin, C., Lemay, J.-F., Ashraf, K., Imai, J., \& Konforti, L. (2009). Local food systems and public policy: a review of the literature. Equiterre $\&$ The Centre for Trade Policy and Law. Carleton University.

Bonti-Ankomah, S., \& Yiridoe, E. K. (2006). Organic and conventional food: a literature review of the economics of consumer perceptions and preferences. Final Report. Retrieved from http://www.organicagcentre.ca/Docs/BONTI\%20\%26\%20YIRIDOE\%20April\%2028 $\% 202006 \% 20$ Final.pdf

Bourdieu, P. (1977). Outline of a theory of practice. Cambridge; New York: Cambridge University Press.

Bourdieu, P. (1984). Distinction: A Social Critique of the Judgement of Taste. Cambridge, Mass.: Harvard University Press.

Bravo, A. L. (2009). Análisis de las políticas agrícolas aplicadas en el Ecuador en los noventas desde la perspectiva de la soberanía alimentaria. Retrieved from http://www.flacsoandes.edu.ec/dspace/handle/10469/1131

Brockington, D., \& Sullivan, S. (2003). Qualitative Research. In R. Scheyvens \& D. Storey (Eds.), Development fieldwork a practical guide (pp. 57-74). London: SAGE. Retrieved from http://public.eblib.com/EBLPublic/PublicView.do?ptiID=254635

Burgos Guevara, H. (1970). Relaciones Interétnicas en Riobamba. Mexico: Instituto Indigenista Interamericano.

Bustos, B., \& Bustos, H. (2010). Hacia la soberanía alimentaria: Agroecología y comercio asociativo desde experiencias andino-amazónicas (Ediciones La Tierra., Vol. 3). Quito, Ecuador: Universidad Andina Simón Bolívar, Sede Ecuador.

Calles, J. (2008). Caracterización Ecológica de la Provincia de Napo. Fundación Ecuatoriana de Estudios Ecológicos Ecociencia. Retrieved from http://www.ecociencia.org/archivos/CaracterizacionEcologicadelaprovinciadelNapo110610.pdf 
Carbone, V. L. (2006). Cuando la Guerra Fría Llegó a América Latina - La Política Exterior Norteamericana hacia Latinoamérica durante las presidencias de Eisenhower y Kennedy (1953-1963) (Working Papers - Programa Historia de las Relaciones Internacionales No. 008). Centro Argentino de Estudios Internacionales. Retrieved from http://www.caei.com.ar/working-paper/cuando-la-guerra-fr\%C3\%ADlleg\%C3\%B3-am\%C3\%A9rica-latina-la-pol\%C3\%ADtica-exterior-norteamericanahacia

Carrión, D., \& Herrera, S. (2012). Ecuador rural del siglo XXI : soberanía alimentaria, inversión pública y política agraria. Quito: Instituto de Estudios Ecuatorianos. Retrieved from http://www.rosalux.org.ec/es/mediateca/documentos/354libroecuadorrural.html

Casado, G. G., \& Hernández, J. M. (2012). AGROECOLOGÍA Y AGRICULTURA ECOLÓGICA. APORTES Y SINERGIAS PARA INCREMENTAR LA SUSTENTABILIDAD AGRARIA. INDICE VOLUMEN 6, 6, 55-62.

Castañeda, J. G. (1990). Latin America and the End of the Cold War. World Policy Journal, 7(3), 469-492.

Castro, M. (2011). Hacia una Matriz Energética Diversificada en Ecuador. Quito: CEDA.

CBD. (n.d.). Article 2. Use of Terms. Convention on Biological Diversity (CBD). Retrieved January 16, 2013, from http://www.cbd.int/convention/articles/default.shtml?a=cbd-02

CEDA. (2012). Reflexiones en Torno al Desarrollo de los Biocombustibles en Ecuador (No. No. 25). Quito, Ecuador: Centro Ecuatoriano de Derecho Ambiental (CEDA). Retrieved from http://www.ceda.org.ec/descargas/Analisis/CEDA_analisis_No25_abril_2012_biocom bustibles_en_Ecuador.pdf

Cerrutti, M., \& Bertoncello, R. (2003). Urbanization and Internal Migration Patterns in Latin America. Centro de Estudios de Población. Argentina. Retrieved from http://pum.princeton.edu/pumconference/papers/1-cerrutti.pdf

Cevallos Cazar, P. (2012a). Sovereign Chicha: Reflections on Research Positionality. In Embodying Research in the Field. Presented at the New Zealand Geographical Society Conference 2012 - Connecting Landscapes, Napier. Retrieved from http://www.nzgs.co.nz/images/stories/nzgs/pdfs/nzgs\%20conference\%202012\%20boo k\%20of\%20abstracts\%2020121130.pdf

Cevallos Cazar, P. (2012b, September 17). How to Make Food Security Sustainable? Breaking Bread Together - A World without Hunger. Retrieved from http://socialjusticeweek.org.nz/our-daily-blog/how-to-make-food-security-sustainable/ 
Chacón, S., Cerda, L., Ramírez, P., \& Chapalbay, R. (2012). Los Rostros del Cacao Fino de Aroma en la Reserva de Biosfera Sumaco. GIZ.

Chiriboga, M., \& Wallis, B. (2010). DIAGNOSTICO DE LA POBREZA RURAL EN ECUADOR Y RESPUESTAS DE POLÍTICA PÚBLICA. Retrieved from http://www.ibcperu.org/doc/isis/13683.pdf

Cidell, J. L., \& Alberts, H. C. (2006). Constructing quality: the multinational histories of chocolate. Geoforum, 37(6), 999-1007.

doi:http://dx.doi.org/10.1016/j.geoforum.2006.02.006

CIDOB. (2013, April 8). Rafael Correa Delgado. Barcelona Centre for International Affairs (CIDOB). Retrieved January 25, 2013, from

http://www.cidob.org/documentacion/biografias_lideres_politicos/america_del_sur/ec uador/rafael_correa_delgado

CLOC. (n.d.). Quienes Somos? Coordinadora Latinoamericana de Organizaciones del Campo - CLOC. Retrieved January 24, 2013, from http://www.clocviacampesina.net/es/quienes-somos

Código Orgánico de Organización Territorial, Autnomía y Descentralización. (2010, October 19). R.O No. 303.

Coffey, G., Bravo, A. L., \& Chérrez, C. (2007). La Cosecha Perversa - El Debilitamiento de la Soberanía Alimentaria de Ecuador por las Políticas de Mercado y el Rol de las IFI. Quito: Entrepueblos : Acción Ecológica.

Cojitambo, A. (2012, July). Personal Communication.

Comunidad Andina. (2011). Agricultura familiar agroecológica campesina en la Comunidad Andina. Peru.

CONAIE. (2007). Propuesta de la CONAIE Frente a la Asamblea Constituyente - Principios y Lineamientos para la Nueva Constitución del Ecuador. CONAIE.

CONAIE. (2010, May 20). La Historia. Confederacion de Nacionalidades Indigenas del Ecuador - CONAIE. Retrieved November 15, 2012, from http://www.conaie.org/sobre-nosotros/historia

CONAIE. (2011, June 6). Kichwa Amazónico. Confederacion de Nacionalidades Indigenas del Ecuador - CONAIE. Retrieved November 15, 2012, from http://www.conaie.org/nacionalidades-y-pueblos/pueblos/amazonia/kichwaamazonico 
Constitución Política de la República del Ecuador. (2008).

Cortez, D. (2009). Genealogía del Buen Vivir en la nueva constitución ecuatoriana. In Ponencia presentada en el VIII International Congress for Intercultural Philosophy: Good life as humanized life. Concepts of good life in different cultures and their meanings for politics and societies today. Julio (Vol. 3).

Creswell, J. W. (2003). Research design: qualitative, quantitative, and mixed method approaches (2nd ed.). Thousand Oaks, Calif: Sage Publications.

Creswell, J. W. (2009). Research design: qualitative, quantitative, and mixed methods approaches (3rd ed.). Thousand Oaks, Calif: Sage Publications.

Cunningham, M. (2010). Laman Laka: Our Indigenous Path to Self-Determined Development. In V. Tauli-Corpuz, L. Enkiwe-Abayao, \& R. De Chavez (Eds.), Towards an alternative development paradigm: indigenous people's self-determined development (pp. 89-115). Baguio City, Philippines: Tebtebba Foundation.

Cupples, J. (2009). Resistance. University of Canterbury, Christchurch, New Zealand.

De Alonzo, D. (2012, June 26). Conozca la Primera Biorefinería de Biocombustibles de Segunda Generación del Ecuador. Latinoamérica Renovable. Retrieved April 1, 2012, from http://latinoamericarenovable.com/?p=1326

De David, M. B. A., Morales, C., \& Rodríguez, M. (2001). Modernidad y heterogeneidad: estilo de desarrollo agrícola y rural en América Latina y el Caribe. David, MB (comp.), Desarrollo rural en América Latina y el Caribe, Bogotá, CEPAL, Naciones Unidas. Alfaomega. Retrieved from http://biblioteca.clacso.edu.ar/ar/libros/rjave/paneles/morales.pdf

De Schutter, O. (2010). Report Submitted by the Special Rapporteur on the Right to Food (Agenda Item 3 No. A/HRC/16/49). United Nations Human Rights Council.

De Schutter, O. (2011). The Right to Food (Agenda Item 69 (b) No. A/66/262). United Nations Human Rights Council.

Diario El Comercio. (2012, February 6). El Gobierno subsidió la urea antes de su primera consulta popular. Guayaquil. Retrieved from http://www.elcomercio.com/politica/Gobierno-subsidio-primera-consultapopular_0_710929125.html 
Diario El Hoy. (2013, January 21). El Gobierno, al finalizar su mandato, saca un proyecto para la producción de urea. Retrieved from http://www.hoy.com.ec/noticiasecuador/el-gobierno-al-finalizar-su-mandato-saca-un-proyecto-para-la-produccion-deurea-572021.html

Diario El Telegrafo. (2012, December 27). Cuatro Mil Familias Beneficiadas con la Entrega de Tierras. El Telegrafo. Retrieved from http://www.telegrafo.com.ec/economia/item/cuatro-mil-familias-beneficiadas-con-laentrega-de-tierras.html

Diario El Universo. (2006, November 25). Las Ofertas de Rafael Correa. Diario El Universo. Guayaquil. Retrieved from http://www.eluniverso.com/2006/11/25/0001/8/BE47EF4C76874D59A1D2D559252 DC44B.html

Dietrich, H. (2009). The Advance of 21st Century Socialism in Latin America and Europe. In The Fourth Forum of the World Association for Political Economy. Presented at the Nation, State, and Democratic Governance of the Global Economy and Politics, Paris, France. Retrieved from http://www.wrpe.org/WAPE/WAPE\%20papers\%202009/DIETERICH.pdf

D-maps.com. (n.d.-a). República del Ecuador. D-maps.com - Mapas Gratuitos. Retrieved March 20, 2013, from http://www.d-maps.com/carte.php?num_car=38889\&lang=es

D-maps.com. (n.d.-b). América del Sur. D-maps.com - Mapas Gratuitos. Retrieved March 20, 2013, from http://www.d-maps.com/carte.php?num_car=28523\&lang=es

Domingo, P. (2005). Democracy and new social forces in Bolivia. Social Forces, 83(4), $1727-1743$.

Durning, D. (1993). Participatory policy analysis in a social service agency: A case study. Journal of Policy Analysis and Management, 12(2), 297-322.

ECLAC. (2009). Income Poverty and Unsatisfied Basic Needs (No. LC/MEX/L.949). Mexico: Economic Commission for Latin America and the Caribbean (ECLAC).

ECLAC. (n.d.-a). Annual Gross Domestic Product (AGD) by Expenditure at Current Prices in National Currency (CEPALSTAT Databases). Economic Commission for Latin America and the Caribbean. Retrieved from http://interwp.cepal.org/sisgen/ConsultaIntegrada.asp?idIndicador=2193\&idioma=i 
ECLAC. (n.d.-b). Ecuador: Exportación de los 10 Productos Principales Conforme a la CUCI rev.1, según Participación Porcentual en cada Año (CEPALSTAT Databases). Economic Commission for Latin America and the Caribbean. Retrieved from http://interwp.cepal.org/sisgen/ConsultaIntegrada.asp?idIndicador=1959\&idioma=e

ECLAC. (n.d.-c). Población, por Areas Urbana y Rural, según Sexo (CEPALSTAT Databases). Economic Commission for Latin America and the Caribbean. Retrieved from http://interwp.cepal.org/sisgen/ConsultaIntegrada.asp?IdAplicacion=1\&idTema=1\&id Indicador $=28 \&$ idioma $=\mathrm{e} \&$ accesointerno $=$ no

ECUARUNARI. (n.d.). Histroria. ECUARUNARI -Confederación Kichwa del Ecuador. Retrieved December 22, 2012, from http://ecuarunari.org/portal/info/historia

Eggens, L. (2012, March). We need to Convince Civil Society of the Urgency for a Radical Transformation. Farming Matters, 14-16.

Escobar, A. (2010). Latin America at a crossroads. Cultural Studies, 24(1), 1-65.

Espinel, R. (2010). Ruralidad y Soberanía Alimentaria en América Latina y el Caribe. Ecuador Debate, (79), 151-162.

FAO. (2003). Trade Reforms and Food Security: Conceptualizing the linkages. Rome: Food and Agricultural Organisation of the United Nations. Retrieved from ftp://ftp.fao.org/docrep/fao/005/y4671e/y4671e00.pdf

FENOCIN. (1999). Hacia el Nuevo Milenio - Porque en el Campo Está la Fuerza del DEsarrollo, de la Identidad y la Vida. Quito: Agriterra.

FENOCIN. (2008a, March 12). La Interculturalidad Busca la Integración de Ecuatorianos Boletín de Prensa. FENOCIN. Retrieved November 26, 2012, from http://www.fenocin.org/bol12marzointerculturalidad.html

FENOCIN. (2008b, October 4). Fenocin Expresa Respaldo a Correa y Defiende Propuesta de Interculturalidad. FENOCIN. Retrieved January 2, 2013, from http://www.fenocin.org/bol10abrilrespaldo.html

FENOCIN. (2010). Federación de Organizaciones Campesinas, Indígenas y Negras (FENOCIN). In Hacia la Soberanía Alimentaria: Agroecología y Comercio Asociativo desde Experiencias Andino-Amazónicas (1a. ed., pp. 133-168). Quito: Universidad Andina Simón Bolívar: Ediciones La Tierra: GTZ.

FENOCIN. (n.d.). ¿Quienes somos? FENOCIN. Retrieved December 12, 2012, from http://www.fenocin.org.ec/nosotros/iquienes-somos 
Fernández Kelly, M. P. (1994). Towanda's Triumph: Social and Cultural Capital in the Transition to Adulthood in the Urban Ghetto*. International Journal of Urban and Regional Research, 18(1), 88-111. doi:10.1111/j.1468-2427.1994.tb00252.x

Fundacion Interris-Balandra Cruz del Sur. (2009). Feria de Alimentos Orgánicos Bona Terra. Fundacion In Terris. Retrieved April 15, 2013, from

García, G. V. (2007). Maíz, Papas y Carroña: la "Identidad” Alimenticia del "Indio" de Huasipungo. Neophilologus, 92(1), 35-48. doi:10.1007/s11061-007-9058-8

García, J. E. (2007). Cultivos Genéticamente Modificados: las Promesas y las Buenas Intenciones no Bastan. Revista de biología tropical, 52(3), 727-732.

Garrido Peña, F. (2012). Ecología política y agroecología: Marcos cognitivos y diseño institucional. Agroecología, 6, 21-28.

Germani, G. (1969). Stages of modernization in Latin America. Studies in Comparative International Development (SCID), 5(8), 155-174. doi:10.1007/BF02800615

GIZ. (2011a). Agro biodiversidad y Soberanía Alimentaria en Comunidades Shuar de Morona Santiago: Análisis de impactos del Programa GESOREN-GIZ (Estudio de Impacto). Quito, Ecuador: GESOREN-GIZ. Retrieved from http://www.unl.edu.ec/agropecuaria/wp-content/uploads/2012/03/F04_SobAlim.pdf

GIZ. (2011b). La Mesa del Cacao Fino de Aroma de la Reserva de Biosfera Sumaco Análisis de Impactos del Programa GESOREN - GIZ. Quito, Ecuador.

Gobierno Autónomo Descentralizado Provincial de Napo. (2012, September 11). Tena. Gobierno Autónomo Descentralizado Provincial de Napo. Retrieved November 2, 2012, from http://www.napo.gob.ec/index.php/la-provincia/cantones

Gobierno Autónomo Descentralizado Provincial de Napo. (n.d.). División Política. Gobierno Autónomo Descentralizado Provincial de Napo. Retrieved November 2, 2012, from http://www.napo.gob.ec/index.php/la-provincia/division-politica

Gonzalez, C. G. (2012). Organismos Genéticamente Modificados (OGM) Y Justicia: Implicaciones De La Biotecnología Para La Justicia Ambiental Internacional. Revista Juridica Grado Cero (Universidad Nacional Autonoma de Mexico), 1, 13-84.

González de Molina, M. (2012). Algunas notas sobre agroecología y política. Agroecología, 6,9-21. 
Goodman, D., \& Goodman, M. K. (2009). Food Networks, Alternative. International Encyclopedia of Human Geographhy, 208-220.

Gregory, J., Hartz-Karp, J., \& Watson, R. (2008). Using deliberative techniques to engage the community in policy development. Australia and New Zealand Health Policy, 5(1), 16. doi:10.1186/1743-8462-5-16

Grimes, J. (2009). Rediscovering the Cacao in Ecuador's Upper Napo River Valley. Focus on Geography, 51(4), 23-30.

Grinspun, R. (2008). Explorando las conexiones entre el comercio global, la agricultura industrial y el subdesarrollo rural. In L. North \& J. D. Cameron (Eds.), Desarrollo rural y neoliberalismo : Ecuador desde una perspectiva comparativa (1st Edition., pp. 63-86). Quito, Ecuador: Corporación Editora Nacional : Universidad Andina Simón Bolívar, Sede Ecuador.

Guerrero, R. (2008). Descentralización, Autonomía y Regionalización. In Análisis Nueva Constitución (pp. 226-243). Quito, Ecuador: ILDIS-Friedrich Ebert Stiftung-Revista La tendencia.

Guzmán, G., \& González de Molina, M. (2006). Sobre las Posibilidades de Crecimiento Agrario en los Siglos XVIII, XIX y XX. Un Estudio de Caso desde la Perspectiva Energética. Historia Agraria, 40, 437-470.

Harding, S. (1993). Rethinking Standpoint Epistemology: What is "Strong Objectivity"? In L. Alcoff \& E. Potter (Eds.), Feminist epistemologies. New York: Routledge.

Heron, J., \& Reason, P. (2001). The Practice of Co-Operative Inquiry: Research with rather than on People. In P. Reason \& H. Bradbury (Eds.), Handbook of Action Research: Participative Inquiry and Practice (pp. 179-188). London: SAGE Publications Limited. Retrieved from http://books.google.com/books?hl=es\&lr=\&id=v5TQfaZqZxEC\&oi=fnd\&pg=PR9\&d $\mathrm{q}=\% 22 \mathrm{handbook}+$ of + action+research $\% 22 \&$ ots=TtOJMbH0Im\&sig=PhXkSkV206Vo NJZ1WP7_9pNFBYg

Herrera, S. (2009, June 30). Debate y Acciones sobre Desarrollo Rural en Ecuador. Instituto para El Desarrollo Rural de Sudamérica - IPDRS. Retrieved from http://www.sudamericarural.org/nuestra-produccion/dialogos/16?view=dialogos

Hirshberg, M. C. (2010). The romance of good deeds: a business with a cause can do good in the world. It can also be great for your marriage.(BALANCING ACTS). Inc, 32(10), 47. 
Holt-Giménez, E. (2009). From Food Crisis to Food Sovereignty.: The Challenge of Social Movements. Monthly review, 61(3), 142-156.

IFPRI. (2002). Green Revolution: Curse Or Blessing? Internat. Food Policy Research Inst.

INEC. (2000). III Censo Nacional Agropecuario. Instituto Nacional de Estadísticas y Censos Ecuador - INEC. Retrieved from

http://www.inec.gob.ec/estadisticas/?option=com_content\&view=article\&id=111\&Ite $\operatorname{mid}=126$

INEC. (2001). Censo de Población y Vivienda 2001 (Census). Ecuador: Instituto Nacional de Estadísticas y Censos - INEC. Retrieved from

http://www.inec.gob.ec/lector_archivos/ver.php?p=cpv\&a=censos_nacionales\&b=cen so_poblacion_vivienda_2001\&c=bases_datos_spss

INEC. (2008). Ecuador: La desnutrición en la Población Indígena y Afroecuatoriana Menor de cinco Años (Analisis Sociodemográfico). INEC.

INEC. (2010). Resultados Censo de Población. Instituto Nacional de Estadísticas y Censos INEC. Retrieved May 5, 2013, from http://www.inec.gob.ec/cpv/

INEC. (2012). Indicadores Pobreza Diciembre 2012. Instituto Nacional de Estadísticas y Censos - INEC. Retrieved from

http://www.inec.gob.ec/estadisticas/index.php?option=com_remository\&Itemid=\&fun $\mathrm{c}=$ startdown\&id=1694\&lang=es\&TB_iframe=true \&height $=250 \&$ width $=800$

INEC. (n.d.). Pobreza. Instituto Nacional de Estadísticas y Censos (INEC). Retrieved March 2, 2013, from

http://www.inec.gob.ec/estadisticas/?option=com_content\&view=article\&id=65\&Item $\mathrm{id}=35$

Intriago, R. (n.d.). FECAOL. The Permacyclists Project. Interview. Retrieved April 1, 2013, from http://www.permacyclists.com/lang/es/projets-projects-2/fecaol/

IPCC. (2007). Climate Change 2007: Synthesis Report Summary for Policymakers. IPCC. Retrieved from http://www.ipcc.ch/publications_and_data/ar4/syr/en/spm.html

Ishii-Eiteman, M., \& Patel, R. (2009). Food sovereignty and the international assessment of agricultural knowledge, science and technology for development. Journal of Peasant Studies, 36(3), 689-700.

IWGIA. (n.d.). Indigenous Peoples in Latin America - A General Overview. International Work Group for Indigenpus Affairs. Retrieved April 15, 2013, from http://www.iwgia.org/regions/latin-america/indigenous-peoples-in-latin-america 
Jalil, L. (2009, September 3). Getting Food Sovereignty and Women's Rights onto the Political Agenda. Leisa Magazine, (25). Retrieved from http://www.agriculturesnetwork.org/magazines/global/women-and-foodsovereignty/getting-food-sovereignty-and-womens-rights-onto

Jones, C. (2012). Weaving Niche Production into Pacific Economies - The Social, Economic and Environmental Impacts of Fiji Water on Local communities (Masters of Development Studies). Victoria University of Wellington, Wellington.

Kallari. (n.d.-a). The Best Chocolate on Earth. Kallari Chocolate. Retrieved November 17, 2012, from http://kallari.com/chocolate.html

Kallari. (n.d.-b). The Kallari Association. Kallari Chocolate. Retrieved November 29, 2012, from http://kallari.com/

Kay, C. (1995). Desarrollo rural y cuestiones agrarias en la América Latina contemporánea. Agricultura y sociedad, (75), 27-82.

Kitchin, R., \& Tate, N. J. (2000). Conducting research in human geography: theory, methodology and practice. Harlow: Prentice Hall.

Knapp, G., \& Herlihy, P. (2002). Mapping the Landscape of Identity. Yearbook. Conference of Latin Americanist Geographers, 27, 251-268. doi:10.2307/25765909

Korovkin, T. (2002). Comunidades Indígenas, Economía de Mercado y Democracia en los Andes Ecuatorianos. Quito: Centro de Investigaciones de los Movimientos Sociales del Ecuador: IFEA : ABYA YALA.

Korovkin, T. (2008). La Reforma Agraria y las Comunidades Indígenas Campesinas en Chimborazo. In L. North \& J. D. Cameron (Eds.), Desarrollo rural y neoliberalismo : Ecuador desde una perspectiva comparativa (1st Edition., pp. 165-180). Quito, Ecuador: Corporación Editora Nacional : Universidad Andina Simón Bolívar, Sede Ecuador.

La Via Campesina. (2011, February 9). The International Peasant's Voice. La Via Campesina - International Peasant's Movement. Retrieved January 17, 2013, from http://viacampesina.org/en/index.php/organisation-mainmenu-44/what-is-la-viacampesina-mainmenu-45/1002-the-international-peasants-voice27

Larach, M. A. (2001). Trade in transgenic products: a review of the international debate. ECLAC Review, 201-216. 
Larrea, C. (2008). Tenencia de la Tierra, Cambios Agrarios y Etnicidad Indígena en el Ecuador: 1954-2000. In J. D. Cameron \& L. North (Eds.), Desarrollo rural y neoliberalismo: Ecuador desde una perspectiva comparativa (1st Edition in Spanish.). Quito, Ecuador: Corporación Editora Nacional : Universidad Andina Simón Bolívar, Sede Ecuador.

Larrea, C. (2010). La estructura social ecuatoriana: 1982-2009. Retrieved from http://www.repositorio.uasb.edu.ec/handle/10644/860

Larrea, C. (n.d.). Yasuni-ITT: An Initiative to Change History. (R. Huber, Trans.) Yasuni ITT. Retrieved October 6, 2012, from http://yasuni-itt.gob.ec/espanol/trust-fund-terms-ofreference/

Larrea, C., Landín, R., Larrea, A. I., Wrborich, W., \& Fraga, R. (2008). Mapas de pobreza, consumo por habitante y desigualdad social en el Ecuador: 1995-2006. Metodología y resultados. Documento de trabajo, (13). Retrieved from http://gisweb.ciat.cgiar.org/website/googleearth/POVERTY/ECU/DOCUMENTATIO N/Larrea,\%20Carlos, \%20\%202008.\%20Mapas\%20de\%20pobreza,\%20consumo\%20p or\%20habitante\%20y\%20desigualdad\%20social\%20en\%20el\%20Ecuador\%2019952006.pdf

Larrea Maldonado, ana M. (2008). La Plurinacionalidad: Iguales y Diversos en Busca del "Sumak Kawsay." In Seminario Regional Andino - Democracia, Interculturalidad, Plurinacionalidad y Desafíos para la Integración Andina. Presented at the Estado Plurinacional y Construcción de una Democracia Intercultural, La Paz, Bolivia: CEBEM. Retrieved from http://www.cebem.org/cmsfiles/publicaciones/Memorias_del_seminario.pdf

Lawn, P. A. (2003). A theoretical foundation to support the Index of Sustainable Economic Welfare (ISEW), Genuine Progress Indicator (GPI), and other related indexes. Ecological Economics, 44(1), 105-118.

León, M. (2008). El Buen Vivir: Objetivo y Camino para Otro Modelo. In Análisis Nueva Constitución (pp. 136-151). Quito, Ecuador: ILDIS-Friedrich Ebert Stiftung-Revista La tendencia.

Lipton, M. (2009). Land reform in developing countries : property rights and property wrongs. London; New York: Routledge.

Lipton, M., \& Ravallion, M. (1995). Poverty and Policy (Chapter 41). In J. Behrman \& T. N. Srinivasan (Eds.), Handbook of development economics Vol. 3B (Vol. 3B, pp. 25512657). Amsterdam: Elsevier. 
Losey, J. E., \& Vaughan, M. (2006). The economic value of ecological services provided by insects. Bioscience, 56(4), 311-323.

Low, W., \& Davenport, E. (2005). Has the medium (roast) become the message?: The ethics of marketing fair trade in the mainstream. International Marketing Review, 22(5), 494-511. doi:10.1108/02651330510624354

Lu, Y., Wu, K., Jiang, Y., Xia, B., Li, P., Feng, H., ... Guo, Y. (2010). Mirid Bug Outbreaks in Multiple Crops Correlated with Wide-Scale Adoption of Bt Cotton in China. Science, 328(5982), 1151-1154. doi:10.1126/science.1187881

Lyon, S. (2006). Evaluating fair Trade Consumption: Politics, Defetishization and Producer Participation. International Journal of Consumer Studies, 30(5), 452-464. doi:10.1111/j.1470-6431.2006.00530.x

Macas, L. (2011). El Sumak Kawsay. Decrecimiento y Buen Vivir. Retrieved October 10, 2012, from http://decrecimientoybuenvivir.files.wordpress.com/2011/01/sumakkawsay-luis-macas.pdf

MAELA. (n.d.). Quienes Somos - Presentación. Movimiento Agroecológico Latinoamericano. Retrieved January 24, 2013, from http://www.maela-agroecologia.org/quienessomos/article/presentacion

MAGAP. (2012). Informe Período 2011 (Annual Report). Programa Nacional de Innovación Tecnológica Participativa y Productividad Agrícola (MAGAP).

MAGAP Ecuador. (2012, September 24). MAGAP entrega urea subsidiada a pequeños agricultores de Cañar. Ministerio de Agricultura, Ganaderia, Acuacultura y PescaNotcias. Retrieved December 10, 2012, from http://www.agricultura.gob.ec/magapentrega-urea-subsidiada-a-pequenos-agricultores-de-canar/

MAGAP Ecuador. (2013, September 1). Se agilita la entrega de la urea subsidiada. Ministerio de Agricultura, Ganaderia, Acuacultura y Pesca - Notcias. Retrieved January 15, 2013, from http://www.agricultura.gob.ec/se-agilita-la-entrega-de-la-urea-subsidiada/

Martínez, L. (2008). Respuestas Endógenas de los Campesinos frente al Ajuste Estructural. Ecuador desde una Perspectiva Andina Comparativa. In L. North \& J. D. Cameron (Eds.), Desarrollo rural y neoliberalismo : Ecuador desde una perspectiva comparativa (1st ed., pp. 105-127). Quito, Ecuador: Corporación Editora Nacional : Universidad Andina Simón Bolívar, Sede Ecuador.

Martínez, R. (2005). Hambre y desigualdad en los países andinos: la desnutrición y la vulnerabilidad alimentaria en Bolivia, Colombia, Ecuador y Perú. (UN. ECLAC. Social Development Division, Ed.). Santiago: Naciones Unidas, CEPAL. 
McDonell, S. (n.d.). Our Story. Applegate - Organic \& Natural Meats. Retrieved November 27, 2012, from http://www.applegate.com/our-story

McMichael, P. (2008). Development and Social Change: a Global Perspective (4th ed.). Thousands Oaks, CA: Pine Forge, Sage. Retrieved from http://search.informit.com.au/documentSummary; $\mathrm{dn}=414025602971224$;res=IELBus

McMichael, P. (2009). Food Sovereignty, Social Reproduction and the Agrarian Question. In A. H. Akram-Lodhi \& C. Kay (Eds.), Peasants and Globalization: Political Economy, Rural Transformation and the Agrarian Question (pp. 288-311). London ; New York: Routledge.

Meehan, M. (2010). Literature Review: Food Sovereignty - A Global Movement. Centro Ashé. Retrieved January 20, 2013, from http://www.centroashe.org/history-oftalamanca-costa-rica.html

Melo, C. J. (2010). Left Behind: A Farmer's Fate in the Age of Sustainable Development (Paper 331). FIU Electronic Theses and Dissertations. Retrieved from http://digitalcommons.fiu.edu/etd/331

Mrs María. (2012, May). Personal Communication.

Murray, W. (2008). Neoliberalism, Rural Underdevelopment Geography and the Global South, 1(1), 33-38.

Murray, W. (2010). From Commodities to Place-Based Niche Products: Making Globalised Places in Asia and the Pacific. In International Conference for Sustainable Greater Mekong Subregion. Bangkok.

Murray, W. E. (2006). Geographies of Globalization. London ; New York: Routledge.

Murray, W. E. (2009). Neoliberalism and Development. In (R. Kitchin \& N. J. Thrift, Eds.)International Encyclopedia of Human Geography. London: Routledge.

Murray, W. E., \& Overton, J. (2003). Designing Development Research. In R. Scheyvens \& D. Storey (Eds.), Development fieldwork a practical guide (pp. 17-35). London: SAGE. Retrieved from http://public.eblib.com/EBLPublic/PublicView.do?ptiID=254635

Nesto, B. (2010). Discovering Terroir in the World of Chocolate. Gastronomica - The Journal of Food and Culture, 10(1), 131-135. 
Nicholls, C. I., \& Altieri, M. (2012). Modelos Ecológicos y Resilientes de Producción Agrícola para el Siglo XXI. (J. M. Egea, J. Tello, \& M. Altieri, Eds.)Agroecologia, 6, 29-37.

North, L., Kit, W., \& Koep, R. (2008). Conflictos por Tierras Rurales y Violación de Derechos Humanos en Ecuador. In L. North \& J. D. Cameron (Eds.), Desarrollo rural y neoliberalismo : Ecuador desde una perspectiva comparativa (1st Edition., pp. 147164). Quito, Ecuador: Corporación Editora Nacional : Universidad Andina Simón Bolívar, Sede Ecuador.

OECD. (2001, November 12). GVA. Glossary of Statistical Terms. Retrieved February 2, 2012, from http://stats.oecd.org/glossary/detail.asp?ID=1184

OECD. (2006, February 16). Gini Index. Glossary of Statistical Terms. Retrieved October 2, 2012, from http://stats.oecd.org/glossary/detail.asp?ID=4842

Ortiz Davidson, J., Ortiz Mendoza, E., \& Cárdenas Almagro, A. (2004). Revisión del Debate Sobre la Pobreza, Orientado al Diseño de Políticas. Análisis Económico, XIX(42). Retrieved from http://www.analisiseconomico.com.mx/pdf/4213.pdf

Overton, J. (2010). Places, Products and Sustainable Rural Development: Geographical Indications and Niche Marketing. In International Conference for Sustainable Greater Mekong Subregion. Bangkok.

Patel, R. (2009). Food sovereignty. Journal of Peasant Studies, 36(3), 663-706. doi:10.1080/03066150903143079

Paz y Miño, J., \& Pazmiño, D. (2008). La Plurinacionalidad en la nueva Constitución. In Análisis Nueva Constitución (pp. 26-44). Quito, Ecuador: ILDIS-Friedrich Ebert Stiftung-Revista La tendencia.

Perreault, T. (2003). Social Capital, Development, and Indigenous Politics in Ecuadorian Amazonia. Geographical Review, 93(3), 328-349.

Perreault, T. (2005). Why Chacras (Swidden gardens) Persist: Agrobiodiversity, Food Security, and Cultural identity in the Ecuadorian Amazon. Human Organization, 64(4), 327-339.

Petersen, P. (2012, June). Agricultural MEtabolism as a Tool. Farming Matters. Retrieved from http://www.agriculturesnetwork.org/magazines/global/rio-20-specialissue/interview-manuel-gonzalez-de-molina 
Petras, J. F. (2008). Latin America's Changing Mosaic: Movements in Flux and Center-Left Governments in Power. Theomai: estudios sobre sociedad, naturaleza y desarrollo, (17), 10 .

Petras, J., \& Veltmeyer, H. (2001). Are Latin American peasant movements still a force for change? Some new paradigms revisited. Journal of Peasant Studies, 28(2), 83-118. doi:10.1080/03066150108438767

Pieterse, J. N. (1998). My Paradigm or Yours? Alternative Development, Post-Development, Reflexive Development. Development and Change, 29(2), 343-373. doi:10.1111/1467-7660.00081

Postero, N. G., \& Zamosc, L. (Eds.). (2004). The struggle for indigenous rights in Latin America. Brighton [England]; Portland, Or.: Sussex Academic Press.

Pozo, C. (2012, August). Personal Communication.

Prada, F. (2005). Diversidad Ecológica y Descentralización Política: Territorialidad Indígena, Estado Nacional, Petróleo y Biotecnología. In L. E. López \& P. Regalsky (Eds.), Movimientos indígenas y Estado en Bolivia (1. ed., pp. 145-188). La Paz, Bolivia: PROEIB Andes : CENDA : Plural Editores.

Presidencia de la República del Ecuador. (n.d.). Gabinete de la Revolución Ciudadana. Presidencia de la República del Ecuador. Retrieved April 7, 2013, from http://www.presidencia.gob.ec/gabinete-de-la-revolucion-ciudadana/

Raymond, R. (2012). Improving Food Systems for Sustainable Diets in a Green Economy. In Greening the Economy with Agriculture (pp. 185-241). Rome: FAO.

Renard, M.-C. (2005). Quality Certification, Regulation and Power in Fair Trade. Journal of Rural Studies, 21(4), 419-431. doi:10.1016/j.jrurstud.2005.09.002

Robson, C. (2002). Real world research: A resource for social scientists and practitionerresearchers (2nd ed.). Malden: Blackwell Oxford. Retrieved from http://media.matthewsbooks.com.s3.amazonaws.com/documents/tocwork/063/978063 1213055.pdf

Rosset, P. (2003). Food sovereignty: global rallying cry of farmer movements. Institute for Food and Development Policy, Food First Backgrounder, 9(4), 1-4.

RP-AC-1. (2012, May). Personal Communication.

RP-CFS-1. (2012, May). Personal Communication.

RP-FA-1. (2012, July). Personal Communication. 
RP-FA-2. (2012, May). Personal Communication.

RP-FA-3. (2012, July). Personal Communication.

RP-FA-4. (2012, August). Personal Communication.

RP-FA-5. (2012, May). Personal Communication.

RP-FEN-1. (2012, July). Personal Communication.

RP-FEN-2. (2012, July). Personal Communication.

RP-FEN-3. (2012, July). Personal Communication.

RP-KAL-1. (2012, August). Personal Communication.

RP-KAL-2. (2012, August). Personal Communication.

RP-MA-1. (2012, May). Personal Communication.

RP-MA-2. (2012, May). Personal Communication.

RP-MA-3. (2012, June). Personal Communication.

RP-NGO-1. (2012, June). Personal Communication.

RP-NGO-2. (2012, May). Personal Communication.

RP-NGO-3. (2012, May). Personal Communication.

RP-NGO-4. (2012, May). Personal Communication.

RP-NGO-5. (2012, August). Personal Communication.

RP-PG-1. (2012, June). Personal Communication.

RP-PG-2. (2012, June). Personal Communication.

Salgado, W. (2012, May). Personal Communication. 
Sánchez, J. (2006). Inequality, Ethnicity and Social Disorder: The Ecuadorian Case. In Third World Bank Conference on Inequality (Vol. 5). Retrieved from http://siteresources.worldbank.org/INTDECINEQ/Resources/11492081147789289867/IIIWB_Conference_Inequality_Ethnicity_and_Social_Disorder.pdf

Sánchez Parga, J. (2007). El movimiento indígena ecuatoriano: la larga ruta de la comunidad al partido. Quito, Ecuador: Centro Andino de Acción Popular.

Santopietro, J. (2008, November 5). When Chocolate Is a Way of Life. The New York Times. Retrieved from http://www.nytimes.com/2008/11/05/dining/05choc.html

Scheyvens, R., Nowak, B., \& Scheyvens, H. (2003). Ethical Issues. In R. Scheyvens \& D. Storey (Eds.), Development fieldwork a practical guide (pp. 139-166). London: SAGE. Retrieved from http://public.eblib.com/EBLPublic/PublicView.do?ptiID=254635

SENPLADES. (n.d.). Presentacion. Plan Nacional del Buen Vivir. Retrieved May 1, 2013, from http://plan.senplades.gob.ec/presentacion;jsessionid=46115BD40C37ED25DF2B2C18 675A5CC3.nodeaplan

Shiva, V. (2004). Earth Democracy: Creating living economies, living democracies, living cultures. South Asian Popular Culture, 2(1), 5-18. doi:10.1080/1474668042000210483

Shiva, V. (2005a). NEW EMPERORS, OLD CLOTHES. The Ecologist, 35(6), 22.

Shiva, V. (2005b). Earth democracy: justice, sustainability, and peace. Cambridge, Mass: South End Press.

SOCLA. (n.d.). SOCLA in English. Sociedad Cientifica LatinoAmericana de Agroecologia (SOCLA). Retrieved January 24, 2013, from http://agroeco.org/socla/socla_in_english.html

Solo de Zaldívar, V. B. (2008a). Las Contradicciones de las ONG de Desarrollo Rural. La Trayectoria del FEPP en Chimborazo, 1981-2000. In L. North \& J. D. Cameron (Eds.), Desarrollo rural y neoliberalismo : Ecuador desde una perspectiva comparativa (1st Edition., pp. 181-203). Quito, Ecuador: Corporación Editora Nacional : Universidad Andina Simón Bolívar, Sede Ecuador. 
Solo de Zaldívar, V. B. (2008b). De la Ventriloquia a la Etnofagia o la Etnización del Desarrollo Rural en los Andes Ecuatorianos. In Intelectuales, Mediadores y Antropólogos, la Traducción y la Reinterpretación de lo Global en lo Local (Vol. 7, pp. 113-136). Presented at the XI Congreso de Antropología de la FAAEE, Ankulegi Antropologia Elkartea. Retrieved from http://dialnet.unirioja.es/servlet/articulo?codigo=3081812

Souris, M. (n.d.). Ecuador. Dr. Marc Souris. GIS data, compiled and constructed by IRD/MS with SavGIS. Retrieved May 28, 2013, from http://www.savgis.org/ecuador.htm

Springer-Heinze, A. (n.d.). Value Chains. GIZ - Deutsche Gesellschaft für Internationale Zusammenarbeit GmbH. Retrieved December 15, 2012, from http://www.giz.de/Themen/en/33352.htm

Stake, R. E. (2003). Case Studies. In N. K. Denzin \& Y. S. Lincoln (Eds.), Strategies of qualitative inquiry (2nd ed., pp. 134-164). London: Sage.

Stern, N. (2006). The economics of climate change: the Stern review. Cambridge University Press. Retrieved from http://www.hm-treasury.gov.uk/stern_review_report.htm

Stiglitz, J. E., Sen, A., \& Fitoussi, J. P. (2009). Report by the Commission on the Measurement of Economic Performance and Social Progress. Commission on the Measurement of Economic Performance and Social Progress. Retrieved from www. stiglitz-senfitoussi. fr/documents/rapport_anglais. pdf

Streeten, P., \& Burki, S. J. (1978). Basic needs: Some issues. World Development, 6(3), 411 421. doi:10.1016/0305-750X(78)90116-X

Takacs, D. (2003). How Does Your Positionality Bias Your Epistemology? Thought \& Action, 19(1), 27-38.

Tamayo, A. (2009). La agricultura orgánica y la agricultura tradicional: una alternativa intercultural (Investigación). Letras Verdes, 4. Retrieved from http://www.flacsoandes.org/dspace/handle/10469/897

Tauli-Corpuz, V. (2010). Introduction. In Tebtebba (Organization) (Ed.), Towards an alternative development paradigm: indigenous people's self-determined development (pp. xiii-xxi). Baguio City, Philippines: Tebtebba Foundation.

TEBB. (2010). The Economics of Ecosystems and Biodiversity: Mainstreaming the Economics of Nature: A Synthesis of the Approach, Conclusions and Recommendations of TEBB. 
Thurow, L. C. (1967). The Causes of Poverty. The Quarterly Journal of Economics, 81(1), 39-57. doi:10.2307/1879672

Toledo, V. M. (2012). LA AGROECOLOGIA EN LATINOAMERICA: TRES REVOLUCIONES, UNA MISMA TRANSFORMACION. INDICE VOLUMEN 6, 6, $37-46$.

Torremocha, E. (2012). LOS SISTEMAS PARTICIPATIVOS DE GARANTÍA. HERRAMIENTAS DE DEFINICIÓN DE ESTRATEGIAS AGROECOLÓGICAS. (J. M. Egea, J. Tello, \& M. Altieri, Eds.)Agroecologia, 6, 89-96.

Townsend, P. (1971). Conceptualising Poverty, the International Analysis of Poverty. London: Harvester Wheatsheaf.

Townsend, P. (1993). The International Analysis of Poverty. London: Harvester Wheatsheaf.

Underdal, A. (2010). Complexity and Challenges for Long-term Environmental Governance. Global Environmental Change, 20, 386-393.

Valarezo, S. J. A. (2002). La selva, los pueblos, su historia: mitos, leyendas, tradiciones y fauna de la amazonía ecuatoriana (1ra. ed.). Quito, Ecuador: Misión Josefina de Napo : Instituto Para el Ecodesarrollo Regional Amazónico : CODENPE, PRODEPINE.

Van den Bergh, J. C. J. M. (2009). The GDP paradox. Journal of Economic Psychology, $30(2), 117-135$.

Van den Berghe, P. L. (1992). Education, Class and Ethnicity in Southern Peru:

Revolutionary Colonialism. In P. G. Altbach \& G. P. Kelly (Eds.), Education and the Colonial Experience (2nd Revised Edition.). New York: Advent Books.

Vaudour, E. (2002). The Quality of Grapes and Wine in Relation to Geography: Notions of Terroir at Various Scales. Journal of Wine Research, 13(2), 117-141. doi:10.1080/0957126022000017981

Veiga, J. ., Tourrand, J. F., Poccard-Chapuis, R., \& Piketty, M. . (2003). Cattle Ranching in the Amazon Rainforest. In XII World Forestry Congress. Québec, Canada. Retrieved from http://www.fao.org/docrep/ARTICLE/WFC/XII/0568-B1.HTM

Vera, R. (2003, January). Country Pasture/Forage Resource Profiles - Ecuador. Food and Agriculture Organization of the United Nations - FAO. Retrieved October 15, 2012, from http://www.fao.org/ag/AGP/AGPC/doc/Counprof/Ecuador/ecuador.htm 
Vicente, Á., Arqués, J. F., Villalbí, J. R., Centrich, F., Serrahima, E., Llebaria, X., \& Casas, C. (2004). Plaguicidas en la dieta: aportando piezas al rompecabezas. Gaceta Sanitaria, 18(6), 425-430.

Waterman, P. (2007). The Bamako Appeal - Back to the Future? (H. Melber, Ed.)Critical Currents - Dag Hammarskjöld Foundation Occasional Paper Seires, 1, 53-59.

Watson, R. (2008). How to Assist the Small-Scale Farmer. In Achieving Sustainable Development and Promoting Development Cooperation: Dialogues at the Economic and Social Council. New York: United Nations.

Welch, C. A. (2012). Resisting Land Grabbing in Latin America during the Cold War and Globalization Eras. Presented at the International Conference on Global Land Grabbing II, Ithaca, NY: Land Deals Politics Initiative (LDPI). Retrieved from http://www.cornell-landproject.org/download/landgrab2012papers/welchfin.pdf

Wezel, A., Bellon, S., Doré, T., Francis, C., Vallod, D., \& David, C. (2009). Agroecology as a science, a movement and a practice. A review. Agronomy for Sustainable Development, 29(4), 503-515. doi:10.1051/agro/2009004

Wezel, A., \& Soldat, V. (2009). A quantitative and qualitative historical analysis of the scientific discipline of agroecology. International Journal of Agricultural Sustainability, 7(1), 3-18. doi:10.3763/ijas.2009.0400

Wiener Bravo, E. (2011). The Concentration of Land Ownership in Latin America: An approach to Current Problems. CISEPA : CIRAD : International Land Coalition. Retrieved from http://www.landcoalition.org/sites/default/files/publication/913/LA_Regional_ENG_w eb_11.03.11.pdf

Windfuhr, M., \& Jonsén, J. (2005). Food Sovereignty: towards democracy in localized food systems. Intermediate Technology.

Winter, M. (2004). Geographies of Food: Agro-Food Geographies-Farming, Food and Politics. Progress in Human Geography, 28(5), 664-670.

Wittman, H. (2009). Interview: Paul Nicholson, La Via Campesina. Journal of Peasant Studies, 36(3), 676-682.

World Bank. (1994). Indigenous people and poverty in Latin America: an empirical analysis. (G. Psacharopoulos \& H. A. Patrinos, Eds.). Washington, D.C: World Bank. 
World Bank. (2011). Latin America \& Caribbean | Data. The World Bank - Working for a World Free of Poverty. Retrieved January 24, 2013, from http://data.worldbank.org/region/latin-america-and-caribbean

Yashar, D. J. (2005). Contesting Citizenship in Latin America: The Rise of Indigenous Movements and the Postliberal Challenge. Cambridge; New York: Cambridge University Press.

Yasuni-ITT. (n.d.). Yasuni-ITT: An Initiative to Change History. Retrieved from http://yasuni-itt.gob.ec/espanol/trust-fund-terms-of-reference/

Yin, R. K. (2011). Qualitative research from start to finish. New York: Guilford Press. 